\title{
SHRINKAGE \& MODULUS OF ELASTICITY IN CONCRETE WITH RECYCLED AGGREGATES
}

\author{
A Thesis \\ presented to \\ the Faculty of California Polytechnic State University, \\ San Luis Obispo
}

In Partial Fulfillment

of the Requirements for the Degree of

Master of Science in Civil and Environmental Engineering

by

Brett Michael Schoppe

April 2011 
(C) 2011

BRETT MICHAEL SCHOPPE

ALL RIGHTS RESERVED 


\section{Committee Membership}

TITLE:

AUTHOR:

DATE SUBMITTED:

COMMITTEE CHAIR:

Daniel C. Jansen, Associate Professor

COMMITTEE MEMBER: Charles Chadwell, Associate Professor

COMMITTEE MEMBER: Ashraf Rahim, Associate Professor
Shrinkage \& Modulus of Elasticity in Concrete with

Recycled Aggregates

Brett Michael Schoppe

April 2011 


\begin{abstract}
Shrinkage \& Modulus of Elasticity in Concrete with Recycled Aggregates Brett Michael Schoppe
\end{abstract}

This paper presents results on experimental research for concrete produced using recycled coarse aggregates (RCA). Five types of coarse aggregates were used in this study, four of which were RCA. The main purpose of this research was to examine how different types and properties of coarse aggregate affected compressive strength, modulus of elasticity, and shrinkage in concrete when natural coarse aggregates were replaced with RCA. Concrete batches were made with water-cement $(\mathrm{w} / \mathrm{c})$ ratios of $0.30,0.45$, and 0.60 , and substitution percentages ranged from $0 \%$ to $100 \%$ of natural aggregate with RCA. Test results clearly show that compressive strength, modulus of elasticity, and shrinkage greatly depend on the quality and type of coarse aggregate used. In addition to testing of hardened concrete, predictive models for elasticity and ultimate shrinkage were developed to formulate and reinforce proposed conclusions about the properties and performance for the different RCA.

Keywords: Shrinkage, Compressive Strength, Modulus of Elasticity, Recycled Aggregates, Recycled Concrete. 


\section{Acknowledgements}

This project would not have been possible without the time and dedication received from my advisor, Dr. Jansen. I cannot thank him enough for his continual patience through my exploration of different topics. His shared enthusiasm for my topic only drove me to work harder and explore my topic in greater detail. I greatly appreciate all the hours he dedicated to making my research topic of choice possible.

Additionally, this investigation would have proven difficult without the extensive collection of laboratory equipment at California Polytechnic State University. Cal Poly's "Learn-by-Doing" attitude could not have been any truer for this particular study.

I would also like to thank my employer, Kevin Devaney, and co-worker, Chris Murphy, at Matrix Consulting Engineers for being so understanding of my experimental research schedule which often required impromptu time off from work.

Additional thanks are extended to fellow graduate students Paul Gordon, Victor Sherby, Ryan Sandstrom, Gary Welling, Greg Stone, David Bland, Brad Sterling and all others who took time out of their own studies to help with making concrete or preparing recycled aggregates. I cannot imagine how much more difficult things would have been without all of your help.

To my family, I thank you for showing me that there is life outside of school, and without which I could not have been successful in the first place. Thank you for all your love and support over the years.

Last, and certainly not least, I would like to thank my fiancée Becky. Throughout everything, your uplifting attitude and cheerfulness always brighten my day. Your love and dedication have no equal, and for that I will be forever grateful. 


\section{Table of Contents}

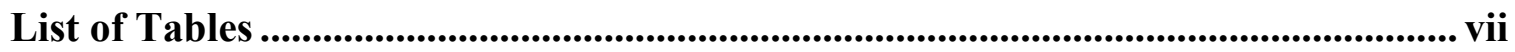

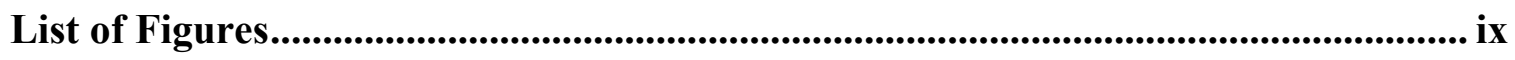

Chapter 1 Introduction................................................................................................ 1

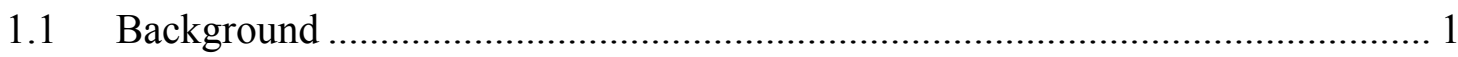

1.2 Research Significance ............................................................................ 2

Chapter 2 Experimental Procedure ...................................................................... 4

2.1 Concrete Materials ................................................................................... 4

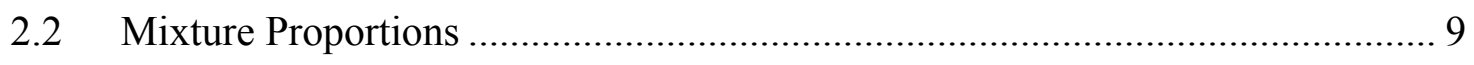

2.3 Concrete Specimens ............................................................................ 11

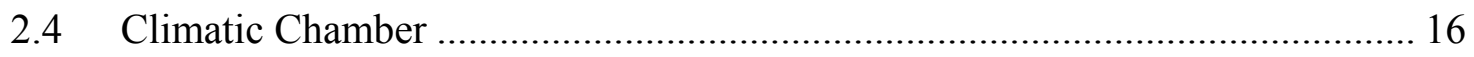

Chapter 3 Analytical Investigation................................................................................. 19

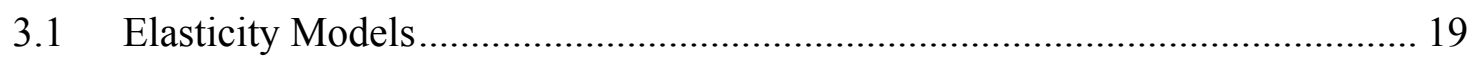

3.2 Ultimate Shrinkage Prediction Models ..................................................... 22

Chapter $4 \quad$ Experimental Results..................................................................................... 27

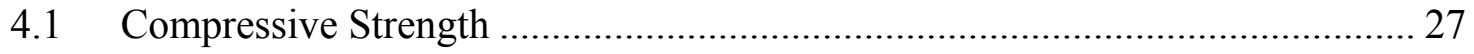

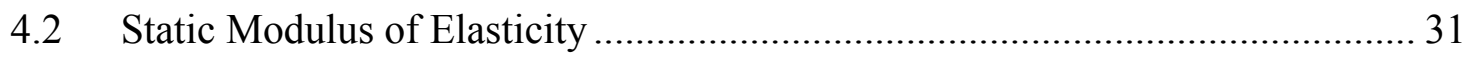

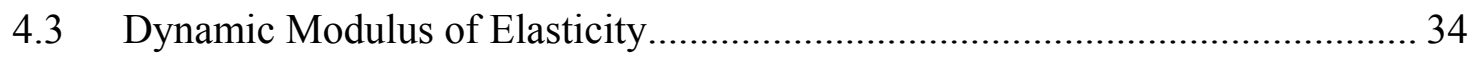

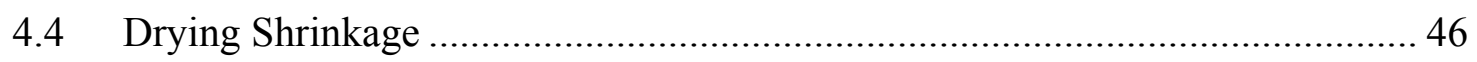

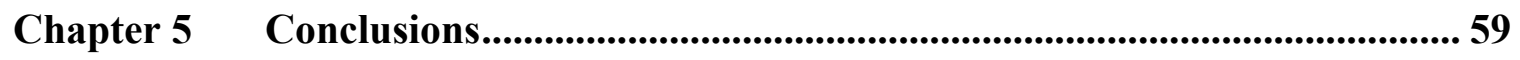

References........................................................................................................................................ 63

Appendix A Batch Records ................................................................................. 69

Appendix B Prismatic Beam Records .......................................................................... 90

Appendix C Shrinkage Curves .................................................................................. 110 


\section{List of Tables}

Table 2-1: Bulk Specific Gravity (BSG) and Absorption of Aggregates .................... 6

Table 2-2: Details of Concrete Mixes ................................................................................. 9

Table 3-1: Example of Least Squares Analysis for ACI209R-92 (R45-100)............. 24

Table 4-1: Summary of Compressive Strength $\left(f^{\prime}\right)$ and Modulus of Elasticity

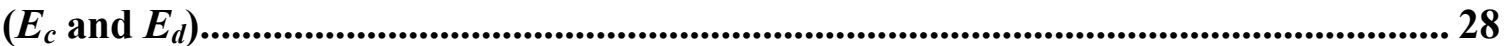

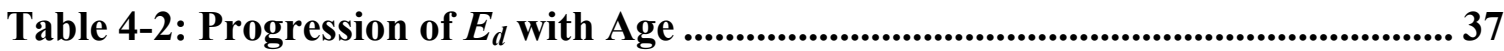

Table 4-3: Prediction of Ultimate Shrinkage $\left(S_{u l t}\right.$ and $\left.\varepsilon_{s h \infty}\right)$ Using ACI-209R-92

and RILEM TC-107-GCS Model B3.................................................................... 46

Table A-1: Batch Record for N45-A........................................................................... 70

Table A-2: Batch Record for N45-B................................................................... 71

Table A-3: Batch Record for R45-25 ....................................................................... 72

Table A-4: Batch Record for R45-50 ................................................................. 73

Table A-5: Batch Record for R45-50 ...................................................................... 74

Table A-6: Batch Record for R45-100 ........................................................................... 75

Table A-7: Batch Record for RS45-50 ...................................................................... 76

Table A-8: Batch Record for RS45-100 ....................................................................... 77

Table A-9: Batch Record for RD45-50................................................................. 78

Table A-10: Batch Record for RD45-100........................................................... 79

Table A-11: Batch Record for RID45-100 ........................................................................ 80

Table A-12: Batch Record for RHD45-100 .................................................................... 81

Table A-13: Batch Record for N60 .................................................................... 82

Table A-14: Batch Record for R60-100 ............................................................................ 83

Table A-15: Batch Record for RS60-100 ................................................................. 84

Table A-16: Batch Record for RD60-100............................................................. 85

Table A-17: Batch Record for N30 .................................................................................. 86

Table A-18: Batch Record for R30-100 ................................................................. 87

Table A-19: Batch Record for RS30-100 ............................................................... 88

Table A-20: Batch Record for RD30-100............................................................. 89

Table B-1: Prismatic Beam Specimen Data (N45-B) ................................................. 91 
Table B-2: Prismatic Beam Specimen Data (R45-25).......................................... 92

Table B-3: Prismatic Beam Specimen Data (R45-50).......................................... 93

Table B-4: Prismatic Beam Specimen Data (R45-75)........................................... 94

Table B-5: Prismatic Beam Specimen Data (R45-100)........................................ 95

Table B-6: Prismatic Beam Specimen Data (RS45-50) .............................................. 96

Table B-7: Prismatic Beam Specimen Data (RS45-100) ....................................... 97

Table B-8: Prismatic Beam Specimen Data (RD45-50) .......................................... 98

Table B-9: Prismatic Beam Specimen Data (RD45-100) ......................................... 99

Table B-10: Prismatic Beam Specimen Data (RLD45-100) ...................................... 100

Table B-11: Prismatic Beam Specimen Data (RHD45-100)................................... 101

Table B-12: Prismatic Beam Specimen Data (N60) ............................................. 102

Table B-13: Prismatic Beam Specimen Data (R60-100)............................................ 103

Table B-14: Prismatic Beam Specimen Data (RS60-100) .......................................... 104

Table B-15: Prismatic Beam Specimen Data (RD60-100) .................................... 105

Table B-16: Prismatic Beam Specimen Data (N30) ................................................... 106

Table B-17: Prismatic Beam Specimen Data (R30-100)........................................ 107

Table B-18: Prismatic Beam Specimen Data (RS30-100) ......................................... 108

Table B-19: Prismatic Beam Specimen Data (RD30-100) ...................................... 109 


\section{List of Figures}

Figure 2-1: Breaking Apart Parent Concrete to Make RCA.....................................5

Figure 2-2: MC-64P Multiquip $0.17 \mathrm{~m}^{3}\left(6 \mathrm{ft}^{3}\right)$ Mixer ...................................................5

Figure 2-3: RCA types N, R, and RS (Pictured Left to Right) ...................................... 7

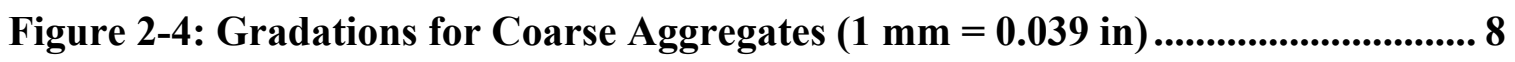

Figure 2-5: Prismatic Beam Form .................................................................... 11

Figure 2-6: Shrinkage Form (Plan and Profile View) and Gauge Stud..................... 12

Figure 2-7: MTS Test Frame \& Typ. Cylinder Compression Test Configuration... 13

Figure 2-8: Compressometer for Static Modulus of Elasticity Tests .......................... 13

Figure 2-9: Typical Stress-Strain Loading Curve for $E_{c}$ Specimen ........................... 14

Figure 2-10: Longitudinal Forced Resonance Method to Determine $E_{d}$.................... 15

Figure 2-11: Humboldt Length Change Measuring Apparatus (without \& with

Typical Shrinkage Specimen Testing Configuration) ..................................................... 16

Figure 2-12: Shelf Storage for Drying Shrinkage Specimens ...................................... 17

Figure 2-13: Interior (left) and Exterior (right) of Climatic Chamber...................... 17

Figure 2-14: Example of LabVIEW Data Monitoring Interface................................ 18

Figure 2-15: Temperature and Humidity History of Climatic Chamber................... 18

Figure 3-1: Improvement of Shrinkage Model using Least Squares Analysis for

ACI209R-92 (R45-100) ............................................................................................................... 25

Figure 4-1: Relationship Between 28-day Compressive Strength and w/c Ratio for Different Coarse Aggregates; (100\% Replacement, $1 \mathrm{MPa}=145.0$ psi) ............. 29

Figure 4-2: Relationship Between 28-day Compressive Strength and Increasing

RCA Replacement Percentage; $(\mathrm{w} / \mathrm{c}=0.45,1 \mathrm{MPa}=145.0 \mathrm{psi})$ 30

Figure 4-3: Relationship Between 28-day Static Modulus of Elasticity and w/c

Ratio for Different Coarse Aggregates; (100\% Replacement, 1 GPa = 145.0 ksi)... 32

Figure 4-4: Relationship Between 28-day Static Modulus of Elasticity and

Increasing RCA Replacement Percentage; $(w / c=0.45,1$ GPa $=145.0 \mathrm{ksi})$

Figure 4-5: Relationship Between 90-day Dynamic Modulus of Elasticity and w/c

Ratio for Different Coarse Aggregates; (100\% Replacement, 1 GPa = 145.0 ksi).... 35 
Figure 4-6: Relationship Between 90-day Dynamic Modulus of Elasticity and Increasing RCA Replacement Percentage; $(w / \mathrm{c}=0.45,1$ GPa $=145.0 \mathrm{ksi}) . . . . . . . . . . . .36$

Figure 4-7: Development of $E_{d}$ with Age (Control Concretes) ................................ 38

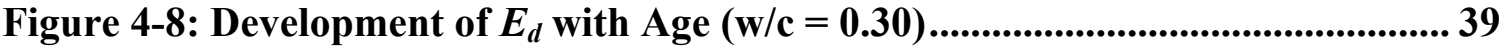

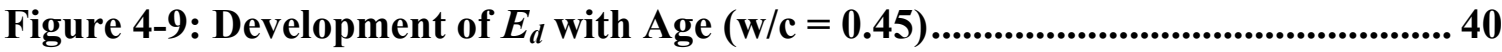

Figure 4-10: Development of $E_{d}$ with Age (w/c = 0.60) ....................................... 40

Figure 4-11: Development of $E_{d}$ with Age (100\% RCA type R) ................................. 41

Figure 4-12: Development of $E_{d}$ with Age (100\% RCA type RS)............................ 42

Figure 4-13: Development of $E_{d}$ with Age (100\% RCA type RD) ............................... 42

Figure 4-14: Development of $E_{d}$ with Age (0 - 100\% RCA type R) ........................ 43

Figure 4-15: Examining $E_{c} / E_{d}$ Ratio with Increasing Levels of RCA type R........... 44

Figure 4-16: Modulus of Elasticity as a Function of Compressive Strength for

Concrete Made w/ 100\% RCA; 1 MPa = 145.0 psi ................................................... 45

Figure 4-17: Drying Shrinkage Curves for Control Concretes ................................. 47

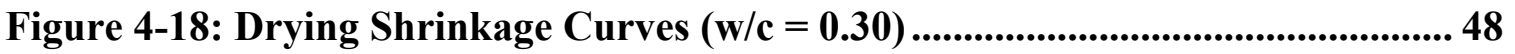

Figure 4-19: Drying Shrinkage Curves (w/c =0.45) .................................................... 48

Figure 4-20: Drying Shrinkage Curves $(w / c=0.60)$................................................... 49

Figure 4-21: Drying Shrinkage Curves (100\% RCA type R) .................................. 51

Figure 4-22: Drying Shrinkage Curves (100\% RCA type RS) ................................... 51

Figure 4-23: Drying Shrinkage Curves (100\% RCA type RD) ................................... 52

Figure 4-24: Drying Shrinkage Curves (25 - 100\% RCA type R) ........................... 53

Figure 4-25: Drying Shrinkage Curves (50 \& 100\% RCA types RS \& RD) ............ 53

Figure 4-26: Ultimate Shrinkage as a Function of Increasing RCA Replacement

Percentage (w/c = 0.45, per ACI 209R-92) .............................................................. 55

Figure 4-27: Ultimate Shrinkage as a Function of Increasing RCA Replacement

Percentage (w/c = 0.45, per RILEM TC-107-GCS Model B3)................................. 55

Figure 4-28: General Relationship between 28-day Compressive Strength and Ultimate Shrinkage (per ACI 209R-92); $1 \mathrm{MPa}=145.0$ psi 57

Figure 4-29: General Relationship between 28-day Static Modulus of Elasticity and Ultimate Shrinkage (per ACI 209R-92); 1 GPa $=145.0$ ksi 
Figure 4-30: General Relationship between 28-day Dynamic Modulus of Elasticity and Ultimate Shrinkage (per ACI 209R-92); 1 GPa $=145.0$ psi............... 58

Figure C-1: Shrinkage Specimen Data w/ Prediction Curves (N45-A).................... 111

Figure C-2: Shrinkage Specimen Data w/ Prediction Curves (N45-B).................... 111

Figure C-3: Shrinkage Specimen Data w/ Prediction Curves (R45-25).................... 112

Figure C-4: Shrinkage Specimen Data w/ Prediction Curves (R45-50)................... 112

Figure C-5: Shrinkage Specimen Data w/ Prediction Curves (R45-75).................... 113

Figure C-6: Shrinkage Specimen Data w/ Prediction Curves (R45-100)................. 113

Figure C-7: Shrinkage Specimen Data w/ Prediction Curves (RS45-50) ................. 114

Figure C-8: Shrinkage Specimen Data w/ Prediction Curves (RS45-100) .............. 114

Figure C-9: Shrinkage Specimen Data w/ Prediction Curves (RD45-50)................ 115

Figure C-10: Shrinkage Specimen Data w/ Prediction Curves (RD45-100)............ 115

Figure C-11: Shrinkage Specimen Data w/ Prediction Curves (RLD45-50) ........... 116

Figure C-12: Shrinkage Specimen Data w/ Prediction Curves (RHD45-100)......... 116

Figure C-13: Shrinkage Specimen Data w/ Prediction Curves (N60)....................... 117

Figure C-14: Shrinkage Specimen Data w/ Prediction Curves (R60-100)............... 117

Figure C-15: Shrinkage Specimen Data w/ Prediction Curves (RS60-100) ............. 118

Figure C-16: Shrinkage Specimen Data w/ Prediction Curves (RD60-100)............ 118

Figure C-17: Shrinkage Specimen Data w/ Prediction Curves (N30)...................... 119

Figure C-18: Shrinkage Specimen Data w/ Prediction Curves (R30-100)................ 119

Figure C-19: Shrinkage Specimen Data w/ Prediction Curves (RS30-100) ............ 120

Figure C-20: Shrinkage Specimen Data w/ Prediction Curves (RD30-100)............ 120 


\section{Chapter 1 Introduction}

\subsection{Background}

Investigation into the use of recycled concrete as a source for new aggregates in concrete has been the focus of numerous studies spanning multiple decades ${ }^{1,2}$. These studies indicate that construction and demolition waste (CDW) can be recycled by various methods of crushing ${ }^{3-6}$ and used to produce recycled aggregates which are suitable for use in new concrete ${ }^{6-9}$. CDW accounts for approximately $25-45 \%$ of all waste produced in North America ${ }^{10}$. Concrete is the most widely used building material in the construction industry, and with increasing construction and demolition projects, CDW is only likely to increase ${ }^{4,5,11}$. Currently recycled aggregates are used in lower quality projects ${ }^{4-6,12-14}$, and tend to be avoided for higher quality structural concrete applications ${ }^{4,6,15}$. However, some studies performed show that recycled concrete aggregates can in fact be utilized in high-strength concretes used for important structural applications ${ }^{16-19}$. Additional field studies have demonstrated that concrete containing recycled aggregates is workable and finishes well, with construction workers unable to notice any difference ${ }^{18}$. Increasing the use of recycled aggregates in new concrete will 
help eliminate demands on natural resources, reduce landfill disposal, and reduce energy costs associated with transport and construction ${ }^{4,8,10,13,15,18,19}$.

Recycled aggregates typically contain crushed and uncrushed natural aggregate with attached mortar and some pieces of hardened mortar ${ }^{3,5,6,9,19-22}$. Recycled aggregate concretes (RAC) are defined as concrete using recycled aggregates or recycled aggregates in combination with natural aggregates ${ }^{23}$, and can be either of fine or coarse sizes $^{23,24}$. Recycled aggregates are typically not used in new concretes past a certain percent replacement due to the negative influence on compressive strength, modulus of elasticity, shrinkage, and creep. This negative influence is generally attributed to the presence of old mortar which adheres to recycled aggregates ${ }^{4,5,18,21}$. Performance of recycled aggregates greatly depends on the quality and quantity of this adhered $\operatorname{mortar}^{5,8,9,23,24}$. Recycled aggregates from pre-cast or reinforced concrete structures made with high-strength concretes have been shown to perform better as a recycled aggregate for new concrete ${ }^{10,24,25}$. Quantity of adhered mortar depends on the original w/c ratio of the concrete and crushing technique used ${ }^{5,20,23}$.

\subsection{Research Significance}

Properties of concrete made with recycled aggregates have been the focus of many experimental studies. This present study aims to expand knowledge on properties of recycled coarse aggregates (RCA) by mixing twenty different batches of concrete with three different water-cement $(\mathrm{w} / \mathrm{c})$ ratios and to use different coarse aggregate replacement percentages of natural aggregate with recycled aggregate. Compression, static and dynamic modulus of elasticity, and shrinkage are reported for five different types of RCA and compared to natural aggregate concrete. Predictive models for 
elasticity ${ }^{26}$ and ultimate shrinkage $e^{27,28}$ are used in conjunction with methods of statistical analysis to further study and explain how RCA affects these two strain-related properties of concrete. 


\section{Chapter 2 Experimental Procedure}

\subsection{Concrete Materials}

All concrete mixes used combinations of portland Type II/V cement, natural coarse aggregates, recycled coarse aggregates (RCA), water, and W.R. Grace ADVA 100 Superplasticizer. Cement was assumed to have a bulk specific gravity (BSG) of 3.15. Maximum size of coarse and fine aggregates was 25 and $4.75 \mathrm{~mm}$ (1" and No. 4), respectively. Crushed granite and Sisqouc sand were provided from local sources. RCA originated from two sources. One type of RCA came from a commercial recycling facility (RCA type R). The parent concrete properties of these RCA were unknown. The second type of RCA was manufactured in the laboratory. These recycled coarse aggregates originated from parent concretes with different water-cement $(w / c)$ ratios. Parent concrete was cast in forms with sizes of 140 × $200 \times 2130 \mathrm{~mm}\left(5 \frac{1}{2} \mathrm{x} \times 8 \times 84\right.$ "). Cylinder molds measuring $100 \mathrm{~mm}$ (4") by $200 \mathrm{~mm}$ (8") were cast to evaluate the 7 and 28 day compressive strength $\left(f^{\prime} c\right)$ of the parent concretes. Concrete was then broken up with a hammer 5,6 , and 7 hours after casting for concretes made with $0.30,0.45$, and $0.60 \mathrm{w} / \mathrm{c}$ ratios, respectively. This allowed for concrete to be broken into smaller particles 
while still maintaining physical characteristics of RCA. As the concrete was broken apart, it was sieved over a $25 \mathrm{~mm}$ (1") screen and placed in sealed containers.

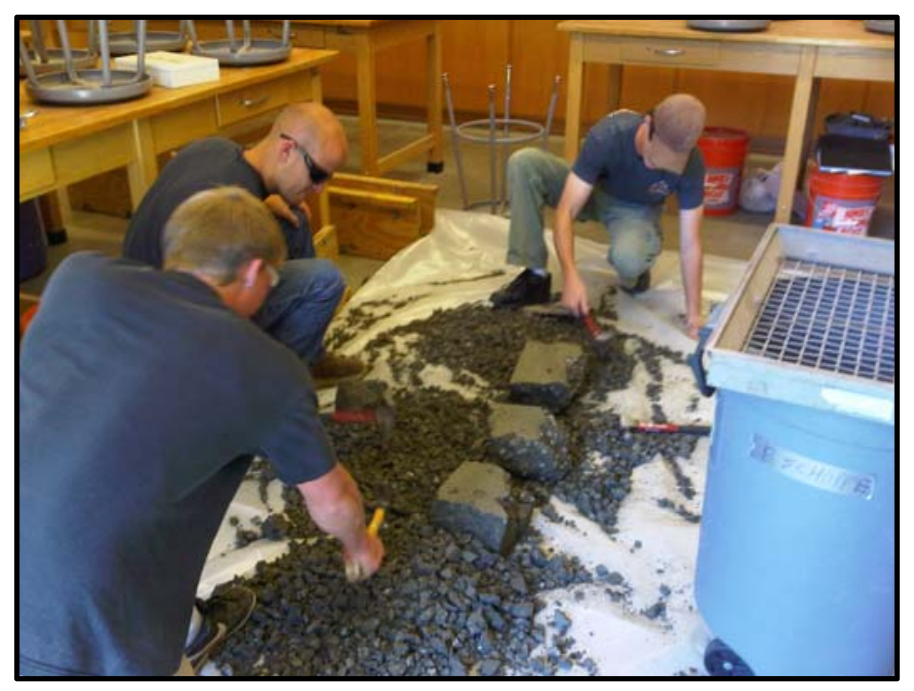

Figure 2-1: Breaking Apart Parent Concrete to Make RCA

These RCA were left to cure in the sealed containers for 7 days, after which the RCA were tumbled in a $0.17 \mathrm{~m}^{3}\left(6 \mathrm{ft}^{3}\right)$ empty concrete mixer for 25 rotations to remove any loose particles and create a smoother surface. These aggregates were then sieved over a $4.75 \mathrm{~mm}$ (No. 4) screen, and any passing material was discarded.

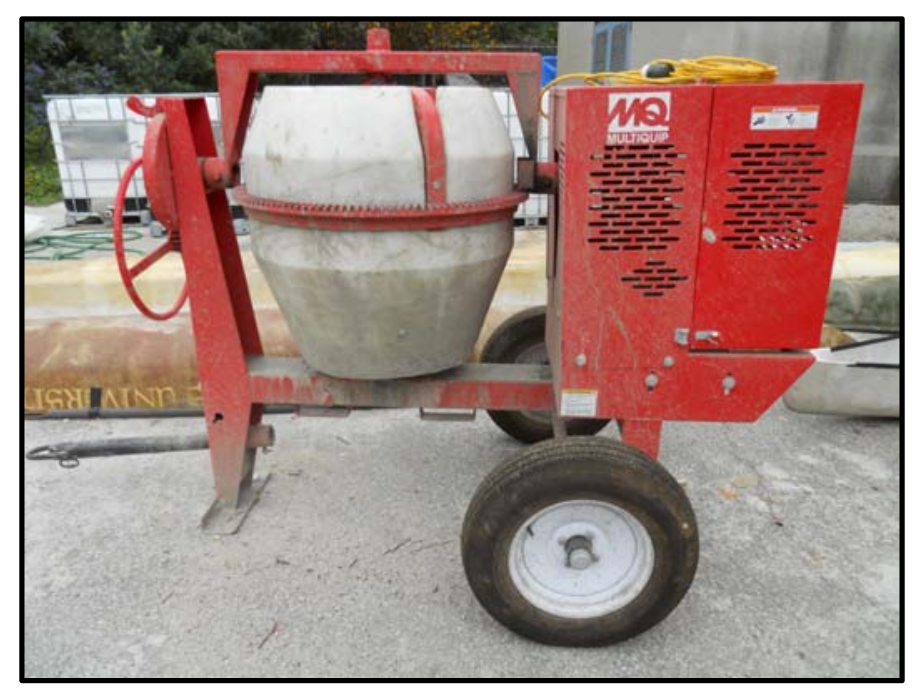

Figure 2-2: MC-64P Multiquip $0.17 \mathrm{~m}^{3}\left(6 \mathrm{ft}^{3}\right)$ Mixer 
RCA originating from 0.30 and $0.60 \mathrm{w} / \mathrm{c}$ parent concretes was left out to air dry, (RCA types RLD and RHD, respectively). RCA from the $0.45 \mathrm{w} / \mathrm{c}$ ratio concrete was divided into two categories: saturated (RCA type RS) and dried (RCA type RD). The saturated coarse aggregates were placed in a sealed lime bath container (100\% relative humidity). All recycled aggregates were left to saturate or dry for 30 days before being used in new concrete mixes. Table 2-1 presents a summary and description of all natural (type N) and recycled coarse aggregates used.

Table 2-1: Bulk Specific Gravity (BSG) and Absorption of Aggregates

\begin{tabular}{clccc}
\hline \hline Material ID & \multicolumn{1}{c}{ Description of Materials } & $\begin{array}{c}\text { Max. Size, } \\
\text { mm (in) }\end{array}$ & *BSG & $\begin{array}{c}\text { Absorption, } \\
\%\end{array}$ \\
\hline \hline Fine Agg. & Sisquoc C33 Sand - Fine Aggregate & 4.75 (No. 4) & 2.56 & 2.2 \\
\hline N & $\begin{array}{l}\text { Natural Coarse Aggregates - Santa Margarita } \\
\text { Crushed Granite }\end{array}$ & 2.61 & 1.4 \\
R & RCA - w/c unknown; from San Diego, CA & & 2.47 & 4.9 \\
RS & Saturated RCA - 0.45 w/c Parent Concrete & $25(1$ ”) & 2.44 & 5.4 \\
RD & Dried RCA - 0.45 w/c Parent Concrete & & 2.43 & 5.3 \\
RLD & Dried RCA - 0.30 w/c Parent Concrete & & 2.46 & 4.7 \\
RHD & Dried RCA - 0.60 w/c Parent Concrete & & 2.44 & 5.1 \\
\hline \hline
\end{tabular}

*Specific gravities were measured in the saturated surface-dried (SSD) condition.

Tests on the aggregates themselves were performed to various ASTM standards ${ }^{29-31}$ in order to determine physical properties of maximum size, bulk specific gravity, and water absorption. Table 2-1 presents these results along with a material identification (ID) for the aggregates. As evident from Table 2-1, RCAs have water absorption of approximately $5 \%$, whereas the natural coarse aggregates have water absorption of $1.4 \%$. These coarse aggregate absorption values are typical of natural and recycled coarse aggregate, as evidenced by previous studies ${ }^{1-6,9,12,13,20,22,24,32,33}$, and are the result of 
adhered mortar on the coarse aggregate, which causes increased porosity. Additionally, the BSG values for recycled coarse aggregates are smaller than that of natural coarse aggregates. This is also attributed to the presence of adhered mortar, causing increased porosity, and leads to lighter concretes ${ }^{1,4-6,9,12,15,20,24}$. Figure 2-3 depicts coarse aggregate types $\mathrm{N}, \mathrm{R}$, and RS.

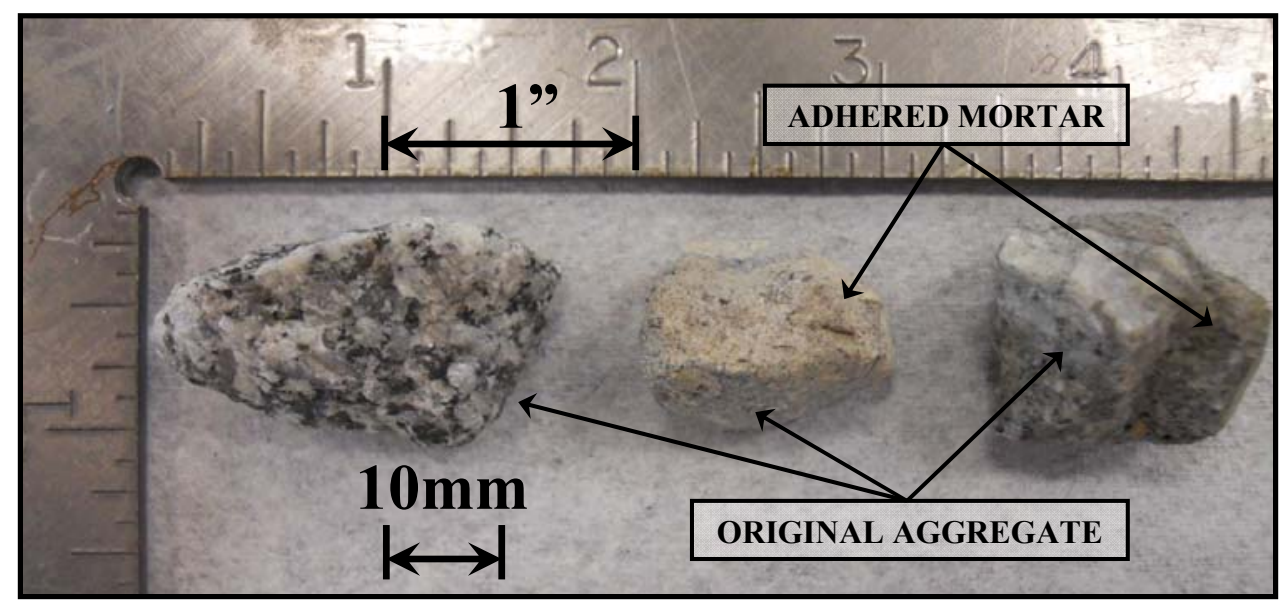

Figure 2-3: RCA types N, R, and RS (Pictured Left to Right)

RCA type RS is physically identical to RCA types RD, RLD, and RHD, and therefore only RS is pictured. Notable physical characteristics of these RCA include:

- Coarse natural aggregate with little or no mortar adhered to surface;

- Coarse natural aggregate with small to thick layers $(3-6 \mathrm{~mm})$ of mortar adhered to surface in one or more spots;

- Coarse natural aggregate with a lump of mortar on one side and;

- Particles made entirely of mortar.

Fine powder coated RCA type R, which was later discovered to substantially decrease workability. Aggregate type $\mathrm{N}$ can be identified by a sparkly crystalline appearance of granite, and is more angular than its recycled counterparts. These physical observations 
of the natural and recycled coarse aggregates are consistent with previous

literature $\mathrm{e}^{3,5,6,9,19-22}$. Figure 2-4 shows the gradations for the coarse aggregates. The upper limit is specified by ASTM C33 size 57, and the lower limit is specified by ASTM C33 size $56^{34}$. Although the grading limits are for different maximum-size coarse aggregates, grading for a particular maximum-size coarse aggregate can be varied over a moderate range without any noticeable effect on water and cement requirements for a concrete $\operatorname{mix}^{6}$

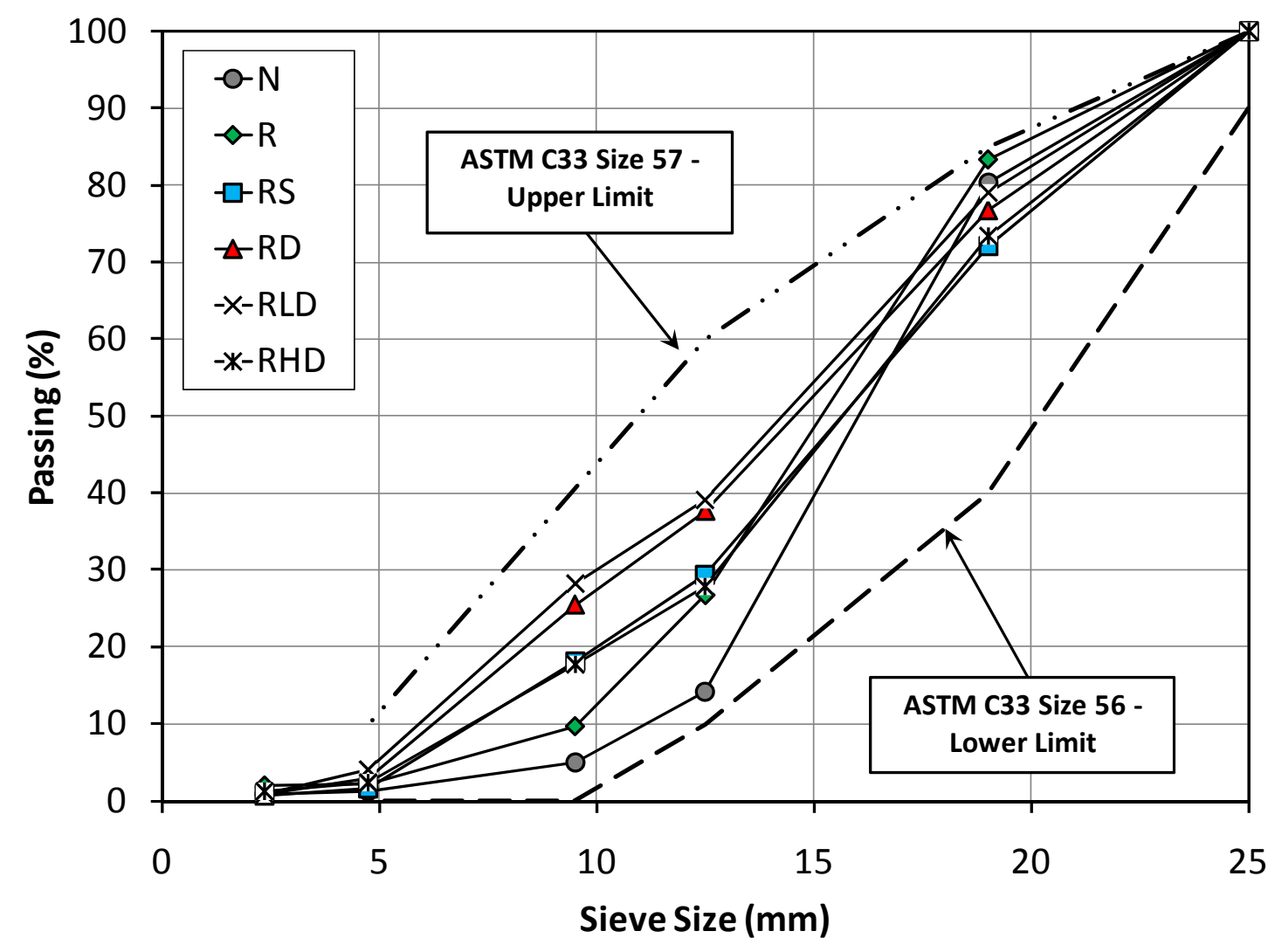

Figure 2-4: Gradations for Coarse Aggregates $(1 \mathrm{~mm}=\mathbf{0 . 0 3 9} \mathrm{in})$ 


\subsection{Mixture Proportions}

Twenty different concrete batches using natural and recycled coarse aggregate and natural fine aggregate are shown in Table 2-2. Natural fine aggregates were used in all batches due to the undesirable effects of fine recycled aggregates on hardened concrete $^{2,4,24,25,35}$.

Table 2-2: Details of Concrete Mixes

\begin{tabular}{|c|c|c|c|c|c|c|c|c|c|c|c|c|}
\hline \multirow{2}{*}{ Mix ID } & \multirow{2}{*}{$\begin{array}{l}\text { Batch } \\
\text { size, } \\
\mathrm{m}^{3}\end{array}$} & \multirow{2}{*}{$\begin{array}{c}\text { Cement, } \\
\mathrm{kg} / \mathrm{m}^{3}\end{array}$} & \multirow{2}{*}{$\begin{array}{l}\text { Water, } \\
\mathrm{kg} / \mathrm{m}^{3}\end{array}$} & \multirow{2}{*}{$\begin{array}{l}\text { Fine } \\
\text { Agg., } \\
\mathrm{kg} / \mathrm{m}^{3}\end{array}$} & \multirow[b]{2}{*}{$\mathrm{N}$} & \multicolumn{5}{|c|}{ Coarse Aggregates, $\mathrm{kg} / \mathrm{m}^{3}$} & \multirow{2}{*}{$\begin{array}{c}\text { Super- } \\
\text { plasticizer, } \\
\mathrm{L} / \mathrm{m}^{3}\end{array}$} & \multirow{2}{*}{$\mathrm{w} / \mathrm{c}$} \\
\hline & & & & & & $\mathrm{R}$ & $\mathrm{RS}$ & $\mathrm{RD}$ & RLD & RHD & & \\
\hline N45-A & 0.085 & 425 & 192 & 730 & 963 & - & - & - & - & - & 0.820 & 0.45 \\
\hline N45-B & 0.038 & 428 & 193 & 734 & 969 & - & - & - & - & - & 0.786 & 0.45 \\
\hline R45-25 & 0.038 & 429 & 193 & 736 & 729 & 230 & - & - & - & - & 0.946 & 0.45 \\
\hline R45-50 & 0.086 & 423 & 190 & 726 & 479 & 453 & - & - & - & - & 0.758 & 0.45 \\
\hline R45-75 & 0.035 & 427 & 192 & 733 & 242 & 687 & - & - & - & - & 1.215 & 0.45 \\
\hline R45-100 & 0.074 & 426 & 192 & 731 & - & 913 & - & - & - & - & 1.491 & 0.45 \\
\hline RS45-50 & 0.035 & 431 & 195 & 741 & 489 & - & 457 & - & - & - & 0.428 & 0.45 \\
\hline RS45-100 & 0.035 & 433 & 195 & 744 & - & - & 918 & - & - & - & 1.148 & 0.45 \\
\hline RD45-50 & 0.035 & 427 & 192 & 734 & 484 & - & - & 451 & - & - & 0.792 & 0.45 \\
\hline RD45-100 & 0.035 & 432 & 194 & 742 & - & - & - & 912 & - & - & 1.001 & 0.45 \\
\hline RLD45-100 & 0.035 & 430 & 193 & 737 & - & - & - & - & 917 & - & 0.853 & 0.45 \\
\hline RHD45-100 & 0.035 & 429 & 193 & 737 & - & - & - & - & - & 909 & 0.937 & 0.45 \\
\hline N60 & 0.075 & 316 & 194 & 803 & 953 & - & - & - & - & - & 0.335 & 0.61 \\
\hline R60-100 & 0.074 & 320 & 192 & 819 & - & 914 & - & - & - & - & 0.407 & 0.60 \\
\hline RS60-100 & 0.035 & 322 & 193 & 823 & - & - & 908 & - & - & - & 0.284 & 0.60 \\
\hline RD60-100 & 0.035 & 320 & 192 & 819 & - & - & - & 899 & - & - & 0.310 & 0.60 \\
\hline N30 & 0.035 & 645 & 194 & 563 & 973 & - & - & - & - & - & 2.332 & 0.30 \\
\hline R30-100 & 0.035 & 645 & 193 & 563 & - & 921 & - & - & - & - & 2.958 & 0.30 \\
\hline RS30-100 & 0.035 & 642 & 192 & 561 & - & - & 905 & - & - & - & 3.254 & 0.30 \\
\hline RD30-100 & 0.035 & 642 & 192 & 561 & - & - & - & 902 & - & - & 2.831 & 0.30 \\
\hline
\end{tabular}

Note: All mixture proportions given are the SSD weights. $1 \mathrm{~kg} / \mathrm{m}^{3}=0.593 \mathrm{lb} / \mathrm{yd}^{3}$ and $1 \mathrm{~L} / \mathrm{m}^{3}=.0387 \mathrm{oz} / \mathrm{yd}^{3}$. 
Concrete mixture IDs shown in Table 2-2 describe the coarse aggregate used, the $\mathrm{w} / \mathrm{c}$ ratio of the concrete mix, and the percent replacement of natural aggregate with RCA. For example, RS45-50 correlates to a concrete mix with 50 percent replacement of natural aggregate with RCA type RS and a w/c ratio of 0.45 . For multiple control concretes as seen with $0.45 \mathrm{w} / \mathrm{c}$ concretes, the mix ID is followed by the letters A or B.

Concrete batches were designed to have constant water content with w/c ratios of $0.30,0.45$, and 0.60 . For these w/c ratios, design strengths were approximately 60,45 , and $30 \mathrm{MPa}(8.4,6.4$, and $4.4 \mathrm{ksi})$, respectively, with slumps of $150-200 \mathrm{~mm}(6-8$ "). Superplasticizer was added while mixing to achieve the desired workability, and all mix designs used the saturated surface dry (SSD) condition of the aggregates. Addition of superplasticizers is a common technique employed when using recycled aggregates in concrete $^{3,10,23,25,36}$. Workability of RAC is directly influenced by the absorption, shape, texture, and level of replacement of recycled aggregate ${ }^{5,9,13,23}$. Reports ${ }^{6,37,38}$ confirm that the addition of superplasticizers causes negligible effects on compressive strength and modulus of elasticity, and negligible to minute $(10-20 \%)$ increases in shrinkage. Mixes with w/c of 0.45 used replacement levels of $0,25,50,75$, and $100 \%$, and mixes using w/c ratio of 0.30 and 0.60 had replacement levels of 0 and $100 \%$. Dried RCA were oven dried at $105{ }^{\circ} \mathrm{C}\left(220^{\circ} \mathrm{F}\right)$ for six hours and left to cool to room temperature prior to placement in a concrete mix. Moisture contents of the aggregates were also measured and accounted for when batching the concretes. Additional information for measured unit weight, air content, slump, and temperature of the concrete batches are in Appendix A - Batch Records. 


\subsection{Concrete Specimens}

Concrete specimens were prepared in general accordance with ASTM C192-0 $07^{39}$. Natural and/or recycled coarse aggregates, fine aggregates, and one-half of the total water were added to a model type MC-64P Multiquip $0.17 \mathrm{~m} 3\left(6 \mathrm{ft}^{3}\right)$ capacity mixer (see Figure 2-1) and dry mixed for 3 minutes. The mixer was then covered and the aggregates were left to sit for 3 minutes. Cement and the remaining water were then mixed in for another 3 minutes. Superplasticizer was added during this mixing phase until the desired slump was achieved. As shown in Table 2-2, the amount of superplasticizer increased with increasing levels of recycled aggregate and decreasing $\mathrm{w} / \mathrm{c}$ ratio. This is due to decreased workability commonly associated with $\mathrm{RAC}^{3,5,9,10,13,23,25,36}$. Unit weights and air contents (gravimetric) were determined per ASTM C138-10 $0^{40}$ using a $0.0141 \mathrm{~m}^{3}\left(0.498 \mathrm{ft}^{3}\right)$ calibrated container; mixture proportions in Table 2-2 are adjusted for these measured unit weights and air contents. Eight $100 \mathrm{~mm}$ (4") by $200 \mathrm{~mm}$ (8") cylinder molds, two $75 \times 95 \times 400 \mathrm{~mm}$ ( $3 \times 3.75 \times 16$ ") prismatic beam molds (see Figure 2-5), and four 75 x $75 \times 285 \mathrm{~mm}$ ( 3 × 3 x 11.25") shrinkage molds were prepared with an even coat of form oil or an equivalent substitute prior to mixing each batch.

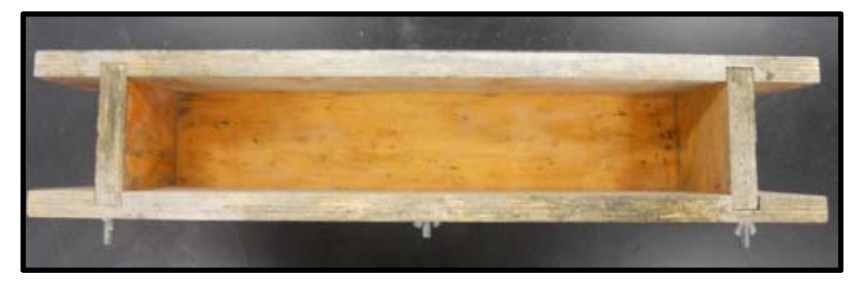

Figure 2-5: Prismatic Beam Form

Cylinder specimens were prepared in order to test 7 and 28 day compressive strengths $\left(f_{c}^{\prime}\right)$ and static modulus of elasticity $\left(E_{c}\right)$. Prismatic beam specimens were created to measure dynamic modulus of elasticity $\left(E_{d}\right)$. Shrinkage forms made from Plexiglas 
allowed gauge studs to be placed and adjusted in the center of the $75 \times 75 \mathrm{~mm}(3 \times 3$ ”) end plates such that they measured $254 \mathrm{~mm}(10$ ") end to end. These forms are shown in Figure 2-6 below.
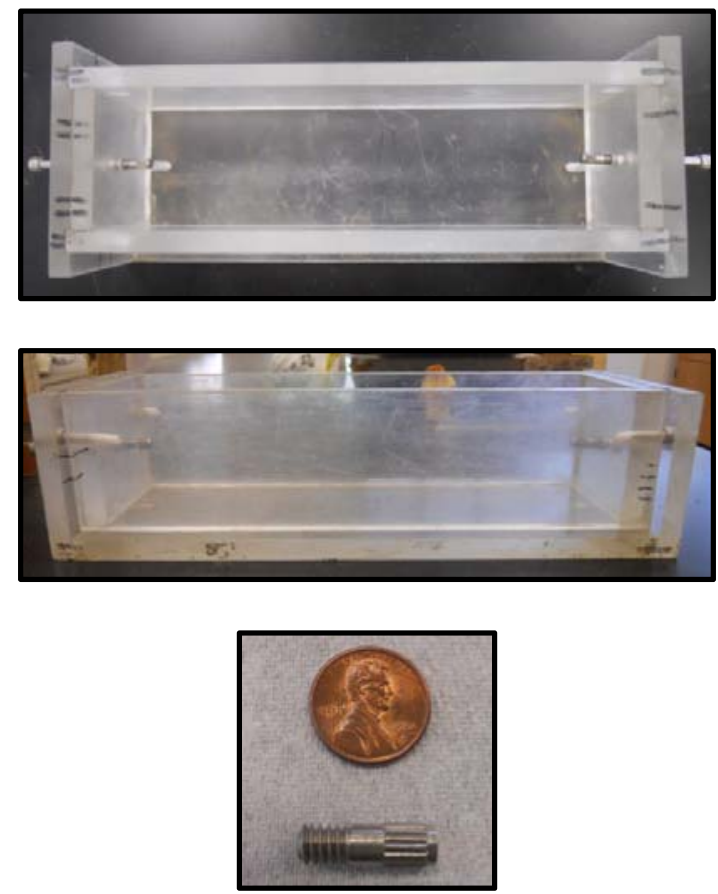

Figure 2-6: Shrinkage Form (Plan and Profile View) and Gauge Stud

All specimens were cured in molds at constant temperature and humidity of $23 \pm$ $2{ }^{\circ} \mathrm{C}\left(73 \pm 3{ }^{\circ} \mathrm{F}\right)$ and $70 \pm 5 \%$, respectively, for $24 \mathrm{hrs}$. Shrinkage and prismatic beam specimens were stored in the climatic chamber (details of which are discussed later), and cylinder specimens were placed in a moist room until testing.

Cylinder compression tests were conducted according to ASTM C $39-10^{41}$. The purpose of these compression tests was to observe changes in $f^{\prime}{ }_{c}$ between batches. Twenty-four hours prior to all compression tests, cylinders were capped using a sulfur compound which provided a smooth surface for the platen to contact and reduced variability between compression specimens. Four concrete cylinders from each batch 
were tested for $f_{c}^{\prime}$, (two at 7 days, and two at 28 days) and were performed on an MTS $500 \mathrm{kN}$ (112 kip) capacity testing frame (see Figure 2-7). Computer software controlled the load rate and collected data for the applied force every 0.5 seconds.
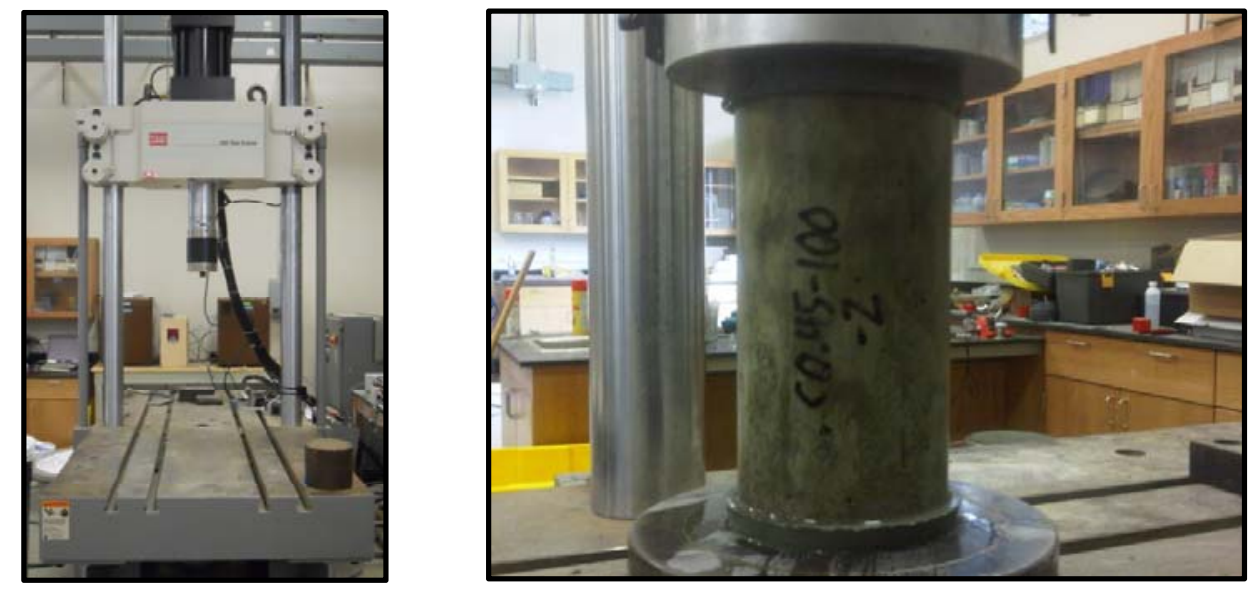

Figure 2-7: MTS Test Frame \& Typ. Cylinder Compression Test Configuration

The remaining four cylinders were tested for static (or chord) modulus of elasticity at 7 and 28 days following ASTM C469-10 ${ }^{42}$. A $2.54 \mathrm{~mm}(0.1$ ") linear variable differential transformer (LVDT) attached to a compressometer and wired to the aforementioned computer software was used in lieu of the standard strain gauge dial.

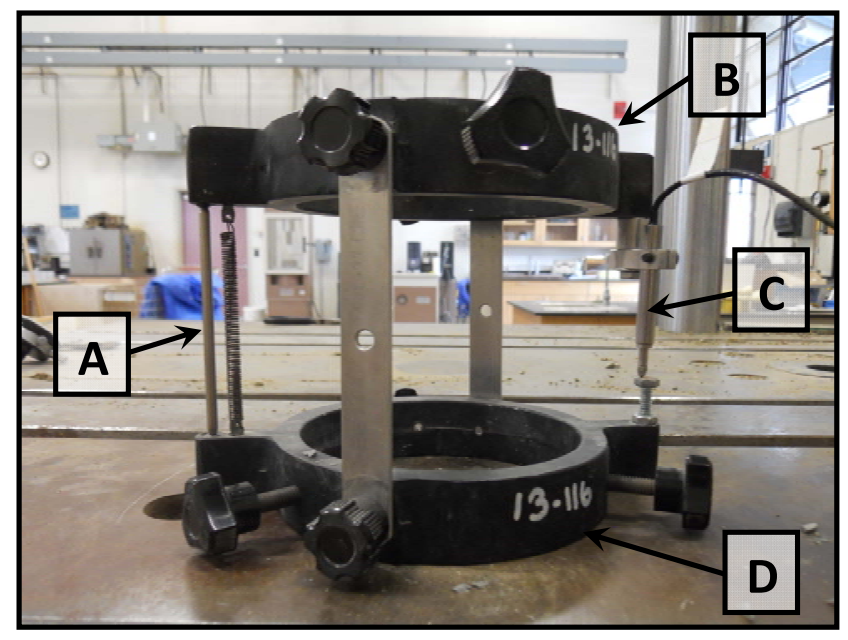

Figure 2-8: Compressometer for Static Modulus of Elasticity Tests 
This compressometer is shown in Figure 2-8, where: $\mathrm{A}=$ pivot rod, $\mathrm{B}=$ top yoke (free to rotate; two contact points), $\mathrm{C}=\mathrm{LVDT}$, and $\mathrm{D}=$ bottom yoke (rigidly attached; three contact points). Concrete cylinders for $E_{c}$ testing were also fitted with sulfur caps 24 hours prior to testing. Using data acquired from the $f_{c}^{\prime}$ of the same batch, loading cycled between $40 \%$ of $f^{\prime}{ }_{c}$ and $450 \mathrm{~N}$ (100 lbf) four times. Data for load and displacement was acquired automatically by the computer software, and the static modulus of elasticity of each specimen was calculated as the average of the three stress-strain chords using the following equation from ASTM C469-10 ${ }^{42}$ :

$$
E_{c}=\frac{S_{2}-S_{1}}{\varepsilon_{2}-0.000050}
$$

where $S_{2}$ is the stress corresponding to $40 \%$ of the ultimate load, $S_{1}$ is the stress corresponding to a longitudinal strain, $\varepsilon_{1}=50 \times 10^{-6}$, and the longitudinal strain produced by stress $S_{2}$. A typical stress-strain loading curve is shown in Figure 2-9.

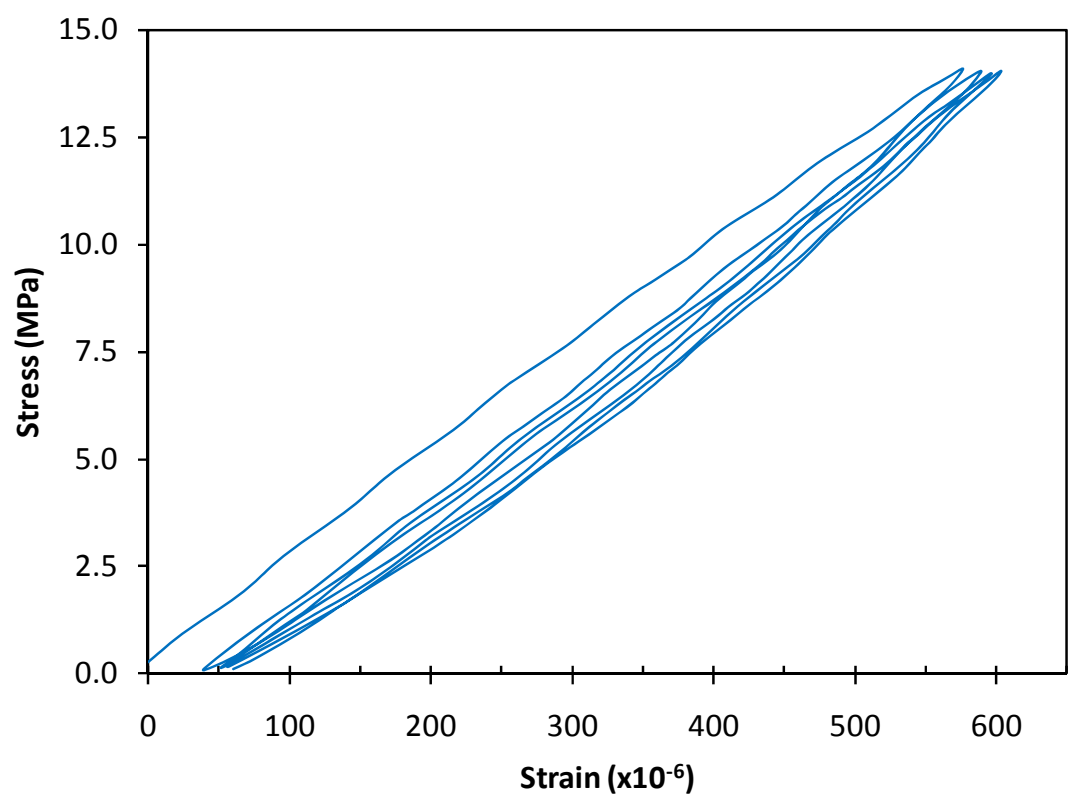

Figure 2-9: Typical Stress-Strain Loading Curve for $E_{c}$ Specimen 
Prismatic beam specimens were immediately placed in a lime water bath in the climatic chamber for 30 minutes after de-molding. They were then removed from the water bath to measure the mass and geometric properties, which were necessary to calculate $E_{d}$. Testing of the prismatic beams was conducted in accordance with ASTM C215- $08^{43}$. Following this standard, the prismatic beams were tested for their resonant frequency using the longitudinal mode configuration shown in Figure 2-10. From Figure 2-10, $\mathrm{A}=$ driver, $\mathrm{B}=$ prismatic beam specimen, $\mathrm{C}=$ accelerometer, and $\mathrm{D}=$ frequency indicator. Frequency readings were taken at 1, 3, 7, 14, 28, 60, and 90 days to monitor development of $E_{d}$ with age. $E_{d}$ was calculated from ASTM C215-08 ${ }^{43}$ using the following equation:

$$
E_{d}=d M\left(n^{\prime}\right)^{2}
$$

where $\mathrm{d}$ is a constant based on geometry of the specimen, $\mathrm{M}$ is the mass of the specimen, and n' is the longitudinal forced frequency in Hz. Specimens were returned to their lime water bath in the climatic chamber upon completion of the resonant frequency reading.

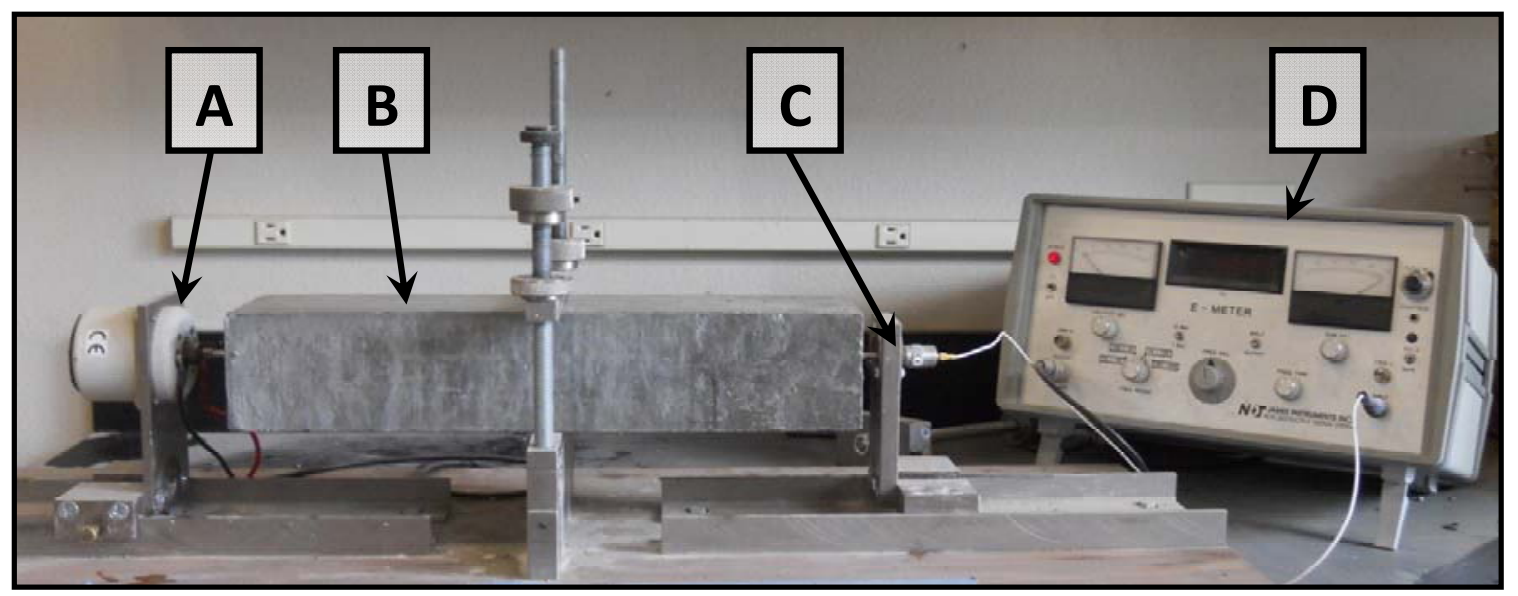

Figure 2-10: Longitudinal Forced Resonance Method to Determine $\boldsymbol{E}_{\boldsymbol{d}}$ 
Following ASTM C157- $08^{44}$, shrinkage specimens were also immediately placed in a lime water bath in the climatic chamber upon de-molding. Approximately 30 minutes after immersion in the lime water bath, the specimens were removed and an initial comparator reading was taken following ASTM C490-10 ${ }^{45}$ specifications using a Humboldt brand measuring apparatus shown in Figure 2-11. All shrinkage specimens remained in a lime water bath for 14 days, with readings taken at 1, 3, 7, and 14 days. After $14 \pm 1 / 2$ days, two of the shrinkage specimens were removed from the lime bath and left to undergo drying shrinkage in the climatic chamber. From this point, readings of the drying shrinkage specimens were taken at 1, 3, 7, 14, 28, 60, and 90 days (at the minimum) to investigate shrinkage progression.
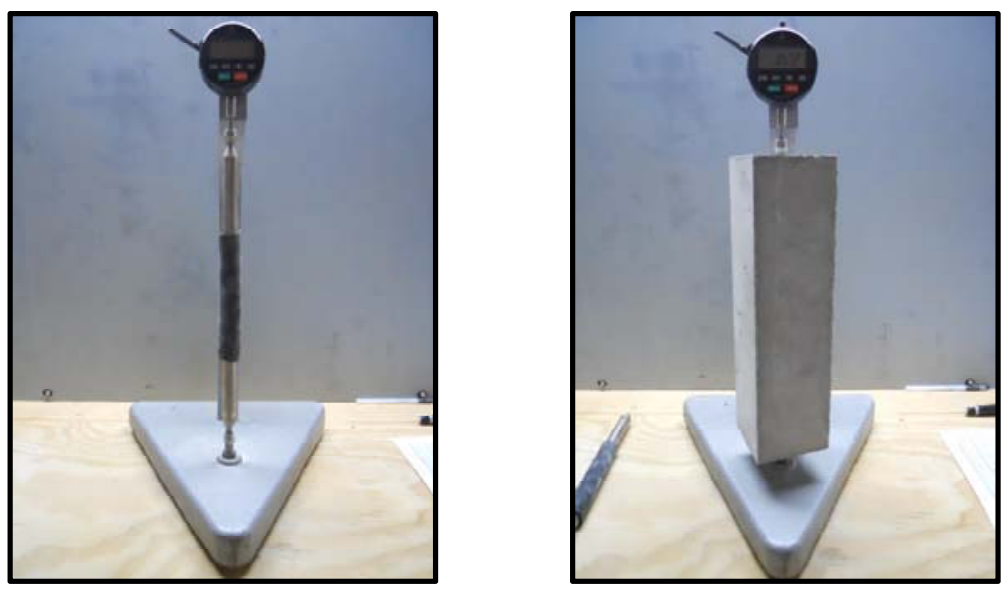

Figure 2-11: Humboldt Length Change Measuring Apparatus (without \& with Typical Shrinkage Specimen Testing Configuration)

\subsection{Climatic Chamber}

In order to control the temperature and humidity for specific concrete specimen storage, a temperature and humidity control room, or climatic chamber, was constructed. The dimensions of the interior of the climatic chamber are $1.52 \times 2.03 \times 2.13 \mathrm{~m}(60 \times 80$ x 84"). Details of the climatic chamber include shelf storage for concrete shrinkage 
specimens (see Figure 2-12), large plastic containers containing lime water conforming to ASTM C511- $09^{46}$, a counter to hold the apparatus used for shrinkage measurements, and an air conditioner, heater, humidifier, dehumidifier, fan, and climate sensor (see Figure 213).

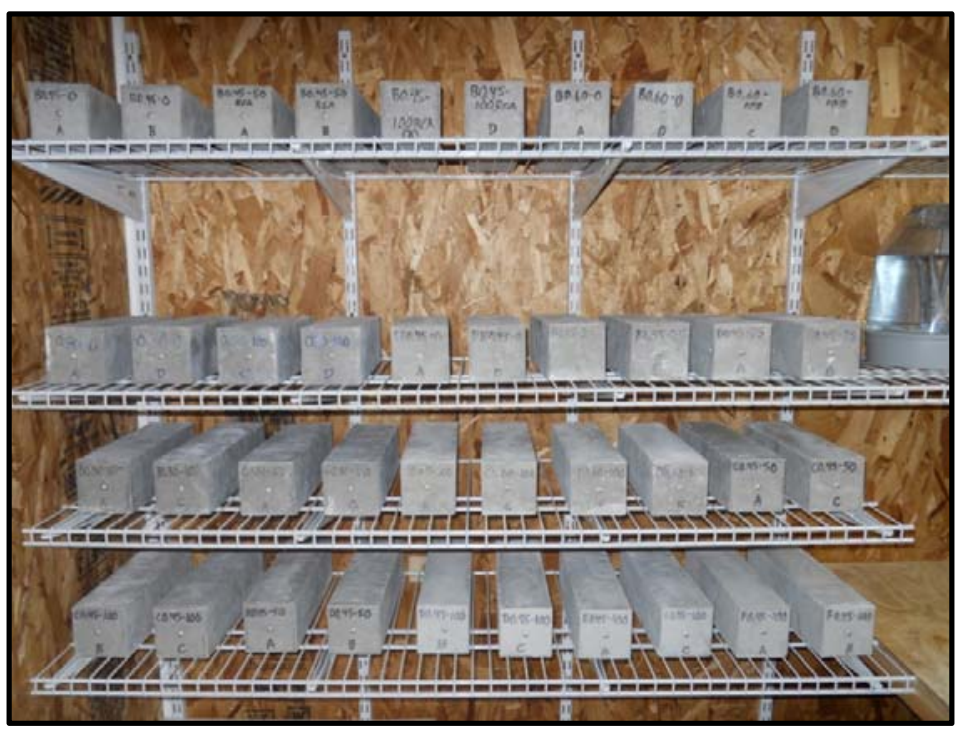

Figure 2-12: Shelf Storage for Drying Shrinkage Specimens

The items noted in Figure 2-13 are: $\mathrm{A}=$ humidifier, $\mathrm{B}=$ heater, $\mathrm{C}=$ dehumidifier, $\mathrm{D}=$ Humboldt length change measuring apparatus, $\mathrm{E}=$ air conditioner and $\mathrm{F}=$ temperature and humidity control software.
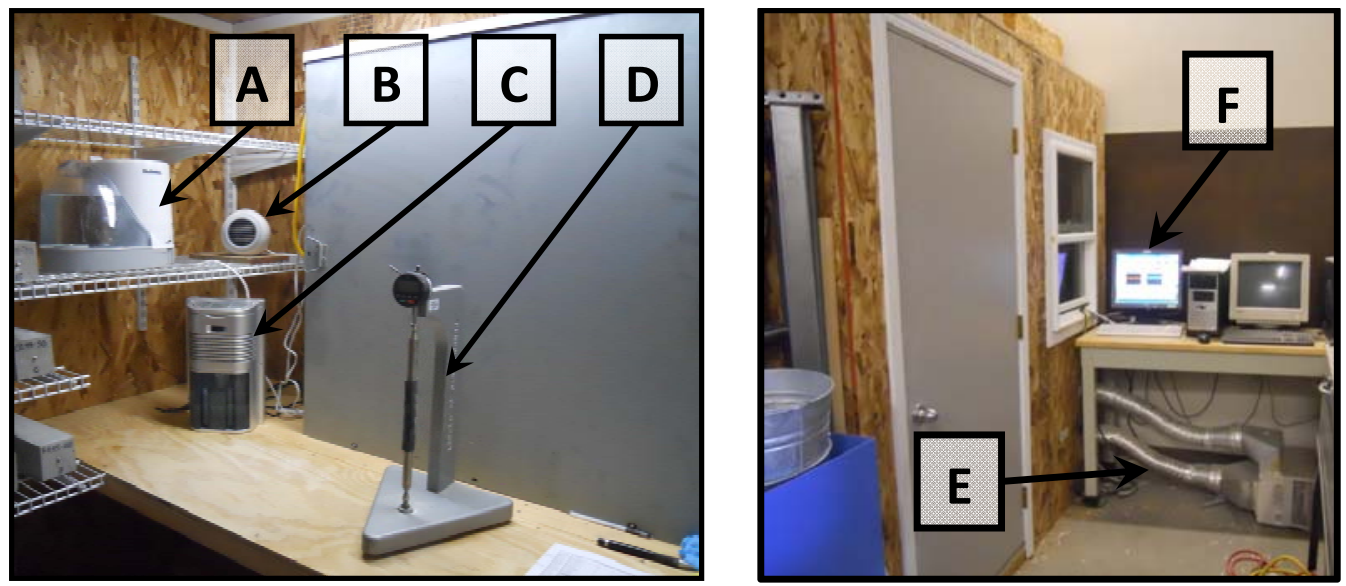

Figure 2-13: Interior (left) and Exterior (right) of Climatic Chamber 
Computer software on an external computer controlled the air conditioner, heater, humidifier, and dehumidifier such that the room maintained a temperature and humidity of $23 \pm 2{ }^{\circ} \mathrm{C}\left(74 \pm 3{ }^{\circ} \mathrm{F}\right)$ and $50 \pm 4 \%$, respectively, as required by ASTM C157-0 $88^{44}$. Figures 2-14 and 2-15 below show an example of the LabVIEW interface and the temperature and humidity in the climatic chamber for the testing duration, respectively.

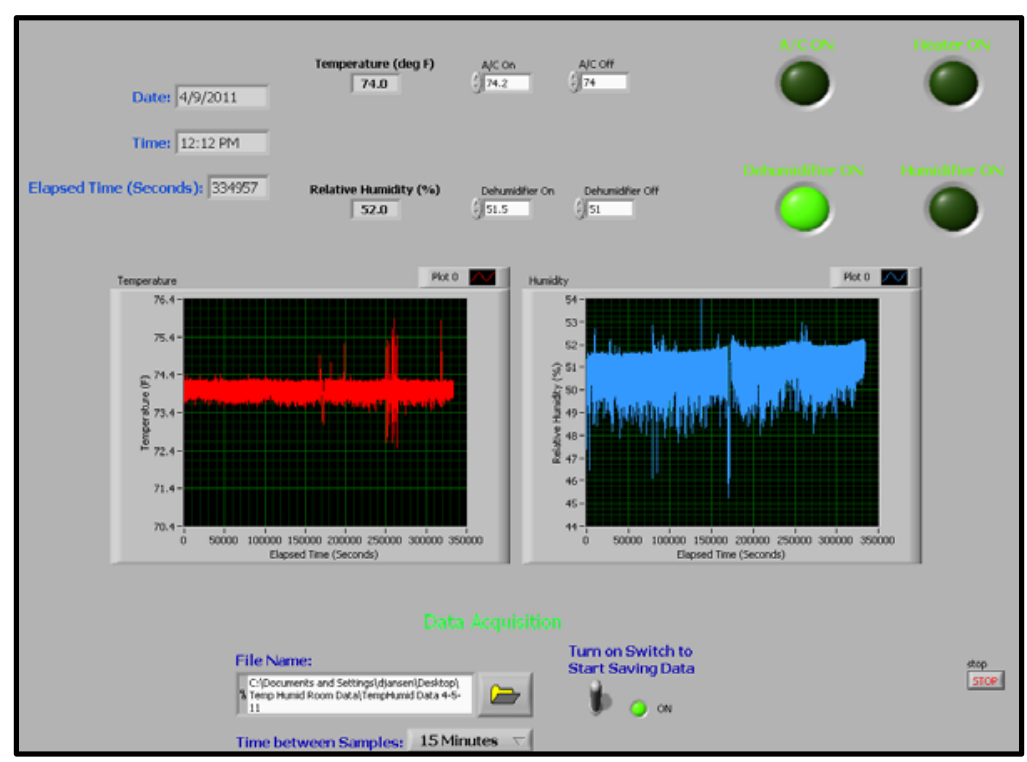

Figure 2-14: Example of LabVIEW Data Monitoring Interface

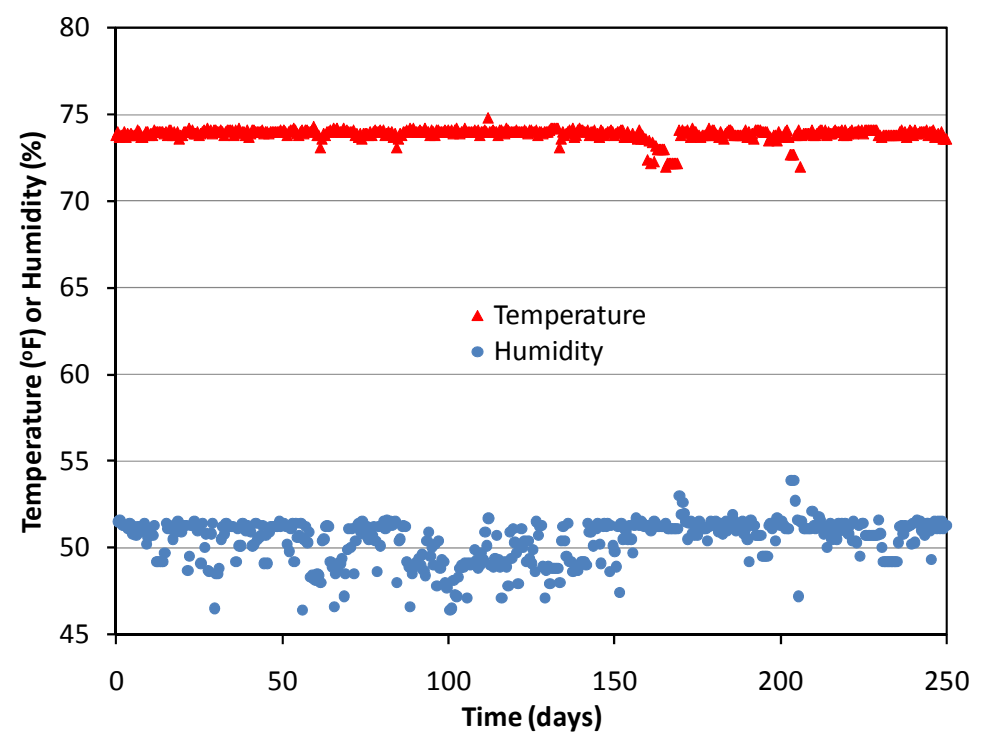

Figure 2-15: Temperature and Humidity History of Climatic Chamber 


\section{Chapter 3 Analytical Investigation}

\subsection{Elasticity Models}

Previous research has discovered that elasticity and shrinkage in concrete, especially RAC, is highly dependent on the properties of the constituent materials in the concrete, namely the modulus of elasticity and volumetric proportions of aggregates and mortar $6,7,26-28,47$. The quality of the aggregates ultimately determines a concrete specimen's potential for strength, modulus of elasticity and resistance to shrinkage $e^{6,7,26,27,47}$. Strength and modulus of elasticity values tend to be smaller for RAC than for natural aggregate concrete. This is attributed to a lower modulus of elasticity of the recycled concrete aggregates themselves ${ }^{14,23}$ and a weaker interface between old mortar and new mortar ${ }^{18,23,33,48}$. To better describe the modulus of elasticity of concrete as a function of its constituent materials, it is beneficial to model the concrete itself as a composite material. Mindess et al. ${ }^{26}$ states that composite models are used to determine the importance of certain materials on the overall behavior of the concrete, and as such the concrete is modeled as a two- or three-phase material. Aggregate and paste phases for these types of models are considered to be homogeneous and isotropic. 
Furthermore, these models can provide reasonable approximations of the mechanical behavior of concrete when the properties of the constituent materials are known ${ }^{26}$. In this study, the properties of the constituent materials are unknown but can be approximated using a common statistical analysis technique known as least square regression. Least squares regression analysis is commonly used to predict the dependant variable (in this case the modulus of elasticity of the concrete) when the independent variables (the modulus of elasticity of the coarse aggregates and the mortar) are unknown. In particular, nonlinear least squares regression models can be used to fit almost any function which can be written in a closed form ${ }^{49}$. For a three-phase composite material, such as the case in this study, it is beneficial to use the Logarithmic Mixture Rule for modeling elasticity of concrete. From Mindess et al. ${ }^{26}$, this equation is as follows:

$$
E_{c}=E_{p}^{V_{p}} E_{a}^{V_{a}}
$$

where $E_{c}=$ modulus of elasticity for the concrete, $E_{p}=$ modulus of elasticity for cement paste, $E_{a}=$ modulus of elasticity of the aggregate, $V_{p}=$ volume fraction of the cement paste, and $V_{a}=$ volume fraction of the aggregates. All values of modulus of elasticity are in $\mathrm{GPa}(\mathrm{ksi})$. This equation is modified by substituting mortar for cement paste and coarse aggregates for aggregates, where mortar describes the combination of cement, water, air, and fine aggregate. For the given set of variables for elasticity of coarse aggregates and volume fractions of mortar, this equation is expanded to:

$$
E_{c}=E_{m 0.30}{ }^{V_{m 0.30}} E_{m 0.45}{ }^{V_{m 0.45}} E_{m 0.60}{ }^{V_{m 0.60}} E_{N}{ }^{V_{N}} E_{R}{ }^{V_{R}} E_{R S}^{V_{R S}} E_{R D}{ }^{V_{R D}} E_{R L D}{ }^{V_{R L D}} E_{R H D}{ }^{V_{R H D}}
$$

The elasticity and volume fraction of cement paste, $E_{p}$ and $V_{p}$, respectively, have been replaced with the elasticity and volume fractions of the mortar for the different w/c ratios. Additionally, the elasticity and volume fraction of the aggregates, $E_{a}$ and $V_{a}$, respectively, 
have been replaced with the elasticity and volume fractions of coarse aggregate types $\mathrm{N}$, $\mathrm{R}, \mathrm{RS}, \mathrm{RD}, \mathrm{RLD}$, and RHD. Least squares regression was used to predict $E_{c}$ by changing modulus of elasticity values for the mortar at different w/c ratios and modulus of elasticity values for aggregate types N, R, RS, RD, RLD, and RHD. Despite lack of sensitivity in the data due to volume fractions of mortar and aggregates being relatively constant across concrete mixes ( 0.63 and 0.37 , respectively), the relative trends in modulus of elasticity values for mortar and aggregates can still be observed. The actual values for the elasticity of the aggregates and mortar can be approximated by selecting a value for the natural aggregate known from previous research. To prove the validity of the elasticity model, known values for the elasticity of natural coarse aggregate were used from previous literature ${ }^{50,51}$. These sources indicate that elasticity of granite is approximately $7-8 \times 10^{6}$ psi. This elasticity value was held as a constant in the model, thus creating a base for which the remaining elasticity values could be calculated. For example, if elasticity of the natural aggregate is fixed at $7.5 \times 10^{6}$ psi, the resulting modulus of elasticity for the mortar are $3.4 \times 10^{6}, 2.8 \times 10^{6}$, and $2.2 \times 10^{6} \mathrm{psi}$ for w/c ratios $0.30,0.45$, and 0.60 , respectively. Mindess et $\mathrm{al}^{26}$ reports elasticity of the cement paste alone to be in the range of $1-4 \times 10^{6} \mathrm{psi}$. Assuming the elasticity of the mortar is approximately equal to the cement paste, the calculated values are within the range of acceptable values. Normalized values for elasticity of the mortar and coarse aggregates were obtained by running multiple simulations of the elasticity model following the above example. Regardless of the starting value of the natural coarse aggregate, the normalized values were almost always identical. To observe the relative difference in values between the different aggregates and mortar phases of the concrete, predictions for 
modulus of elasticity of the aggregates were normalized to the modulus of elasticity of the coarse natural aggregate, and predictions for modulus of elasticity of the mortar were normalized to the modulus of elasticity of the $0.45 \mathrm{w} / \mathrm{c}$ mortar.

Modulus of elasticity is often predicted as a function of $f_{c}^{\prime}$ of the concrete. For normal weight concretes, ACI $318-08^{50}$ allows $E_{c}$ to be calculated as:

$$
E_{c}=4.73 \sqrt{f_{c}^{\prime}}
$$

where $E_{c}$ is the static modulus of elasticity of the concrete in GPa, and $f^{\prime}{ }_{c}$ is the cylinder compressive strength of the concrete in $\mathrm{MPa}(1 \mathrm{MPa}$ is $145.0 \mathrm{psi})$. In a study performed by Ravindrarajah and $\mathrm{Tam}^{22}$, static and dynamic modulus of elasticity for RCA concretes is modeled as a function of $f_{c}^{\prime}$ based on ACI 318's format:

$$
\begin{aligned}
& E_{c}=4.63 \sqrt{f^{\prime}{ }_{c}} \\
& E_{d}=6.19 \sqrt{f^{\prime}{ }_{c}}
\end{aligned}
$$

where $E_{c}$ and $E_{d}$ are the static and dynamic modulus of elasticity of the recycled concrete in GPa, respectively, and $f_{c}^{\prime}$ is the cylinder compressive strength of the recycled concrete in MPa. Following the general model of these equations and using least squares analysis, the coefficient of these equations was changed to best predict $E_{c}$ and $E_{d}$ values found from testing batches using 100\% RCA. Both elasticity models are discussed and related to experimental data in later sections.

\subsection{Ultimate Shrinkage Prediction Models}

Studies examining the use of recycled aggregate in concrete commonly discuss its effects on shrinkage. General consensus of these studies is that strain due to shrinkage, or microstrain, increases when natural aggregates are replaced with recycled aggregates 
in new concrete ${ }^{1,2,7,8,19,22,9,24,25,53-55}$. Shrinkage prediction models have been shown to adequately predict shrinkage in concrete ${ }^{56,57}$. In order to further examine the effects RCA have on shrinkage in this study, one shrinkage prediction equation was used from ACI 209R-92 $2^{57}$

$$
S_{t}=\frac{t}{t_{0}+t} S_{u l t}
$$

where $S_{t}=$ shrinkage after $t$ days since the end of moist curing, $S_{u l t}=$ ultimate shrinkage, $t=$ time in days since end of moist curing, and $\mathrm{t}_{0}=$ shrinkage half-time, which is the time in days for half the ultimate shrinkage expected to occur. Per ACI 209R-92, $t_{0}$ is equal to 35 days. After shrinkage data had been acquired for 150 days, least squares regression was used to predict values for $S_{t}$ corresponding to the acquired set of data for time $t$, while changing the value of $S_{u l t}$ and $t_{0}$ to best fit this acquired data. Since two shrinkage specimens were monitored for each batch of concrete, predicted values of $S_{t}$ were compared to the resulting average of strain values for any particular time $t$. As an example, Table 3-1 shows data predicted using $t_{0}$ equal to 35 days and $S_{u l t}$ equal to the average strain of the two specimens at 150 days. Using least squares analysis on this set of data, values for $t_{0}$ and $S_{u l t}$ are changed to best model the data; both resulting shrinkage curves are shown in comparison to the acquired data in Figure 3-1. 
Table 3-1: Example of Least Squares Analysis for ACI209R-92 (R45-100)

\begin{tabular}{|c|c|c|c|c|c|c|c|}
\hline \multirow{3}{*}{$t$, days } & \multirow{2}{*}{\multicolumn{3}{|c|}{ Strain due to Shrinkage $\left(\times 10^{-6}\right)$}} & \multicolumn{2}{|c|}{ Least Squares Analysis on $\mathrm{S}_{\mathrm{ult}}$} & \multicolumn{2}{|c|}{ Least Squares Analysis on $\mathrm{S}_{\mathrm{ult}}$ and $\mathrm{t}_{0}$} \\
\hline & & & & & & & \\
\hline & Specimen 1 & Specimen 2 & Ave & $S_{t}\left(\mathrm{x} 10^{-6}\right)$ & $\left(\text { Ave- } S_{t}\right)^{2}$ & $S_{t}\left(\mathrm{x} 10^{-6}\right)$ & $\left(\text { Ave- } S_{t}\right)^{2}$ \\
\hline 0 & 0 & 0 & 0 & 0 & 0 & 0 & 0 \\
\hline 1 & -40 & -60 & -50 & -26 & 578 & -34 & 266 \\
\hline 3 & -100 & -120 & -110 & -71 & 1490 & -91 & 373 \\
\hline 7 & -170 & -190 & -180 & -155 & 625 & -190 & 91 \\
\hline 14 & -290 & -300 & -295 & -265 & 880 & -309 & 201 \\
\hline 21 & -410 & -390 & -400 & -355 & 2026 & -398 & 3 \\
\hline 28 & -460 & -450 & -455 & -418 & 1378 & -457 & 5 \\
\hline 35 & -510 & -500 & -505 & -471 & 1136 & -505 & 0 \\
\hline 42 & -550 & -530 & -540 & -513 & 734 & -541 & 0 \\
\hline 49 & -590 & -570 & -580 & -549 & 947 & -571 & 84 \\
\hline 56 & -600 & -590 & -595 & -579 & 250 & -595 & 0 \\
\hline 63 & -630 & -590 & -610 & -605 & 30 & -615 & 29 \\
\hline 70 & -650 & -620 & -635 & -627 & 57 & -633 & 3 \\
\hline 77 & -670 & -640 & -655 & -648 & 54 & -649 & 38 \\
\hline 84 & -680 & -650 & -665 & -665 & 0 & -662 & 9 \\
\hline 98 & -700 & -680 & -690 & -694 & 15 & -684 & 41 \\
\hline 105 & -720 & -680 & -700 & -706 & 42 & -693 & 51 \\
\hline 112 & -720 & -680 & -700 & -717 & 304 & -701 & 1 \\
\hline 128 & -730 & -700 & -715 & -740 & 607 & -717 & 3 \\
\hline 135 & -730 & -700 & -715 & -748 & 1077 & -723 & 58 \\
\hline 144 & -750 & -720 & -735 & -758 & 517 & -730 & 28 \\
\hline 158 & -740 & -710 & -725 & -771 & 2117 & -739 & 196 \\
\hline & & & & $\sum\left(\text { Ave }-S_{t}\right)^{2}=$ & 14867 & $\sum\left(\mathrm{Ave}-S_{t}\right)^{2}=$ & 1480 \\
\hline
\end{tabular}




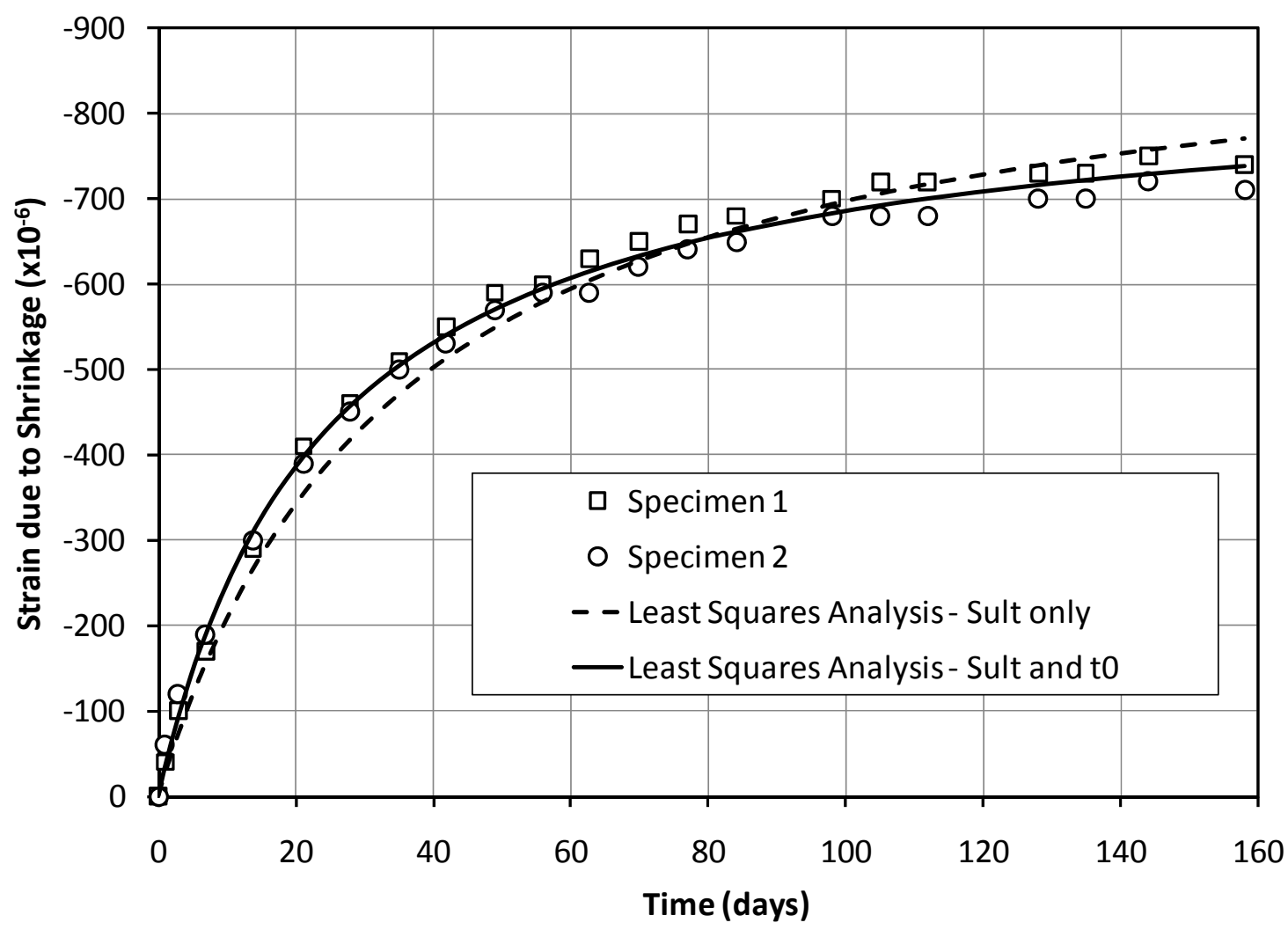

Figure 3-1: Improvement of Shrinkage Model using Least Squares Analysis for ACI209R-92 (R45-100)

An additional shrinkage model from RILEM TC-107-GCS ${ }^{56}$ uses a slightly different equation to predict shrinkage and is referred to as Model B3. The equation to predict the mean shrinkage strain in the cross section is:

$$
\varepsilon_{s h}=-\varepsilon_{s h \infty}\left(1-h^{3}\right) \tanh \left(\frac{t}{\tau_{s h}}\right)^{1 / 2}
$$

where $\varepsilon_{s h}=$ shrinkage strain in $10^{-6}$ and is considered negative, $\varepsilon_{s h \infty}=$ ultimate shrinkage strain also in $10^{-6}$ and considered negative, $\mathrm{h}=$ relative humidity of the environment expressed as a decimal, $t=$ time in days after the end of moist curing, and $\tau_{s h}=$ shrinkage half-time in days. Per RILEM TC-107-GCS, $\tau_{s h}$ is also a function of compressive strength and shape of the specimen, but was specified as a single variable for simplicity. 
Least squares regression was used in the same fashion as previously described, except that values for $\varepsilon_{s h}$ were predicted corresponding to the acquired set of data for time $t$, while changing the value of $\varepsilon_{s h \infty}$ and $\tau_{s h}$ to best fit the collected data. Results for the prediction models and relationship to experimental data are discussed in later sections. 


\section{Chapter 4 Experimental Results}

\subsection{Compressive Strength}

Table 4-1 presents a summary of test results on the mechanical properties of the hardened concrete for $f^{\prime}{ }_{c}, E_{c}$, and $E_{d}$. Only the average values of $f^{\prime}, E_{c}$, and $E_{d}$ are reported because multiple specimens were tested for each batch.

Cylinder compressive strength at 28-days is plotted against the w/c ratio of the various concrete batches using different coarse aggregates in Figure 4-1. Since w/c ratio batches of 0.30 and 0.60 were not made for RCA types RLD and RHD, these values are plotted as points on the graph. 
Table 4-1: Summary of Compressive Strength $\left(f^{\prime}\right)$ and Modulus of Elasticity $\left(E_{c}\right.$ and $\left.E_{d}\right)$

\begin{tabular}{|c|c|c|c|c|c|c|c|}
\hline \multirow{2}{*}{ Mix ID } & \multicolumn{3}{|c|}{7 days } & \multicolumn{3}{|c|}{28 days } & \multirow{2}{*}{$\begin{array}{c}90 \text { days } \\
E_{d}(\mathrm{GPa})\end{array}$} \\
\hline & $f_{c}^{\prime}(\mathrm{MPa})$ & $E_{c}(\mathrm{GPa})$ & $E_{d}(\mathrm{GPa})$ & $f_{c}^{\prime}(\mathrm{MPa})$ & $E_{c}(\mathrm{GPa})$ & $E_{d}(\mathrm{GPa})$ & \\
\hline N45-A & 35.2 & 25.3 & - & 44.4 & 27.7 & - & - \\
\hline N45-B & 37.1 & 25.3 & 36.8 & 42.8 & 28.2 & 40.0 & 42.2 \\
\hline $\mathrm{R} 45-25$ & 37.7 & 23.6 & 34.1 & 37.7 & 27.8 & 37.1 & 39.3 \\
\hline $\mathrm{R} 45-50$ & 31.8 & 25.6 & 33.9 & 39.3 & 27.2 & 36.4 & 37.8 \\
\hline R45-75 & 28.1 & 25.4 & 33.4 & 35.3 & 28.1 & 35.8 & 37.7 \\
\hline R45-100 & 33.0 & 25.7 & 32.6 & 37.6 & 28.7 & 34.5 & 36.1 \\
\hline RS45-50 & 29.9 & 22.8 & 33.6 & 35.1 & 26.0 & 36.9 & 39.0 \\
\hline RS45-100 & 30.1 & 23.8 & 34.3 & 36.3 & 26.6 & 36.9 & 38.6 \\
\hline RD45-50 & 27.2 & 22.4 & 32.0 & 33.6 & 24.5 & 35.1 & 37.3 \\
\hline RD45-100 & 28.4 & 21.7 & 30.6 & 34.4 & 23.6 & 33.5 & 35.3 \\
\hline RLD45-100 & 26.6 & 21.8 & 30.7 & 31.6 & 23.6 & 33.7 & 35.5 \\
\hline RHD45-100 & 26.1 & 20.8 & 30.8 & 34.1 & 23.3 & 34.1 & 36.3 \\
\hline N60 & 23.0 & 20.5 & 31.8 & 29.3 & 24.4 & 34.9 & 36.7 \\
\hline R60-100 & 20.4 & 21.7 & 29.7 & 27.1 & 23.9 & 32.2 & 33.4 \\
\hline RS60-100 & 20.1 & 21.2 & 30.8 & 24.9 & 23.8 & 33.9 & 35.6 \\
\hline RD60-100 & 15.1 & 17.2 & 26.9 & 20.5 & 20.1 & 30.6 & 32.4 \\
\hline N30 & 52.8 & 29.5 & 37.9 & 58.5 & 31.1 & 39.5 & 40.7 \\
\hline R30-100 & 41.3 & 28.6 & 35.4 & 45.5 & 31.3 & 37.2 & 38.6 \\
\hline RS30-100 & 49.7 & 28.8 & 37.8 & 57.1 & 30.4 & 39.5 & 40.9 \\
\hline RD30-100 & 41.5 & 24.2 & 32.8 & 47.1 & 26.2 & 34.8 & 36.5 \\
\hline
\end{tabular}

- = Not measured.

Note: $1 \mathrm{MPa}=145.0$ psi. 


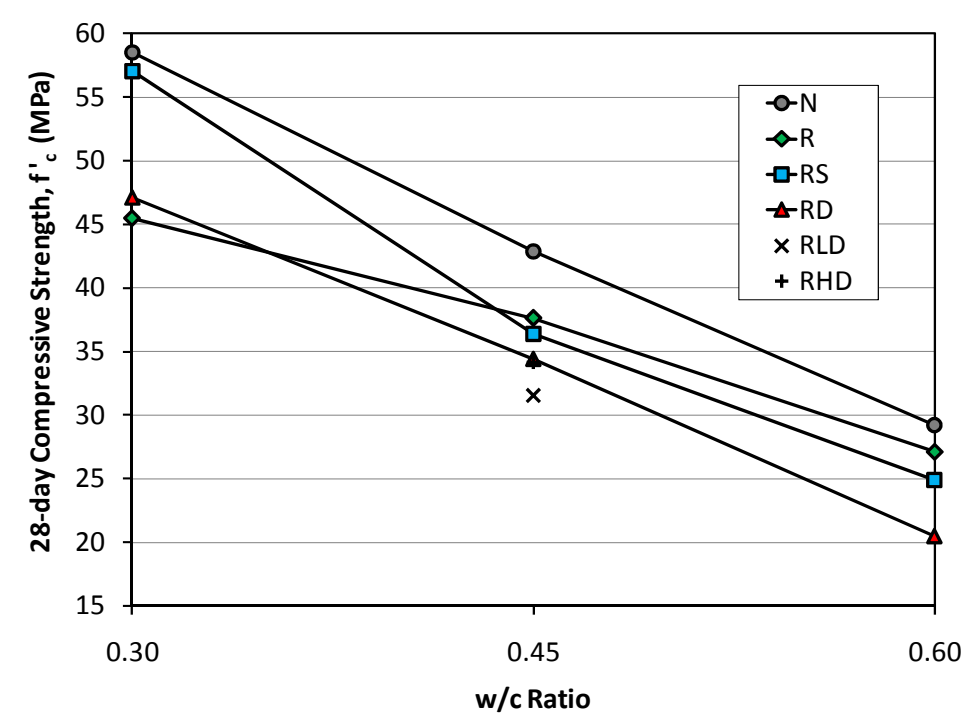

\section{Figure 4-1: Relationship Between 28-day Compressive Strength and w/c Ratio for Different Coarse Aggregates; $(100 \%$ Replacement, $1 \mathrm{MPa}=145.0 \mathrm{psi})$}

The compressive strengths of all concrete made with RCA are less than that of $f^{\prime}{ }_{c}$ associated with the control concretes for all w/c ratios. Reduction in 28-day compressive strengths for RAC compared to natural aggregate concrete ranged from $2-22 \%, 10-$ $30 \%$, and $5-30 \%$ for $0.30,0.45$, and $0.60 \mathrm{w} / \mathrm{c}$ ratio concretes, respectively. The variation in percent decrease depends on the coarse aggregate used and the level of replacement of natural coarse aggregate with RCA. These values are typical for ordinary Portland cement concretes using recycled aggregates ${ }^{1,2,5-7,12,13,20,22,24,32,47}$.

In terms of performance, RCA type R behaved the best as a substitute recycled material at $\mathrm{w} / \mathrm{c}$ ratios of 0.45 and 0.60 , and RCA type $\mathrm{RS}$ at $0.30 \mathrm{w} / \mathrm{c}$ ratio. The dried recycled aggregates in general performed the worst as a substitute material. Since RCA type RS was cured in a lime saturated bath for 30 days, additional hydration of the adhered mortar was allowed to occur, thus creating a stronger bond between old and new mortar. RCA types RD, RLD, and RHD were left to dry, and therefore the old mortar 
was weaker. RAC is weak in its early stages, but can rapidly gain strength with hydration of the old mortar ${ }^{10,23}$. Strength of RCA concrete is governed by the weaker interface between natural aggregate and adhered mortar and between the adhered mortar and the new mortar ${ }^{18,48}$. Improved strength of one aggregate over another at different $\mathrm{w} / \mathrm{c}$ ratios is attributed to the absorption of the aggregate, which directly relates to the amount of old mortar attached to the original aggregate ${ }^{1-6,9,12,13,20,22,24,33}$. Less adhered mortar on recycled aggregates improves the strength of the concrete because the old mortar of the recycled aggregates is lower in strength than that of the new mortar $5,18,24,32,33,47$

Figure 4-2 shows the relationship between $f_{c}^{\prime}$ and the coarse aggregate replacement level for 0.45 w/c concrete with RCA types R, RS, and RD. From Figure 42 , it is evident that compressive strength generally decreases with increasing levels of replacement. This trend has also been demonstrated in past studies $1,2,7,9,13,24,32,47,54$.

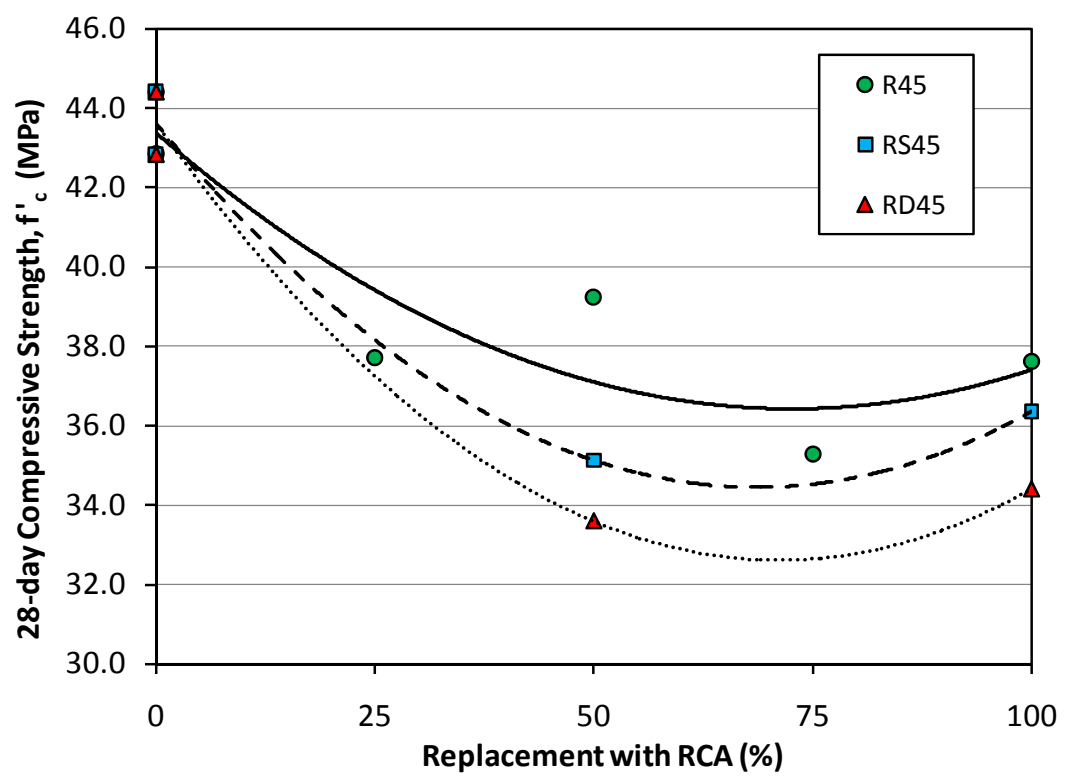

Figure 4-2: Relationship Between 28-day Compressive Strength and Increasing RCA Replacement Percentage; $(\mathrm{w} / \mathrm{c}=0.45,1 \mathrm{MPa}=145.0 \mathrm{psi})$ 
However, compressive strengths at replacement levels of 50\% were shown to be slightly less than compressive strength associated with $100 \%$ replacement for RCA types RS and RD. One factor that influences bond strength in concrete (and ultimately the compressive strength) is the surface characteristics of the aggregates ${ }^{26}$. Heterogeneity caused by differences in physical properties between aggregates is believed to cause this phenomenon. At a level of $50 \%$ replacement, $50 \%$ of the coarse aggregate are recycled and $50 \%$ are natural, creating a heterogeneous mix of coarse aggregates with dramatically different surface characteristics and material properties. Additionally, RCA have been shown to have improved bonding and interlocking characteristics over normal coarse aggregates $^{10,23}$. With $100 \%$ replacement, a homogeneous mix of recycled aggregates is developed, and the improved bonding characteristic of the RCA becomes apparent. At levels of $50 \%$ replacement, the range between values for compressive strengths was also greater than that of 0 or $100 \%$ replacement. This is also attributed to heterogeneity when mixing coarse aggregate types.

\subsection{Static Modulus of Elasticity}

Static modulus of elasticity at 28-days is plotted against the w/c ratio of the various concrete batches using different coarse aggregates in Figure 4-3. From Figure 4-3, it is evident that $E_{c}$ decreases with increasing w/c ratio. This trend is also confirmed through use of the elasticity model in examining concrete as a three-phase composite material. Using this model proposed in equation 3, relative values for the modulus of elasticity of the mortar were normalized to the $0.45 \mathrm{w} / \mathrm{c}$ ratio mix and are reported as $1.21,1.00$, and 0.81 for $0.30,0.45$, and $0.60 \mathrm{w} / \mathrm{c}$ ratio concrete mixes, respectively. 


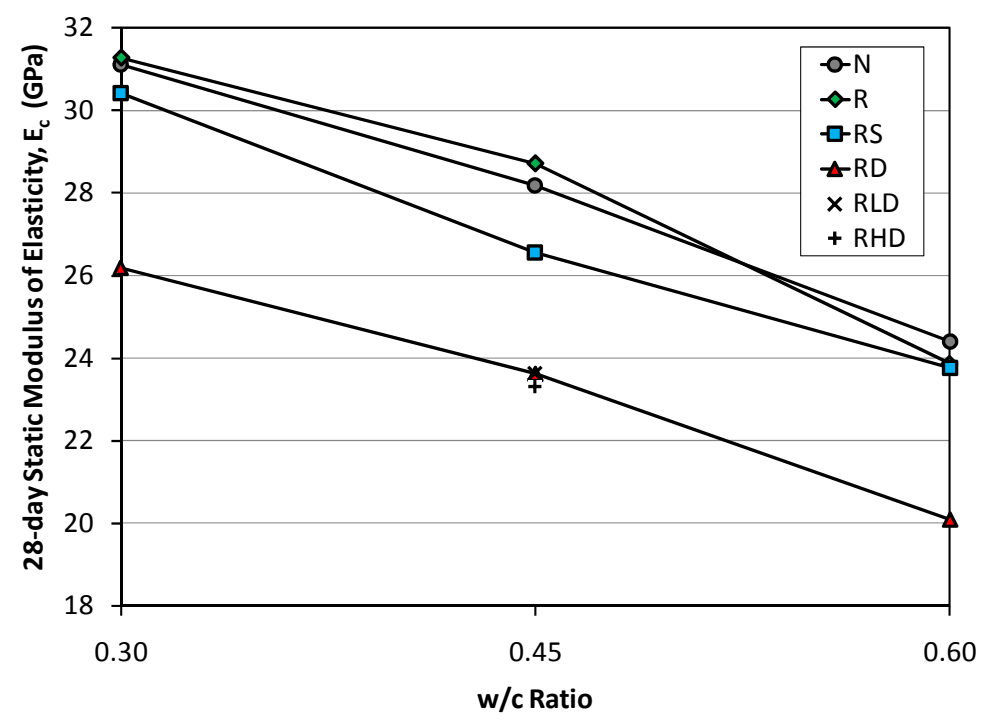

Figure 4-3: Relationship Between 28-day Static Modulus of Elasticity and w/c Ratio for Different Coarse Aggregates; (100\% Replacement, 1 GPa $=145.0 \mathrm{ksi})$

Clearly, the value of the elasticity of each mortar contributes to the overall static modulus of elasticity of the concrete. Additionally, $E_{c}$ is directly proportional to the square root of the compressive strength, as displayed in equations 4 and 5. Since each concrete mix was maintained at relatively constant water content, addition of cement to change the w/c ratio makes the lower $\mathrm{w} / \mathrm{c}$ concrete batches stronger. In comparison to the control concretes, Figure 4-3 depicts RCA type R concretes having a slightly larger value for $E_{\mathrm{c}}$, RCA type RS concretes having a slightly smaller value for $E_{\mathrm{c}}$, and RCA type RD, RLD, and RHD concretes having much lower values for $E_{\mathrm{c}}$. These trends are confirmed by examining the relative values of the modulus of elasticity of the coarse aggregates predicted using the three-phase logarithmic mixture rule for modeling elasticity in concrete, as specified in equation 3. Predicted values for elasticity of the various coarse aggregates were normalized to the natural coarse aggregate and are reported as 1.00 , 
1.04, 0.92, 0.63, 0.66, and 0.64 for RCA types N, R, RS, RD, RLD, and RHD, respectively.

Comparing the normalized values for the elastic modulus of the aggregates to trends in Figure 4-3 indicates that $E_{c}$ is dependent on the elastic modulus of the aggregate. Previous studies $1,2,7,9,13,14,23,32,47,54$ show that $E_{c}$ values for RAC are $55-100 \%$ of that of natural concrete. This is attributed to the predicted lower elastic modulus of the recycled coarse aggregates ${ }^{14,23,47}$. In this experimental study, $E_{c}$ for recycled concrete was $0-20 \%$ lower than that of the control concretes.

Relationships between $E_{c}$ and level of percent replacement for $0.45 \mathrm{w} / \mathrm{c}$ concrete with RCA types R, RS, and RD are shown in Figure 4-4. Also plotted in this figure are the $E_{c}$ curves predicted using the developed elasticity model. In general, $E_{c}$ decreases with increasing percent replacement with RCA. However, due to the greater stiffness of RCA type R, $E_{c}$ actually increases for concrete mixes with RCA type R at $100 \%$ replacement.

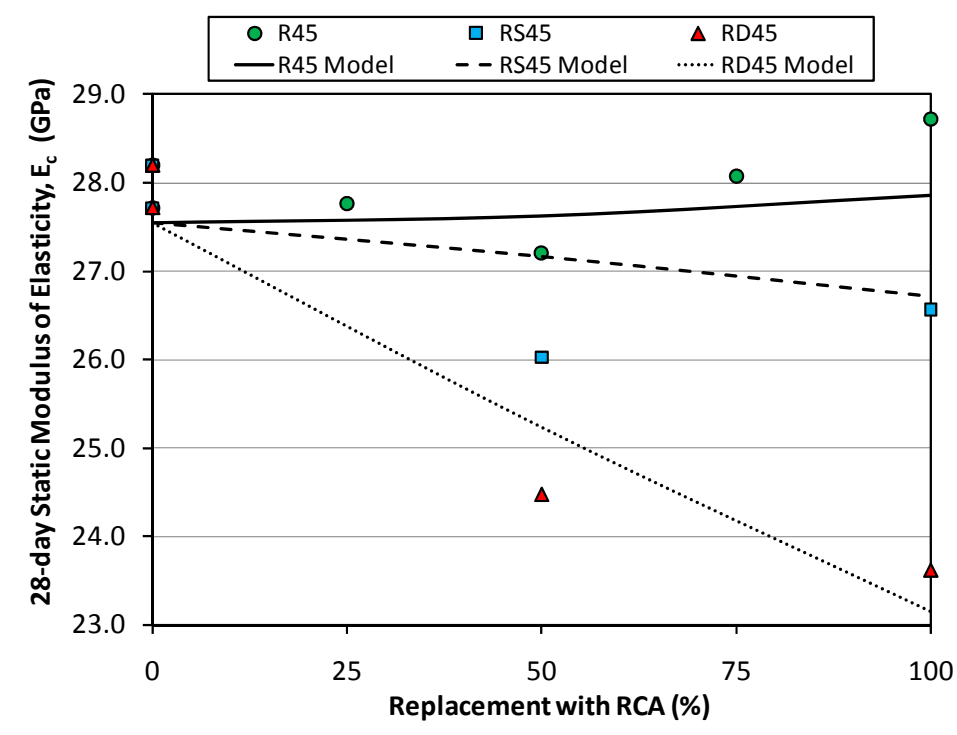

Figure 4-4: Relationship Between 28-day Static Modulus of Elasticity and Increasing RCA Replacement Percentage; $(w / c=0.45,1$ GPa $=145.0 \mathrm{ksi})$ 
Examining the model curves, it's evident that the model predicts a linear trend for $E_{c}$ based on elasticity of the individual aggregates. Regardless of the selected starting value for the natural aggregate, the model predicted the same values for $E_{c}$ at different percent replacements. Additionally, both RCA types R and RS show a trend of increasing $E_{c}$ after $50 \%$ replacement of recycled material. The elastic modulus of the concrete increases due to RCA having improved bonding and interlocking characteristics ${ }^{10,23}$, as well as the hydration of old mortar in the $\mathrm{RCA}^{32}$. For poorer quality aggregates, such as RCA types RD, RLD, and RHD, this increase in $E_{c}$ past $50 \%$ RCA replacement does not occur, and the largest difference between $E_{c}$ of the control concrete and $E_{c}$ for these RCA types occurs at $100 \%$ replacement. Previous studies performed using different levels of RCA replacement support these trends with the poorer quality aggregates ${ }^{7,9,13,14,20,32,47,54}$.

\subsection{Dynamic Modulus of Elasticity}

Dynamic modulus of elasticity at 90 -days is also plotted against the w/c ratio of the concrete batches using different coarse aggregates in Figure 4-5. As with $E_{c}$, Figure 4-5 shows that in general, $E_{d}$ decreases with increasing w/c ratio. This is likely attributed to weaker mortar from higher w/c concretes; weaker mortar allows for more microcracking to occur $^{48}$. Under induced vibrations, presence of micro-cracks leads to lower resonant frequencies, and thus lower values for the dynamic modulus ${ }^{58}$. As expected, natural coarse aggregate concretes exhibit the largest values for $E_{d}$. Comparing $E_{c}$ to $E_{d}$ at 28-days shows that $E_{d}$ is much larger than $E_{c}$. This is due to viscoelastic effects ${ }^{59}$ when testing $E_{c}$ versus $E_{d}$. Since $E_{d}$ is tested using a much faster load rate (vibration excitation), the resulting $E_{d}$ is larger than that of $E_{c}$, which is tested at a slower constant load rate. 


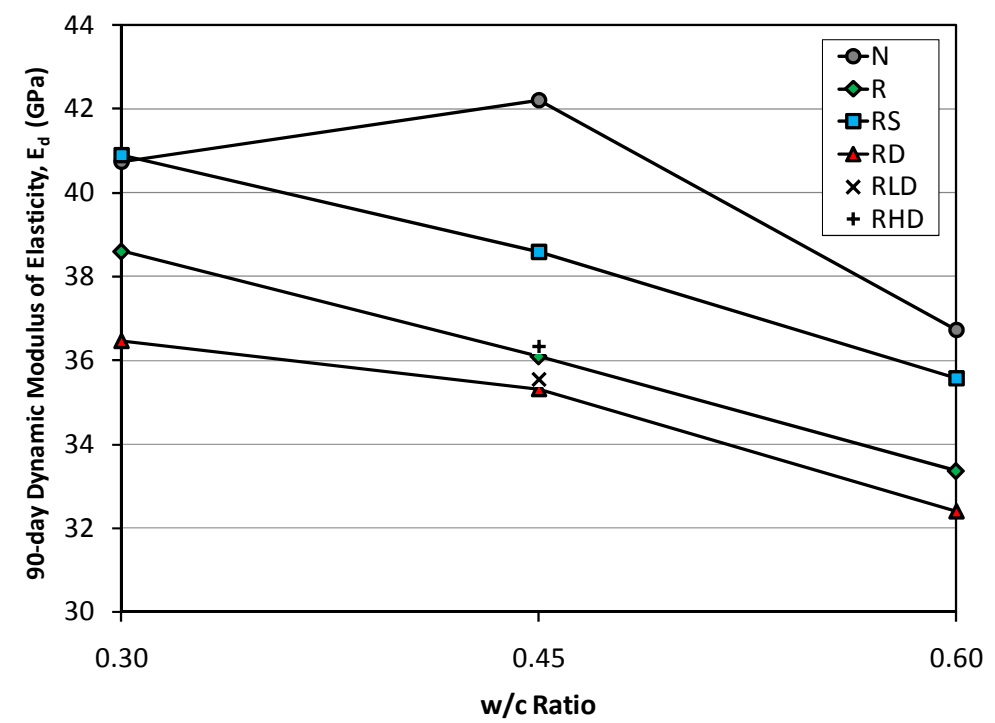

Figure 4-5: Relationship Between 90-day Dynamic Modulus of Elasticity and w/c Ratio for Different Coarse Aggregates; (100\% Replacement, 1 GPa $=145.0 \mathrm{ksi})$

The value of $E_{d}$ for N30 is less than the value of $E_{d}$ for N45, which can be attributed to lack of water at the interfacial transition zone (ITZ) in the $0.30 \mathrm{w} / \mathrm{c} \mathrm{concrete}^{48}$. In terms of dynamic properties of the concrete, RCA type RS showed the best performance next to natural aggregate as it had the largest $E_{d}$ of all RACs. Since modulus of elasticity of concrete is directly related to modulus of elasticity of its aggregates ${ }^{14,23,47}$, it can be theorized that RCA type RS has a larger $E_{d}$ than the other RCAs. The improved dynamic performance of RCA type RS can be attributed to the 30 days of moist curing. This moist curing allows for additional hydration to occur on the old mortar, thus creating a stronger ITZ. A stronger ITZ results in less micro-cracking, and fewer micro-cracks attributes to the larger values of $E_{d}$ achieved in this particular RAC. Although RCA type R showed the greatest stiffness compared to other RCA, the quality of mortar attached to RCA type $\mathrm{R}$ is likely less than that of the mortar attached to RCA type RS, and as a result RCA type R displayed the next largest values for $E_{d}$. Figure 4-5 shows the dried RCA to have the 
lowest values for $E_{d}$. Dried aggregate has less water at the ITZ, therefore resulting in increased micro-cracking ${ }^{48}$ and lower values for $E_{d}{ }^{58}$. For this experimental study, $E_{d}$ values for RAC were $5-15 \%$ less than that of natural concrete.

The 90-day $E_{d}$ is plotted against the percent replacement of RCA for $0.45 \mathrm{w} / \mathrm{c}$ concrete batches in Figure 4-6, which shows that increasing the percent of RCA decreases $E_{d}$. This trend is supported by many studies that examine the effects of different levels of RCA on the modulus of elasticity of concrete , $9,13,14,20,25,47,54^{\text {. With }}$ increasing percentage of RCA, the amounts of old mortar increases as well. Since old mortar is prone to micro-cracking ${ }^{48}$, lower values for $E_{d}$ are recorded with increased percent replacement of RCA. From Figure 4-6, it is apparent that RCA type RS displays the best dynamic properties, followed by RCA types R then RD.

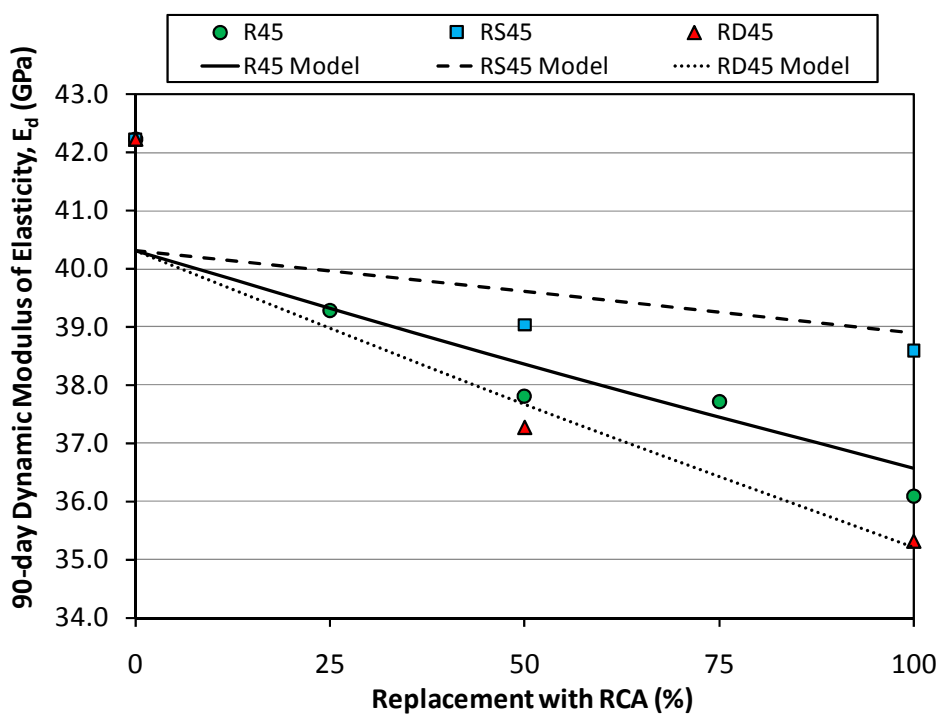

\section{Figure 4-6: Relationship Between 90-day Dynamic Modulus of Elasticity and Increasing RCA Replacement Percentage; $(w / c=0.45,1$ GPa $=145.0 \mathrm{ksi})$}

Examining the model curves, it's evident that the model predicts a linear trend for $E_{d}$ based on elasticity of the individual aggregates. Regardless of the selected starting value 
for the natural aggregate, the model predicted the same values for $E_{d}$ at different percent replacements.

Table 4-2 reports values for the progression of $E_{d}$ with age. The $E_{d}$ values reported are the averages of the two specimens from each batch. All necessary information used to calculate $E_{d}$, such as mass and dimension properties and longitudinal frequency, are located in Appendix B - Prismatic Beam Records.

Table 4-2: Progression of $E_{d}$ with Age

\begin{tabular}{lccccccc}
\hline \hline & \multicolumn{7}{c}{ Average $E_{d}(\mathrm{GPa})$} \\
\cline { 2 - 7 } Mix ID & 1-day & 3-days & 7-days & 14-days & 28-days & 60 -days & 90 -days \\
\hline \hline N45-B & 25.7 & 34.0 & 36.8 & 38.4 & 40.0 & 41.4 & 42.2 \\
R45-25 & 24.4 & 31.3 & 34.1 & 35.7 & 37.1 & 38.4 & 39.3 \\
R45-50 & - & 31.6 & 33.9 & 35.1 & 36.4 & - & 37.8 \\
R45-75 & 24.5 & 30.9 & 33.4 & 34.5 & 35.8 & 36.9 & 37.7 \\
R45-100 & 25.0 & 30.2 & 32.6 & 33.3 & 34.5 & - & 36.1 \\
RS45-50 & 22.9 & 30.9 & 33.6 & 35.0 & 36.9 & 38.4 & 39.0 \\
RS45-100 & 24.9 & 32.2 & 34.3 & 35.5 & 36.9 & 38.2 & 38.6 \\
RD45-50 & 20.6 & 29.3 & 32.0 & 33.8 & 35.1 & 36.5 & 37.3 \\
RD45-100 & 19.7 & 28.2 & 30.6 & 32.2 & 33.5 & 34.8 & 35.3 \\
RLD45-100 & 19.5 & 28.6 & 30.7 & 32.3 & 33.7 & 34.8 & 35.5 \\
RHD45-100 & 21.9 & 28.0 & 30.8 & 32.6 & 34.1 & 35.7 & 36.3 \\
N60 & 21.4 & 28.3 & 31.8 & 33.2 & 34.9 & 36.1 & 36.7 \\
R60-100 & 19.9 & 27.1 & 29.7 & 31.2 & 32.2 & 33.2 & 33.4 \\
RS60-100 & 22.6 & 27.7 & 30.8 & 32.3 & 33.9 & 34.8 & 35.6 \\
RD60-100 & 18.6 & 24.0 & 26.9 & 28.8 & 30.6 & 31.6 & 32.4 \\
N30 & 32.2 & 36.5 & 37.9 & 39.0 & 39.5 & 40.3 & 40.7 \\
R30-100 & 30.2 & 34.3 & 35.4 & 36.5 & 37.2 & 38.1 & 38.6 \\
RS30-100 & 33.2 & 36.0 & 37.8 & 38.7 & 39.5 & 40.4 & 40.9 \\
RD30-100 & 26.7 & 30.9 & 32.8 & 34.0 & 34.8 & 35.9 & 36.5 \\
\hline \hline
\end{tabular}

- = Not measured.

Note: $1 \mathrm{GPa}=145.0 \mathrm{ksi}$. 


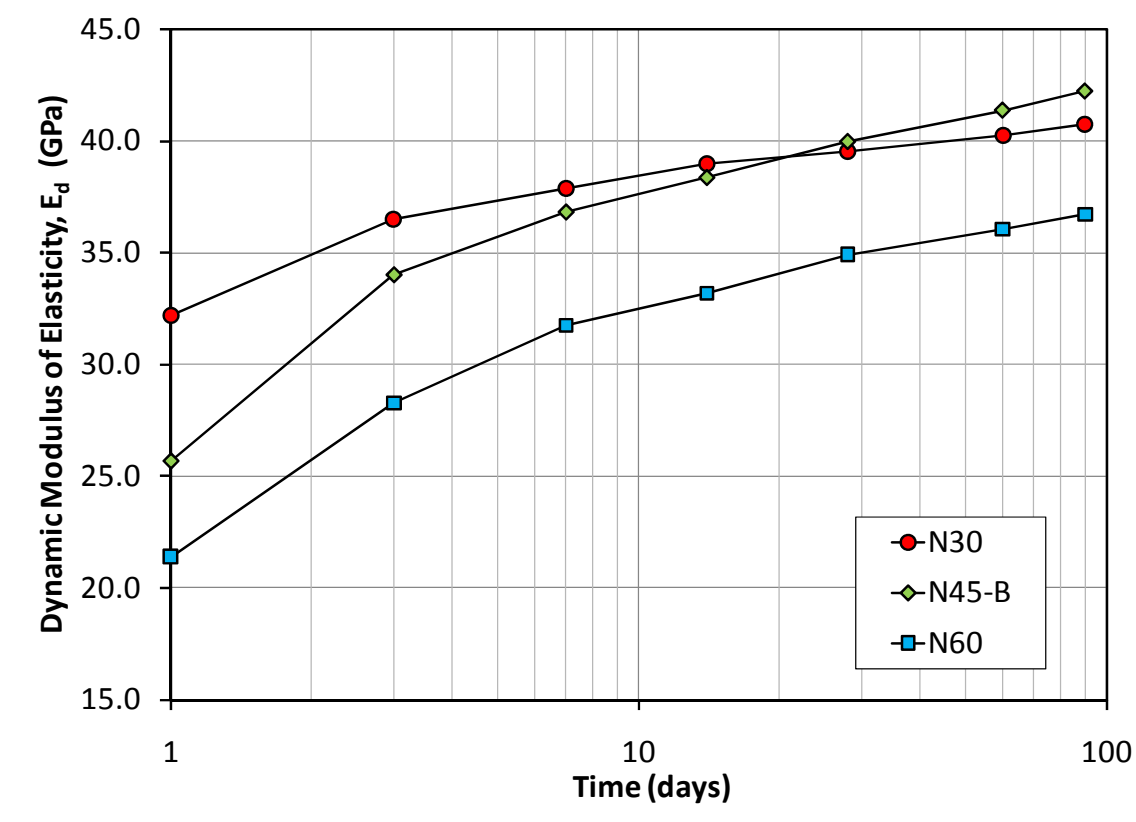

Figure 4-7: Development of $E_{d}$ with Age (Control Concretes)

Development of dynamic modulus of elasticity with age was examined to see how different coarse aggregates and/or w/c ratios affect $E_{d}$ with age. Figure 4-7 shows the development of $E_{d}$ over time for the control concretes. At early ages, the relationship between $E_{d}$ and w/c ratio is inversely proportional, meaning lower w/c ratios create larger values for $E_{d}$. However, at approximately 20 -days, the $0.45 \mathrm{w} / \mathrm{c}$ control concrete $E_{d}$ value begins to exceed that of the $0.30 \mathrm{w} / \mathrm{c}$ control concrete. Less water at the ITZ results in increased micro-cracking, and due to the greater hydration demands of the $0.30 \mathrm{w} / \mathrm{c}$ concrete, the value of $E_{d}$ ultimately begins to decrease in comparison to higher w/c ratio concretes. 
Figures 4-8 to 4-10 depict the development of $E_{d}$ for concretes using recycled aggregates in comparison to the control concretes for the three w/c ratios. In general, $E_{d}$ values for the control concrete are greater than that of the RAC at all ages; with the exception of RCA type RS at $0.30 \mathrm{w} / \mathrm{c}$ ratio. The improved dynamic performance of RCA type RS is due to the 30 days of moist curing which allowed for additional hydration of the old mortar. This leads to improved at the ITZ between the old mortar and the aggregate as well as the new mortar and the RCA. Further observation of these figures shows that the difference between $E_{d}$ values for different coarse aggregates remains relatively constant over time. Figure 4-9 in particular shows that concretes with dried RCA performed equally despite differences in initial w/c ratio parent concretes. This is likely due to the early age at which the parent concretes were broken apart and the drying process of the RCA.

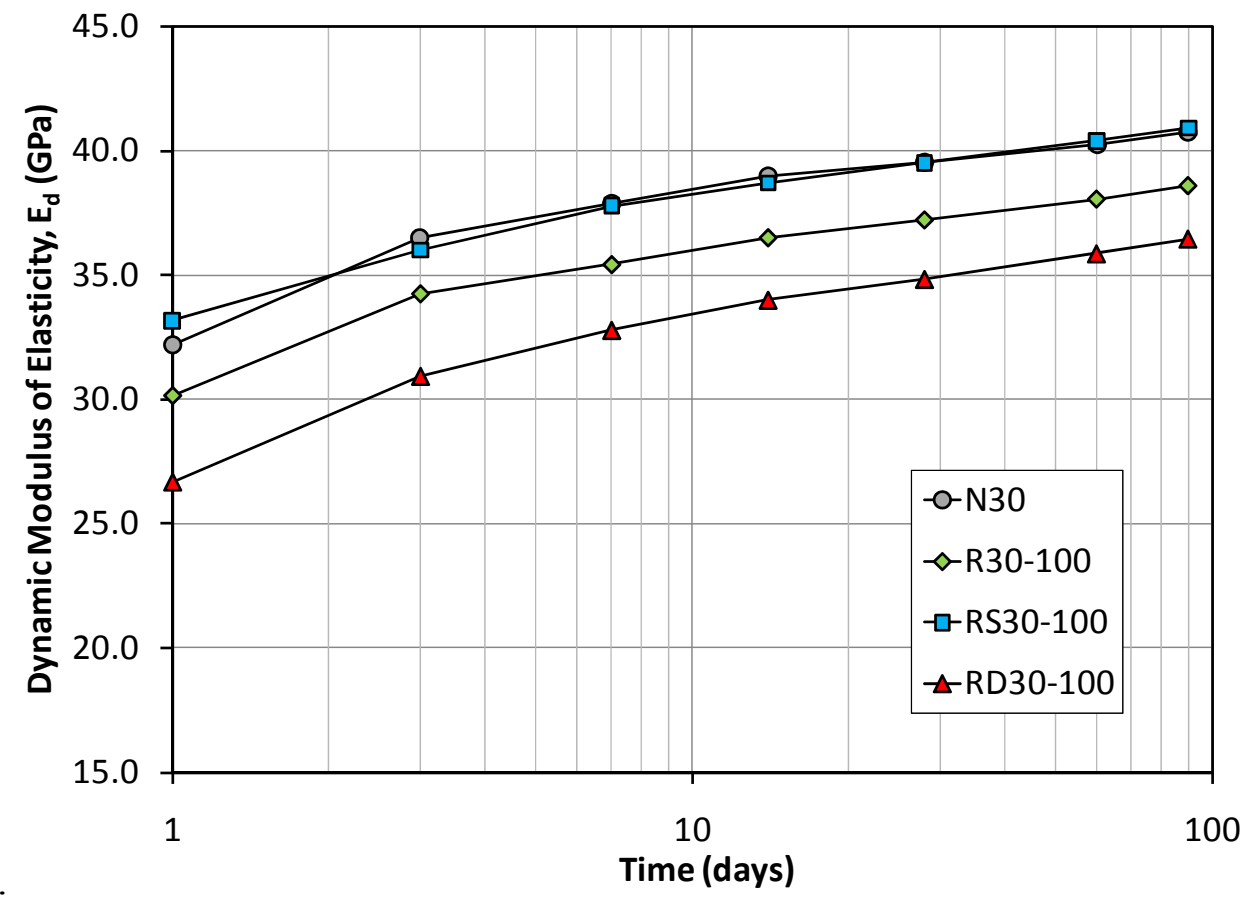

Figure 4-8: Development of $E_{d}$ with Age $(w / c=0.30)$ 


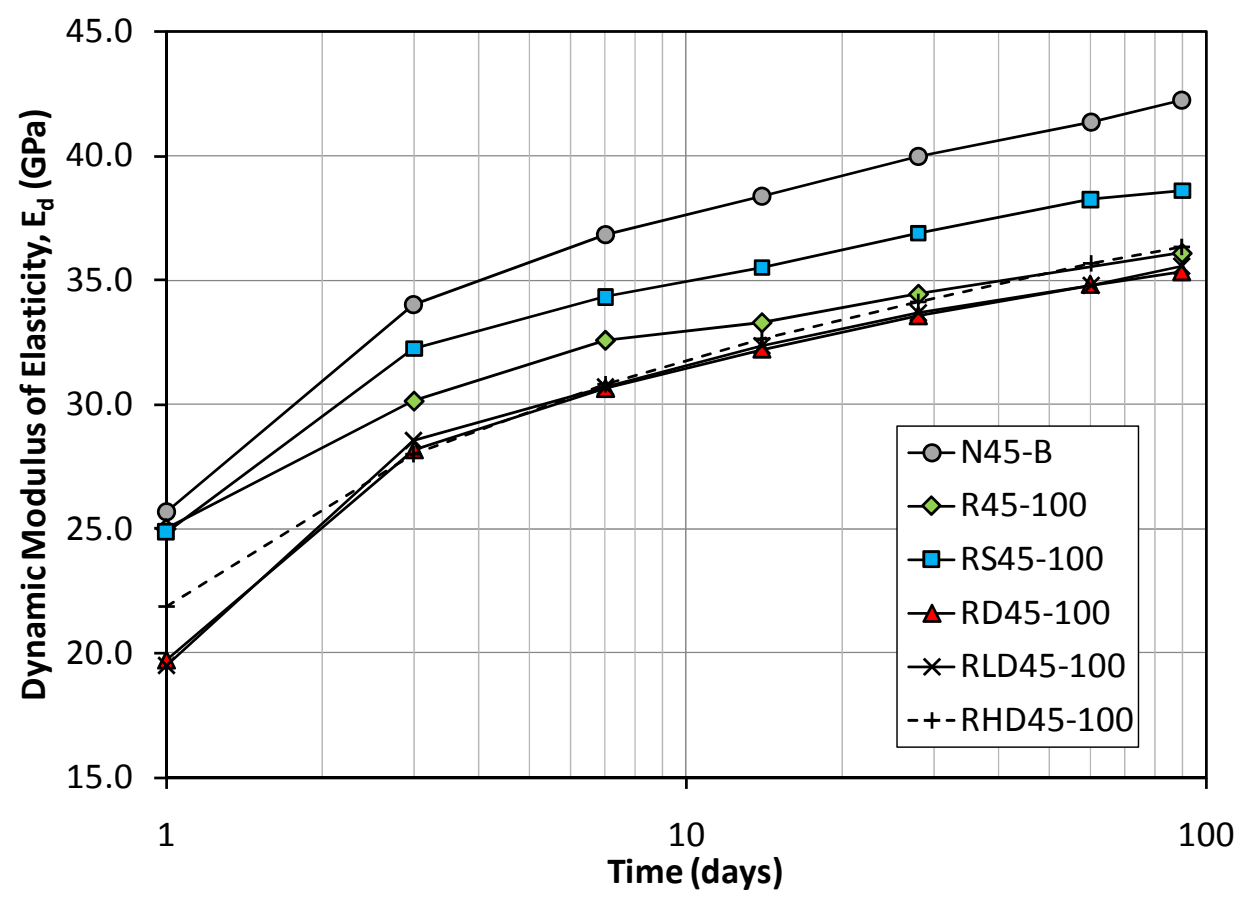

Figure 4-9: Development of $E_{d}$ with Age $(w / c=0.45)$

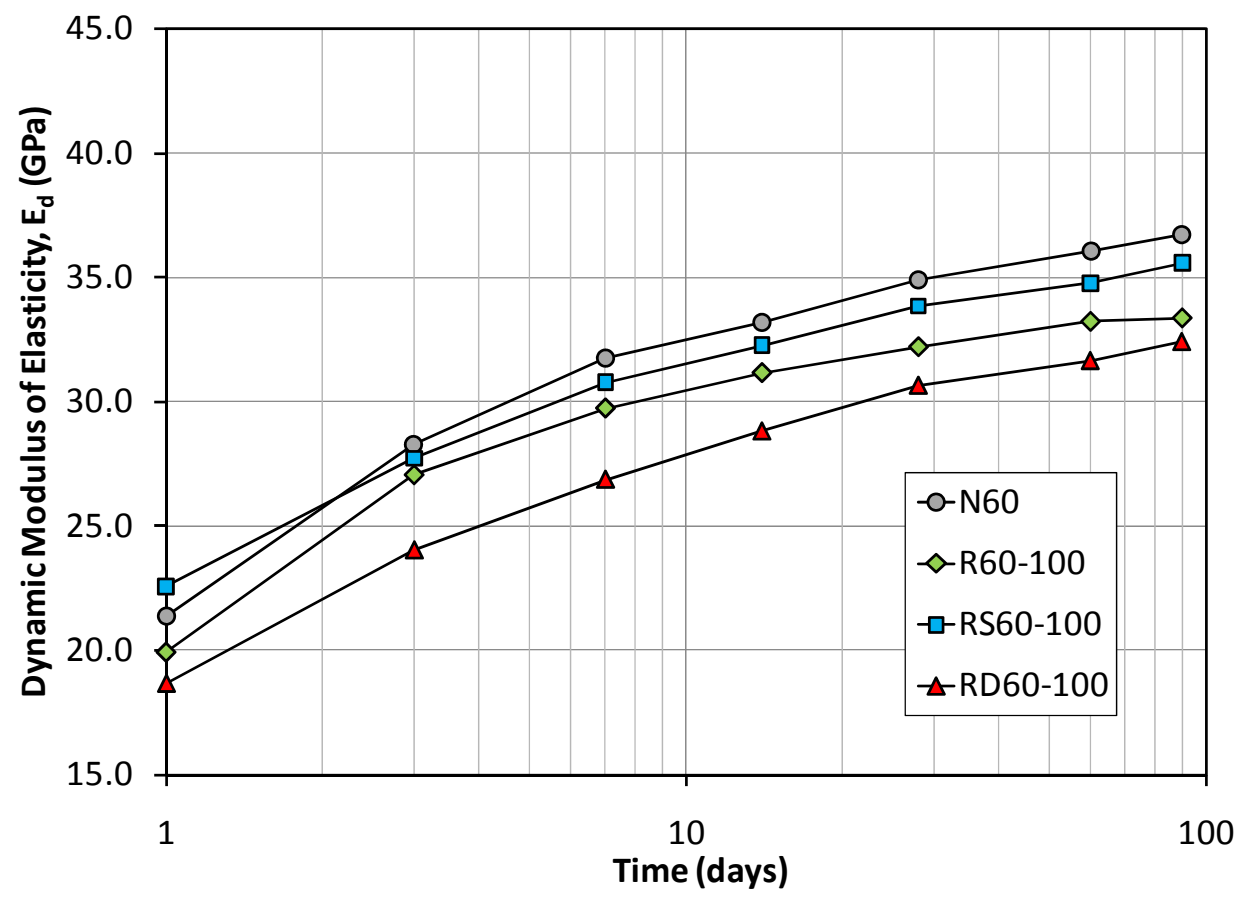

Figure 4-10: Development of $E_{d}$ with Age $(w / c=0.60)$ 
Figures 4-11 through 4-13 show the development of $E_{d}$ for the same types of RCA at different w/c ratios. One notable trend for all figures is that the difference between $E_{d}$ values decreases over time despite the concretes having different $\mathrm{w} / \mathrm{c}$ ratios. It is possible that these values would ultimately converge to a single $E_{d}$ value or that the $E_{d}$ of $0.30 \mathrm{w} / \mathrm{c}$ concretes would become less than that of the 0.45 and $0.60 \mathrm{w} / \mathrm{c}$ concretes as previously observed with the control concretes. However, validation of these statements would require additional testing.

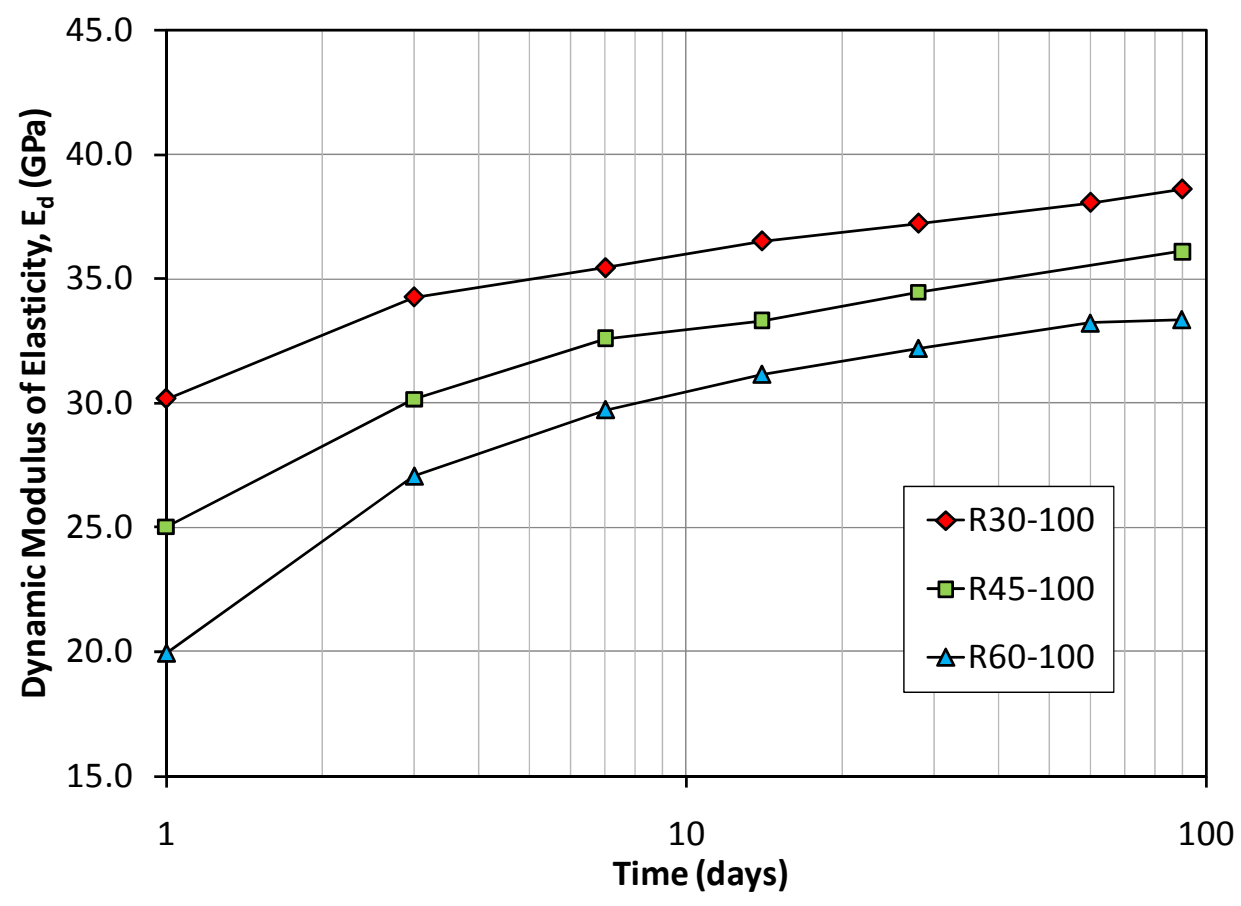

Figure 4-11: Development of $E_{d}$ with Age (100\% RCA type R) 


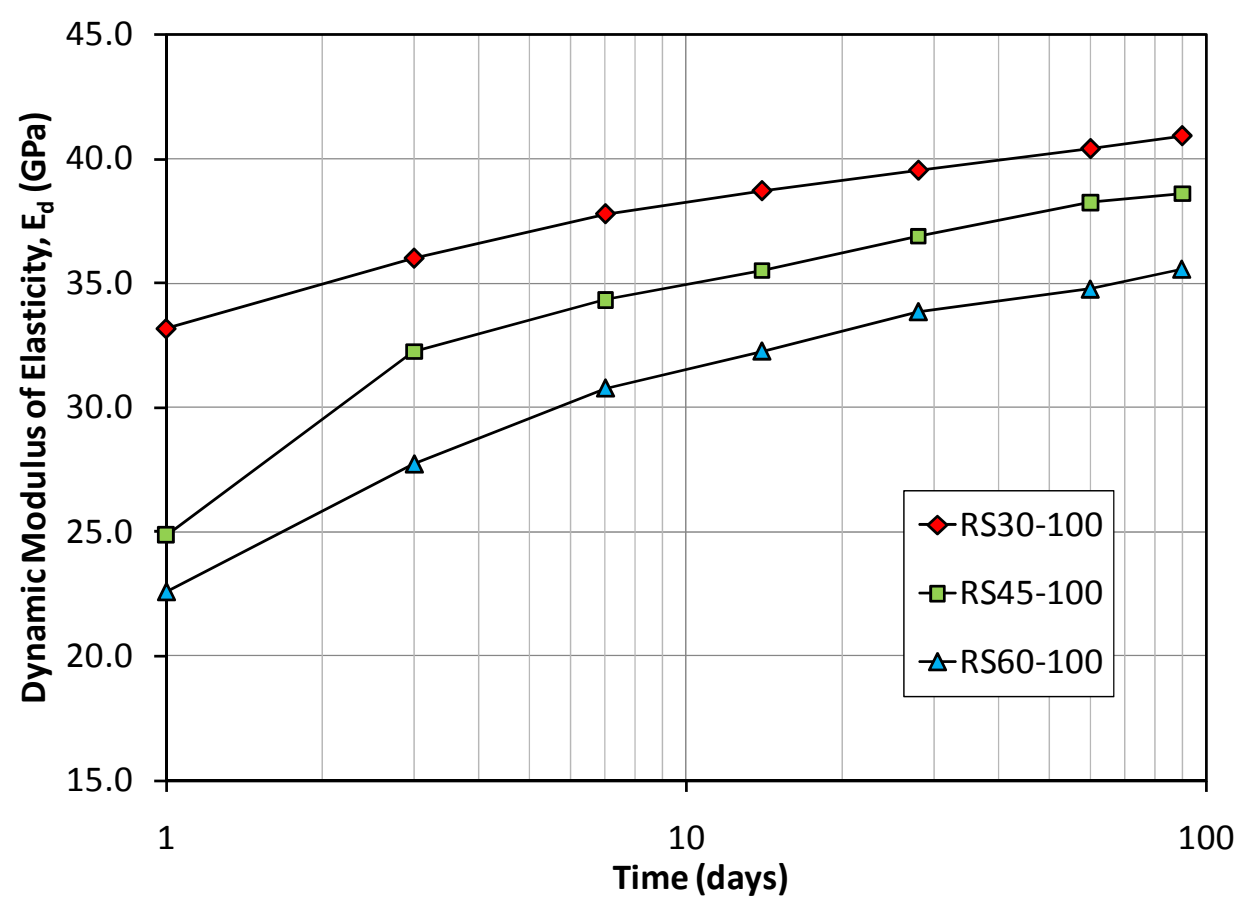

Figure 4-12: Development of $E_{d}$ with Age (100\% RCA type RS)

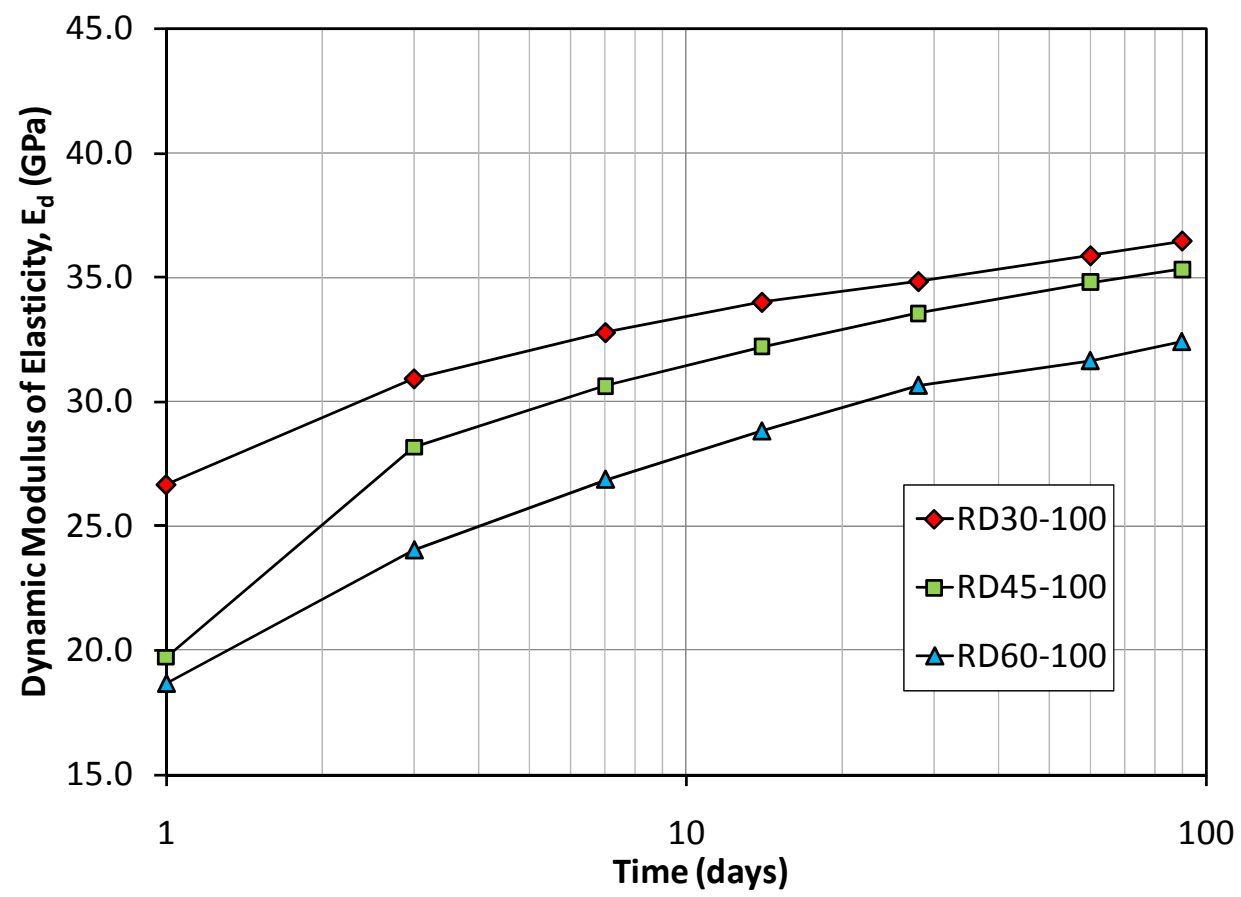

Figure 4-13: Development of $E_{d}$ with Age (100\% RCA type RD) 
Experimental testing for dynamic modulus of elasticity reveals that increasing the percent of recycled aggregates in concrete decreases the value of $E_{d}$. Figure 4-14 shows this statement to be valid for RCA type R at all ages of testing. Additionally, the difference between $E_{d}$ increases with age for increasing percentages of RCA. Previous studies indicate that recycled aggregates have a greater porosity than natural aggregates due the presence of adhered mortar ${ }^{3,6,7,15,18,32,33}$. This increased porosity leads to greater variation within the microstructure of the concrete and ultimately a weaker ITZ ${ }^{48}$. This weaker ITZ results in increased micro-cracking which in turn causes a lower resonant frequency and a lower value for dynamic modulus of elasticity ${ }^{58}$.

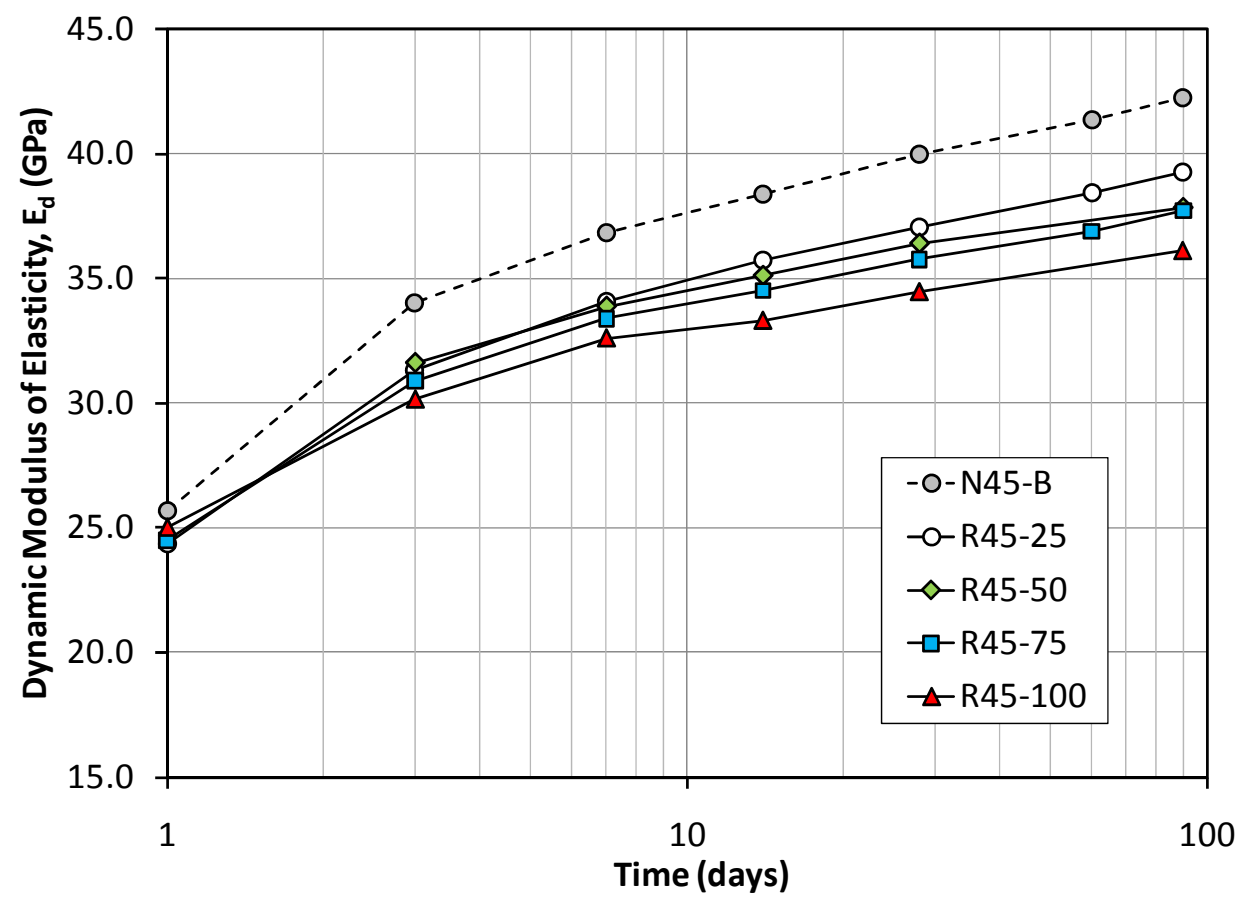

Figure 4-14: Development of $E_{d}$ with Age (0 - 100\% RCA type R) 
Figure 4-15 below examines the relationship between the ratios of $E_{c}$ to $E_{d}$ for increasing replacement of natural aggregate with RCA.

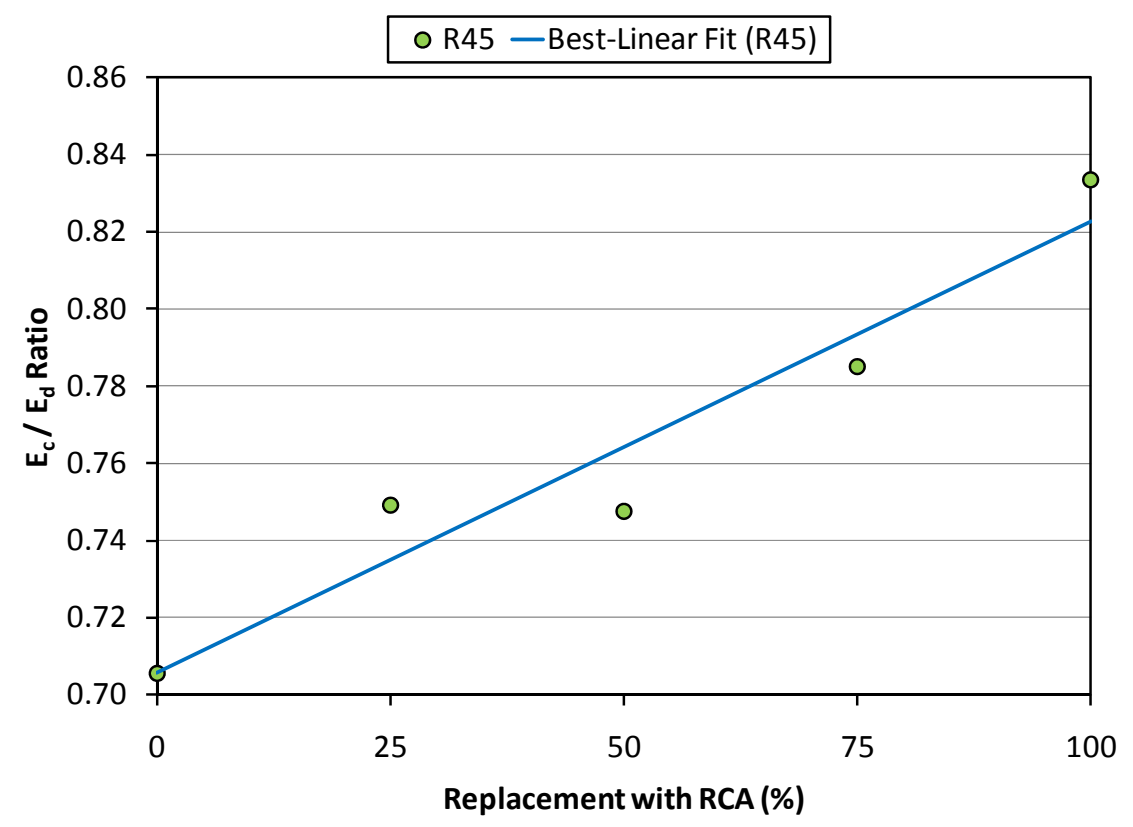

Figure 4-15: Examining $E_{c} / E_{d}$ Ratio with Increasing Levels of RCA type R

This increasing ratio with increasing percent replacement is only observed for RCA type $\mathrm{R}$ and occurs due to the increasing values of $E_{c}$ (Figure 4-4) and decreasing values of $E_{d}$ (Figure 4-6). In this particular study, $E_{c}$ was on average $20-30 \%$ lower than $E_{d}$, which is to be expected based on previous research ${ }^{22,26}$.

Both static and dynamic moduli of elasticity are plotted as a function of compressive strength in Figure 4-16 for concrete batches with 100\% replacement of RCA. This data is compared to $E_{c}$ values predicted by ACI $318-08^{50}$ (equation 5), and to $E_{c}$ and $E_{d}$ values predicted by Ravindrarajah and $\operatorname{Tam}^{22}$ (equations 6 and 7, respectively). Using the general expression $E_{i}=\mathrm{A}\left(f^{\prime}{ }^{\prime}\right)^{\mathrm{B}}$, values for $\mathrm{A}$ and $\mathrm{B}$ were changed using least squares regression to best predict $E_{c}$ and $E_{d}$ values from this study. 


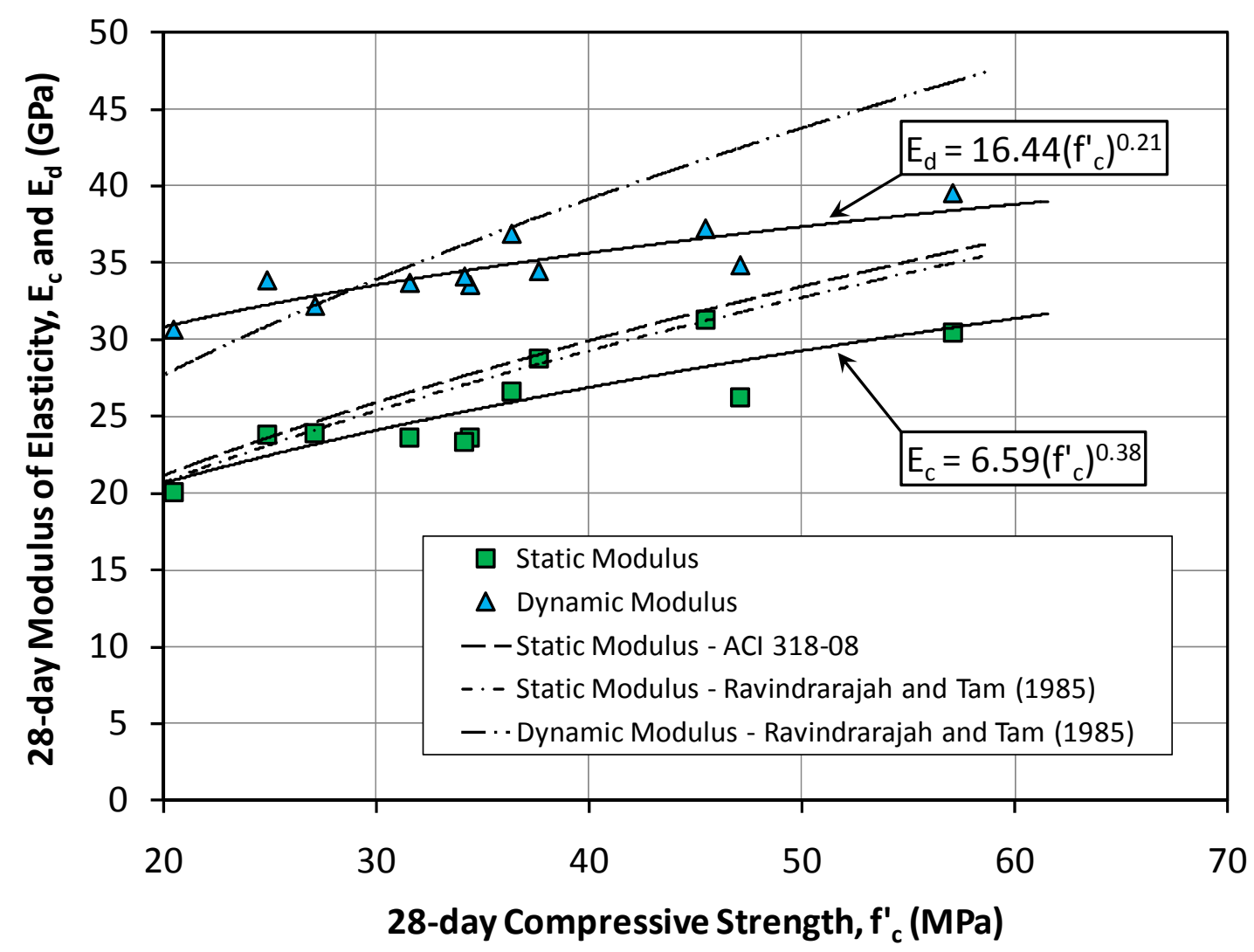

Figure 4-16: Modulus of Elasticity as a Function of Compressive Strength for Concrete Made w/ 100\% RCA; 1 MPa $=145.0$ psi

Following the general expression, the resulting equations are shown below:

$$
\begin{aligned}
& E_{c}=6.59\left(f^{\prime}{ }_{c}\right)^{0.38} \\
& E_{d}=16.44\left(f^{\prime}{ }_{c}\right)^{0.21}
\end{aligned}
$$

where $E_{c}$ and $E_{d}$ are the static and dynamic modulus of elasticity in GPa, and $f^{\prime}{ }_{c}$ is the compressive strength in MPa. Equations 10 and 11 show that values for $E_{c}$ and $E_{d}$ in this study are predicted to be lower than that from previous models (ACI 318-08 and Ravindrarajah and Tam). 


\subsection{Drying Shrinkage}

Table 4-3 presents a summary of test results for the predicted shrinkage half-time and ultimate shrinkage for the two shrinkage models used in this study. These values were obtained using least squares analysis following the example in Section 3.2.

Table 4-3: Prediction of Ultimate Shrinkage $\left(S_{\text {ult }}\right.$ and $\left.\varepsilon_{\text {sh }}\right)$ Using ACI-209R-92 and RILEM TC-107-GCS Model B3

\begin{tabular}{lcc|cc}
\hline \hline \multirow{2}{*}{ Mix ID } & \multicolumn{2}{c|}{ ACI 209R-92 } & \multicolumn{2}{c}{ Model B3 } \\
\cline { 2 - 5 } & $t_{0}$, days & $S_{u l t}\left(\times 10^{-6}\right)$ & $\tau_{\text {sh }}$, days & $\varepsilon_{\text {sho }}\left(\times 10^{-6}\right)$ \\
\hline \hline N45-A & 16.9 & -697 & 62.1 & -804 \\
N45-B & 18.4 & -637 & 61.9 & -721 \\
R45-25 & 22.9 & -704 & 79.0 & -805 \\
R45-50 & 21.2 & -819 & 75.5 & -946 \\
R45-75 & 23.0 & -709 & 79.3 & -812 \\
R45-100 & 24.1 & -852 & 81.6 & -974 \\
RS45-50 & 24.1 & -789 & 91.4 & -930 \\
RS45-100 & 24.3 & -874 & 90.6 & -1025 \\
RD45-50 & 21.4 & -789 & 78.0 & -916 \\
RD45-100 & 22.9 & -911 & 85.4 & -1067 \\
RLD45-100 & 19.7 & -889 & 71.2 & -1026 \\
RHD45-100 & 23.1 & -810 & 88.6 & -959 \\
N60 & 17.9 & -685 & 60.5 & -777 \\
R60-100 & 21.0 & -773 & 70.1 & -876 \\
RS60-100 & 25.7 & -929 & 97.8 & -1098 \\
RD60-100 & 25.5 & -855 & 95.7 & -1005 \\
N30 & 17.1 & -689 & 55.9 & -775 \\
R30-100 & 44.2 & -844 & 253.8 & -1181 \\
RS30-100 & 24.1 & -777 & 91.2 & -914 \\
RD30-100 & 19.1 & -871 & 66.9 & -996 \\
\hline \hline
\end{tabular}


Figures 4-17 through 4-20 depict the drying shrinkage curves for $0.30,0.45$, and $0.60 \mathrm{w} / \mathrm{c}$ ratio concretes with $100 \%$ natural or recycled aggregates. Strain is plotted and presented as a negative value to imply negative volume change of the shrinkage specimen. In general, these curves show that the presence of RCA in concrete leads to increased shrinkage, as was the case in previous studies ${ }^{1,2,7-9,19,22,24,25,32,53-55}$. Both natural and recycled coarse aggregates display similar rates of shrinkage development at an early age, but after a certain length of time concrete with natural coarse aggregate appears to stop shrinking while concrete with RCA continues to shrink.

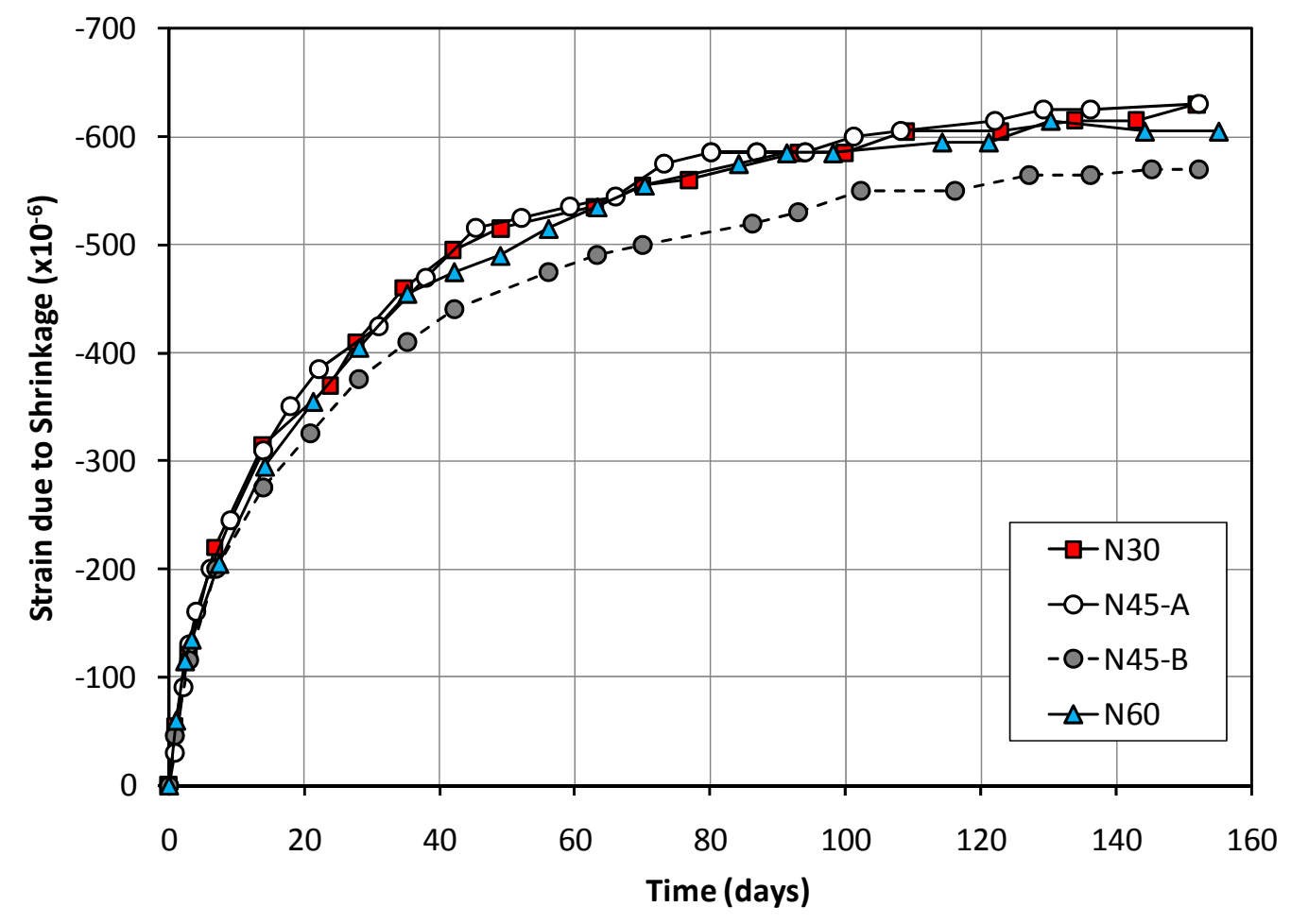

Figure 4-17: Drying Shrinkage Curves for Control Concretes 


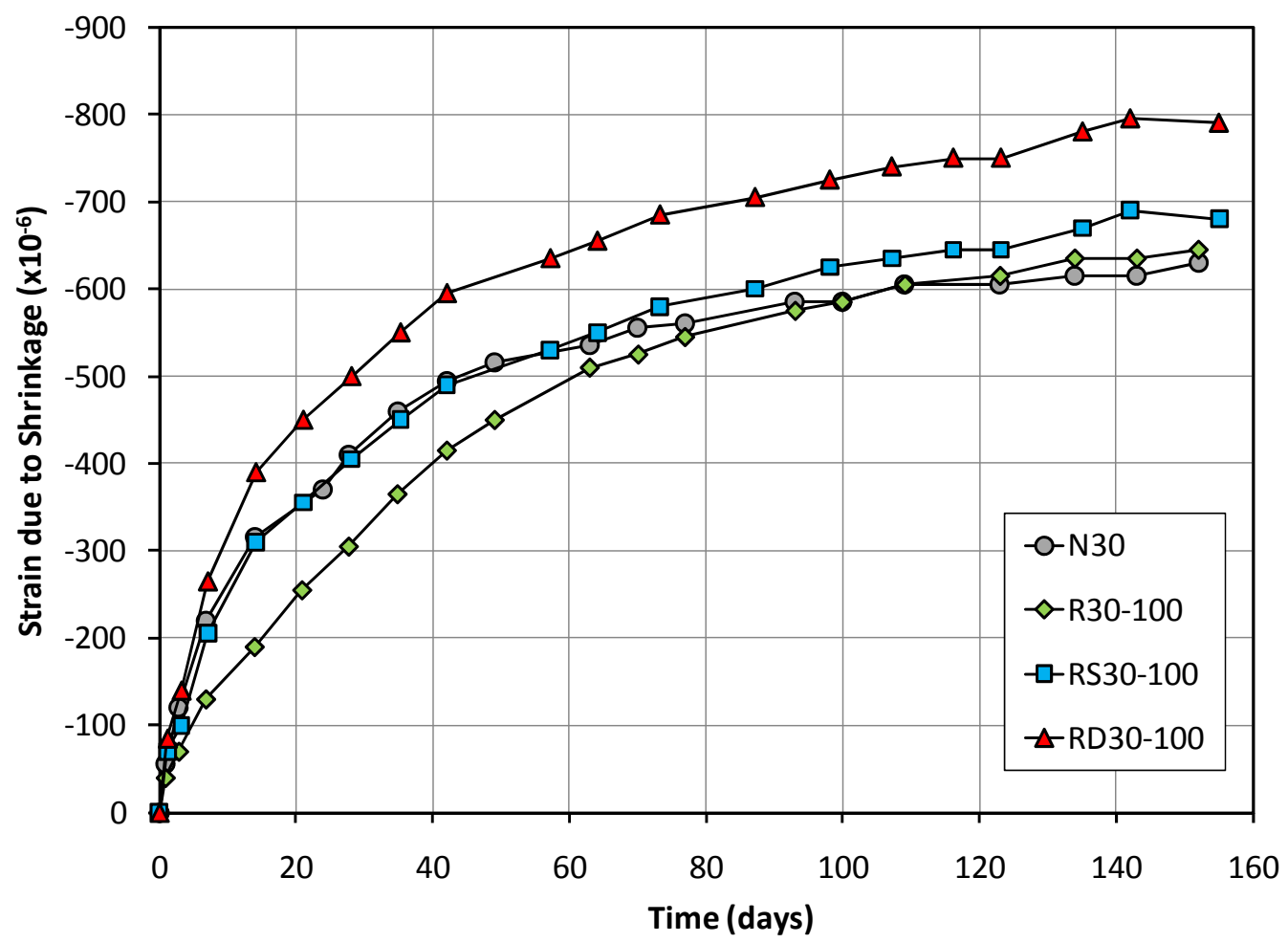

Figure 4-18: Drying Shrinkage Curves $(w / c=0.30)$

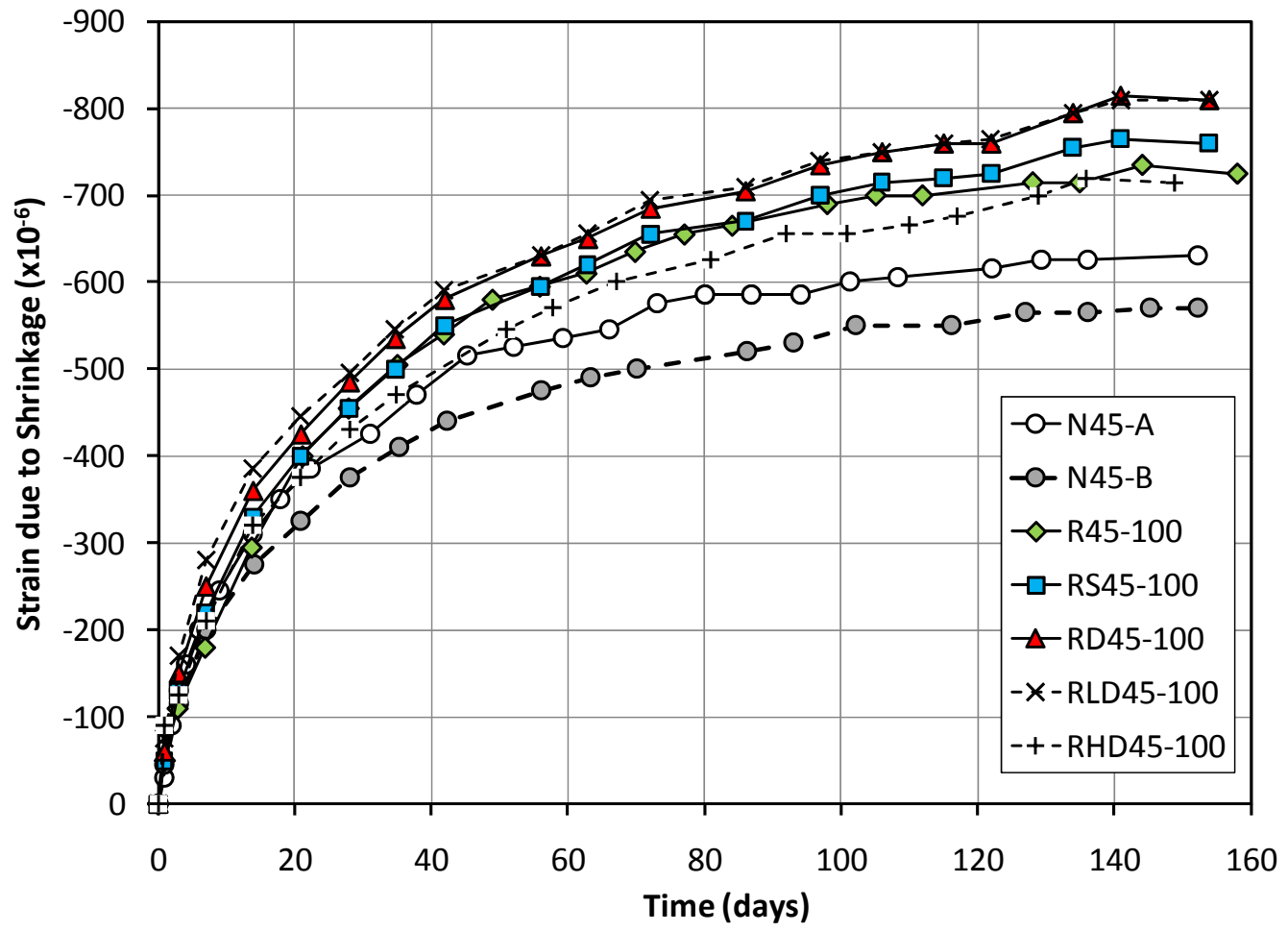

Figure 4-19: Drying Shrinkage Curves $(w / c=0.45)$ 


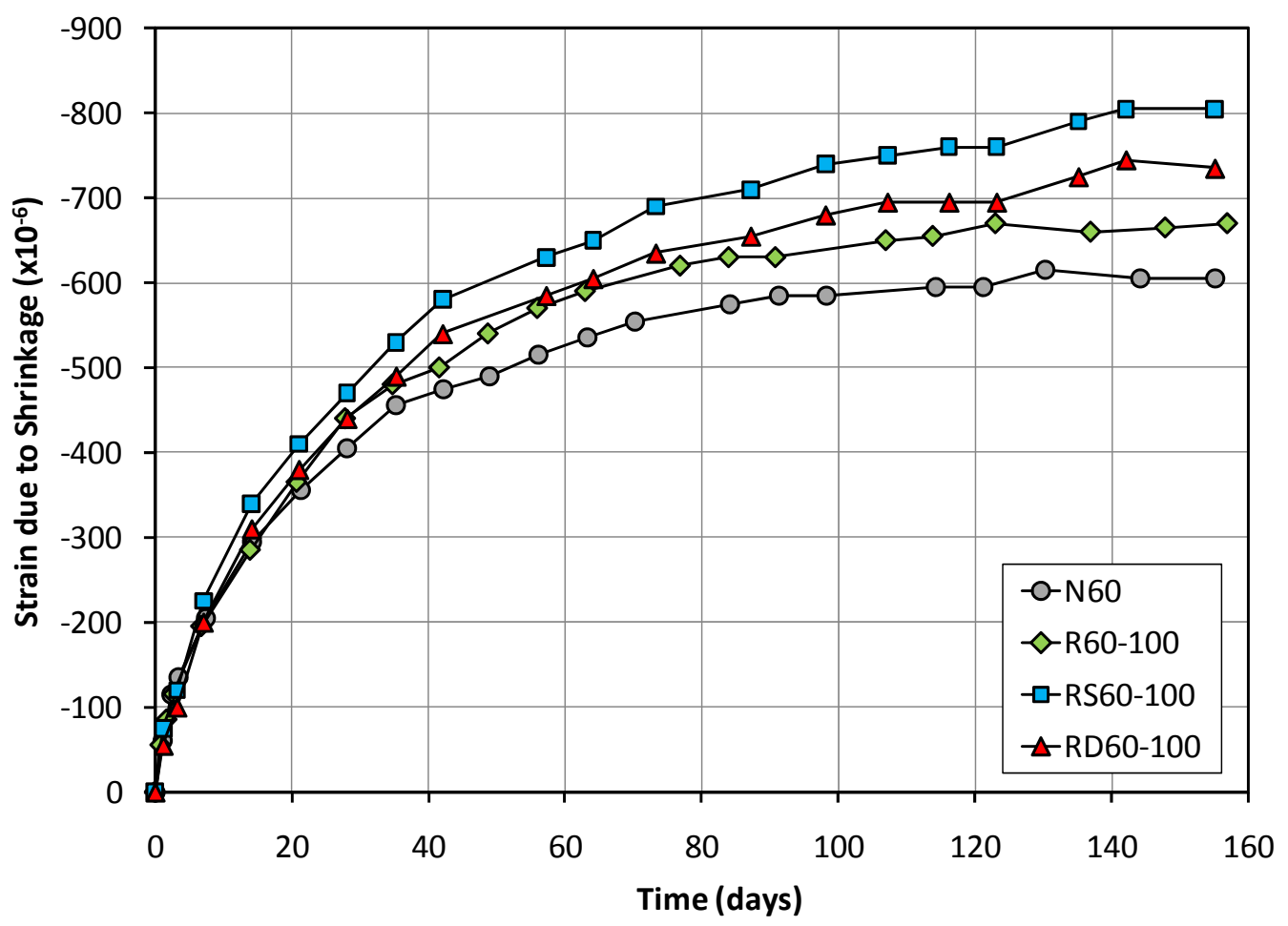

Figure 4-20: Drying Shrinkage Curves $(w / c=0.60)$

Control concretes in Figure 4-17 show similar shrinkage development. Neville ${ }^{27}$ states that at constant water content, shrinkage should be relatively unaffected despite changing w/c ratios. Figure 4-18 in particular shows a much slower shrinkage rate for RCA type R. The compressibility or stiffness of a coarse aggregate directly influences the modulus of elasticity and shrinkage of the concrete; therefore, mixes with stiffer coarse aggregates better retrain shrinkage ${ }^{6,26-28}$. Additional restraint is provided by the unhydrated cement grains and the stable micro-crystalline products of hydration ${ }^{60}$. RCA type $\mathrm{R}$ is a stiffer aggregate, which causes increased shrinkage resistance and a lower initial rate of shrinkage. Figure $4-19$ shows that for the $0.45 \mathrm{w} / \mathrm{c}$ concretes, the dried RCA provided the least resistance to shrinkage, followed by RCA types RS and R. Figure 4-20 indicates an opposite trend where RCA type RS concretes experienced more 
shrinkage than their dried RCA counterparts. Since RCA type RS was wet cured, it can be hypothesized that necessary hydration had been fulfilled. The $0.60 \mathrm{w} / \mathrm{c}$ ratio concretes contain more water to fulfill hydration demands of the old and new mortar compared to the lower w/c concrete mixes. Since no water was required for further hydration of RCA type RS, there was most likely excess water. This excess water is lost through drying shrinkage of the concrete $e^{6,26-28}$ and explains the larger shrinkage value associated with this RCA.

Self-desiccation by autogenous shrinkage can occur for very low w/c ratio concretes ( such as the case with $0.30 \mathrm{w} / \mathrm{c}$ ), and has been shown to contribute to a large portion of drying shrinkage for these low w/c ratio concretes ${ }^{6,26,27}$. However, since the shrinkage specimens were cured in a lime bath for 14 days, autogenous shrinkage was likely prevented. Figures 4-21 to 4-23 show the drying shrinkage curves for concrete batches with recycled aggregates type R, RS, and RD, respectively, for $100 \%$ replacement and at different w/c ratios. In Figure 4-21 and Figure 4-22, concretes with RCA type R and RS, respectively, show a trend of increased shrinkage with increased $\mathrm{w} / \mathrm{c}$ ratio, with the exception of the $0.45 \mathrm{w} / \mathrm{c}$ ratio concrete for RCA type $\mathrm{R}$. In general, decreasing the $\mathrm{w} / \mathrm{c}$ ratio can reduce shrinkage, as the mortar is better able to resist shrinkage ${ }^{27}$. Figure 4-23 depicts the opposite of this trend, but is likely due to the effects of the greater quantity of superplasticizer used for these dried RCA batches.

Additionally, reduced shrinkage can occur if cracking takes place around the aggregate particles $^{27}$, which would explain why the $0.60 \mathrm{w} / \mathrm{c}$ ratio concrete made with poorer quality RCA type RD showed less shrinkage than either 0.30 or $0.45 \mathrm{w} / \mathrm{c}$ concretes. Rates of shrinkage generally increased with increasing percent replacement of RCA. 


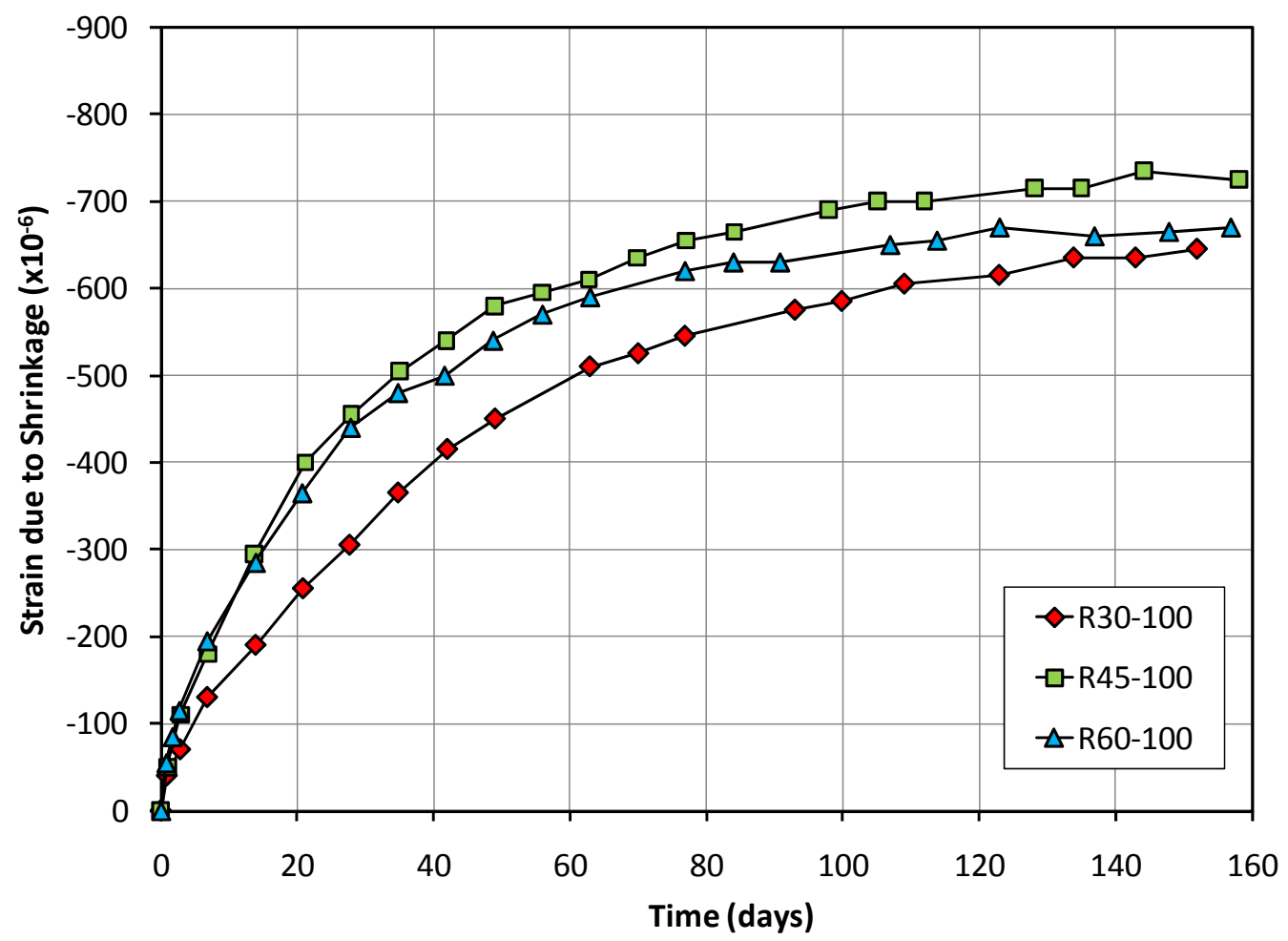

Figure 4-21: Drying Shrinkage Curves (100\% RCA type R)

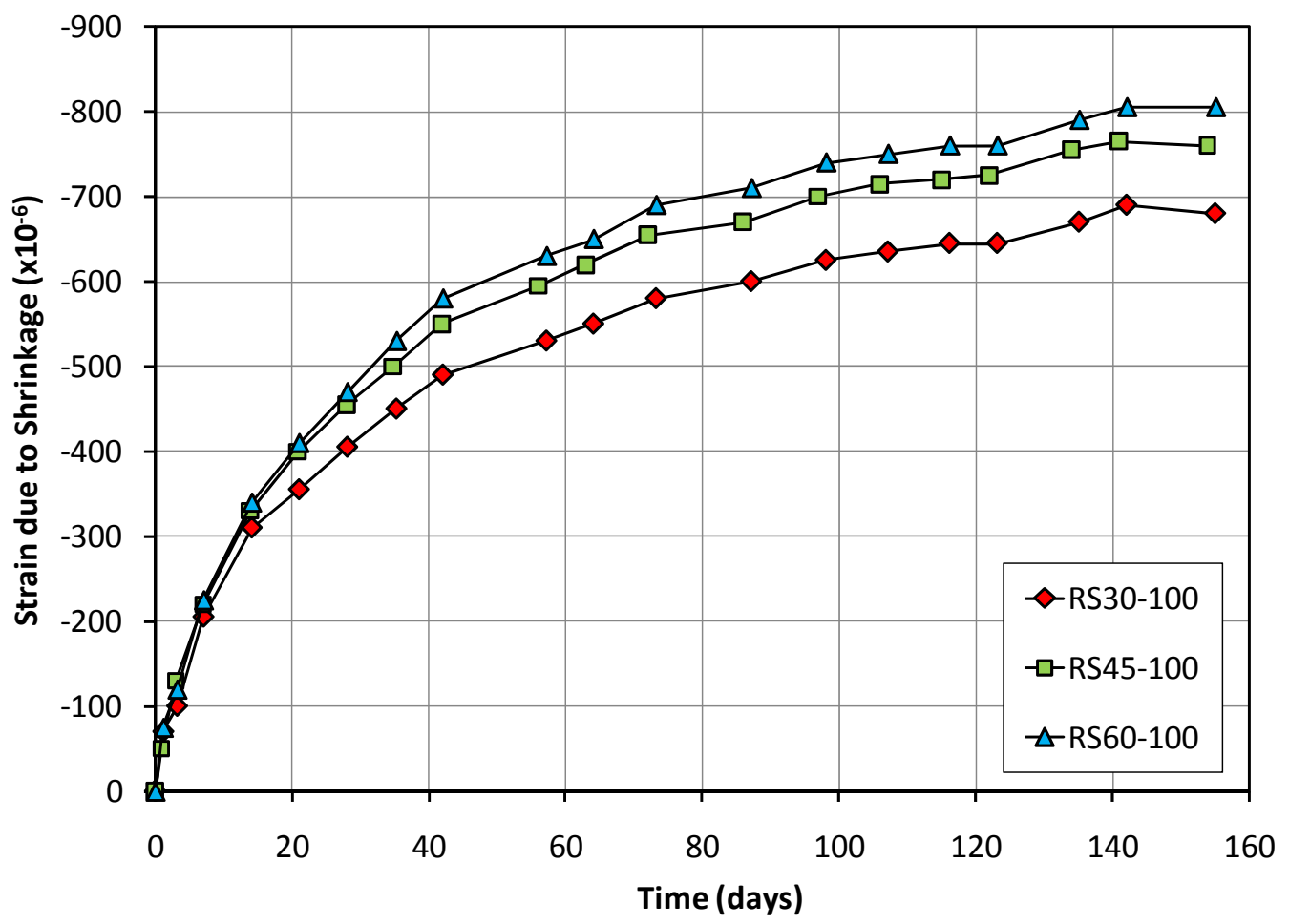

Figure 4-22: Drying Shrinkage Curves (100\% RCA type RS) 


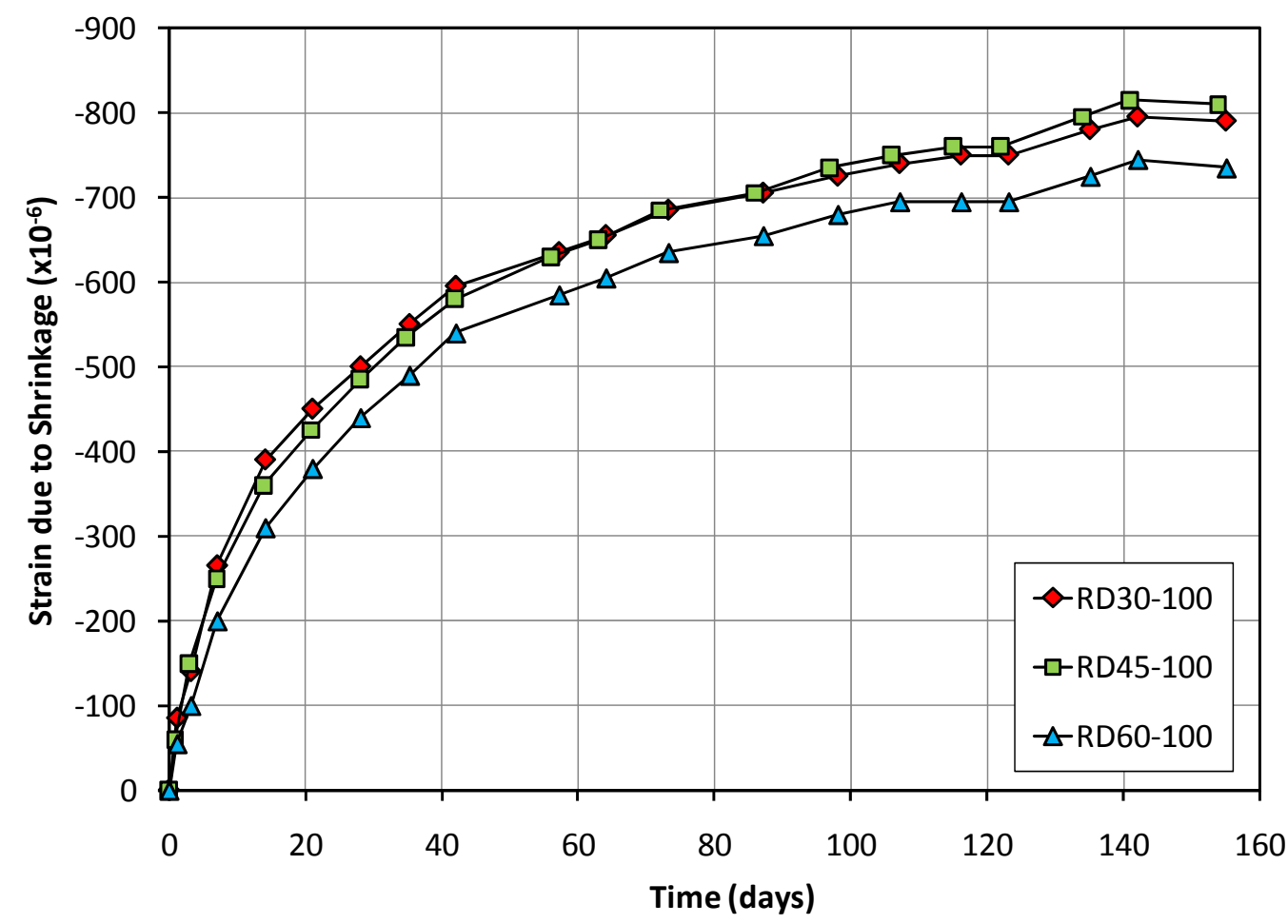

Figure 4-23: Drying Shrinkage Curves (100\% RCA type RD)

Previous research states that increasing levels of RCA in place of natural aggregate increases shrinkage in the concrete ${ }^{9,24,54,55}$. This trend is difficult to observe in concretes made with RCA type R for replacement percentages of 25 and $75 \%$. A possible explanation for this anomaly is the difference in RCA themselves. Since RCA type R comes from a commercial source, variation between bags of recycled aggregates may exist. Batches R45-25 and R45-75 were cast using aggregates from one bag of RCA, while batches R45-50 and R45-100 were cast with RCA from different bags. RCA produced in the laboratory showed the expected trend of increased shrinkage with increased percent replacement of RCA, as evident in Figure 4-25. 


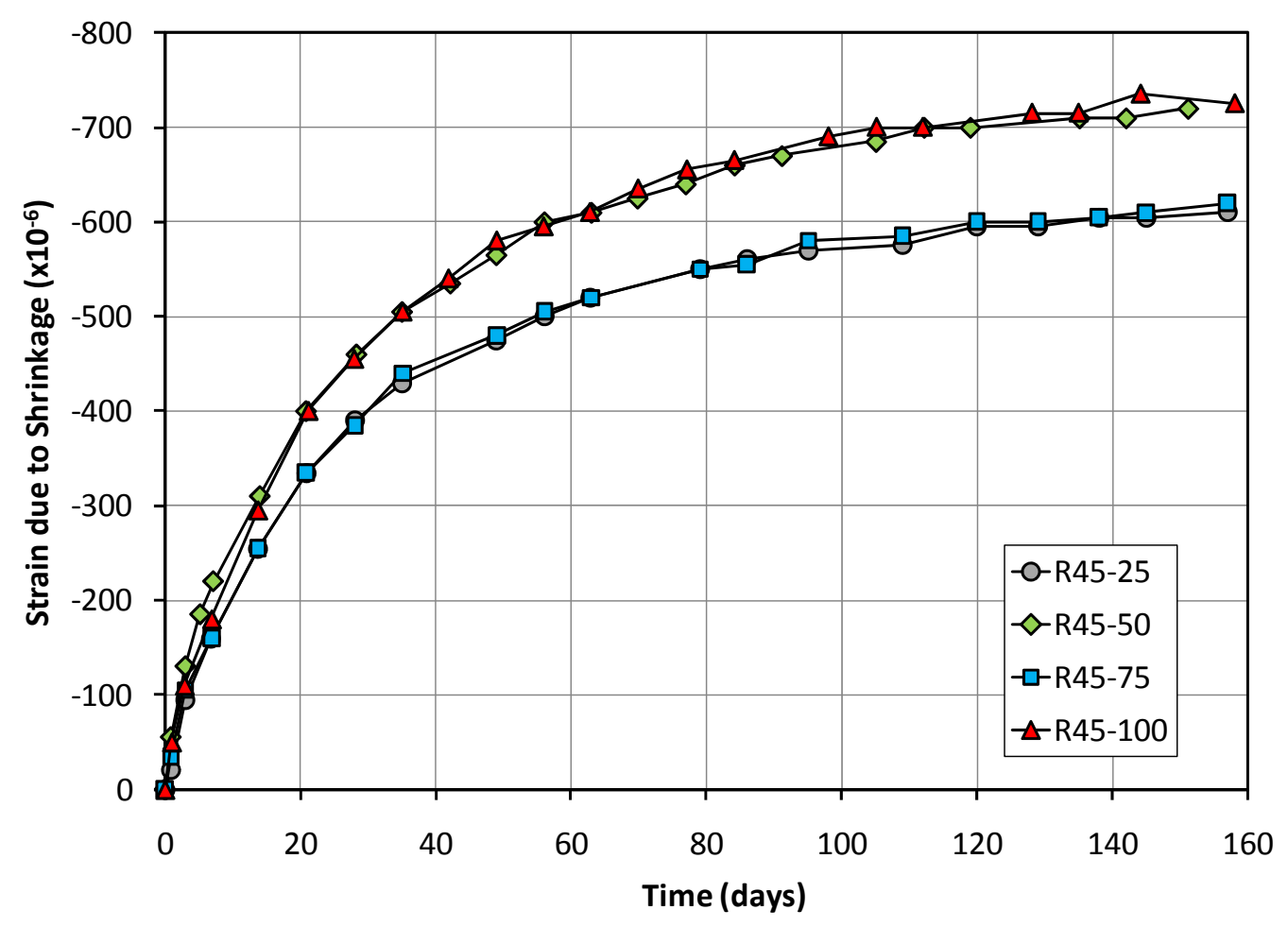

Figure 4-24: Drying Shrinkage Curves (25 - 100\% RCA type R)

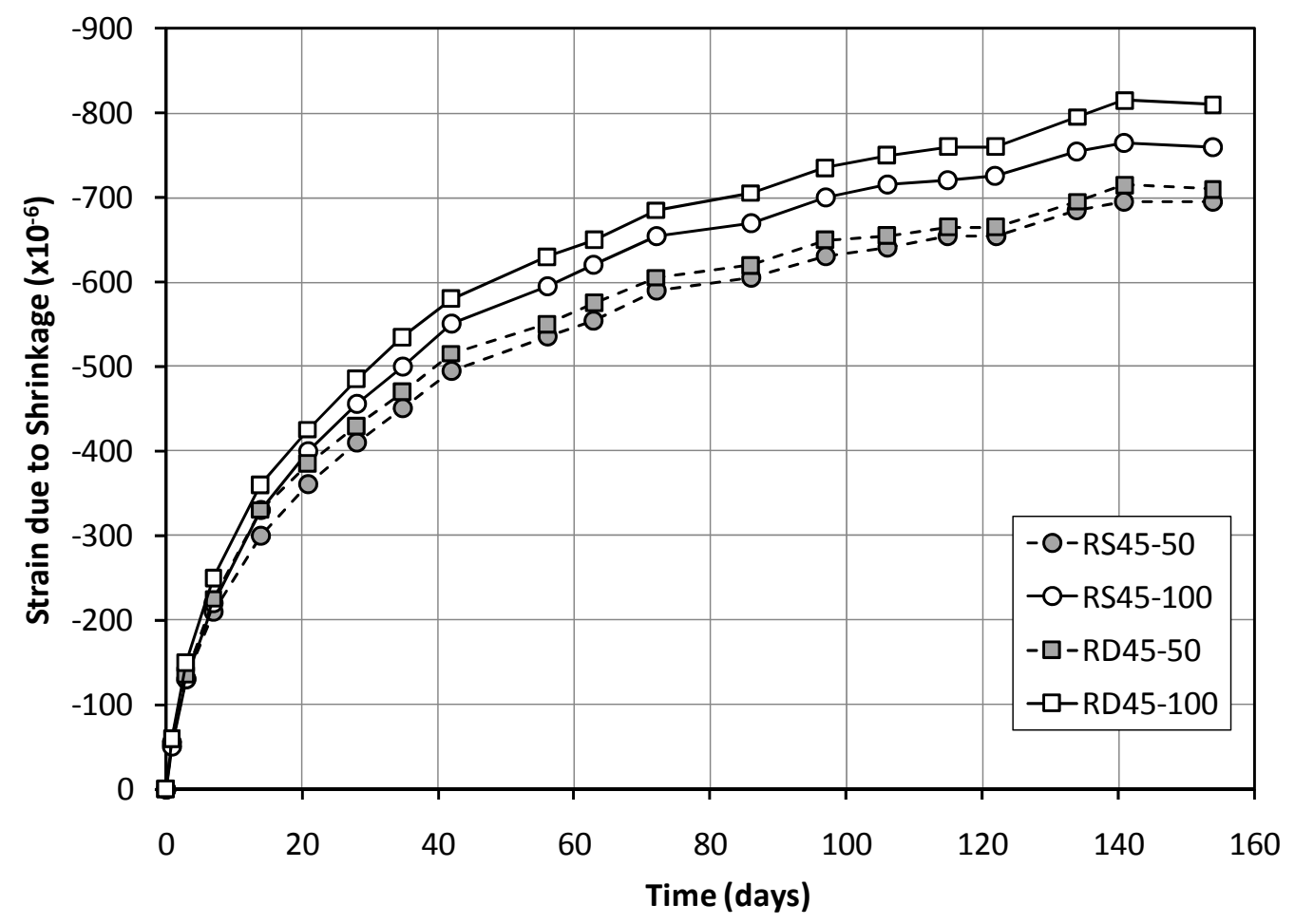

Figure 4-25: Drying Shrinkage Curves (50 \& 100\% RCA types RS \& RD) 
After shrinkage specimens had undergone approximately 150 days of drying, least squares analysis was used in conjunction with shrinkage models proposed by ACI209R$92^{57}$ and RILEM TC-107-GCS ${ }^{56}$ (Model B3). These models were modified to predict shrinkage values $\left(S_{t}\right.$ or $\left.\varepsilon_{s h}\right)$ corresponding to any set of data for time $t$ while changing the values of ultimate shrinkage $\left(S_{u l t}\right.$ or $\left.\varepsilon_{s h \infty}\right)$ and shrinkage halftime $\left(t_{0}\right.$ or $\left.\tau_{s h}\right)$. An example of this process is shown in Section 3.2. Appendix C-Shrinkage Curves, compares the predicted shrinkage curves from this statistical analysis to each specimen's shrinkage progression. It is apparent that both of these models perform adequately in predicting shrinkage strains. However, ACI 209R-92 appears to predict strains closer to the actual data than Model B3. Values for shrinkage half-time in Table 4-3 generally increase with increasing percent replacement of RCA. As mentioned previously, research shows that increasing percent replacement of natural aggregates with recycled aggregates increases shrinkage $e^{9,24,54,55}$. Greater shrinkages generally imply a longer shrinkage process, so it is expected that shrinkage half-time should be greater for increased levels of replacement with RCA in concrete. Additionally, increased values for shrinkage half-time imply slower rates of shrinkage (and vice-versa) to reach ultimate shrinkage. This trend is particularly evident when examining Figure 4-21, which shows the shrinkage curve for R45-100 to have a slow rate of shrinkage, and RD45-100 to have a fast rate of shrinkage. Shrinkage half-time values for concrete batches R45-100 and RD45-100 per ACI209R-92 are 44.2 and 19.1 days, respectively, thus confirming that a larger shrinkage half-time implies a slower rate of shrinkage. 
Ultimate shrinkage generally increases with increasing percent replacement of RCA. Figures 4-26 and 4-27 show this trend for RCA concrete with $0.45 \mathrm{w} / \mathrm{c}$ ratios, and previous studies for shrinkage with RAC support this finding $9,24,54,55$.

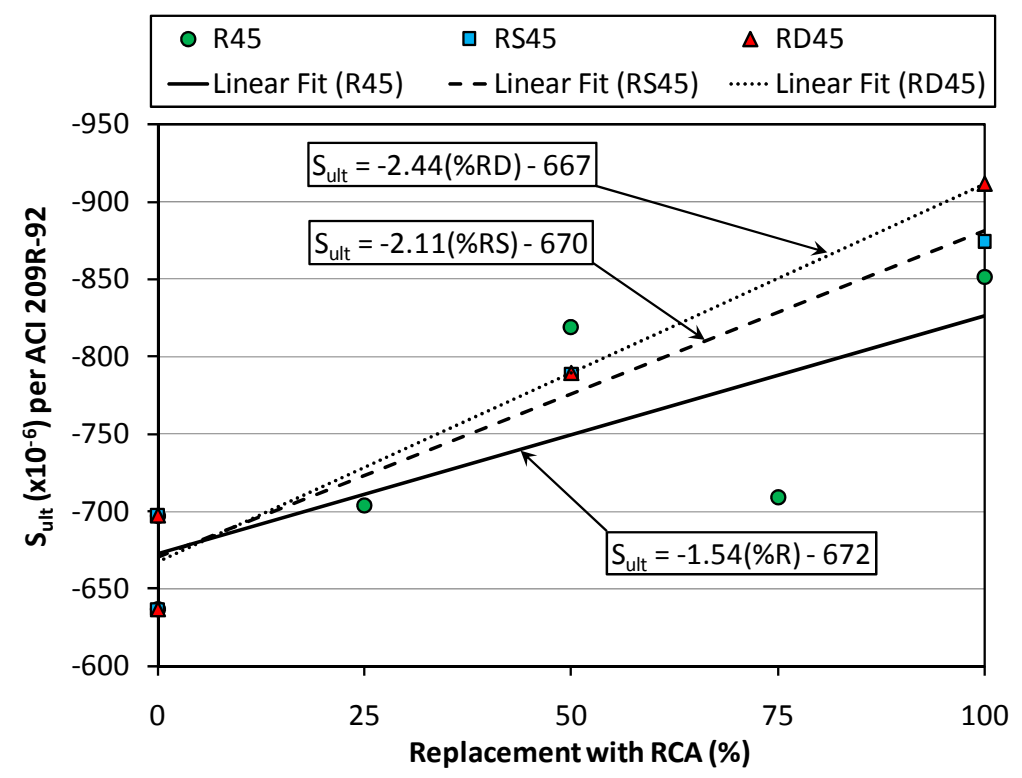

Figure 4-26: Ultimate Shrinkage as a Function of Increasing RCA Replacement Percentage $(\mathrm{w} / \mathrm{c}=0.45$, per ACI 209R-92)

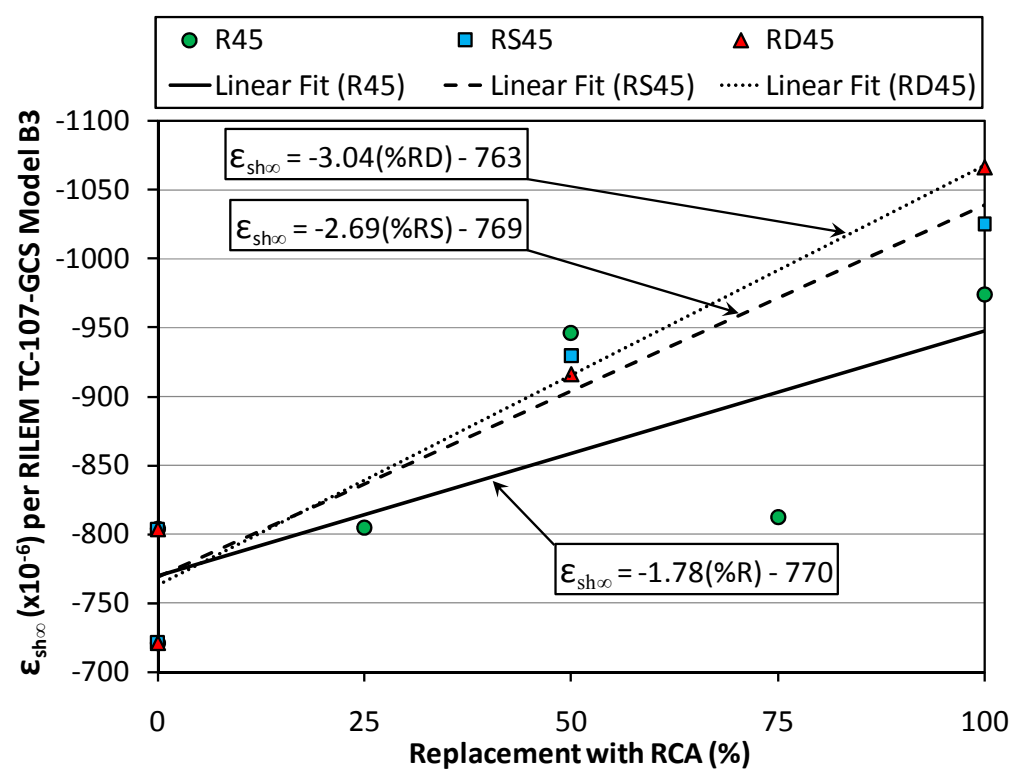

Figure 4-27: Ultimate Shrinkage as a Function of Increasing RCA Replacement Percentage $(w / c=0.45$, per RILEM TC-107-GCS Model B3) 
These figures also indicate that the quality of the RCA itself influences the value of ultimate shrinkage. The slope of the linear best-fit line indicates the relative resistance to shrinkage for that particular RCA; a smaller slope indicates less ultimate shrinkage. RCA type $\mathrm{R}$ has the smallest slope, followed by RCA type RS and RD. As previously discovered, RCA type R was the stiffer of the RCA, followed by RCA type RS and RD. Literature supports these findings, as coarse aggregates of higher quality (larger elastic modulus) will better restrain shrinkage of the mortar and the concrete specimen as a whole compared to concretes with low modulus of elasticity ${ }^{26-28}$. Model B3 also predicted larger values of half-time and ultimate shrinkage compared to those predicted by ACI209R-92. This difference could be due to simplification of Model B3.

Figures 4-28, 2-29, and 4-30 depict the relationship between ultimate shrinkage (predicted from ACI209R-92) and the compressive strength, the static modulus of elasticity, and the dynamic modulus of elasticity, respectively, for different $\mathrm{w} / \mathrm{c}$ ratio concretes. A linear best-fit line is included to better indicate any trends. These figures show that ultimate shrinkage decreases with increasing compressive strength, increasing $E_{c}$, and increasing $E_{d}$ regardless of the w/c ratio used. Ultimate shrinkage values are generally in agreement with trends reported in previous studies ${ }^{27,28}$, which state that shrinkage increases with increasing $\mathrm{w} / \mathrm{c}$ ratio, increases with increasing water content, and decreases with increasing cement content. Compared to control concretes, ultimate shrinkage values using RCA at $100 \%$ replacement were on average $10-35 \%$ higher. 


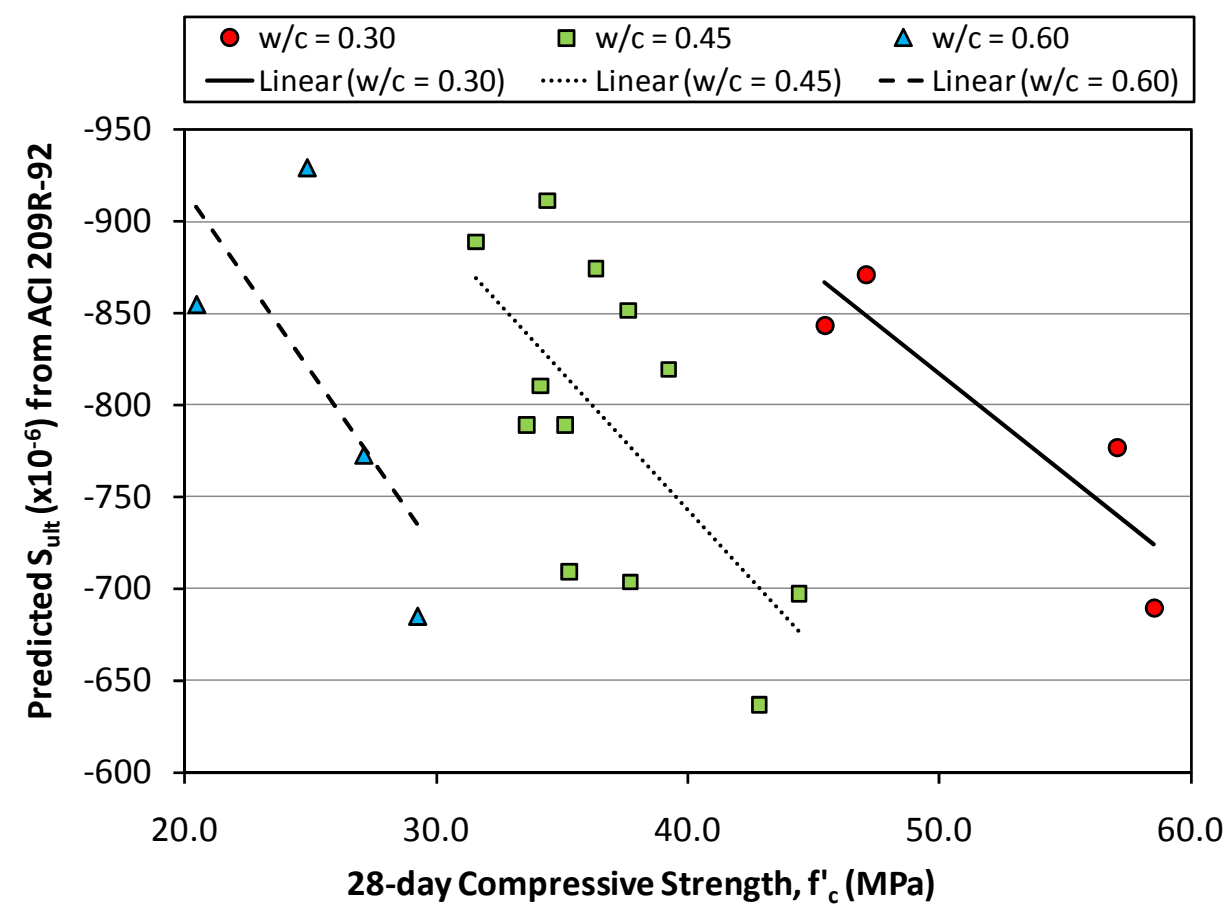

Figure 4-28: General Relationship between 28-day Compressive Strength and Ultimate Shrinkage (per ACI 209R-92); 1 MPa = 145.0 psi

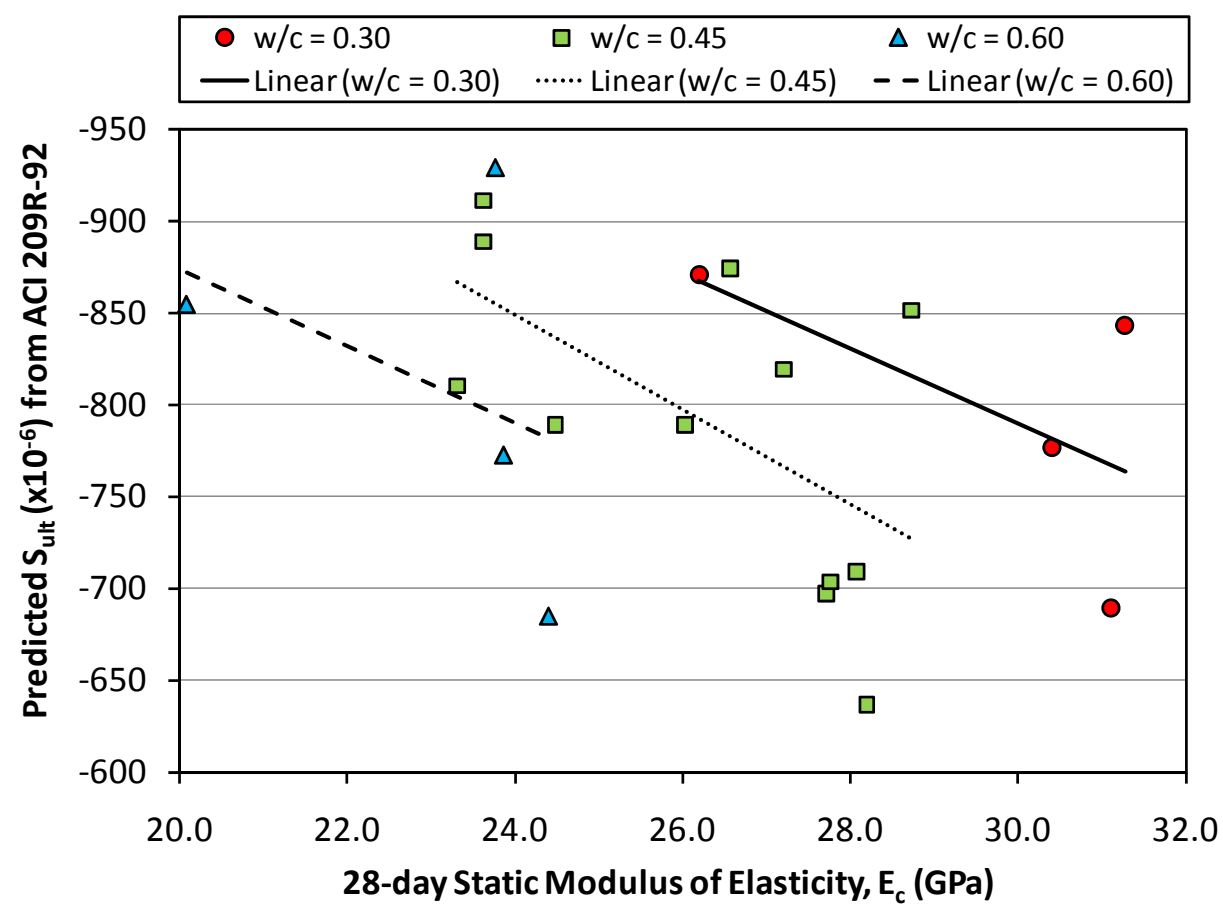

Figure 4-29: General Relationship between 28-day Static Modulus of Elasticity and Ultimate Shrinkage (per ACI 209R-92); 1 GPa $=145.0$ ksi 


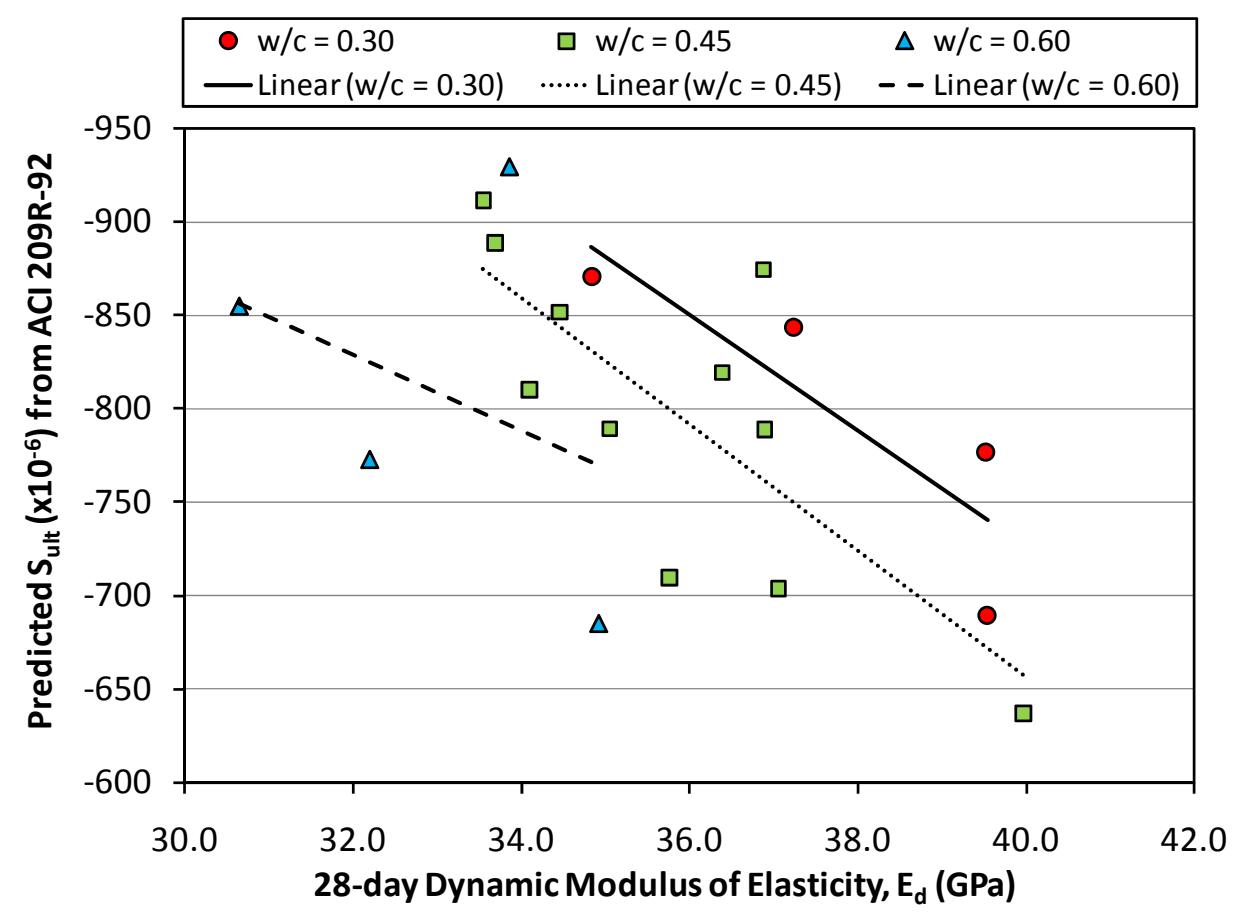

Figure 4-30: General Relationship between 28-day Dynamic Modulus of Elasticity and Ultimate Shrinkage (per ACI 209R-92); 1 GPa = 145.0 psi 


\section{Chapter 5 Conclusions}

Twenty different concrete batches prepared to different $\mathrm{w} / \mathrm{c}$ ratios were tested to examine how different types and replacement levels of RCA influence strength, modulus of elasticity, and shrinkage in concrete. This was accomplished by obtaining one type of RCA from a commercial source, and by preparing the other types of RCA within the laboratory. A climatic chamber was also constructed to store concrete specimens. Properties of the concrete specimens were tested according to all relevant ASTM standards, and results were compared to previous related literature. The following conclusions are drawn from this study:

1. Bulk specific gravity (BSG) and absorption for RCA was less than and greater than, respectively, that of natural coarse aggregate. BSG and absorption for RCA ranged from $2.43-2.47$ and $4.7-5.4 \%$, respectively. BSG and absorption for natural coarse aggregates was 2.61 and $1.4 \%$, respectively;

2. Workability decreases with decreasing $\mathrm{w} / \mathrm{c}$ ratios and increasing levels of replacement of natural aggregate with RCA. This increases the amount of superplasticizer required for lower w/c ratio concretes and higher levels of RCA replacement 
3. Compressive strength of RCA concrete decreases with increasing w/c ratio and generally decreases with increasing levels of RCA replacement. In this study, compressive strengths of the RCA concretes were on average $5-30 \%$ less than that of the control concretes. Additionally, compressive strengths at $100 \%$ replacement RCA were typically greater than those at 50\% replacement RCA. The individual qualities of the RCA determine its level of performance. RCA type RS performed the best for the $0.30 \mathrm{w} / \mathrm{c}$ concrete, as did RCA type $\mathrm{R}$ for the 0.45 and $0.60 \mathrm{w} / \mathrm{c}$ concretes;

4. Static $\left(E_{c}\right)$ and dynamic $\left(E_{d}\right)$ modulus of elasticity decrease with increasing w/c ratios and generally decrease with increasing levels of RCA replacement. $E_{c}$ and $E_{d}$ values were on average $0-20 \%$ and $5-15 \%$ less than that of their control concretes, respectively. As was the trend in compressive strength, $E_{c}$ and $E_{d}$ of RCA concretes are directly related to the individual properties of the RCA. This is confirmed using an elasticity model which examines concrete as a composite material. Using least squares analysis, normalized values were determined for elasticity of the mortar and the individual coarse aggregates. Values for the coarse aggregates and the mortar were normalized to the natural aggregate $(\mathrm{N})$ and to the $0.45 \mathrm{w} / \mathrm{c}$ concretes, respectively. The normalized values for the elasticity of the aggregates are 1.00, 1.04, 0.92, $0.63,0.66$, and 0.64 for RCA types N, R, RS, RD, RLD, and RHD, respectively. The normalized values for the elasticity of the mortar are $1.21,1.00$, and 0.81 for w/c ratios $0.30,0.45$, and 0.60 , respectively. RCA type R has the largest values for $E_{\mathrm{c}}$, while RCA type RS has the largest values for $E_{d}$. Age progression plots of $E_{d}$ show that the difference between $E_{d}$ values increases with age as greater percentages of natural aggregate are replaced with RCA. Additionally, the difference between $E_{d}$ 
values decreases with age for different w/c ratio concretes regardless of the type of coarse aggregate used. When different types of coarse aggregate are used but the w/c ratio of the concrete is kept constant, the difference between $E_{d}$ values with age stays relatively constant. $E_{c}$ and $E_{d}$ for recycled concretes can be modeled as a function of their compressive strength. These models for $E_{c}$ and $E_{d}$ of RAC yield values which are significantly lower $(20-30 \%)$ than typical values of $E_{c}$ and $E_{d}$ for natural aggregate concretes.

5. Strain due to drying shrinkage of RAC generally increases with increasing levels of RCA replacement. Rates and ultimate shrinkage strain are influenced by the individual properties of the aggregates. Least squares analysis was used in conjunction with shrinkage prediction models to better characterize these shrinkage rates and ultimate shrinkage values for RCA concretes. The rate of shrinkage is proportional to the shrinkage half-time value. Greater shrinkage half-time values indicate slower rates of shrinkage, like those seen in RCA type R, while smaller shrinkage half-time values indicate faster rates of shrinkage, like those seen in the dried recycled aggregates. Additionally, shrinkage rate is attributed to individual properties of the coarse aggregates. Stiffer coarse aggregates, such as types $\mathrm{N}$ and R, have slower rates of shrinkage compared to poorer quality dried aggregates. Additional analysis reveals that ultimate shrinkage decreases with increasing compressive strength, with increasing $E_{c}$, and with increasing $E_{d}$ regardless of the w/c ratio used. 
6. Further research using RAC with varying mortar content and additional levels of coarse aggregate replacement percentages would be beneficial in determining the precise elastic modulus properties of RCA concrete as a composite material.

Furthermore, RCA type RLD and RHD showed no significant difference from that of RCA type RD. Therefore, these aggregates should also be conditioned in the same manner as RCA type RS in order to better observe how different w/c ratio parent concretes will affect the properties of the new concrete when they are crushed and used as RCA. Crushing concrete with a jaw or impact crusher would allow laboratory-made concrete to age longer, thus promoting additional study on how age affects the properties of RCA and RAC. Additionally, use of constituent materials, such as fly ash, silica fume, or shrinkage reducing admixtures could provide additional insight into the use of RAC for higher quality applications. 


\section{References}

1. Nixon, P.J., "Recycled Concrete as an Aggregate for Concrete - A Review," First state-of-the-art report RILEM TC-37-DRC, Materials and Structures, No. 65, 1978, 371-378.

2. Hansen, T. C., "Recycled Aggregates and Recycled Aggregate Concrete Second State-Of-The-Art Report Developments 1945-1985," Materials and Structures, V. 19, No. 3, 1986, pp. 201-246.

3. Koulouris, A.; Limbachiya, M. C.; Fried, A. N.; and Roberts, J. J., "Use of Recycled Aggregate in Concrete Application: Case Studies," Kinston University, United Kingdom, 2004, pp. 245-257.

4. Marinković, S.; Radonjanin, V.; Malešev, M.; and Ignjatović, I., "Comparative Environmental Assessment of Natural and Recycled Aggregate Concrete," Waste Management, V. 30, No. 11, 2010, pp. 2255-2264.

5. Etxeberria, M.; Vázquez, E.; Marí, A.; and Barra, M., "Influence of Amount of Recycled Coarse Aggregates and Production Process on Properties of Recycled Aggregate Concrete," Cement and Concrete Research, V. 37, No. 5, 2007, pp. 735742.

6. Koshmatka, S. H.; Kerkhoff, B.; and Panarese, W. C., "Design and Control of Concrete Mixtures", 14th Edition, Portland Cement Association, Skokie, IL, 2002, $358 \mathrm{pp}$.

7. Hansen, T. C., and Boegh, E., "Elasticity and Drying Shrinkage of Recycled Concrete Aggregate," ACI Journal, Proceedings V. 82, No. 5, Sept.-Oct. 1985, pp. 648-652 
8. Sagoe-Crentsil, K., "Performance of Concrete Made With Commercially Produced Coarse Recycled Concrete Aggregate," Cement and Concrete Research, V. 31, No. 5, 2001, pp. 707-712.

9. Domingo-Cabo, A.; Lázaro, C.; López-Gayarre, F.; Serrano-López, M. A,; Serna, P.; and Castaño-Tabares, J. O., "Creep and Shrinkage of Recycled Aggregate Concrete," Construction and Building Materials, V. 23, No. 7, 2009, pp. 2545-2553.

10. Tabsh, S., and Abdelfatah, A., "Influence of Recycled Concrete Aggregates on Strength Properties of Concrete," Construction and Building Materials, V. 23, No. 2, 2009, pp. 1163-1167.

11. Nishibayashi, S.; Yamura, K.; and Hayashi, A., "Elastic-Plastic Properties of Concrete Made From Recycled Coarse Aggregate Prepared by Crushing Concrete," Japan Concrete Institute, V. 6, 1984, pp. 127-132.

12. Topcu, L., "Properties of Concretes Produced with Waste Concrete Aggregate," Cement and Concrete Research, V. 34, No. 8, 2004, pp. 1307-1312.

13. Rakshvir, M., "Studies on Recycled Aggregates-Based Concrete," Waste Management \& Research, V. 24, No. 3, 2006, pp. 225-233.

14. Xiao, J.; Li, J.; and Zhang, C., "Mechanical Properties of Recycled Aggregate Concrete Under Uniaxial Loading," Cement and Concrete Research, V. 35, No. 6, 2005, pp. 1187-1194.

15. Tam, V.; Tam, C.; and Wang, Y., "Optimization on Proportion for Recycled Aggregate In Concrete Using Two-Stage Mixing Approach," Construction and Building Materials, V. 21, No. 10, 2007, pp. 1928-1939.

16. Limbachiya, M. C.; Leelawat, T.; and Dhir, R. K., "Use ff Recycled Concrete Aggregate in High-Strength Concrete," Materials and Structures, V. 33, No. 9, 2000, pp. 574-580.

17. Etxeberria, M.; Marí, A. R.; and Vázquez, E., "Recycled Aggregate Concrete as Structural Material," Materials and Structures, V. 40, No. 5, 2007, pp. 529-541.

18. Zhang, W., and Ingham, J. M., "Using Recycled Concrete Aggregates in New Zealand Ready-Mix Concrete Production," Journal of Materials in Civil Engineering, V. 22, No. 5, 2010, pp. 22(5), 443-450.

19. Shayan, A., and $\mathrm{Xu}, \mathrm{A} .$, "Performance and Properties of Structural Concrete Made with Recycled Concrete Aggregate," ACI Materials Journal, V. 100, No. 5, 2002, pp. 371-380. 
20. Padmini, A.; Ramamurthy, K.; and Mathews, M., "Influence of Parent Concrete on the Properties of Recycled Aggregate Concrete," Construction and Building Materials, V. 23, No. 2, 2009, pp. 829-836.

21. Dejuan, M., and Gutierrez, P., "Study on the influence of attached mortar content on the properties of recycled concrete aggregate," Construction and Building Materials, V. 23, 2009, pp. 872-877.

22. Ravindrarajah, R. S., and Tam, C. T., "Properties of Concrete made with Crushed Concrete as Coarse Aggregate," Magazine of Concrete Research, V. 37, No. 130, 1985, pp. 29-38.

23. Rao, M. C.; Bhattacharyya, S. K.; and Barai, S. V., "Influence of Field Recycled Coarse Aggregate on Properties of Concrete," Materials and Structures, V. 44, No. 1, 2011, pp. 205-220.

24. Yang, K.-H.; Chung, H.-S.; and Ashout, A. F., "Influence of Type and Replacement Level of Recycled Aggregates on Concrete Properties," ACI Materials Journal, V. 105, No. 3, 2008, pp. 289-296.

25. Ajdukiewicz, A., and Kliszczewicz, A., "Influence of Recycled Aggregates on Mechanical Properties of HS/HPC," Cement and Concrete Composites, V. 36, No. 2, 2002, pp. 269-279.

26. Mindess, S.; Young, J. F.; and Darwin, D. "Concrete," 2nd Edition, Pearson Education, Inc., Upper Saddle River, NJ, 2003, 644 pp.

27. Neville, A. M., "Properties of Concrete," 4th Edition, John Wiley \& Sons Publisher, New York, NY, 1996, 844 pp.

28. ACI Committee 209, "Report on Factors Affecting Shrinkage and Creep of Hardened Concrete (ACI 209.1R-05)," American Concrete Institute, Farmington Hills, MI, 2005, 12 pp.

29. ASTM C127-07, "Standard Test Method for Density, Relative Density (Specific Gravity), and Absorption of Coarse Aggregate," American Society for Testing and Material, 2007.

30. ASTM C128-07, "Standard Test Method for Density, Relative Density (Specific Gravity), and Absorption of Fine Aggregate," American Society for Testing and Material, 2007.

31. ASTM C136-06, "Standard Test Method for Sieve Analysis of Fine and Coarse Aggregates," American Society for Testing and Material, 2006. 
32. Katz, A., "Properties of Concrete Made with Recycled Aggregate from Partially Hydrated Old Concrete," Cement and Concrete Research, V. 33, No. 5, 2003, pp. 703-711.

33. Poon, C., "Influence of Moisture States of Natural and Recycled Aggregates on the Slump and Compressive Strength of Concrete," Cement and Concrete Research, V. 34, No. 1, 2004, pp. 31-36.

34. ASTM C33-11, "Standard Specifications for Concrete Aggregates," American Society for Testing and Material, 2011.

35. Khatib, J., "Properties of Concrete Incorporating Fine Recycled Aggregate," Cement and Concrete Research, V. 35, No. 4, 2005, pp. 763-769.

36. Rahal, K., "Mechanical Properties of Concrete with Recycled Coarse Aggregate," Building and Environment, V. 42, No. 1, 2007, pp. 407-415.

37. Brooks, J. J., "Influence of Mix Proportions, Plasticizers and Superplasticizers on Creep and Drying Shrinkage of Concrete," Magazine of Concrete Research, V. 41, No. 148, 1989, pp. 145-153.

38. Brooks, J. J., "How Admixtures Affect Shrinkage and Creep," Concrete International, V. 21, No. 4, 1999, pp. 35-38.

39. ASTM C192-07, "Standard Test Method for Making and Curing Concrete Test Specimens in the Laboratory," American Society for Testing and Material, 2007.

40. ASTM C138-10, "Standard Test Method for Density (Unit Weight), Yield, and Air Content (Gravimetric) of Concrete," American Society for Testing and Material, 2010.

41. ASTM C39-10, "Standard Test Method for Compressive Strength of Cylindrical Concrete Specimens,” American Society for Testing and Material, 2010.

42. ASTM C469-10, "Standard Test Method for Static Modulus of Elasticity and Poisson's Ratio of Concrete in Compression," American Society for Testing and Material, 2010.

43. ASTM C215-08, "Standard Test Method for Fundamental Transverse, Longitudinal, and Torsional Resonant Frequencies of Concrete Specimens," American Society for Testing and Material, 2008.

44. ASTM C157-08, "Standard Test Method for Length Change of Hardened HydraulicCement Mortar and Concrete," American Society for Testing and Material, 2008. 
45. ASTM 490-10, "Standard Practice for Use of Apparatus for the Determination of Length Change of Hardened Cement Paste, Mortar, and Concrete," American Society for Testing and Material, 2010.

46. ASTM C511-09, "Standard Specification for Mixing Rooms, Moist Cabinets, Moist Rooms, and Water Storage Tanks Used in the Testing of Hydraulic Cements and Concretes," American Society for Testing and Material, 2009.

47. Frondistou-Yannis, S., "Waste Concrete as Aggregate for New Concrete," ACI Journal, Proceedings V. 74, No. 8, Aug. 1977, pp. 373-376.

48. Etxeberria, M.; Vázquez, E.; and Marí, A., "Microstructure Analysis of Hardened Recycled Aggregate Concrete," Magazine of Concrete Research, V. 58, No. 10, 2006, pp. 683-690

49. NIST/SEMATECH, "e-Handbook of Statistical Methods," http://www.itl.nist.gov/div898/handbook/pmd/section1/pmd142.htm, 2011.

50. Merriman, M., “American Civil Engineers' Pocket Book," 3rd Edition, John Wiley \& Sons, Inc., University of Wisconsin - Madison, 1916, $1591 \mathrm{pp}$.

51. Hirsch, T. J., "Modulus of Elasticity of Concrete Affected by Elastic Moduli of Cement Paste Matrix and Aggregate," ACI Journal, Proceedings V. 59, No. 12, March 1962, pp. 427-451.

52. ACI Committee 318, "Building Code Requirements for Structural Concrete (ACI 318-08) and Commentary (318R-08)," American Concrete Institute, Farmington Hills, MI, 2008, 456 pp.

53. Tavakoli, M., and Soroushian, P., "Drying Shrinkage Behavior of Recycled Aggregate Concrete," Concrete International, V. 18, No. 11, 1996, pp. 58-61.

54. Eguchi, K.; Teranishi, K.; Nakagome, A.; Kishimoto, H.; Shinozaki, K.; and Narikawa, M., "Application of Recycled Coarse Aggregate by Mixture to Concrete Construction," Construction and Building Materials, V. 21, No. 7, 2007, pp. 15421551.

55. Cabral, A. E. B.; Schalch, V.; and Molin, D., "Shrinkage Modeling for Recycled Aggregate Concretes," Structures and Materials, V. 3, No. 1, 2010, pp. 1-11.

56. RILEM TC-107-GCS, "Creep and Shrinkage Prediction Model for Analysis and Design of Concrete Structures - Model B3," Materials and Structures, V. 28, 1995 , pp. 357-365. 
57. ACI Committee 209, "Prediction of Creep, Shrinkage and Temperature Effect in Concrete Structures (ACI 209R-92)," American Concrete Institute, Farmington Hills, MI, 1992, 47 pp.

58. Gao, X., "Investigation of Micro-Cracks and Microstructure of High Performance Lightweight Aggregate Concrete," Building and Environment, V. 37, No. 5, 2002, pp. 485-489.

59. Watstein, D., "Effect of Straining Rate on the Compressive Strength and Elastic Properties of Concrete," ACI Journal, Proceedings V. 49, No. 4, Apr. 1953, pp. 729744.

60. Pickett, G., "Effect of Aggregate on Shrinkage on Concrete and a Hypothesis Concerning Shrinkage," ACI Journal, Proceedings V. 52, No. 36, Jan. 1956, pp. 581590. 


\section{Appendix A Batch Records}


Table A-1: Batch Record for N45-A

Mix Designation: N45-A

Date Cast: $\quad 6 / 22 / 2010$

Time Cast: $\quad 12: 30$

\begin{tabular}{|c|c|c|c|c|c|c|c|c|}
\hline & \multirow{2}{*}{\multicolumn{4}{|c|}{ Mixture Proportions }} \\
\hline & & & & & & & & \\
\hline Material & Description & $\begin{array}{l}\text { Specific } \\
\text { Gravity }\end{array}$ & Absorption & $\begin{array}{c}\text { Moisture } \\
\text { Content }\end{array}$ & $\begin{array}{c}\text { Stock WTS } \\
\text { (lbs/batch) }\end{array}$ & $\begin{array}{c}\text { Stock WTS } \\
\left(\mathrm{lbs} / \mathrm{yd}^{3}\right)\end{array}$ & $\begin{array}{c}\text { SSD WTS } \\
\left(1 \mathrm{bs} / \mathrm{yd}^{3}\right)\end{array}$ & $\begin{array}{c}\text { ABS Volume } \\
\left(\mathrm{ft}^{3} / \mathrm{yd}^{3}\right)\end{array}$ \\
\hline Cement & Portland Type II/V & 3.15 & N/A & N/A & 80.0 & 717 & 717 & 3.647 \\
\hline Water & Municipal Water & 1.00 & $\mathrm{~N} / \mathrm{A}$ & $\mathrm{N} / \mathrm{A}$ & 32.9 & 295 & 323 & 5.175 \\
\hline Coarse Aggregates & Santa Margarita 1 "x\#4 & 2.61 & $1.4 \%$ & $0.3 \%$ & 179.2 & 1606 & 1623 & 9.966 \\
\hline Recycled Concrete & N/A & 2.47 & $4.9 \%$ & $0.0 \%$ & 0.0 & 0 & 0 & 0.000 \\
\hline Fine Aggregates & Sisquoc C33 Sand & 2.56 & $2.2 \%$ & $6.0 \%$ & 142.3 & 1275 & 1230 & 7.699 \\
\hline \multicolumn{2}{|c|}{ Air Content, Non-air-entrained (Entrapped) } & $\mathrm{N} / \mathrm{A}$ & $\mathrm{N} / \mathrm{A}$ & $\mathrm{N} / \mathrm{A}$ & $\mathrm{N} / \mathrm{A}$ & $\mathrm{N} / \mathrm{A}$ & $\mathrm{N} / \mathrm{A}$ & 0.513 \\
\hline Total & & & & & 434 & 3893 & 3893 & 27.000 \\
\hline Superplasticizer & W.R. Grace ADVA 100 & & & & 70 & $\mathrm{ml} / \mathrm{batch}$ & 21.2 & $\mathrm{oz} / \mathrm{yd}^{3}$ \\
\hline
\end{tabular}

Temperature $\left({ }^{\circ} \mathrm{F}\right): \quad 70.0$

Slump (inches): $\quad 6.500$

Unit Weight $\left(\mathrm{lbs} / \mathrm{ft}^{3}\right): \quad 144.2$

Air Content, Pressure Method (\%): N/A

Air Content, Volumetric Method (\%): $\quad 1.9 \%$

Batch Size $\left(\mathrm{ft}^{3}\right): \quad 3.013$

\begin{tabular}{|c|c|c|c|}
\hline \multicolumn{4}{|c|}{ Moisture Contents } \\
\hline & Sant. Marg. & N/A & Sand \\
\hline Pan (g.) & 639 & 0 & 633 \\
\hline Pan+Stock (g.) & 4352 & 1 & 3688 \\
\hline Pan+OD (g.) & 4340 & 1 & 3516 \\
\hline M.C. (\%) & $0.3 \%$ & $0.0 \%$ & $6.0 \%$ \\
\hline
\end{tabular}


Table A-2: Batch Record for N45-B

Mix Designation: N45-B

Date Cast: $\quad 8 / 27 / 2010$

Time Cast: $\quad$ 11:30

\begin{tabular}{|c|c|c|c|c|c|c|c|c|}
\hline & & & & & \multirow{2}{*}{\multicolumn{4}{|c|}{ Mixture Proportions }} \\
\hline & & & & & & & & \\
\hline Material & Description & $\begin{array}{c}\text { Specific } \\
\text { Gravity } \\
\end{array}$ & Absorption & $\begin{array}{c}\text { Moisture } \\
\text { Content } \\
\end{array}$ & $\begin{array}{c}\text { Stock WTS } \\
\text { (lbs/batch) } \\
\end{array}$ & $\begin{array}{c}\text { Stock WTS } \\
\left(\mathrm{lbs} / \mathrm{yd}^{3}\right) \\
\end{array}$ & $\begin{array}{c}\text { SSD WTS } \\
\left(\mathrm{lbs} / \mathrm{yd}^{3}\right) \\
\end{array}$ & $\begin{array}{c}\text { ABS Volume } \\
\left(\mathrm{ft}^{3} / \mathrm{yd}^{3}\right) \\
\end{array}$ \\
\hline Cement & Portland Type II/V & 3.15 & $\mathrm{~N} / \mathrm{A}$ & $\mathrm{N} / \mathrm{A}$ & 36.0 & 721 & 721 & 3.670 \\
\hline Water & Municipal Water & 1.00 & N/A & N/A & 16.1 & 323 & 325 & 5.214 \\
\hline Coarse Aggregates & Santa Margarita 1"x\#4 & 2.61 & $1.4 \%$ & $0.3 \%$ & 80.6 & 1615 & 1633 & 10.026 \\
\hline Recycled Concrete & $\mathrm{N} / \mathrm{A}$ & 2.47 & $4.9 \%$ & $0.0 \%$ & 0.0 & 0 & 0 & 0.000 \\
\hline Fine Aggregates & Sisquoc C33 Sand & 2.56 & $2.2 \%$ & $3.9 \%$ & 62.8 & 1258 & 1238 & 7.750 \\
\hline \multicolumn{2}{|c|}{ Air Content, Non-air-entrained (Entrapped) } & $\mathrm{N} / \mathrm{A}$ & $\mathrm{N} / \mathrm{A}$ & $\mathrm{N} / \mathrm{A}$ & $\mathrm{N} / \mathrm{A}$ & $\mathrm{N} / \mathrm{A}$ & N/A & 0.340 \\
\hline Total & & & & & 196 & 3918 & 3918 & 27.000 \\
\hline Superplasticizer & W.R. Grace ADVA 100 & & & & 30 & $\mathrm{ml} / \mathrm{batch}$ & 20.3 & $\mathrm{oz} / \mathrm{yd}^{3}$ \\
\hline
\end{tabular}

Temperature $\left({ }^{\circ} \mathrm{F}\right): \quad 72.0$

Slump (inches): $\quad 7.000$

Unit Weight $\left(\mathrm{lbs} / \mathrm{ft}^{3}\right): \quad 145.1$

Air Content, Pressure Method (\%): N/A

Air Content, Volumetric Method (\%): $\quad 1.3 \%$

Batch Size $\left(\mathrm{ft}^{3}\right): \quad 1.347$

\begin{tabular}{|c|c|c|c|}
\hline \multicolumn{4}{|c|}{ Moisture Contents } \\
\hline & Sant. Marg. & N/A & Sand \\
\hline Pan (g.) & 634.8 & 0 & 635 \\
\hline Pan+Stock (g.) & 3968.1 & 1 & 4274.1 \\
\hline Pan+OD (g.) & 3958.2 & 1 & 4137.9 \\
\hline M.C. (\%) & $0.3 \%$ & $0.0 \%$ & $3.9 \%$ \\
\hline
\end{tabular}


Table A-3: Batch Record for R45-25

Mix Designation: R45-25

Date Cast: $\quad$ 9/3/2010

Time Cast: $\quad 12: 30$

\begin{tabular}{|c|c|c|c|c|c|c|c|c|}
\hline & \multirow{2}{*}{\multicolumn{4}{|c|}{ "Mixture Proportions }} \\
\hline & & & & & & & & \\
\hline Material & Description & $\begin{array}{l}\text { Specific } \\
\text { Gravity } \\
\end{array}$ & Absorption & $\begin{array}{c}\text { Moisture } \\
\text { Content } \\
\end{array}$ & $\begin{array}{c}\text { Stock WTS } \\
\text { (lbs/batch) }\end{array}$ & $\begin{array}{c}\text { Stock WTS } \\
\left(\mathrm{lbs} / \mathrm{yd}^{3}\right) \\
\end{array}$ & $\begin{array}{c}\text { SSD WTS } \\
\left(\mathrm{lbs} / \mathrm{yd}^{3}\right)\end{array}$ & $\begin{array}{c}\text { ABS Volume } \\
\left(\mathrm{ft}^{3} / \mathrm{yd}^{3}\right)\end{array}$ \\
\hline Cement & Portland Type II/V & 3.15 & N/A & N/A & 36.0 & 723 & 723 & 3.681 \\
\hline Water & Municipal Water & 1.00 & N/A & N/A & 16.0 & 322 & 326 & 5.221 \\
\hline Coarse Aggregates & Santa Margarita 1"x\#4 & 2.61 & $1.4 \%$ & $0.3 \%$ & 60.5 & 1216 & 1229 & 7.547 \\
\hline Recycled Concrete & $\mathrm{R}$ & 2.47 & $4.9 \%$ & $1.6 \%$ & 18.7 & 376 & 388 & 2.518 \\
\hline Fine Aggregates & Sisquoc C33 Sand & 2.56 & $2.2 \%$ & $4.7 \%$ & 63.2 & 1270 & 1240 & 7.764 \\
\hline \multicolumn{2}{|c|}{ Air Content, Non-air-entrained (Entrapped) } & $\mathrm{N} / \mathrm{A}$ & $\mathrm{N} / \mathrm{A}$ & $\mathrm{N} / \mathrm{A}$ & $\mathrm{N} / \mathrm{A}$ & $\mathrm{N} / \mathrm{A}$ & $\mathrm{N} / \mathrm{A}$ & 0.269 \\
\hline Total & & & & & 194 & 3907 & 3907 & 27.000 \\
\hline Superplasticizer & W.R. Grace ADVA 100 & & & & 36 & $\mathrm{ml} / \mathrm{batch}$ & 24.5 & $\mathrm{oz} / \mathrm{yd}^{3}$ \\
\hline
\end{tabular}

\section{Temperature $\left({ }^{\circ} \mathrm{F}\right): \quad 66.0$}

Slump (inches): $\quad 6.250$

Unit Weight $\left(\mathrm{lbs} / \mathrm{ft}^{3}\right): \quad 144.7$

Air Content, Pressure Method (\%): N/A

Air Content, Volumetric Method (\%): $\quad 1.0 \%$

Batch Size $\left(\mathrm{ft}^{3}\right): \quad 1.343$

\begin{tabular}{|c|c|c|c|}
\hline \multicolumn{4}{|c|}{ Moisture Contents } \\
\hline & Sant. Marg. & $\mathrm{R}$ & Sand \\
\hline Pan (g.) & 634.8 & 635.1 & 635.6 \\
\hline Pan+Stock (g.) & 7422.4 & 3806.2 & 6276.6 \\
\hline Pan+OD (g.) & 7401.8 & 3757.2 & 6025.6 \\
\hline M.C. (\%) & $0.3 \%$ & $1.6 \%$ & $4.7 \%$ \\
\hline
\end{tabular}


Table A-4: Batch Record for R45-50

Mix Designation: R45-50

Date Cast: $\quad 7 / 9 / 2010$

Time Cast: $\quad 10: 45$

\begin{tabular}{|c|c|c|c|c|c|c|c|c|}
\hline & \multirow{2}{*}{\multicolumn{4}{|c|}{ "Mixture Proportions }} \\
\hline & & & & & & & & \\
\hline Material & Description & $\begin{array}{l}\text { Specific } \\
\text { Gravity } \\
\end{array}$ & Absorption & $\begin{array}{c}\text { Moisture } \\
\text { Content } \\
\end{array}$ & $\begin{array}{c}\text { Stock WTS } \\
\text { (lbs/batch) }\end{array}$ & $\begin{array}{c}\text { Stock WTS } \\
\left(\mathrm{lbs} / \mathrm{yd}^{3}\right)\end{array}$ & $\begin{array}{c}\text { SSD WTS } \\
\left(\mathrm{lbs} / \mathrm{yd}^{3}\right)\end{array}$ & $\begin{array}{c}\text { ABS Volume } \\
\left(\mathrm{ft}^{3} / \mathrm{yd}^{3}\right)\end{array}$ \\
\hline Cement & Portland Type II/V & 3.15 & N/A & N/A & 80.0 & 713 & 713 & 3.629 \\
\hline Water & Municipal Water & 1.00 & N/A & N/A & 37.0 & 330 & 321 & 5.145 \\
\hline Coarse Aggregates & Santa Margarita 1"x\#4 & 2.61 & $1.4 \%$ & $0.3 \%$ & 89.6 & 799 & 808 & 4.958 \\
\hline Recycled Concrete & $\mathrm{R}$ & 2.47 & $4.9 \%$ & $1.8 \%$ & 83.2 & 742 & 764 & 4.958 \\
\hline Fine Aggregates & Sisquoc C33 Sand & 2.56 & $2.2 \%$ & $4.0 \%$ & 139.7 & 1246 & 1224 & 7.660 \\
\hline \multicolumn{2}{|c|}{ Air Content, Non-air-entrained (Entrapped) } & $\mathrm{N} / \mathrm{A}$ & $\mathrm{N} / \mathrm{A}$ & $\mathrm{N} / \mathrm{A}$ & $\mathrm{N} / \mathrm{A}$ & $\mathrm{N} / \mathrm{A}$ & $\mathrm{N} / \mathrm{A}$ & 0.649 \\
\hline Total & & & & & 429 & 3830 & 3830 & 27.000 \\
\hline Superplasticizer & W.R. Grace ADVA 100 & & & & 65 & $\mathrm{ml} / \mathrm{batch}$ & 19.6 & $\mathrm{oz} / \mathrm{yd}^{3}$ \\
\hline
\end{tabular}

Temperature $\left({ }^{\circ} \mathrm{F}\right): \quad 64.0$

Slump (inches): 8.000

Unit Weight $\left(\mathrm{lbs} / \mathrm{ft}^{3}\right): \quad 141.8$

Air Content, Pressure Method (\%): N/A

Air Content, Volumetric Method (\%): $\quad$ 2.4\%

Batch Size $\left(\mathrm{ft}^{3}\right): \quad 3.028$

\begin{tabular}{|c|c|c|c|}
\hline \multicolumn{4}{|c|}{ Moisture Contents } \\
\hline & Sant. Marg. & $\mathrm{R}$ & Sand \\
\hline Pan (g.) & 632 & 633.6 & 633.4 \\
\hline Pan+Stock (g.) & 5204.4 & 3993.8 & 4617.5 \\
\hline Pan+OD (g.) & 5191.3 & 3933 & 4463.2 \\
\hline M.C. (\%) & $0.3 \%$ & $1.8 \%$ & $4.0 \%$ \\
\hline
\end{tabular}


Table A-5: Batch Record for R45-50

Mix Designation: R45-75

Date Cast: 9/3/2010

Time Cast: $\quad$ 13:00

\begin{tabular}{|c|c|c|c|c|c|c|c|c|}
\hline & & & & & \multirow{2}{*}{\multicolumn{4}{|c|}{ Mixture Proportions }} \\
\hline & & & & & & & & \\
\hline Material & Description & $\begin{array}{c}\text { Specific } \\
\text { Gravity } \\
\end{array}$ & Absorption & $\begin{array}{c}\text { Moisture } \\
\text { Content } \\
\end{array}$ & $\begin{array}{c}\text { Stock WTS } \\
\text { (lbs/batch) } \\
\end{array}$ & $\begin{array}{c}\text { Stock WTS } \\
\left(\mathrm{lbs} / \mathrm{yd}^{3}\right) \\
\end{array}$ & $\begin{array}{c}\text { SSD WTS } \\
\left(\mathrm{lbs} / \mathrm{yd}^{3}\right) \\
\end{array}$ & $\begin{array}{c}\text { ABS Volume } \\
\left(\mathrm{ft}^{3} / \mathrm{yd}^{3}\right) \\
\end{array}$ \\
\hline Cement & Portland Type II/V & 3.15 & $\mathrm{~N} / \mathrm{A}$ & $\mathrm{N} / \mathrm{A}$ & 33.3 & 719 & 719 & 3.660 \\
\hline Water & Municipal Water & 1.00 & $\mathrm{~N} / \mathrm{A}$ & $\mathrm{N} / \mathrm{A}$ & 15.5 & 335 & 323 & 5.182 \\
\hline Coarse Aggregates & Santa Margarita 1"x\#4 & 2.61 & $1.4 \%$ & $0.3 \%$ & 18.7 & 404 & 408 & 2.507 \\
\hline Recycled Concrete & $\mathrm{R}$ & 2.47 & $4.9 \%$ & $1.6 \%$ & 51.9 & 1121 & 1158 & 7.512 \\
\hline Fine Aggregates & Sisquoc C33 Sand & 2.56 & $2.2 \%$ & $4.7 \%$ & 58.6 & 1266 & 1236 & 7.738 \\
\hline \multicolumn{2}{|c|}{ Air Content, Non-air-entrained (Entrapped) } & $\mathrm{N} / \mathrm{A}$ & $\mathrm{N} / \mathrm{A}$ & $\mathrm{N} / \mathrm{A}$ & $\mathrm{N} / \mathrm{A}$ & $\mathrm{N} / \mathrm{A}$ & N/A & 0.400 \\
\hline Total & & & & & 178 & 3845 & 3845 & 27.000 \\
\hline Superplasticizer & W.R. Grace ADVA 100 & & & & 43 & $\mathrm{ml} / \mathrm{batch}$ & 31.4 & $\mathrm{oz} / \mathrm{yd}^{3}$ \\
\hline
\end{tabular}

\section{Temperature $\left({ }^{\circ} \mathrm{F}\right): \quad 66.0$}

Slump (inches): $\quad 6.000$

Unit Weight $\left(\mathrm{lbs} / \mathrm{ft}^{3}\right): \quad 142.4$

Air Content, Pressure Method (\%): N/A

Air Content, Volumetric Method (\%): $\quad 1.5 \%$

Batch Size $\left(\mathrm{ft}^{3}\right): \quad 1.250$

\begin{tabular}{|c|c|c|c|}
\hline \multicolumn{4}{|c|}{ Moisture Contents } \\
\hline & Sant. Marg. & $\mathrm{R}$ & Sand \\
\hline Pan (g.) & 634.8 & 635.1 & 635.6 \\
\hline Pan+Stock (g.) & 7422.4 & 3806.2 & 6276.6 \\
\hline Pan+OD (g.) & 7401.8 & 3757.2 & 6025.6 \\
\hline M.C. (\%) & $0.3 \%$ & $1.6 \%$ & $4.7 \%$ \\
\hline
\end{tabular}


Table A-6: Batch Record for R45-100

Mix Designation: R45-100

Date Cast: $\quad 7 / 16 / 2010$

Time Cast: $11: 45$

\begin{tabular}{|c|c|c|c|c|c|c|c|c|}
\hline & \multirow{2}{*}{\multicolumn{4}{|c|}{ Mixture Proportions }} \\
\hline & & & & & & & & \\
\hline Material & Description & $\begin{array}{l}\text { Specific } \\
\text { Gravity }\end{array}$ & Absorption & $\begin{array}{c}\text { Moisture } \\
\text { Content }\end{array}$ & $\begin{array}{c}\text { Stock WTS } \\
\text { (lbs/batch) }\end{array}$ & $\begin{array}{c}\text { Stock WTS } \\
\left(\mathrm{lbs} / \mathrm{yd}^{3}\right)\end{array}$ & $\begin{array}{c}\text { SSD WTS } \\
\left(1 \mathrm{bs} / \mathrm{yd}^{3}\right)\end{array}$ & $\begin{array}{c}\text { ABS Volume } \\
\left(\mathrm{ft}^{3} / \mathrm{yd}^{3}\right)\end{array}$ \\
\hline Cement & Portland Type II/V & 3.15 & N/A & N/A & 69.3 & 718 & 718 & 3.654 \\
\hline Water & Municipal Water & 1.00 & $\mathrm{~N} / \mathrm{A}$ & $\mathrm{N} / \mathrm{A}$ & 33.1 & 343 & 323 & 5.180 \\
\hline Coarse Aggregates & $\mathrm{N} / \mathrm{A}$ & 2.61 & $1.4 \%$ & $0.0 \%$ & 0.0 & 0 & 0 & 0.000 \\
\hline Recycled Concrete & $\mathrm{R}$ & 2.47 & $4.9 \%$ & $2.1 \%$ & 144.5 & 1497 & 1539 & 9.985 \\
\hline Fine Aggregates & Sisquoc C33 Sand & 2.56 & $2.2 \%$ & $4.0 \%$ & 121.0 & 1254 & 1232 & 7.713 \\
\hline \multicolumn{2}{|c|}{ Air Content, Non-air-entrained (Entrapped) } & $\mathrm{N} / \mathrm{A}$ & $\mathrm{N} / \mathrm{A}$ & $\mathrm{N} / \mathrm{A}$ & $\mathrm{N} / \mathrm{A}$ & $\mathrm{N} / \mathrm{A}$ & $\mathrm{N} / \mathrm{A}$ & 0.468 \\
\hline Total & & & & & 368 & 3813 & 3813 & 27.000 \\
\hline Superplasticizer & W.R. Grace ADVA 100 & & & & 110 & $\mathrm{ml} / \mathrm{batch}$ & 38.5 & $\mathrm{oz} / \mathrm{yd}^{3}$ \\
\hline
\end{tabular}

Temperature $\left({ }^{\circ} \mathrm{F}\right): \quad 64.5$

Slump (inches): $\quad 6.000$

Unit Weight $\left(\mathrm{lbs} / \mathrm{ft}^{3}\right): \quad 141.2$

Air Content, Pressure Method (\%): N/A

Air Content, Volumetric Method (\%): $\quad$ 1.7\%

Batch Size $\left(\mathrm{ft}^{3}\right): \quad 2.606$

\begin{tabular}{|c|c|c|c|}
\hline \multicolumn{4}{|c|}{ Moisture Contents } \\
\hline & N/A & R & Sand \\
\hline Pan (g.) & 0 & 555.3 & 634.7 \\
\hline Pan+Stock (g.) & 1 & 4203.7 & 3181.2 \\
\hline Pan+OD (g.) & 1 & 4129.9 & 3083.1 \\
\hline M.C. (\%) & $0.0 \%$ & $2.1 \%$ & $4.0 \%$ \\
\hline
\end{tabular}


Table A-7: Batch Record for RS45-50

Mix Designation: RS45-50

Date Cast: $\quad$ 9/26/2010

Time Cast: $\quad$ 11:00

\begin{tabular}{|c|c|c|c|c|c|c|c|c|}
\hline & & & & & \multirow{2}{*}{\multicolumn{4}{|c|}{ Mixture Proportions }} \\
\hline & & & & & & & & \\
\hline Material & Description & $\begin{array}{c}\text { Specific } \\
\text { Gravity } \\
\end{array}$ & Absorption & $\begin{array}{c}\text { Moisture } \\
\text { Content } \\
\end{array}$ & $\begin{array}{c}\text { Stock WTS } \\
\text { (lbs/batch) } \\
\end{array}$ & $\begin{array}{c}\text { Stock WTS } \\
\left(\mathrm{lbs} / \mathrm{yd}^{3}\right) \\
\end{array}$ & $\begin{array}{c}\text { SSD WTS } \\
\left(\mathrm{lbs} / \mathrm{yd}^{3}\right) \\
\end{array}$ & $\begin{array}{c}\text { ABS Volume } \\
\left(\mathrm{ft}^{3} / \mathrm{yd}^{3}\right) \\
\end{array}$ \\
\hline Cement & Portland Type II/V & 3.15 & $\mathrm{~N} / \mathrm{A}$ & $\mathrm{N} / \mathrm{A}$ & 33.3 & 727 & 727 & 3.699 \\
\hline Water & Municipal Water & 1.00 & $\mathrm{~N} / \mathrm{A}$ & $\mathrm{N} / \mathrm{A}$ & 13.3 & 290 & 328 & 5.258 \\
\hline Coarse Aggregates & Santa Margarita 1"x\#4 & 2.61 & $1.4 \%$ & $0.3 \%$ & 37.3 & 814 & 824 & 5.057 \\
\hline Recycled Concrete & RS & 2.44 & $5.4 \%$ & $9.4 \%$ & 36.6 & 799 & 770 & 5.057 \\
\hline Fine Aggregates & Sisquoc C33 Sand & 2.56 & $2.2 \%$ & $3.7 \%$ & 58.0 & 1266 & 1248 & 7.815 \\
\hline \multicolumn{2}{|c|}{ Air Content, Non-air-entrained (Entrapped) } & $\mathrm{N} / \mathrm{A}$ & $\mathrm{N} / \mathrm{A}$ & $\mathrm{N} / \mathrm{A}$ & $\mathrm{N} / \mathrm{A}$ & $\mathrm{N} / \mathrm{A}$ & N/A & 0.114 \\
\hline Total & & & & & 179 & 3897 & 3897 & 27.000 \\
\hline Superplasticizer & W.R. Grace ADVA 100 & & & & 15 & $\mathrm{ml} / \mathrm{batch}$ & 11.1 & $\mathrm{oz} / \mathrm{yd}^{3}$ \\
\hline
\end{tabular}

Temperature $\left({ }^{\circ} \mathrm{F}\right): \quad 80.0$

Slump (inches): $\quad 6.000$

Unit Weight $\left(\mathrm{lbs} / \mathrm{ft}^{3}\right): \quad 144.3$

Air Content, Pressure Method (\%): N/A

Air Content, Volumetric Method (\%): $\quad 0.4 \%$

Batch Size $\left(\mathrm{ft}^{3}\right): \quad 1.237$

\begin{tabular}{|c|c|c|c|}
\hline \multicolumn{4}{|c|}{ Moisture Contents } \\
\hline & Sant. Marg. & RS & Sand \\
\hline Pan (g.) & 556.8 & 970 & 557.5 \\
\hline Pan+Stock (g.) & 3952 & 9878.9 & 6117 \\
\hline Pan+OD (g.) & 3943 & 9115.2 & 5920.4 \\
\hline M.C. (\%) & $0.3 \%$ & $9.4 \%$ & $3.7 \%$ \\
\hline
\end{tabular}


Table A-8: Batch Record for RS45-100

Mix Designation: RS45-100

Date Cast: 9/26/2010

Time Cast: $\quad$ 11:30

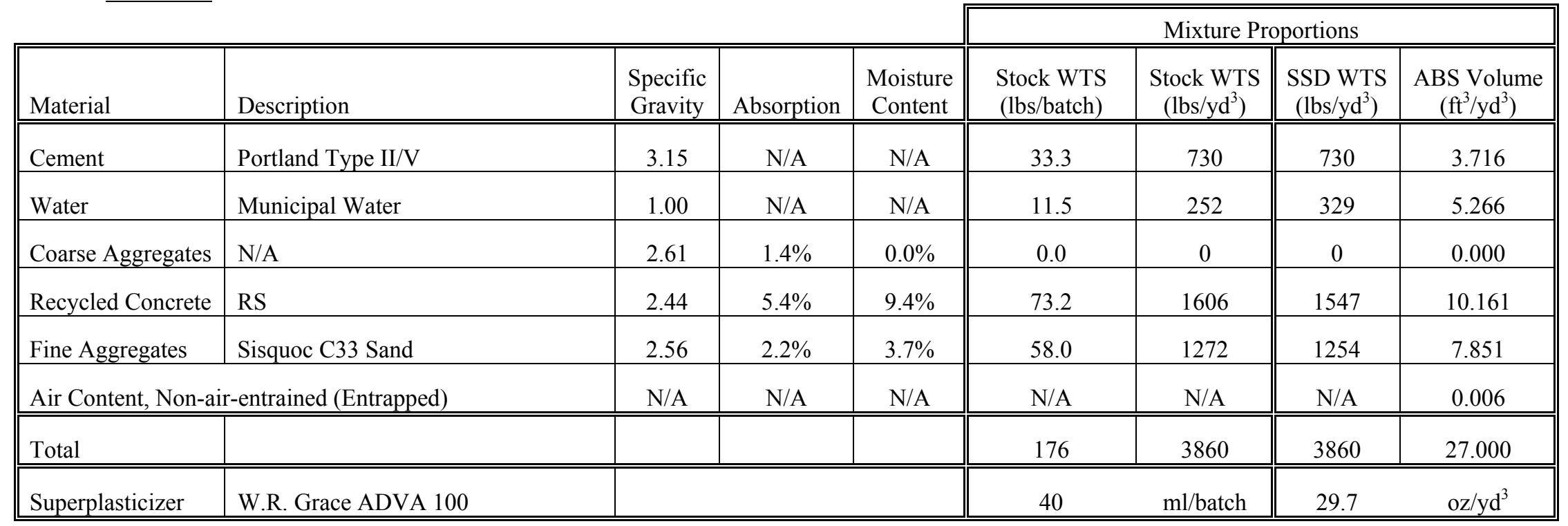

Temperature $\left({ }^{\circ} \mathrm{F}\right): \quad 80.0$

Slump (inches): $\quad 6.000$

Unit Weight $\left(\mathrm{lbs} / \mathrm{ft}^{3}\right): \quad 143.0$

Air Content, Pressure Method (\%): N/A

Air Content, Volumetric Method (\%): $\quad 0.0 \%$

Batch Size $\left(\mathrm{ft}^{3}\right): \quad 1.231$

\begin{tabular}{|c|c|c|c|}
\hline \multicolumn{4}{|c|}{ Moisture Contents } \\
\hline & N/A & RS & Sand \\
\hline Pan (g.) & 0 & 970 & 557.5 \\
\hline Pan+Stock (g.) & 1 & 9878.9 & 6117 \\
\hline Pan+OD (g.) & 1 & 9115.2 & 5920.4 \\
\hline M.C. (\%) & $0.0 \%$ & $9.4 \%$ & $3.7 \%$ \\
\hline
\end{tabular}


Table A-9: Batch Record for RD45-50

Mix Designation: RD45-50

Date Cast: $\quad$ 9/26/2010

Time Cast: $\quad$ 12:00

\begin{tabular}{|c|c|c|c|c|c|c|c|c|}
\hline & & & & & \multirow{2}{*}{\multicolumn{4}{|c|}{ Mixture Proportions }} \\
\hline & & & & & & & & \\
\hline Material & Description & $\begin{array}{c}\text { Specific } \\
\text { Gravity } \\
\end{array}$ & Absorption & $\begin{array}{c}\text { Moisture } \\
\text { Content } \\
\end{array}$ & $\begin{array}{c}\text { Stock WTS } \\
\text { (lbs/batch) } \\
\end{array}$ & $\begin{array}{c}\text { Stock WTS } \\
\left(\mathrm{lbs} / \mathrm{yd}^{3}\right) \\
\end{array}$ & $\begin{array}{c}\text { SSD WTS } \\
\left(\mathrm{lbs} / \mathrm{yd}^{3}\right) \\
\end{array}$ & $\begin{array}{c}\text { ABS Volume } \\
\left(\mathrm{ft}^{3} / \mathrm{yd}^{3}\right) \\
\end{array}$ \\
\hline Cement & Portland Type II/V & 3.15 & $\mathrm{~N} / \mathrm{A}$ & $\mathrm{N} / \mathrm{A}$ & 33.3 & 720 & 720 & 3.664 \\
\hline Water & Municipal Water & 1.00 & N/A & $\mathrm{N} / \mathrm{A}$ & 16.2 & 350 & 324 & 5.189 \\
\hline Coarse Aggregates & Santa Margarita 1"x\#4 & 2.61 & $1.4 \%$ & $0.3 \%$ & 37.3 & 807 & 816 & 5.009 \\
\hline Recycled Concrete & $\mathrm{RD}$ & 2.43 & $5.3 \%$ & $0.4 \%$ & 33.5 & 724 & 760 & 5.010 \\
\hline Fine Aggregates & Sisquoc C33 Sand & 2.56 & $2.2 \%$ & $3.7 \%$ & 58.0 & 1254 & 1237 & 7.741 \\
\hline \multicolumn{2}{|c|}{ Air Content, Non-air-entrained (Entrapped) } & $\mathrm{N} / \mathrm{A}$ & $\mathrm{N} / \mathrm{A}$ & $\mathrm{N} / \mathrm{A}$ & $\mathrm{N} / \mathrm{A}$ & $\mathrm{N} / \mathrm{A}$ & N/A & 0.388 \\
\hline Total & & & & & 178 & 3856 & 3856 & 27.000 \\
\hline Superplasticizer & W.R. Grace ADVA 100 & & & & 28 & $\mathrm{ml} / \mathrm{batch}$ & 20.5 & $\mathrm{oz} / \mathrm{yd}^{3}$ \\
\hline
\end{tabular}

Temperature $\left({ }^{\circ} \mathrm{F}\right): \quad 80.0$

Slump (inches): $\quad 7.000$

Unit Weight $\left(\mathrm{lbs} / \mathrm{ft}^{3}\right): \quad 142.8$

Air Content, Pressure Method (\%): N/A

Air Content, Volumetric Method (\%): $\quad 1.4 \%$

Batch Size $\left(\mathrm{ft}^{3}\right): \quad 1.249$

\begin{tabular}{|c|c|c|c|}
\hline \multicolumn{4}{|c|}{ Moisture Contents } \\
\hline & Sant. Marg. & RD & Sand \\
\hline Pan (g.) & 556.8 & 976 & 557.5 \\
\hline Pan+Stock (g.) & 3952 & 5690.4 & 6117 \\
\hline Pan+OD (g.) & 3943 & 5670.4 & 5920.4 \\
\hline M.C. (\%) & $0.3 \%$ & $0.4 \%$ & $3.7 \%$ \\
\hline
\end{tabular}


Table A-10: Batch Record for RD45-100

Mix Designation: RD45-100

Date Cast: 9/26/2010

Time Cast: $\quad 12: 30$

\begin{tabular}{|c|c|c|c|c|c|c|c|c|}
\hline & \multirow{2}{*}{\multicolumn{4}{|c|}{ Mixture Proportions }} \\
\hline & & & & & & & & \\
\hline Material & Description & $\begin{array}{l}\text { Specific } \\
\text { Gravity }\end{array}$ & Absorption & $\begin{array}{c}\text { Moisture } \\
\text { Content }\end{array}$ & $\begin{array}{c}\text { Stock WTS } \\
\text { (lbs/batch) }\end{array}$ & $\begin{array}{c}\text { Stock WTS } \\
\left(\mathrm{lbs} / \mathrm{yd}^{3}\right)\end{array}$ & $\begin{array}{c}\text { SSD WTS } \\
\left(1 \mathrm{bs} / \mathrm{yd}^{3}\right)\end{array}$ & $\begin{array}{c}\text { ABS Volume } \\
\left(\mathrm{ft}^{3} / \mathrm{yd}^{3}\right)\end{array}$ \\
\hline Cement & Portland Type II/V & 3.15 & N/A & N/A & 33.3 & 728 & 728 & 3.705 \\
\hline Water & Municipal Water & 1.00 & $\mathrm{~N} / \mathrm{A}$ & $\mathrm{N} / \mathrm{A}$ & 17.4 & 381 & 327 & 5.247 \\
\hline Coarse Aggregates & $\mathrm{N} / \mathrm{A}$ & 2.61 & $1.4 \%$ & $0.0 \%$ & 0.0 & 0 & 0 & 0.000 \\
\hline Recycled Concrete & $\mathrm{RD}$ & 2.43 & $5.3 \%$ & $0.4 \%$ & 67.0 & 1465 & 1537 & 10.133 \\
\hline Fine Aggregates & Sisquoc C33 Sand & 2.56 & $2.2 \%$ & $3.7 \%$ & 58.0 & 1269 & 1251 & 7.829 \\
\hline \multicolumn{2}{|c|}{ Air Content, Non-air-entrained (Entrapped) } & $\mathrm{N} / \mathrm{A}$ & $\mathrm{N} / \mathrm{A}$ & $\mathrm{N} / \mathrm{A}$ & $\mathrm{N} / \mathrm{A}$ & $\mathrm{N} / \mathrm{A}$ & $\mathrm{N} / \mathrm{A}$ & 0.086 \\
\hline Total & & & & & 176 & 3843 & 3843 & 27.000 \\
\hline Superplasticizer & W.R. Grace ADVA 100 & & & & 35 & $\mathrm{ml} / \mathrm{batch}$ & 25.9 & $\mathrm{oz} / \mathrm{yd}^{3}$ \\
\hline
\end{tabular}

$\begin{array}{rc}\text { Temperature }\left({ }^{\circ} \mathrm{F}\right): & 81.0 \\ \text { Slump (inches): } & 7.000 \\ \text { Unit Weight }\left(\mathrm{lbs} / \mathrm{ft}^{3}\right): & 142.3 \\ \text { Pressure Method }(\%): & \text { N/A } \\ \text { lumetric Method }(\%): & 0.3 \% \\ \text { Batch Size }\left(\mathrm{ft}^{3}\right): & 1.234\end{array}$

\begin{tabular}{|c|c|c|c|}
\hline \multicolumn{4}{|c|}{ Moisture Contents } \\
\hline & N/A & RD & Sand \\
\hline Pan (g.) & 0 & 976 & 557.5 \\
\hline Pan+Stock (g.) & 1 & 5690.4 & 6117 \\
\hline Pan+OD (g.) & 1 & 5670.4 & 5920.4 \\
\hline M.C. (\%) & $0.0 \%$ & $0.4 \%$ & $3.7 \%$ \\
\hline
\end{tabular}

Air Content, Pressure Method (\%): N/A

Air Content, Volumetric Method (\%): $\quad 0.3 \%$

Batch Size $\left(\mathrm{ft}^{3}\right): \quad 1.234$ 
Table A-11: Batch Record for RID45-100

Mix Designation: RLD45-100

Date Cast: $\quad 9 / 26 / 2010$

Time Cast: $\quad$ 13:00

\begin{tabular}{|c|c|c|c|c|c|c|c|c|}
\hline & \multirow{2}{*}{\multicolumn{4}{|c|}{ Mixture Proportions }} \\
\hline & & & & & & & & \\
\hline Material & Description & $\begin{array}{l}\text { Specific } \\
\text { Gravity }\end{array}$ & Absorption & $\begin{array}{c}\text { Moisture } \\
\text { Content }\end{array}$ & $\begin{array}{c}\text { Stock WTS } \\
\text { (lbs/batch) }\end{array}$ & $\begin{array}{c}\text { Stock WTS } \\
\left(\mathrm{lbs} / \mathrm{yd}^{3}\right)\end{array}$ & $\begin{array}{c}\text { SSD WTS } \\
\left(1 \mathrm{bs} / \mathrm{yd}^{3}\right)\end{array}$ & $\begin{array}{c}\text { ABS Volume } \\
\left(\mathrm{ft}^{3} / \mathrm{yd}^{3}\right)\end{array}$ \\
\hline Cement & Portland Type II/V & 3.15 & N/A & N/A & 33.3 & 725 & 725 & 3.686 \\
\hline Water & Municipal Water & 1.00 & $\mathrm{~N} / \mathrm{A}$ & $\mathrm{N} / \mathrm{A}$ & 17.2 & 375 & 326 & 5.225 \\
\hline Coarse Aggregates & $\mathrm{N} / \mathrm{A}$ & 2.61 & $1.4 \%$ & $0.0 \%$ & 0.0 & 0 & 0 & 0.000 \\
\hline Recycled Concrete & RLD & 2.46 & $4.7 \%$ & $0.2 \%$ & 68.1 & 1480 & 1546 & 10.071 \\
\hline Fine Aggregates & Sisquoc C33 Sand & 2.56 & $2.2 \%$ & $3.7 \%$ & 58.0 & 1261 & 1243 & 7.780 \\
\hline \multicolumn{2}{|c|}{ Air Content, Non-air-entrained (Entrapped) } & $\mathrm{N} / \mathrm{A}$ & $\mathrm{N} / \mathrm{A}$ & $\mathrm{N} / \mathrm{A}$ & $\mathrm{N} / \mathrm{A}$ & $\mathrm{N} / \mathrm{A}$ & $\mathrm{N} / \mathrm{A}$ & 0.237 \\
\hline Total & & & & & 177 & 3839 & 3839 & 27.000 \\
\hline Superplasticizer & W.R. Grace ADVA 100 & & & & 30 & $\mathrm{ml} / \mathrm{batch}$ & 22.0 & $\mathrm{oz} / \mathrm{yd}^{3}$ \\
\hline
\end{tabular}

Temperature $\left({ }^{\circ} \mathrm{F}\right): \quad 70.0$

Slump (inches): $\quad 7.000$

Unit Weight $\left(\mathrm{lbs} / \mathrm{ft}^{3}\right): \quad 142.2$

Air Content, Pressure Method (\%): N/A

Air Content, Volumetric Method (\%): $\quad 0.9 \%$

Batch Size $\left(\mathrm{ft}^{3}\right): \quad 1.242$

\begin{tabular}{|c|c|c|c|}
\hline \multicolumn{4}{|c|}{ Moisture Contents } \\
\hline & N/A & RLD & Sand \\
\hline Pan (g.) & 0 & 972 & 557.5 \\
\hline Pan+Stock (g.) & 1 & 7685.9 & 6117 \\
\hline Pan+OD (g.) & 1 & 7671.8 & 5920.4 \\
\hline M.C. (\%) & $0.0 \%$ & $0.2 \%$ & $3.7 \%$ \\
\hline
\end{tabular}


Table A-12: Batch Record for RHD45-100

Mix Designation: RHD45-100

Date Cast: $\quad 10 / 1 / 2010$

Time Cast: $\quad 8: 45$

\begin{tabular}{|c|c|c|c|c|c|c|c|c|}
\hline & \multirow{2}{*}{\multicolumn{4}{|c|}{ Mixture Proportions }} \\
\hline & & & & & & & & \\
\hline Material & Description & $\begin{array}{l}\text { Specific } \\
\text { Gravity }\end{array}$ & Absorption & $\begin{array}{c}\text { Moisture } \\
\text { Content }\end{array}$ & $\begin{array}{c}\text { Stock WTS } \\
\text { (lbs/batch) }\end{array}$ & $\begin{array}{c}\text { Stock WTS } \\
\left(\mathrm{lbs} / \mathrm{yd}^{3}\right)\end{array}$ & $\begin{array}{c}\text { SSD WTS } \\
\left(1 \mathrm{bs} / \mathrm{yd}^{3}\right)\end{array}$ & $\begin{array}{c}\text { ABS Volume } \\
\left(\mathrm{ft}^{3} / \mathrm{yd}^{3}\right)\end{array}$ \\
\hline Cement & Portland Type II/V & 3.15 & N/A & N/A & 33.3 & 724 & 724 & 3.683 \\
\hline Water & Municipal Water & 1.00 & $\mathrm{~N} / \mathrm{A}$ & $\mathrm{N} / \mathrm{A}$ & 17.4 & 377 & 326 & 5.220 \\
\hline Coarse Aggregates & $\mathrm{N} / \mathrm{A}$ & 2.61 & $1.4 \%$ & $0.0 \%$ & 0.0 & 0 & 0 & 0.000 \\
\hline Recycled Concrete & RHD & 2.44 & $5.1 \%$ & $0.3 \%$ & 67.3 & 1462 & 1532 & 10.062 \\
\hline Fine Aggregates & Sisquoc C33 Sand & 2.56 & $2.2 \%$ & $3.7 \%$ & 58.0 & 1259 & 1242 & 7.773 \\
\hline \multicolumn{2}{|c|}{ Air Content, Non-air-entrained (Entrapped) } & $\mathrm{N} / \mathrm{A}$ & $\mathrm{N} / \mathrm{A}$ & $\mathrm{N} / \mathrm{A}$ & $\mathrm{N} / \mathrm{A}$ & $\mathrm{N} / \mathrm{A}$ & $\mathrm{N} / \mathrm{A}$ & 0.263 \\
\hline Total & & & & & 176 & 3823 & 3823 & 27.000 \\
\hline Superplasticizer & W.R. Grace ADVA 100 & & & & 33 & $\mathrm{ml} / \mathrm{batch}$ & 24.2 & $\mathrm{oz} / \mathrm{yd}^{3}$ \\
\hline
\end{tabular}

Temperature $\left({ }^{\circ} \mathrm{F}\right): \quad 71.0$

Slump (inches): $\quad 6.000$

Unit Weight $\left(\mathrm{lbs} / \mathrm{ft}^{3}\right): \quad 141.6$

Air Content, Pressure Method (\%): N/A

Air Content, Volumetric Method (\%): $\quad 1.0 \%$

Batch Size $\left(\mathrm{ft}^{3}\right): \quad 1.243$

\begin{tabular}{|c|c|c|c|}
\hline \multicolumn{4}{|c|}{ Moisture Contents } \\
\hline & N/A & RHD & Sand \\
\hline Pan (g.) & 0 & 693.9 & 557.5 \\
\hline Pan+Stock (g.) & 1 & 3167.7 & 6117 \\
\hline Pan+OD (g.) & 1 & 3159.5 & 5920.4 \\
\hline M.C. (\%) & $0.0 \%$ & $0.3 \%$ & $3.7 \%$ \\
\hline
\end{tabular}


Table A-13: Batch Record for N60

Mix Designation: $\quad$ N60

Date Cast: $\quad 7 / 30 / 2010$

Time Cast: $\quad$ 12:45

\begin{tabular}{|c|c|c|c|c|c|c|c|c|}
\hline & \multirow{2}{*}{\multicolumn{4}{|c|}{ Mixture Proportions }} \\
\hline & & & & & & & & \\
\hline Material & Description & $\begin{array}{l}\text { Specific } \\
\text { Gravity }\end{array}$ & Absorption & $\begin{array}{c}\text { Moisture } \\
\text { Content }\end{array}$ & $\begin{array}{c}\text { Stock WTS } \\
\text { (lbs/batch) }\end{array}$ & $\begin{array}{c}\text { Stock WTS } \\
\left(\mathrm{lbs} / \mathrm{yd}^{3}\right)\end{array}$ & $\begin{array}{c}\text { SSD WTS } \\
\left(1 \mathrm{bs} / \mathrm{yd}^{3}\right)\end{array}$ & $\begin{array}{c}\text { ABS Volume } \\
\left(\mathrm{ft}^{3} / \mathrm{yd}^{3}\right)\end{array}$ \\
\hline Cement & Portland Type II/V & 3.15 & $\mathrm{~N} / \mathrm{A}$ & N/A & 52.0 & 532 & 532 & 2.707 \\
\hline Water & Municipal Water & 1.00 & $\mathrm{~N} / \mathrm{A}$ & $\mathrm{N} / \mathrm{A}$ & 30.6 & 313 & 327 & 5.234 \\
\hline Coarse Aggregates & Santa Margarita 1"x\#4 & 2.61 & $1.4 \%$ & $0.3 \%$ & 155.3 & 1589 & 1606 & 9.860 \\
\hline Recycled Concrete & N/A & 2.47 & $4.9 \%$ & $0.0 \%$ & 0.0 & 0 & 0 & 0.000 \\
\hline Fine Aggregates & Sisquoc C33 Sand & 2.56 & $2.2 \%$ & $4.5 \%$ & 135.3 & 1384 & 1354 & 8.473 \\
\hline \multicolumn{2}{|c|}{ Air Content, Non-air-entrained (Entrapped) } & $\mathrm{N} / \mathrm{A}$ & $\mathrm{N} / \mathrm{A}$ & $\mathrm{N} / \mathrm{A}$ & $\mathrm{N} / \mathrm{A}$ & $\mathrm{N} / \mathrm{A}$ & $\mathrm{N} / \mathrm{A}$ & 0.726 \\
\hline Total & & & & & 373 & 3818 & 3818 & 27.000 \\
\hline Superplasticizer & W.R. Grace ADVA 100 & & & & 25 & $\mathrm{ml} / \mathrm{batch}$ & 8.6 & $\mathrm{oz} / \mathrm{yd}^{3}$ \\
\hline
\end{tabular}

Temperature $\left({ }^{\circ} \mathrm{F}\right): \quad 73.0$

Slump (inches): $\quad 6.000$

Unit Weight $\left(\mathrm{lbs} / \mathrm{ft}^{3}\right): \quad 141.4$

Air Content, Pressure Method (\%): N/A

Air Content, Volumetric Method (\%): $\quad 2.7 \%$

Batch Size $\left(\mathrm{ft}^{3}\right): \quad 2.639$

\begin{tabular}{|c|c|c|c|}
\hline \multicolumn{4}{|c|}{ Moisture Contents } \\
\hline & Sant. Marg. & N/A & Sand \\
\hline Pan (g.) & 634.7 & 0 & 555.4 \\
\hline Pan+Stock (g.) & 4280.5 & 1 & 3152.3 \\
\hline Pan+OD (g.) & 4269.1 & 1 & 3040.7 \\
\hline M.C. (\%) & $0.3 \%$ & $0.0 \%$ & $4.5 \%$ \\
\hline
\end{tabular}


Table A-14: Batch Record for R60-100

Mix Designation: $\quad$ R60-100

Date Cast: $\quad 8 / 6 / 2010$

Time Cast: $\quad 10: 30$

\begin{tabular}{|c|c|c|c|c|c|c|c|c|}
\hline & \multirow{2}{*}{\multicolumn{4}{|c|}{ Mixture Proportions }} \\
\hline & & & & & & & & \\
\hline Material & Description & $\begin{array}{l}\text { Specific } \\
\text { Gravity } \\
\end{array}$ & Absorption & \begin{tabular}{|c|} 
Moisture \\
Content \\
\end{tabular} & $\begin{array}{c}\text { Stock WTS } \\
\text { (lbs/batch) }\end{array}$ & $\begin{array}{c}\text { Stock WTS } \\
\left(\mathrm{lbs} / \mathrm{yd}^{3}\right) \\
\end{array}$ & $\begin{array}{c}\text { SSD WTS } \\
\left(1 \mathrm{bs} / \mathrm{yd}^{3}\right)\end{array}$ & $\begin{array}{c}\text { ABS Volume } \\
\left(\mathrm{ft}^{3} / \mathrm{yd}^{3}\right)\end{array}$ \\
\hline Cement & Portland Type II/V & 3.15 & N/A & N/A & 52.0 & 539 & 539 & 2.744 \\
\hline Water & Municipal Water & 1.00 & N/A & $\mathrm{N} / \mathrm{A}$ & 33.2 & 345 & 324 & 5.186 \\
\hline Coarse Aggregates & N/A & 2.61 & $1.4 \%$ & $0.0 \%$ & 0.0 & 0 & 0 & 0.000 \\
\hline Recycled Concrete & $\mathrm{R}$ & 2.47 & $4.9 \%$ & $1.9 \%$ & 144.3 & 1496 & 1541 & 9.996 \\
\hline Fine Aggregates & Sisquoc C33 Sand & 2.56 & $2.2 \%$ & $3.9 \%$ & 135.3 & 1403 & 1380 & 8.637 \\
\hline \multicolumn{2}{|c|}{ Air Content, Non-air-entrained (Entrapped) } & N/A & N/A & $\mathrm{N} / \mathrm{A}$ & $\mathrm{N} / \mathrm{A}$ & $\mathrm{N} / \mathrm{A}$ & $\mathrm{N} / \mathrm{A}$ & 0.438 \\
\hline Total & & & & & 365 & 3783 & 3783 & 27.000 \\
\hline Superplasticizer & W.R. Grace ADVA 100 & & & & 30 & $\mathrm{ml} / \mathrm{batch}$ & 10.5 & $\mathrm{oz} / \mathrm{yd}^{3}$ \\
\hline
\end{tabular}

Temperature $\left({ }^{\circ} \mathrm{F}\right): \quad 63.3$

Slump (inches): $\quad 7.250$

Unit Weight $\left(\mathrm{lbs} / \mathrm{ft}^{3}\right): \quad 140.1$

Air Content, Pressure Method (\%): N/A

Air Content, Volumetric Method (\%): $\quad$ 1.6\%

Batch Size $\left(\mathrm{ft}^{3}\right): \quad 2.603$

\begin{tabular}{|c|c|c|c|}
\hline \multicolumn{4}{|c|}{ Moisture Contents } \\
\hline & N/A & R & Sand \\
\hline Pan (g.) & 0 & 555.4 & 634.7 \\
\hline Pan+Stock (g.) & 1 & 5722.9 & 3204.5 \\
\hline Pan+OD (g.) & 1 & 5627.1 & 3107.4 \\
\hline M.C. (\%) & $0.0 \%$ & $1.9 \%$ & $3.9 \%$ \\
\hline
\end{tabular}


Table A-15: Batch Record for RS60-100

Mix Designation: RS60-100

Date Cast: $\quad$ 9/25/2010

Time Cast: $\quad$ 12:00

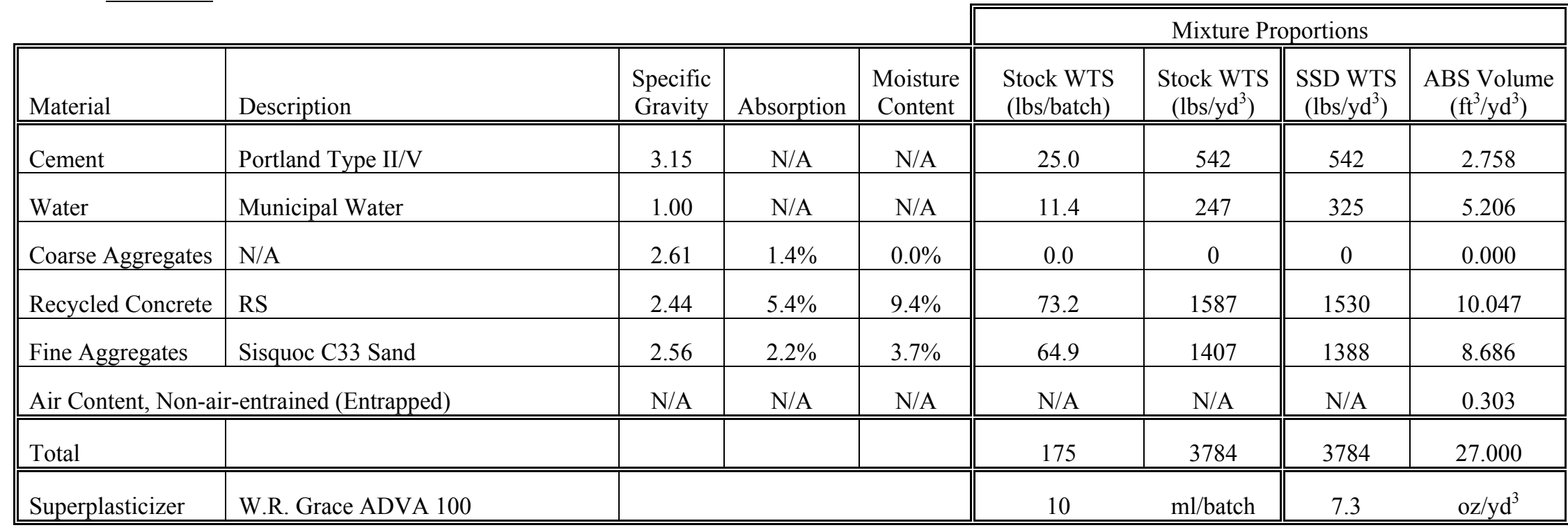

Temperature $\left({ }^{\circ} \mathrm{F}\right): \quad 75.0$

Slump (inches): $\quad 6.000$

Unit Weight $\left(\mathrm{lbs} / \mathrm{ft}^{3}\right): \quad 140.2$

Air Content, Pressure Method (\%): N/A

Air Content, Volumetric Method (\%): $\quad 1.1 \%$

Batch Size $\left(\mathrm{ft}^{3}\right): \quad 1.245$

\begin{tabular}{|c|c|c|c|}
\hline \multicolumn{4}{|c|}{ Moisture Contents } \\
\hline & N/A & RS & Sand \\
\hline Pan (g.) & 0 & 970 & 557.5 \\
\hline Pan+Stock (g.) & 1 & 9878.9 & 6117 \\
\hline Pan+OD (g.) & 1 & 9115.2 & 5920.4 \\
\hline M.C. (\%) & $0.0 \%$ & $9.4 \%$ & $3.7 \%$ \\
\hline
\end{tabular}


Table A-16: Batch Record for RD60-100

Mix Designation: RD60-100

Date Cast: $\quad$ 9/25/2010

Time Cast: $\quad 12: 30$

\begin{tabular}{|c|c|c|c|c|c|c|c|c|}
\hline \multirow[b]{2}{*}{ Material } & \multirow[b]{2}{*}{ Description } & \multirow[b]{2}{*}{$\begin{array}{l}\begin{array}{l}\text { Specific } \\
\text { Gravity }\end{array} \\
\end{array}$} & \multirow[b]{2}{*}{ Absorption } & \multirow[b]{2}{*}{$\begin{array}{c}\text { Moisture } \\
\text { Content }\end{array}$} & \multicolumn{4}{|c|}{ Mixture Proportions } \\
\hline & & & & & $\begin{array}{l}\text { Stock WTS } \\
\text { (lbs/batch) }\end{array}$ & $\begin{array}{c}\text { Stock WTS } \\
\left(\mathrm{lbs} / \mathrm{yd}^{3}\right)\end{array}$ & $\begin{array}{l}\text { SSD WTS } \\
\left(\mathrm{lbs} / \mathrm{yd}^{3}\right)\end{array}$ & $\begin{array}{l}\text { ABS Volume } \\
\left(\mathrm{ft}^{3} / \mathrm{yd}^{3}\right)\end{array}$ \\
\hline Cement & Portland Type II/V & 3.15 & N/A & N/A & 25.0 & 539 & 539 & 2.744 \\
\hline Water & Municipal Water & 1.00 & N/A & N/A & 17.3 & 373 & 323 & 5.174 \\
\hline Coarse Aggregates & N/A & 2.61 & $1.4 \%$ & $0.0 \%$ & 0.0 & 0 & 0 & 0.000 \\
\hline Recycled Concrete & $\mathrm{RD}$ & 2.43 & $5.3 \%$ & $0.4 \%$ & 67.0 & 1446 & 1516 & 9.996 \\
\hline Fine Aggregates & Sisquoc C33 Sand & 2.56 & $2.2 \%$ & $3.7 \%$ & 64.9 & 1400 & 1380 & 8.641 \\
\hline \multicolumn{2}{|c|}{ Air Content, Non-air-entrained (Entrapped) } & $\mathrm{N} / \mathrm{A}$ & $\mathrm{N} / \mathrm{A}$ & $\mathrm{N} / \mathrm{A}$ & $\mathrm{N} / \mathrm{A}$ & $\mathrm{N} / \mathrm{A}$ & $\mathrm{N} / \mathrm{A}$ & 0.444 \\
\hline Total & & & & & 174 & 3758 & 3758 & 27.000 \\
\hline Superplasticizer & W.R. Grace ADVA 100 & & & & 11 & $\mathrm{ml} /$ batch & 8.0 & $\mathrm{oz} / \mathrm{yd}^{3}$ \\
\hline
\end{tabular}

Temperature $\left({ }^{\circ} \mathrm{F}\right): \quad 75.0$

Slump (inches): $\quad 6.500$

Unit Weight $\left(\mathrm{lbs} / \mathrm{ft}^{3}\right): \quad 139.2$

Air Content, Pressure Method (\%): N/A

Air Content, Volumetric Method (\%): $\quad 1.6 \%$

Batch Size $\left(\mathrm{ft}^{3}\right): \quad 1.251$

\begin{tabular}{|c|c|c|c|}
\hline \multicolumn{4}{|c|}{ Moisture Contents } \\
\hline & N/A & RD & Sand \\
\hline Pan (g.) & 0 & 976 & 557.5 \\
\hline Pan+Stock (g.) & 1 & 5690.4 & 6117 \\
\hline Pan+OD (g.) & 1 & 5670.4 & 5920.4 \\
\hline M.C. (\%) & $0.0 \%$ & $0.4 \%$ & $3.7 \%$ \\
\hline
\end{tabular}


Table A-17: Batch Record for N30

Mix Designation: N30

Date Cast: $\quad 8 / 20 / 2010$

Time Cast: 11:00

\begin{tabular}{|c|c|c|c|c|c|c|c|c|}
\hline & & & & & \multirow{2}{*}{\multicolumn{4}{|c|}{ Mixture Proportions }} \\
\hline & & & & & & & & \\
\hline Material & Description & $\begin{array}{l}\text { Specific } \\
\text { Gravity } \\
\end{array}$ & Absorption & $\begin{array}{c}\text { Moisture } \\
\text { Content } \\
\end{array}$ & $\begin{array}{c}\text { Stock WTS } \\
\text { (lbs/batch) } \\
\end{array}$ & $\begin{array}{c}\text { Stock WTS } \\
\left(\mathrm{lbs} / \mathrm{yd}^{3}\right) \\
\end{array}$ & $\begin{array}{c}\text { SSD WTS } \\
\left(\mathrm{lbs} / \mathrm{yd}^{3}\right) \\
\end{array}$ & $\begin{array}{c}\text { ABS Volume } \\
\left(\mathrm{ft}^{3} / \mathrm{yd}^{3}\right)\end{array}$ \\
\hline Cement & Portland Type II/V & 3.15 & $\mathrm{~N} / \mathrm{A}$ & N/A & 50.0 & 1087 & 1087 & 5.532 \\
\hline Water & Municipal Water & 1.00 & N/A & $\mathrm{N} / \mathrm{A}$ & 14.8 & 322 & 327 & 5.239 \\
\hline Coarse Aggregates & Santa Margarita 1"x\#4 & 2.61 & $1.4 \%$ & $0.3 \%$ & 74.6 & 1622 & 1640 & 10.069 \\
\hline Recycled Concrete & $\mathrm{N} / \mathrm{A}$ & 2.47 & $4.9 \%$ & $0.0 \%$ & 0.0 & 0 & 0 & 0.000 \\
\hline Fine Aggregates & Sisquoc C33 Sand & 2.56 & $2.2 \%$ & $4.7 \%$ & 44.7 & 972 & 949 & 5.942 \\
\hline \multicolumn{2}{|c|}{ Air Content, Non-air-entrained (Entrapped) } & N/A & N/A & N/A & N/A & $\mathrm{N} / \mathrm{A}$ & N/A & 0.218 \\
\hline Total & & & & & 184 & 4003 & 4003 & 27.000 \\
\hline Superplasticizer & W.R. Grace ADVA 100 & & & & 82 & $\mathrm{ml} / \mathrm{batch}$ & 60.3 & $\mathrm{oz} / \mathrm{yd}^{3}$ \\
\hline
\end{tabular}

Temperature $\left({ }^{\circ} \mathrm{F}\right): \quad 73.0$

Slump (inches): 8.500

Unit Weight $\left(\mathrm{lbs} / \mathrm{ft}^{3}\right): \quad 148.3$

Air Content, Pressure Method (\%): N/A

Air Content, Volumetric Method (\%): $\quad 0.8 \%$

Batch Size $\left(\mathrm{ft}^{3}\right): \quad 1.242$

\begin{tabular}{|c|c|c|c|}
\hline \multicolumn{4}{|c|}{ Moisture Contents } \\
\hline & Sant. Marg. & N/A & Sand \\
\hline Pan (g.) & 634.8 & 0 & 635.6 \\
\hline Pan+Stock (g.) & 7422.4 & 1 & 6276.6 \\
\hline Pan+OD (g.) & 7401.8 & 1 & 6025.6 \\
\hline M.C. (\%) & $0.3 \%$ & $0.0 \%$ & $4.7 \%$ \\
\hline
\end{tabular}


Table A-18: Batch Record for R30-100

Mix Designation: R30-100

Date Cast: $\quad 8 / 20 / 2010$

Time Cast: $11: 30$

\begin{tabular}{|c|c|c|c|c|c|c|c|c|}
\hline & \multirow{2}{*}{\multicolumn{4}{|c|}{ Mixture Proportions }} \\
\hline & & & & & & & & \\
\hline Material & Description & $\begin{array}{l}\text { Specific } \\
\text { Gravity } \\
\end{array}$ & Absorption & $\begin{array}{c}\text { Moisture } \\
\text { Content } \\
\end{array}$ & $\begin{array}{l}\text { Stock WTS } \\
\text { (lbs/batch) }\end{array}$ & $\begin{array}{c}\text { Stock WTS } \\
\left(\mathrm{lbs} / \mathrm{yd}^{3}\right)\end{array}$ & $\begin{array}{c}\text { SSD WTS } \\
\left(\mathrm{lbs} / \mathrm{yd}^{3}\right)\end{array}$ & $\begin{array}{c}\text { ABS Volume } \\
\left(\mathrm{ft}^{3} / \mathrm{yd}^{3}\right)\end{array}$ \\
\hline Cement & Portland Type II/V & 3.15 & N/A & $\mathrm{N} / \mathrm{A}$ & 50.0 & 1087 & 1087 & 5.532 \\
\hline Water & Municipal Water & 1.00 & $\mathrm{~N} / \mathrm{A}$ & N/A & 16.2 & 352 & 326 & 5.222 \\
\hline Coarse Aggregates & $\mathrm{N} / \mathrm{A}$ & 2.61 & $1.4 \%$ & $0.0 \%$ & 0.0 & 0 & 0 & 0.000 \\
\hline Recycled Concrete & $\mathrm{R}$ & 2.47 & $4.9 \%$ & $1.6 \%$ & 69.1 & 1503 & 1552 & 10.070 \\
\hline Fine Aggregates & Sisquoc C33 Sand & 2.56 & $2.2 \%$ & $4.7 \%$ & 44.7 & 972 & 949 & 5.942 \\
\hline \multicolumn{2}{|c|}{ Air Content, Non-air-entrained (Entrapped) } & $\mathrm{N} / \mathrm{A}$ & $\mathrm{N} / \mathrm{A}$ & $\mathrm{N} / \mathrm{A}$ & $\mathrm{N} / \mathrm{A}$ & $\mathrm{N} / \mathrm{A}$ & N/A & 0.234 \\
\hline Total & & & & & 180 & 3914 & 3914 & 27.000 \\
\hline Superplasticizer & W.R. Grace ADVA 100 & & & & 104 & $\mathrm{ml} /$ batch & 76.5 & $\mathrm{oz} / \mathrm{yd}^{3}$ \\
\hline
\end{tabular}

Temperature $\left({ }^{\circ} \mathrm{F}\right): \quad 74.0$

Slump (inches): 8.000

Unit Weight $\left(\mathrm{lbs} / \mathrm{ft}^{3}\right): \quad 145.0$

Air Content, Pressure Method (\%): N/A

Air Content, Volumetric Method (\%): $\quad 0.9 \%$

Batch Size $\left(\mathrm{ft}^{3}\right): \quad 1.242$

\begin{tabular}{|c|c|c|c|}
\hline \multicolumn{4}{|c|}{ Moisture Contents } \\
\hline & N/A & R & Sand \\
\hline Pan (g.) & 0 & 635.1 & 635.6 \\
\hline Pan+Stock (g.) & 1 & 3806.2 & 6276.6 \\
\hline Pan+OD (g.) & 1 & 3757.2 & 6025.6 \\
\hline M.C. (\%) & $0.0 \%$ & $1.6 \%$ & $4.7 \%$ \\
\hline
\end{tabular}


Table A-19: Batch Record for RS30-100

Mix Designation: RS30-100

Date Cast: 9/25/2010

Time Cast: $\quad$ 11:00

\begin{tabular}{|c|c|c|c|c|c|c|c|c|}
\hline & \multirow{2}{*}{\multicolumn{4}{|c|}{ Mixture Proportions }} \\
\hline & & & & & & & & \\
\hline Material & Description & $\begin{array}{l}\text { Specific } \\
\text { Gravity } \\
\end{array}$ & Absorption & $\begin{array}{c}\text { Moisture } \\
\text { Content } \\
\end{array}$ & $\begin{array}{l}\text { Stock WTS } \\
\text { (lbs/batch) } \\
\end{array}$ & $\begin{array}{c}\text { Stock WTS } \\
\left(\mathrm{lbs} / \mathrm{yd}^{3}\right) \\
\end{array}$ & $\begin{array}{c}\text { SSD WTS } \\
\left(\mathrm{lbs} / \mathrm{yd}^{3}\right)\end{array}$ & $\begin{array}{c}\text { ABS Volume } \\
\left(\mathrm{ft}^{3} / \mathrm{yd}^{3}\right)\end{array}$ \\
\hline Cement & Portland Type II/V & 3.15 & N/A & N/A & 50.0 & 1082 & 1082 & 5.504 \\
\hline Water & Municipal Water & 1.00 & N/A & N/A & 11.7 & 253 & 324 & 5.197 \\
\hline Coarse Aggregates & $\mathrm{N} / \mathrm{A}$ & 2.61 & $1.4 \%$ & $0.0 \%$ & 0.0 & 0 & 0 & 0.000 \\
\hline Recycled Concrete & $\mathrm{RS}$ & 2.44 & $5.4 \%$ & $9.4 \%$ & 73.2 & 1584 & 1526 & 10.024 \\
\hline Fine Aggregates & Sisquoc C33 Sand & 2.56 & $2.2 \%$ & $3.7 \%$ & 44.3 & 958 & 945 & 5.915 \\
\hline \multicolumn{2}{|c|}{ Air Content, Non-air-entrained (Entrapped) } & $\mathrm{N} / \mathrm{A}$ & $\mathrm{N} / \mathrm{A}$ & $\mathrm{N} / \mathrm{A}$ & $\mathrm{N} / \mathrm{A}$ & $\mathrm{N} / \mathrm{A}$ & $\mathrm{N} / \mathrm{A}$ & 0.361 \\
\hline Total & & & & & 179 & 3877 & 3877 & 27.000 \\
\hline Superplasticizer & W.R. Grace ADVA 100 & & & & 115 & $\mathrm{ml} /$ batch & 84.1 & $\mathrm{oz} / \mathrm{yd}^{3}$ \\
\hline
\end{tabular}

Temperature $\left({ }^{\circ} \mathrm{F}\right): \quad 75.0$

Slump (inches): $\quad 9.000$

Unit Weight $\left(\mathrm{lbs} / \mathrm{ft}^{3}\right): \quad 143.6$

Air Content, Pressure Method (\%): N/A

Air Content, Volumetric Method (\%): $\quad 1.3 \%$

Batch Size $\left(\mathrm{ft}^{3}\right): \quad 1.248$

\begin{tabular}{|c|c|c|c|}
\hline \multicolumn{4}{|c|}{ Moisture Contents } \\
\hline & N/A & RS & Sand \\
\hline Pan (g.) & 0 & 970 & 557.5 \\
\hline Pan+Stock (g.) & 1 & 9878.9 & 6117 \\
\hline Pan+OD (g.) & 1 & 9115.2 & 5920.4 \\
\hline M.C. (\%) & $0.0 \%$ & $9.4 \%$ & $3.7 \%$ \\
\hline
\end{tabular}


Table A-20: Batch Record for RD30-100

Mix Designation: RD30-100

Date Cast: 9/25/2010

Time Cast: $\quad 11: 30$

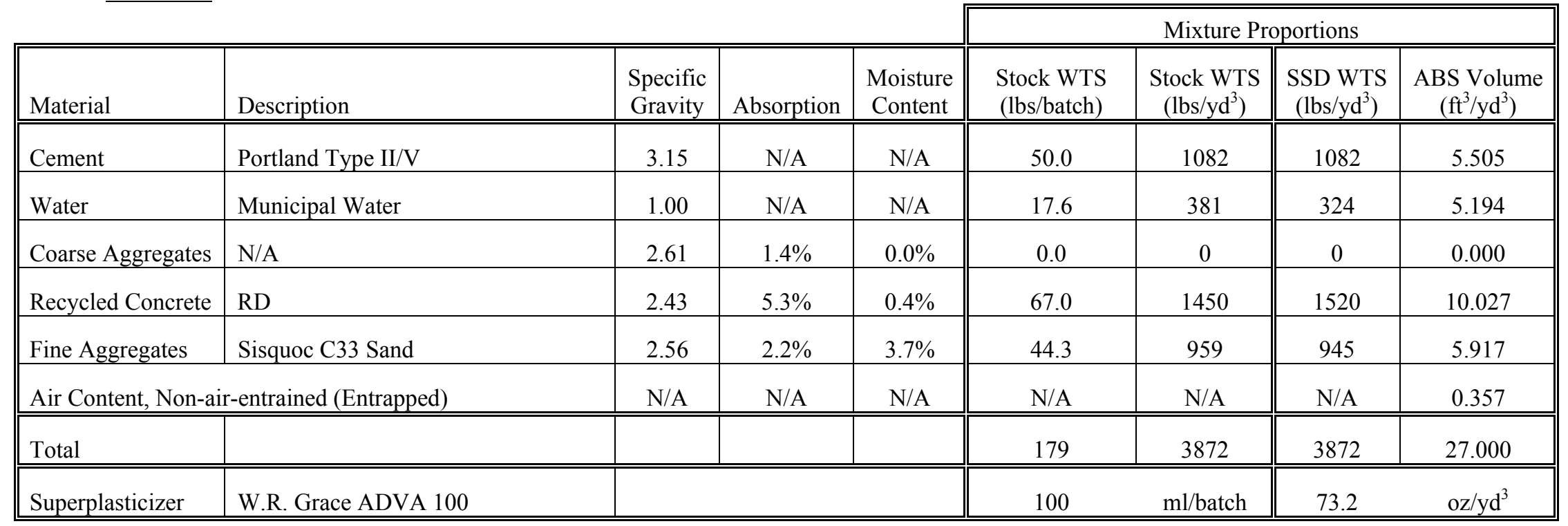

Temperature $\left({ }^{\circ} \mathrm{F}\right): \quad 75.0$

Slump (inches): $\quad 9.000$

Unit Weight $\left(\mathrm{lbs} / \mathrm{ft}^{3}\right): \quad 143.4$

Air Content, Pressure Method (\%): N/A

Air Content, Volumetric Method (\%): $\quad 1.3 \%$

Batch Size $\left(\mathrm{ft}^{3}\right): \quad 1.248$

\begin{tabular}{|c|c|c|c|}
\hline \multicolumn{4}{|c|}{ Moisture Contents } \\
\hline & N/A & RD & Sand \\
\hline Pan (g.) & 0 & 976 & 557.5 \\
\hline Pan+Stock (g.) & 1 & 5690.4 & 6117 \\
\hline Pan+OD (g.) & 1 & 5670.4 & 5920.4 \\
\hline M.C. (\%) & $0.0 \%$ & $0.4 \%$ & $3.7 \%$ \\
\hline
\end{tabular}




\section{Appendix B Prismatic Beam Records}


Table B-1: Prismatic Beam Specimen Data (N45-B)

Mix Designation:

N45-B
Date Concrete Mixed:

$8 / 27 / 2010$
Time Concrete:

$11: 30$

\begin{tabular}{|c|c|c|}
\hline & Sample A & Sample B \\
\hline Mass or Weight, M (lbs) & 15.701 & 15.757 \\
\hline Length, L (inches) & 16.06 & 16.00 \\
\hline Width, b (inches) & 3.05 & 3.05 \\
\hline Height, $\mathrm{h}$ (inches) & 3.76 & 3.74 \\
\hline
\end{tabular}

\begin{tabular}{||c|c|c||c|c||c|c||}
\hline Date & Time & $\begin{array}{c}\text { Age } \\
\text { (days) }\end{array}$ & $\begin{array}{c}\text { Natural } \\
\text { Frequency, } \\
\mathrm{n}(\mathrm{Hz})\end{array}$ & $\begin{array}{c}\text { Modulus of } \\
\text { Elasticity, } \\
\mathrm{E}_{\mathrm{d}}(\mathrm{psi})\end{array}$ & $\begin{array}{c}\text { Natural } \\
\text { Frequency, } \\
\mathrm{n}(\mathrm{Hz})\end{array}$ & $\begin{array}{c}\text { Modulus of } \\
\text { Elasticity, } \\
\mathrm{E}_{\mathrm{d}}(\mathrm{psi})\end{array}$ \\
\hline \hline $8 / 28 / 2010$ & $11: 35$ & 1.00 & 4060 & $3.75 \mathrm{E}+06$ & 4020 & $3.71 \mathrm{E}+06$ \\
\hline $8 / 30 / 2010$ & $14: 00$ & 3.10 & 4655 & $4.93 \mathrm{E}+06$ & 4640 & $4.94 \mathrm{E}+06$ \\
\hline $9 / 3 / 2010$ & $11: 10$ & 6.99 & 4825 & $5.30 \mathrm{E}+06$ & 4845 & $5.38 \mathrm{E}+06$ \\
\hline $9 / 10 / 2010$ & $10: 00$ & 13.94 & 4920 & $5.51 \mathrm{E}+06$ & 4950 & $5.62 \mathrm{E}+06$ \\
\hline $9 / 24 / 2010$ & $11: 30$ & 28.00 & 5040 & $5.78 \mathrm{E}+06$ & 5035 & $5.81 \mathrm{E}+06$ \\
\hline $10 / 22 / 2010$ & $17: 45$ & 56.26 & 5120 & $5.97 \mathrm{E}+06$ & 5130 & $6.03 \mathrm{E}+06$ \\
\hline $11 / 19 / 2010$ & $12: 45$ & 84.05 & 5165 & $6.07 \mathrm{E}+06$ & 5190 & $6.18 \mathrm{E}+06$ \\
\hline \hline
\end{tabular}




\section{Table B-2: Prismatic Beam Specimen Data (R45-25)}

Mix Designation:

$\mathrm{R} 45-25$
Date Concrete Mixed:

$9 / 3 / 2010$
Time Concrete:

$12: 30$

\begin{tabular}{|c|c|c|}
\hline & Sample A & Sample B \\
\hline Mass or Weight, M (lbs) & 15.635 & 15.876 \\
\hline Length, L (inches) & 16.13 & 16.06 \\
\hline Width, b (inches) & 3.06 & 3.09 \\
\hline Height, h (inches) & 3.82 & 3.84 \\
\hline
\end{tabular}

\begin{tabular}{||c|c|c||c|c||c|c||}
\hline Date & Time & $\begin{array}{c}\text { Age } \\
(\text { days })\end{array}$ & $\begin{array}{c}\text { Natural } \\
\text { Frequency, } \\
\mathrm{n}(\mathrm{Hz})\end{array}$ & $\begin{array}{c}\text { Modulus of } \\
\text { Elasticity, } \\
\mathrm{E}_{\mathrm{d}}(\mathrm{psi})\end{array}$ & $\begin{array}{c}\text { Natural } \\
\text { Frequency, } \\
\mathrm{n}(\mathrm{Hz})\end{array}$ & $\begin{array}{c}\text { Modulus of } \\
\text { Elasticity, } \\
\mathrm{E}_{\mathrm{d}}(\mathrm{psi})\end{array}$ \\
\hline \hline $9 / 4 / 2010$ & $13: 50$ & 1.06 & 3930 & $3.45 \mathrm{E}+06$ & 4030 & $3.62 \mathrm{E}+06$ \\
\hline $9 / 6 / 2010$ & $13: 30$ & 3.04 & 4480 & $4.48 \mathrm{E}+06$ & 4550 & $4.61 \mathrm{E}+06$ \\
\hline $9 / 10 / 2010$ & $10: 05$ & 6.90 & 4680 & $4.89 \mathrm{E}+06$ & 4735 & $4.99 \mathrm{E}+06$ \\
\hline $9 / 17 / 2010$ & $13: 55$ & 14.06 & 4800 & $5.14 \mathrm{E}+06$ & 4840 & $5.22 \mathrm{E}+06$ \\
\hline $10 / 1 / 2010$ & $9: 35$ & 27.88 & 4880 & $5.31 \mathrm{E}+06$ & 4940 & $5.44 \mathrm{E}+06$ \\
\hline $10 / 29 / 2010$ & $15: 55$ & 56.14 & 4980 & $5.53 \mathrm{E}+06$ & 5020 & $5.61 \mathrm{E}+06$ \\
\hline $11 / 26 / 2010$ & $17: 20$ & 84.20 & 5020 & $5.62 \mathrm{E}+06$ & 5090 & $5.77 \mathrm{E}+06$ \\
\hline
\end{tabular}




\section{Table B-3: Prismatic Beam Specimen Data (R45-50)}

Mix Designation:

$\mathrm{R} 45-50$
Date Concrete Mixed:

$7 / 9 / 2010$
Time Concrete:

$10: 45$

\begin{tabular}{|c|c|c|}
\hline & Sample A & Sample B \\
\hline Mass or Weight, M (lbs) & 15.222 & 15.152 \\
\hline Length, L (inches) & 16.06 & 16.03 \\
\hline Width, b (inches) & 3.04 & 3.04 \\
\hline Height, h (inches) & 3.77 & 3.76 \\
\hline
\end{tabular}

\begin{tabular}{||c|c|c||c|c||c|c||}
\hline \hline Date & Time & $\begin{array}{c}\text { Age } \\
\text { (days) }\end{array}$ & $\begin{array}{c}\text { Natural } \\
\text { Frequency, } \\
\mathrm{n}(\mathrm{Hz})\end{array}$ & $\begin{array}{c}\text { Modulus of } \\
\text { Elasticity, } \\
\mathrm{E}_{\mathrm{d}}(\mathrm{psi})\end{array}$ & $\begin{array}{c}\text { Natural } \\
\text { Frequency, } \\
\mathrm{n}(\mathrm{Hz})\end{array}$ & $\begin{array}{c}\text { Modulus of } \\
\text { Elasticity, } \\
\mathrm{E}_{\mathrm{d}}(\mathrm{psi})\end{array}$ \\
\hline \hline $7 / 12 / 2010$ & $12: 50$ & 3.09 & 4520 & $4.51 \mathrm{E}+06$ & 4600 & $4.66 \mathrm{E}+06$ \\
\hline $7 / 16 / 2010$ & $14: 00$ & 7.14 & 4700 & $4.88 \mathrm{E}+06$ & 4740 & $4.95 \mathrm{E}+06$ \\
\hline $7 / 23 / 2010$ & $13: 50$ & 14.13 & 4790 & $5.06 \mathrm{E}+06$ & 4820 & $5.12 \mathrm{E}+06$ \\
\hline $8 / 6 / 2010$ & $13: 00$ & 28.09 & 4860 & $5.21 \mathrm{E}+06$ & 4925 & $5.34 \mathrm{E}+06$ \\
\hline $10 / 1 / 2010$ & $10: 05$ & 83.97 & 4960 & $5.43 \mathrm{E}+06$ & 5015 & $5.54 \mathrm{E}+06$ \\
\hline
\end{tabular}


Table B-4: Prismatic Beam Specimen Data (R45-75)

Mix Designation:

R45-75
Date Concrete Mixed:

9/3/2010
Time Concrete:

13:00

\begin{tabular}{|c|c|c|}
\hline & Sample A & Sample B \\
\hline Mass or Weight, M (lbs) & 15.482 & 15.418 \\
\hline Length, L (inches) & 16.06 & 16.06 \\
\hline Width, $b$ (inches) & 3.05 & 3.05 \\
\hline Height, h (inches) & 3.78 & 3.77 \\
\hline
\end{tabular}

\begin{tabular}{||c|c|c||c|c||c|c||}
\hline Date & Time & $\begin{array}{c}\text { Age } \\
\text { (days) }\end{array}$ & $\begin{array}{c}\text { Natural } \\
\text { Frequency, } \\
\mathrm{n}(\mathrm{Hz})\end{array}$ & $\begin{array}{c}\text { Modulus of } \\
\text { Elasticity, } \\
\mathrm{E}_{\mathrm{d}}(\mathrm{psi})\end{array}$ & $\begin{array}{c}\text { Natural } \\
\text { Frequency, } \\
\mathrm{n}(\mathrm{Hz})\end{array}$ & $\begin{array}{c}\text { Modulus of } \\
\text { Elasticity, } \\
\mathrm{E}_{\mathrm{d}}(\mathrm{psi})\end{array}$ \\
\hline \hline $9 / 4 / 2010$ & $14: 15$ & 1.05 & 3935 & $3.46 \mathrm{E}+06$ & 4050 & $3.65 \mathrm{E}+06$ \\
\hline $9 / 6 / 2010$ & $13: 35$ & 3.02 & 4465 & $4.45 \mathrm{E}+06$ & 4500 & $4.51 \mathrm{E}+06$ \\
\hline $9 / 10 / 2010$ & $10: 15$ & 6.89 & 4640 & $4.81 \mathrm{E}+06$ & 4680 & $4.88 \mathrm{E}+06$ \\
\hline $9 / 17 / 2010$ & $13: 40$ & 14.03 & 4715 & $4.96 \mathrm{E}+06$ & 4760 & $5.05 \mathrm{E}+06$ \\
\hline $10 / 1 / 2010$ & $9: 40$ & 27.86 & 4790 & $5.12 \mathrm{E}+06$ & 4855 & $5.25 \mathrm{E}+06$ \\
\hline $10 / 29 / 2010$ & $16: 05$ & 56.13 & 4880 & $5.32 \mathrm{E}+06$ & 4915 & $5.38 \mathrm{E}+06$ \\
\hline $11 / 26 / 2010$ & $17: 30$ & 84.19 & 4940 & $5.45 \mathrm{E}+06$ & 4965 & $5.49 \mathrm{E}+06$ \\
\hline
\end{tabular}


Table B-5: Prismatic Beam Specimen Data (R45-100)

Mix Designation:

R45-100
Date Concrete Mixed:

$7 / 16 / 2010$
Time Concrete:

$11: 45$

\begin{tabular}{|c|c|c|}
\hline & Sample A & Sample B \\
\hline Mass or Weight, M (lbs) & 15.163 & 15.083 \\
\hline Length, L (inches) & 16.06 & 16.06 \\
\hline Width, b (inches) & 3.02 & 3.02 \\
\hline Height, $\mathrm{h}$ (inches) & 3.81 & 3.78 \\
\hline
\end{tabular}

\begin{tabular}{||c|c|c||c|c||c|c||}
\hline Date & Time & $\begin{array}{c}\text { Age } \\
\text { (days) }\end{array}$ & $\begin{array}{c}\text { Natural } \\
\text { Frequency, } \\
\mathrm{n}(\mathrm{Hz})\end{array}$ & $\begin{array}{c}\text { Modulus of } \\
\text { Elasticity, } \\
\mathrm{E}_{\mathrm{d}}(\mathrm{psi})\end{array}$ & $\begin{array}{c}\text { Natural } \\
\text { Frequency, } \\
\mathrm{n}(\mathrm{Hz})\end{array}$ & $\begin{array}{c}\text { Modulus of } \\
\text { Elasticity, } \\
\mathrm{E}_{\mathrm{d}}(\mathrm{psi})\end{array}$ \\
\hline \hline $7 / 17 / 2010$ & $13: 05$ & 1.09 & 4020 & $3.55 \mathrm{E}+06$ & 4105 & $3.70 \mathrm{E}+06$ \\
\hline $7 / 19 / 2010$ & $13: 15$ & 3.09 & 4450 & $4.36 \mathrm{E}+06$ & 4470 & $4.39 \mathrm{E}+06$ \\
\hline $7 / 23 / 2010$ & $13: 35$ & 7.11 & 4630 & $4.72 \mathrm{E}+06$ & 4645 & $4.74 \mathrm{E}+06$ \\
\hline $7 / 30 / 2010$ & $16: 20$ & 14.22 & 4675 & $4.81 \mathrm{E}+06$ & 4700 & $4.86 \mathrm{E}+06$ \\
\hline $8 / 13 / 2010$ & $8: 10$ & 27.88 & 4775 & $5.01 \mathrm{E}+06$ & 4760 & $4.98 \mathrm{E}+06$ \\
\hline $10 / 8 / 2010$ & $9: 15$ & 83.93 & 4875 & $5.23 \mathrm{E}+06$ & 4885 & $5.25 \mathrm{E}+06$ \\
\hline
\end{tabular}




\section{Table B-6: Prismatic Beam Specimen Data (RS45-50)}

Mix Designation:

RS45-50
Date Concrete Mixed:

9/26/2010
Time Concrete:

11:00

\begin{tabular}{|c|c|c|}
\hline & Sample A & Sample B \\
\hline Mass or Weight, M (lbs) & 15.374 & 15.526 \\
\hline Length, L (inches) & 16.00 & 16.00 \\
\hline Width, b (inches) & 3.04 & 3.03 \\
\hline Height, h (inches) & 3.75 & 3.76 \\
\hline
\end{tabular}

\begin{tabular}{||c|c|c||c|c||c|c||}
\hline Date & Time & $\begin{array}{c}\text { Age } \\
(\text { days })\end{array}$ & $\begin{array}{c}\text { Natural } \\
\text { Frequency, } \\
n(\mathrm{~Hz})\end{array}$ & $\begin{array}{c}\text { Modulus of } \\
\text { Elasticity, } \\
\mathrm{E}_{\mathrm{d}}(\mathrm{psi})\end{array}$ & $\begin{array}{c}\text { Natural } \\
\text { Frequency, } \\
\mathrm{n}(\mathrm{Hz})\end{array}$ & $\begin{array}{c}\text { Modulus of } \\
\text { Elasticity, } \\
\mathrm{E}_{\mathrm{d}}(\mathrm{psi})\end{array}$ \\
\hline \hline $9 / 27 / 2010$ & $8: 25$ & 0.89 & 3835 & $3.29 \mathrm{E}+06$ & 3855 & $3.36 \mathrm{E}+06$ \\
\hline $9 / 29 / 2010$ & $15: 35$ & 3.19 & 4440 & $4.41 \mathrm{E}+06$ & 4490 & $4.55 \mathrm{E}+06$ \\
\hline $10 / 3 / 2010$ & $11: 35$ & 7.02 & 4630 & $4.79 \mathrm{E}+06$ & 4685 & $4.96 \mathrm{E}+06$ \\
\hline $10 / 10 / 2010$ & $16: 25$ & 14.23 & 4730 & $5.00 \mathrm{E}+06$ & 4780 & $5.16 \mathrm{E}+06$ \\
\hline $10 / 24 / 2010$ & $12: 45$ & 28.07 & 4850 & $5.26 \mathrm{E}+06$ & 4910 & $5.44 \mathrm{E}+06$ \\
\hline $11 / 21 / 2010$ & $15: 00$ & 56.17 & 4970 & $5.52 \mathrm{E}+06$ & 4990 & $5.62 \mathrm{E}+06$ \\
\hline $12 / 19 / 2010$ & $17: 30$ & 84.27 & 5000 & $5.59 \mathrm{E}+06$ & 5040 & $5.73 \mathrm{E}+06$ \\
\hline
\end{tabular}




\section{Table B-7: Prismatic Beam Specimen Data (RS45-100)}

Mix Designation:

RS45-100
Date Concrete Mixed:

9/26/2010
Time Concrete:

$11: 30$

\begin{tabular}{|c|c|c|}
\hline & Sample A & Sample B \\
\hline Mass or Weight, M (lbs) & 15.512 & 15.174 \\
\hline Length, L (inches) & 16.06 & 16.00 \\
\hline Width, $b$ (inches) & 3.05 & 3.02 \\
\hline Height, h (inches) & 3.77 & 3.75 \\
\hline
\end{tabular}

\begin{tabular}{||c|c|c||c|c||c|c||}
\hline \hline Date & Time & $\begin{array}{c}\text { Age } \\
\text { (days) }\end{array}$ & $\begin{array}{c}\text { Natural } \\
\text { Frequency, } \\
\mathrm{n}(\mathrm{Hz})\end{array}$ & $\begin{array}{c}\text { Modulus of } \\
\text { Elasticity, } \\
\mathrm{E}_{\mathrm{d}}(\mathrm{psi})\end{array}$ & $\begin{array}{c}\text { Natural } \\
\text { Frequency, } \\
\mathrm{n}(\mathrm{Hz})\end{array}$ & $\begin{array}{c}\text { Modulus of } \\
\text { Elasticity, } \\
\mathrm{E}_{\mathrm{d}}(\mathrm{psi})\end{array}$ \\
\hline \hline $9 / 27 / 2010$ & $8: 35$ & 0.88 & 4055 & $3.70 \mathrm{E}+06$ & 3980 & $3.52 \mathrm{E}+06$ \\
\hline $9 / 29 / 2010$ & $15: 40$ & 3.17 & 4620 & $4.80 \mathrm{E}+06$ & 4530 & $4.56 \mathrm{E}+06$ \\
\hline $10 / 3 / 2010$ & $11: 45$ & 7.01 & 4760 & $5.09 \mathrm{E}+06$ & 4680 & $4.86 \mathrm{E}+06$ \\
\hline $10 / 10 / 2010$ & $16: 25$ & 14.20 & 4840 & $5.27 \mathrm{E}+06$ & 4760 & $5.03 \mathrm{E}+06$ \\
\hline $10 / 24 / 2010$ & $12: 50$ & 28.06 & 4935 & $5.47 \mathrm{E}+06$ & 4850 & $5.22 \mathrm{E}+06$ \\
\hline $11 / 21 / 2010$ & $15: 05$ & 56.15 & 5020 & $5.66 \mathrm{E}+06$ & 4945 & $5.43 \mathrm{E}+06$ \\
\hline $12 / 19 / 2010$ & $17: 30$ & 84.25 & 5040 & $5.71 \mathrm{E}+06$ & 4970 & $5.49 \mathrm{E}+06$ \\
\hline
\end{tabular}




\section{Table B-8: Prismatic Beam Specimen Data (RD45-50)}

Mix Designation:

RD45-50
Date Concrete Mixed:

9/26/2010
Time Concrete:

12:00

\begin{tabular}{|c|c|c|}
\hline & Sample A & Sample B \\
\hline Mass or Weight, M (lbs) & 15.424 & 15.286 \\
\hline Length, L (inches) & 16.00 & 16.00 \\
\hline Width, $b$ (inches) & 3.08 & 3.03 \\
\hline Height, h (inches) & 3.83 & 3.78 \\
\hline
\end{tabular}

\begin{tabular}{||c|c|c||c|c||c|c||}
\hline Date & Time & $\begin{array}{c}\text { Age } \\
\text { (days) }\end{array}$ & $\begin{array}{c}\text { Natural } \\
\text { Frequency, } \\
\mathrm{n}(\mathrm{Hz})\end{array}$ & $\begin{array}{c}\text { Modulus of } \\
\text { Elasticity, } \\
\mathrm{E}_{\mathrm{d}}(\mathrm{psi})\end{array}$ & $\begin{array}{c}\text { Natural } \\
\text { Frequency, } \\
\mathrm{n}(\mathrm{Hz})\end{array}$ & $\begin{array}{c}\text { Modulus of } \\
\text { Elasticity, } \\
\mathrm{E}_{\mathrm{d}}(\mathrm{psi})\end{array}$ \\
\hline \hline $9 / 27 / 2010$ & $8: 45$ & 0.86 & 3705 & $2.98 \mathrm{E}+06$ & 3685 & $3.00 \mathrm{E}+06$ \\
\hline $9 / 29 / 2010$ & $15: 45$ & 3.16 & 4400 & $4.21 \mathrm{E}+06$ & 4400 & $4.28 \mathrm{E}+06$ \\
\hline $10 / 3 / 2010$ & $11: 55$ & 7.00 & 4600 & $4.60 \mathrm{E}+06$ & 4605 & $4.69 \mathrm{E}+06$ \\
\hline $10 / 10 / 2010$ & $16: 35$ & 14.19 & 4715 & $4.83 \mathrm{E}+06$ & 4745 & $4.98 \mathrm{E}+06$ \\
\hline $10 / 24 / 2010$ & $13: 00$ & 28.04 & 4795 & $5.00 \mathrm{E}+06$ & 4835 & $5.17 \mathrm{E}+06$ \\
\hline $11 / 21 / 2010$ & $15: 10$ & 56.13 & 4910 & $5.24 \mathrm{E}+06$ & 4915 & $5.34 \mathrm{E}+06$ \\
\hline $12 / 19 / 2010$ & $17: 45$ & 84.24 & 4950 & $5.33 \mathrm{E}+06$ & 4980 & $5.49 \mathrm{E}+06$ \\
\hline
\end{tabular}


Table B-9: Prismatic Beam Specimen Data (RD45-100)

Mix Designation:

RD45-100
Date Concrete Mixed:

9/26/2010
Time Concrete:

$12: 30$

\begin{tabular}{|c|c|c|}
\hline & Sample A & Sample B \\
\hline Mass or Weight, M (lbs) & 14.953 & 14.921 \\
\hline Length, L (inches) & 16.00 & 16.06 \\
\hline Width, $b$ (inches) & 3.01 & 3.02 \\
\hline Height, h (inches) & 3.78 & 3.74 \\
\hline
\end{tabular}

\begin{tabular}{||c|c|c||c|c||c|c||}
\hline \hline Date & Time & $\begin{array}{c}\text { Age } \\
\text { (days) }\end{array}$ & $\begin{array}{c}\text { Natural } \\
\text { Frequency, } \\
\mathrm{n}(\mathrm{Hz})\end{array}$ & $\begin{array}{c}\text { Modulus of } \\
\text { Elasticity, } \\
\mathrm{E}_{\mathrm{d}}(\mathrm{psi})\end{array}$ & $\begin{array}{c}\text { Natural } \\
\text { Frequency, } \\
\mathrm{n}(\mathrm{Hz})\end{array}$ & $\begin{array}{c}\text { Modulus of } \\
\text { Elasticity, } \\
\mathrm{E}_{\mathrm{d}}(\mathrm{psi})\end{array}$ \\
\hline \hline $9 / 27 / 2010$ & $8: 10$ & 0.84 & 3680 & $2.95 \mathrm{E}+06$ & 3550 & $2.77 \mathrm{E}+06$ \\
\hline $9 / 29 / 2010$ & $18: 20$ & 3.26 & 4390 & $4.20 \mathrm{E}+06$ & 4250 & $3.97 \mathrm{E}+06$ \\
\hline $10 / 3 / 2010$ & $12: 15$ & 7.01 & 4570 & $4.55 \mathrm{E}+06$ & 4440 & $4.33 \mathrm{E}+06$ \\
\hline $10 / 10 / 2010$ & $16: 40$ & 14.19 & 4685 & $4.78 \mathrm{E}+06$ & 4555 & $4.56 \mathrm{E}+06$ \\
\hline $10 / 24 / 2010$ & $13: 05$ & 28.05 & 4760 & $4.94 \mathrm{E}+06$ & 4670 & $4.79 \mathrm{E}+06$ \\
\hline $11 / 21 / 2010$ & $15: 15$ & 56.14 & 4860 & $5.15 \mathrm{E}+06$ & 4745 & $4.95 \mathrm{E}+06$ \\
\hline $12 / 19 / 2010$ & $17: 30$ & 84.23 & 4900 & $5.23 \mathrm{E}+06$ & 4775 & $5.01 \mathrm{E}+06$ \\
\hline
\end{tabular}


Table B-10: Prismatic Beam Specimen Data (RLD45-100)

Mix Designation:

RLD45-100
Date Concrete Mixed:

9/26/2010
Time Concrete:

13:00

\begin{tabular}{|c|c|c|}
\hline & Sample A & Sample B \\
\hline Mass or Weight, M (lbs) & 15.041 & 15.145 \\
\hline Length, L (inches) & 16.06 & 16.00 \\
\hline Width, b (inches) & 3.02 & 3.02 \\
\hline Height, $\mathrm{h}$ (inches) & 3.77 & 3.76 \\
\hline
\end{tabular}

\begin{tabular}{||c|c|c||c|c||c|c||}
\hline Date & Time & $\begin{array}{c}\text { Age } \\
\text { (days) }\end{array}$ & $\begin{array}{c}\text { Natural } \\
\text { Frequency, } \\
\mathrm{n}(\mathrm{Hz})\end{array}$ & $\begin{array}{c}\text { Modulus of } \\
\text { Elasticity, } \\
\mathrm{E}_{\mathrm{d}}(\mathrm{psi})\end{array}$ & $\begin{array}{c}\text { Natural } \\
\text { Frequency, } \\
\mathrm{n}(\mathrm{Hz})\end{array}$ & $\begin{array}{c}\text { Modulus of } \\
\text { Elasticity, } \\
\mathrm{E}_{\mathrm{d}}(\mathrm{psi})\end{array}$ \\
\hline \hline $9 / 27 / 2010$ & $8: 20$ & 0.85 & 3580 & $2.82 \mathrm{E}+06$ & 3585 & $2.84 \mathrm{E}+06$ \\
\hline $9 / 29 / 2010$ & $18: 25$ & 3.27 & 4335 & $4.14 \mathrm{E}+06$ & 4335 & $4.15 \mathrm{E}+06$ \\
\hline $10 / 3 / 2010$ & $12: 25$ & 7.02 & 4485 & $4.43 \mathrm{E}+06$ & 4505 & $4.48 \mathrm{E}+06$ \\
\hline $10 / 10 / 2010$ & $16: 45$ & 14.20 & 4615 & $4.69 \mathrm{E}+06$ & 4610 & $4.69 \mathrm{E}+06$ \\
\hline $10 / 24 / 2010$ & $13: 15$ & 28.05 & 4700 & $4.86 \mathrm{E}+06$ & 4715 & $4.91 \mathrm{E}+06$ \\
\hline $11 / 21 / 2010$ & $15: 30$ & 56.15 & 4780 & $5.03 \mathrm{E}+06$ & 4790 & $5.07 \mathrm{E}+06$ \\
\hline $12 / 19 / 2010$ & $17: 45$ & 84.24 & 4830 & $5.14 \mathrm{E}+06$ & 4840 & $5.17 \mathrm{E}+06$ \\
\hline
\end{tabular}




\section{Table B-11: Prismatic Beam Specimen Data (RHD45-100)}

$\begin{array}{lll}\text { Mix Designation: } & \text { Date Concrete Mixed: } & \text { Time Concrete: } \\ \text { RHD45-100 } & 10 / 1 / 2010 & 8: 45\end{array}$

\begin{tabular}{|c|c|c|}
\hline & Sample A & Sample B \\
\hline Mass or Weight, M (lbs) & 15.176 & 15.251 \\
\hline Length, L (inches) & 16.06 & 16.06 \\
\hline Width, $b$ (inches) & 3.05 & 3.04 \\
\hline Height, $\mathrm{h}$ (inches) & 3.75 & 3.81 \\
\hline
\end{tabular}

\begin{tabular}{||c|c|c||c|c||c|c||}
\hline Date & Time & $\begin{array}{c}\text { Age } \\
\text { (days) }\end{array}$ & $\begin{array}{c}\text { Natural } \\
\text { Frequency, } \\
\mathrm{n}(\mathrm{Hz})\end{array}$ & $\begin{array}{c}\text { Modulus of } \\
\text { Elasticity, } \\
\mathrm{E}_{\mathrm{d}}(\mathrm{psi})\end{array}$ & $\begin{array}{c}\text { Natural } \\
\text { Frequency, } \\
\mathrm{n}(\mathrm{Hz})\end{array}$ & $\begin{array}{c}\text { Modulus of } \\
\text { Elasticity, } \\
\mathrm{E}_{\mathrm{d}}(\mathrm{psi})\end{array}$ \\
\hline \hline $10 / 2 / 2010$ & $11: 20$ & 1.11 & 3810 & $3.20 \mathrm{E}+06$ & 3790 & $3.15 \mathrm{E}+06$ \\
\hline $10 / 4 / 2010$ & $12: 25$ & 3.15 & 4300 & $4.08 \mathrm{E}+06$ & 4295 & $4.04 \mathrm{E}+06$ \\
\hline $10 / 8 / 2010$ & $9: 05$ & 7.01 & 4500 & $4.47 \mathrm{E}+06$ & 4520 & $4.48 \mathrm{E}+06$ \\
\hline $10 / 15 / 2010$ & $17: 40$ & 14.37 & 4660 & $4.79 \mathrm{E}+06$ & 4620 & $4.68 \mathrm{E}+06$ \\
\hline $10 / 29 / 2010$ & $15: 45$ & 28.29 & 4740 & $4.96 \mathrm{E}+06$ & 4745 & $4.94 \mathrm{E}+06$ \\
\hline $11 / 26 / 2010$ & $17: 20$ & 56.36 & 4850 & $5.19 \mathrm{E}+06$ & 4850 & $5.16 \mathrm{E}+06$ \\
\hline $1 / 4 / 2011$ & $16: 15$ & 95.31 & 4900 & $5.30 \mathrm{E}+06$ & 4890 & $5.24 \mathrm{E}+06$ \\
\hline
\end{tabular}


Table B-12: Prismatic Beam Specimen Data (N60)

Mix Designation:

N60
Date Concrete Mixed:

7/30/2010
Time Concrete:

12:45

\begin{tabular}{|c|c|c|}
\hline & Sample A & Sample B \\
\hline Mass or Weight, M (lbs) & 15.215 & 15.123 \\
\hline Length, L (inches) & 16.00 & 16.00 \\
\hline Width, b (inches) & 3.01 & 3.05 \\
\hline Height, $\mathrm{h}$ (inches) & 3.78 & 3.77 \\
\hline
\end{tabular}

\begin{tabular}{||c|c|c||c|c||c|c||}
\hline Date & Time & $\begin{array}{c}\text { Age } \\
\text { (days) }\end{array}$ & $\begin{array}{c}\text { Natural } \\
\text { Frequency, } \\
\mathrm{n}(\mathrm{Hz})\end{array}$ & $\begin{array}{c}\text { Modulus of } \\
\text { Elasticity, } \\
\mathrm{E}_{\mathrm{d}}(\mathrm{psi})\end{array}$ & $\begin{array}{c}\text { Natural } \\
\text { Frequency, } \\
\mathrm{n}(\mathrm{Hz})\end{array}$ & $\begin{array}{c}\text { Modulus of } \\
\text { Elasticity, } \\
\mathrm{E}_{\mathrm{d}}(\mathrm{psi})\end{array}$ \\
\hline \hline $7 / 31 / 2010$ & $13: 58$ & 1.05 & 3750 & $3.12 \mathrm{E}+06$ & 3760 & $3.09 \mathrm{E}+06$ \\
\hline $8 / 2 / 2010$ & $12: 45$ & 3.00 & 4315 & $4.13 \mathrm{E}+06$ & 4320 & $4.07 \mathrm{E}+06$ \\
\hline $8 / 6 / 2010$ & $12: 55$ & 7.01 & 4580 & $4.65 \mathrm{E}+06$ & 4570 & $4.56 \mathrm{E}+06$ \\
\hline $8 / 13 / 2010$ & $8: 30$ & 13.82 & 4670 & $4.84 \mathrm{E}+06$ & 4685 & $4.79 \mathrm{E}+06$ \\
\hline $8 / 27 / 2010$ & $10: 20$ & 27.90 & 4780 & $5.07 \mathrm{E}+06$ & 4815 & $5.06 \mathrm{E}+06$ \\
\hline $9 / 24 / 2010$ & $13: 05$ & 56.01 & 4860 & $5.24 \mathrm{E}+06$ & 4890 & $5.22 \mathrm{E}+06$ \\
\hline $10 / 22 / 2010$ & $17: 45$ & 84.21 & 4920 & $5.37 \mathrm{E}+06$ & 4920 & $5.28 \mathrm{E}+06$ \\
\hline \hline
\end{tabular}




\section{Table B-13: Prismatic Beam Specimen Data (R60-100)}

Mix Designation:

R60-100
Date Concrete Mixed:

$8 / 6 / 2010$
Time Concrete:

$10: 30$

\begin{tabular}{|c|c|c|}
\hline & Sample A & Sample B \\
\hline Mass or Weight, M (lbs) & 14.939 & 15.078 \\
\hline Length, L (inches) & 16.00 & 16.00 \\
\hline Width, $b$ (inches) & 3.01 & 3.01 \\
\hline Height, h (inches) & 3.77 & 3.78 \\
\hline
\end{tabular}

\begin{tabular}{||c|c|c||c|c||c|c||}
\hline Date & Time & $\begin{array}{c}\text { Age } \\
\text { (days) }\end{array}$ & $\begin{array}{c}\text { Natural } \\
\text { Frequency, } \\
\mathrm{n}(\mathrm{Hz})\end{array}$ & $\begin{array}{c}\text { Modulus of } \\
\text { Elasticity, } \\
\mathrm{E}_{\mathrm{d}}(\mathrm{psi})\end{array}$ & $\begin{array}{c}\text { Natural } \\
\text { Frequency, } \\
\mathrm{n}(\mathrm{Hz})\end{array}$ & $\begin{array}{c}\text { Modulus of } \\
\text { Elasticity, } \\
\mathrm{E}_{\mathrm{d}}(\mathrm{psi})\end{array}$ \\
\hline \hline $8 / 7 / 2010$ & $11: 50$ & 1.06 & 3625 & $2.87 \mathrm{E}+06$ & 3640 & $2.91 \mathrm{E}+06$ \\
\hline $8 / 9 / 2010$ & $13: 25$ & 3.13 & 4225 & $3.90 \mathrm{E}+06$ & 4240 & $3.95 \mathrm{E}+06$ \\
\hline $8 / 13 / 2010$ & $8: 50$ & 6.93 & 4440 & $4.31 \mathrm{E}+06$ & 4435 & $4.32 \mathrm{E}+06$ \\
\hline $8 / 20 / 2010$ & $19: 30$ & 14.38 & 4550 & $4.52 \mathrm{E}+06$ & 4535 & $4.52 \mathrm{E}+06$ \\
\hline $9 / 3 / 2010$ & $16: 55$ & 28.27 & 4605 & $4.63 \mathrm{E}+06$ & 4630 & $4.71 \mathrm{E}+06$ \\
\hline $10 / 1 / 2010$ & $9: 55$ & 55.98 & 4700 & $4.82 \mathrm{E}+06$ & 4680 & $4.81 \mathrm{E}+06$ \\
\hline $10 / 29 / 2010$ & $16: 15$ & 84.24 & 4710 & $4.84 \mathrm{E}+06$ & 4690 & $4.83 \mathrm{E}+06$ \\
\hline
\end{tabular}




\section{Table B-14: Prismatic Beam Specimen Data (RS60-100)}

Mix Designation:

RS60-100
Date Concrete Mixed:

$9 / 25 / 2010$
Time Concrete:

12:00

\begin{tabular}{|c|c|c|}
\hline & Sample A & Sample B \\
\hline Mass or Weight, M (lbs) & 15.315 & 15.002 \\
\hline Length, L (inches) & 16.06 & 16.06 \\
\hline Width, $b$ (inches) & 3.05 & 3.04 \\
\hline Height, $\mathrm{h}$ (inches) & 3.75 & 3.78 \\
\hline
\end{tabular}

\begin{tabular}{||c|c|c||c|c||c|c||}
\hline Date & Time & $\begin{array}{c}\text { Age } \\
\text { (days) }\end{array}$ & $\begin{array}{c}\text { Natural } \\
\text { Frequency, } \\
\mathrm{n}(\mathrm{Hz})\end{array}$ & $\begin{array}{c}\text { Modulus of } \\
\text { Elasticity, } \\
\mathrm{E}_{\mathrm{d}}(\mathrm{psi})\end{array}$ & $\begin{array}{c}\text { Natural } \\
\text { Frequency, } \\
\mathrm{n}(\mathrm{Hz})\end{array}$ & $\begin{array}{c}\text { Modulus of } \\
\text { Elasticity, } \\
\mathrm{E}_{\mathrm{d}}(\mathrm{psi})\end{array}$ \\
\hline \hline $9 / 26 / 2010$ & $15: 45$ & 1.16 & 3910 & $3.41 \mathrm{E}+06$ & 3800 & $3.14 \mathrm{E}+06$ \\
\hline $9 / 28 / 2010$ & $10: 00$ & 2.92 & 4315 & $4.16 \mathrm{E}+06$ & 4230 & $3.89 \mathrm{E}+06$ \\
\hline $10 / 2 / 2010$ & $11: 00$ & 6.96 & 4540 & $4.60 \mathrm{E}+06$ & 4465 & $4.33 \mathrm{E}+06$ \\
\hline $10 / 9 / 2010$ & $12: 00$ & 14.00 & 4660 & $4.85 \mathrm{E}+06$ & 4560 & $4.52 \mathrm{E}+06$ \\
\hline $10 / 23 / 2010$ & $14: 15$ & 28.09 & 4745 & $5.03 \mathrm{E}+06$ & 4700 & $4.80 \mathrm{E}+06$ \\
\hline $11 / 20 / 2010$ & $13: 40$ & 56.07 & 4830 & $5.21 \mathrm{E}+06$ & 4740 & $4.88 \mathrm{E}+06$ \\
\hline $12 / 18 / 2010$ & $17: 20$ & 84.22 & 4885 & $5.33 \mathrm{E}+06$ & 4795 & $4.99 \mathrm{E}+06$ \\
\hline
\end{tabular}


Table B-15: Prismatic Beam Specimen Data (RD60-100)

Mix Designation:

RD60-100
Date Concrete Mixed:

9/25/2010
Time Concrete:

$12: 30$

\begin{tabular}{|c|c|c|}
\hline & Sample A & Sample B \\
\hline Mass or Weight, M (lbs) & 14.874 & 15.090 \\
\hline Length, L (inches) & 16.00 & 16.00 \\
\hline Width, $b$ (inches) & 3.02 & 3.03 \\
\hline Height, h (inches) & 3.76 & 3.77 \\
\hline
\end{tabular}

\begin{tabular}{||c|c|c||c|c||c|c||}
\hline \hline Date & Time & $\begin{array}{c}\text { Age } \\
\text { (days) }\end{array}$ & $\begin{array}{c}\text { Natural } \\
\text { Frequency, } \\
\mathrm{n}(\mathrm{Hz})\end{array}$ & $\begin{array}{c}\text { Modulus of } \\
\text { Elasticity, } \\
\mathrm{E}_{\mathrm{d}}(\mathrm{psi})\end{array}$ & $\begin{array}{c}\text { Natural } \\
\text { Frequency, } \\
\mathrm{n}(\mathrm{Hz})\end{array}$ & $\begin{array}{c}\text { Modulus of } \\
\text { Elasticity, } \\
\mathrm{E}_{\mathrm{d}}(\mathrm{psi})\end{array}$ \\
\hline \hline $9 / 26 / 2010$ & $16: 00$ & 1.15 & 3495 & $2.66 \mathrm{E}+06$ & 3545 & $2.75 \mathrm{E}+06$ \\
\hline $9 / 28 / 2010$ & $10: 10$ & 2.90 & 3975 & $3.44 \mathrm{E}+06$ & 4015 & $3.53 \mathrm{E}+06$ \\
\hline $10 / 2 / 2010$ & $11: 05$ & 6.94 & 4210 & $3.85 \mathrm{E}+06$ & 4240 & $3.94 \mathrm{E}+06$ \\
\hline $10 / 9 / 2010$ & $12: 10$ & 13.99 & 4365 & $4.14 \mathrm{E}+06$ & 4385 & $4.21 \mathrm{E}+06$ \\
\hline $10 / 23 / 2010$ & $14: 20$ & 28.08 & 4490 & $4.38 \mathrm{E}+06$ & 4535 & $4.51 \mathrm{E}+06$ \\
\hline $11 / 20 / 2010$ & $13: 45$ & 56.05 & 4560 & $4.52 \mathrm{E}+06$ & 4610 & $4.66 \mathrm{E}+06$ \\
\hline $12 / 18 / 2010$ & $17: 30$ & 84.21 & 4615 & $4.63 \mathrm{E}+06$ & 4665 & $4.77 \mathrm{E}+06$ \\
\hline
\end{tabular}


Table B-16: Prismatic Beam Specimen Data (N30)

Mix Designation:

N30
Date Concrete Mixed:

$8 / 20 / 2010$
Time Concrete:

11:00

\begin{tabular}{|c|c|c|}
\hline & Sample A & Sample B \\
\hline Mass or Weight, M (lbs) & 16.256 & 15.737 \\
\hline Length, L (inches) & 16.06 & 16.06 \\
\hline Width, $b$ (inches) & 3.03 & 3.01 \\
\hline Height, h (inches) & 3.87 & 3.78 \\
\hline
\end{tabular}

\begin{tabular}{||c|c|c||c|c||c|c||}
\hline Date & Time & $\begin{array}{c}\text { Age } \\
\text { (days) }\end{array}$ & $\begin{array}{c}\text { Natural } \\
\text { Frequency, } \\
\mathrm{n}(\mathrm{Hz})\end{array}$ & $\begin{array}{c}\text { Modulus of } \\
\text { Elasticity, } \\
\mathrm{E}_{\mathrm{d}}(\mathrm{psi})\end{array}$ & $\begin{array}{c}\text { Natural } \\
\text { Frequency, } \\
\mathrm{n}(\mathrm{Hz})\end{array}$ & $\begin{array}{c}\text { Modulus of } \\
\text { Elasticity, } \\
\mathrm{E}_{\mathrm{d}}(\mathrm{psi})\end{array}$ \\
\hline \hline $8 / 21 / 2010$ & $14: 40$ & 1.15 & 4490 & $4.65 \mathrm{E}+06$ & 4515 & $4.69 \mathrm{E}+06$ \\
\hline $8 / 23 / 2010$ & $12: 45$ & 3.07 & 4800 & $5.32 \mathrm{E}+06$ & 4790 & $5.27 \mathrm{E}+06$ \\
\hline $8 / 27 / 2010$ & $10: 35$ & 6.98 & 4880 & $5.50 \mathrm{E}+06$ & 4885 & $5.48 \mathrm{E}+06$ \\
\hline $9 / 3 / 2010$ & $11: 00$ & 14.00 & 4960 & $5.68 \mathrm{E}+06$ & 4950 & $5.63 \mathrm{E}+06$ \\
\hline $9 / 17 / 2010$ & $13: 20$ & 28.10 & 4980 & $5.72 \mathrm{E}+06$ & 5000 & $5.75 \mathrm{E}+06$ \\
\hline $10 / 15 / 2010$ & $17: 40$ & 56.28 & 5040 & $5.86 \mathrm{E}+06$ & 5030 & $5.82 \mathrm{E}+06$ \\
\hline $11 / 12 / 2010$ & $17: 50$ & 84.28 & 5070 & $5.93 \mathrm{E}+06$ & 5060 & $5.88 \mathrm{E}+06$ \\
\hline
\end{tabular}




\section{Table B-17: Prismatic Beam Specimen Data (R30-100)}

Mix Designation:

R30-100
Date Concrete Mixed:

$8 / 20 / 2010$
Time Concrete:

$11: 30$

\begin{tabular}{|c|c|c|}
\hline & Sample A & Sample B \\
\hline Mass or Weight, M (lbs) & 15.568 & 15.670 \\
\hline Length, L (inches) & 16.00 & 16.00 \\
\hline Width, $b$ (inches) & 3.02 & 3.01 \\
\hline Height, h (inches) & 3.84 & 3.85 \\
\hline
\end{tabular}

\begin{tabular}{||c|c|c||c|c||c|c||}
\hline Date & Time & $\begin{array}{c}\text { Age } \\
\text { (days) }\end{array}$ & $\begin{array}{c}\text { Natural } \\
\text { Frequency, } \\
\mathrm{n}(\mathrm{Hz})\end{array}$ & $\begin{array}{c}\text { Modulus of } \\
\text { Elasticity, } \\
\mathrm{E}_{\mathrm{d}}(\mathrm{psi})\end{array}$ & $\begin{array}{c}\text { Natural } \\
\text { Frequency, } \\
\mathrm{n}(\mathrm{Hz})\end{array}$ & $\begin{array}{c}\text { Modulus of } \\
\text { Elasticity, } \\
\mathrm{E}_{\mathrm{d}}(\mathrm{psi})\end{array}$ \\
\hline \hline $8 / 21 / 2010$ & $14: 45$ & 1.14 & 4420 & $4.36 \mathrm{E}+06$ & 4425 & $4.39 \mathrm{E}+06$ \\
\hline $8 / 23 / 2010$ & $12: 40$ & 3.05 & 4700 & $4.93 \mathrm{E}+06$ & 4725 & $5.01 \mathrm{E}+06$ \\
\hline $8 / 27 / 2010$ & $10: 40$ & 6.97 & 4780 & $5.10 \mathrm{E}+06$ & 4805 & $5.18 \mathrm{E}+06$ \\
\hline $9 / 3 / 2010$ & $10: 55$ & 13.98 & 4860 & $5.27 \mathrm{E}+06$ & 4870 & $5.32 \mathrm{E}+06$ \\
\hline $9 / 17 / 2010$ & $13: 30$ & 28.08 & 4900 & $5.36 \mathrm{E}+06$ & 4925 & $5.44 \mathrm{E}+06$ \\
\hline $10 / 15 / 2010$ & $17: 45$ & 56.26 & 4955 & $5.48 \mathrm{E}+06$ & 4980 & $5.57 \mathrm{E}+06$ \\
\hline $11 / 12 / 2010$ & $17: 50$ & 84.26 & 4980 & $5.53 \mathrm{E}+06$ & 5025 & $5.67 \mathrm{E}+06$ \\
\hline
\end{tabular}




\section{Table B-18: Prismatic Beam Specimen Data (RS30-100)}

Mix Designation:

RS30-100
Date Concrete Mixed:

$9 / 25 / 2010$
Time Concrete:

11:00

\begin{tabular}{|c|c|c|}
\hline & Sample A & Sample B \\
\hline Mass or Weight, M (lbs) & 15.499 & 15.446 \\
\hline Length, L (inches) & 16.06 & 16.00 \\
\hline Width, $b$ (inches) & 3.01 & 3.01 \\
\hline Height, h (inches) & 3.78 & 3.79 \\
\hline
\end{tabular}

\begin{tabular}{||c|c|c||c|c||c|c||}
\hline Date & Time & $\begin{array}{c}\text { Age } \\
\text { (days) }\end{array}$ & $\begin{array}{c}\text { Natural } \\
\text { Frequency, } \\
\mathrm{n}(\mathrm{Hz})\end{array}$ & $\begin{array}{c}\text { Modulus of } \\
\text { Elasticity, } \\
\mathrm{E}_{\mathrm{d}}(\mathrm{psi})\end{array}$ & $\begin{array}{c}\text { Natural } \\
\text { Frequency, } \\
\mathrm{n}(\mathrm{Hz})\end{array}$ & $\begin{array}{c}\text { Modulus of } \\
\text { Elasticity, } \\
\mathrm{E}_{\mathrm{d}}(\mathrm{psi})\end{array}$ \\
\hline \hline $9 / 26 / 2010$ & $16: 15$ & 1.22 & 4605 & $4.81 \mathrm{E}+06$ & 4630 & $4.82 \mathrm{E}+06$ \\
\hline $9 / 28 / 2010$ & $9: 50$ & 2.95 & 4810 & $5.24 \mathrm{E}+06$ & 4810 & $5.20 \mathrm{E}+06$ \\
\hline $10 / 2 / 2010$ & $10: 45$ & 6.99 & 4930 & $5.51 \mathrm{E}+06$ & 4925 & $5.45 \mathrm{E}+06$ \\
\hline $10 / 9 / 2010$ & $11: 50$ & 14.03 & 4990 & $5.64 \mathrm{E}+06$ & 4985 & $5.58 \mathrm{E}+06$ \\
\hline $10 / 23 / 2010$ & $13: 50$ & 28.12 & 5040 & $5.76 \mathrm{E}+06$ & 5040 & $5.71 \mathrm{E}+06$ \\
\hline $11 / 20 / 2010$ & $13: 30$ & 56.10 & 5090 & $5.87 \mathrm{E}+06$ & 5100 & $5.84 \mathrm{E}+06$ \\
\hline $12 / 18 / 2010$ & $17: 10$ & 84.26 & 5120 & $5.94 \mathrm{E}+06$ & 5135 & $5.92 \mathrm{E}+06$ \\
\hline
\end{tabular}




\section{Table B-19: Prismatic Beam Specimen Data (RD30-100)}

Mix Designation:

RD30-100
Date Concrete Mixed:

$9 / 25 / 2010$
Time Concrete:

$11: 30$

\begin{tabular}{|c|c|c|}
\hline & Sample A & Sample B \\
\hline Mass or Weight, M (lbs) & 15.099 & 15.296 \\
\hline Length, L (inches) & 16.06 & 16.00 \\
\hline Width, b (inches) & 3.02 & 3.04 \\
\hline Height, h (inches) & 3.74 & 3.73 \\
\hline
\end{tabular}

\begin{tabular}{||c|c|c||c|c||c|c||}
\hline Date & Time & $\begin{array}{c}\text { Age } \\
(\text { days })\end{array}$ & $\begin{array}{c}\text { Natural } \\
\text { Frequency, } \\
\mathrm{n}(\mathrm{Hz})\end{array}$ & $\begin{array}{c}\text { Modulus of } \\
\text { Elasticity, } \\
\mathrm{E}_{\mathrm{d}}(\mathrm{psi})\end{array}$ & $\begin{array}{c}\text { Natural } \\
\text { Frequency, } \\
\mathrm{n}(\mathrm{Hz})\end{array}$ & $\begin{array}{c}\text { Modulus of } \\
\text { Elasticity, } \\
\mathrm{E}_{\mathrm{d}}(\mathrm{psi})\end{array}$ \\
\hline \hline $9 / 26 / 2010$ & $16: 30$ & 1.21 & 4140 & $3.82 \mathrm{E}+06$ & 4190 & $3.92 \mathrm{E}+06$ \\
\hline $9 / 28 / 2010$ & $9: 50$ & 2.93 & 4470 & $4.45 \mathrm{E}+06$ & 4500 & $4.52 \mathrm{E}+06$ \\
\hline $10 / 2 / 2010$ & $10: 45$ & 6.97 & 4595 & $4.70 \mathrm{E}+06$ & 4640 & $4.81 \mathrm{E}+06$ \\
\hline $10 / 9 / 2010$ & $11: 55$ & 14.02 & 4685 & $4.89 \mathrm{E}+06$ & 4720 & $4.98 \mathrm{E}+06$ \\
\hline $10 / 23 / 2010$ & $13: 55$ & 28.10 & 4755 & $5.03 \mathrm{E}+06$ & 4765 & $5.07 \mathrm{E}+06$ \\
\hline $11 / 20 / 2010$ & $13: 35$ & 56.09 & 4810 & $5.15 \mathrm{E}+06$ & 4850 & $5.25 \mathrm{E}+06$ \\
\hline $12 / 18 / 2010$ & $17: 20$ & 84.24 & 4860 & $5.26 \mathrm{E}+06$ & 4880 & $5.32 \mathrm{E}+06$ \\
\hline
\end{tabular}




\section{Appendix C Shrinkage Curves}






Figure C-1: Shrinkage Specimen Data w/ Prediction Curves (N45-A)

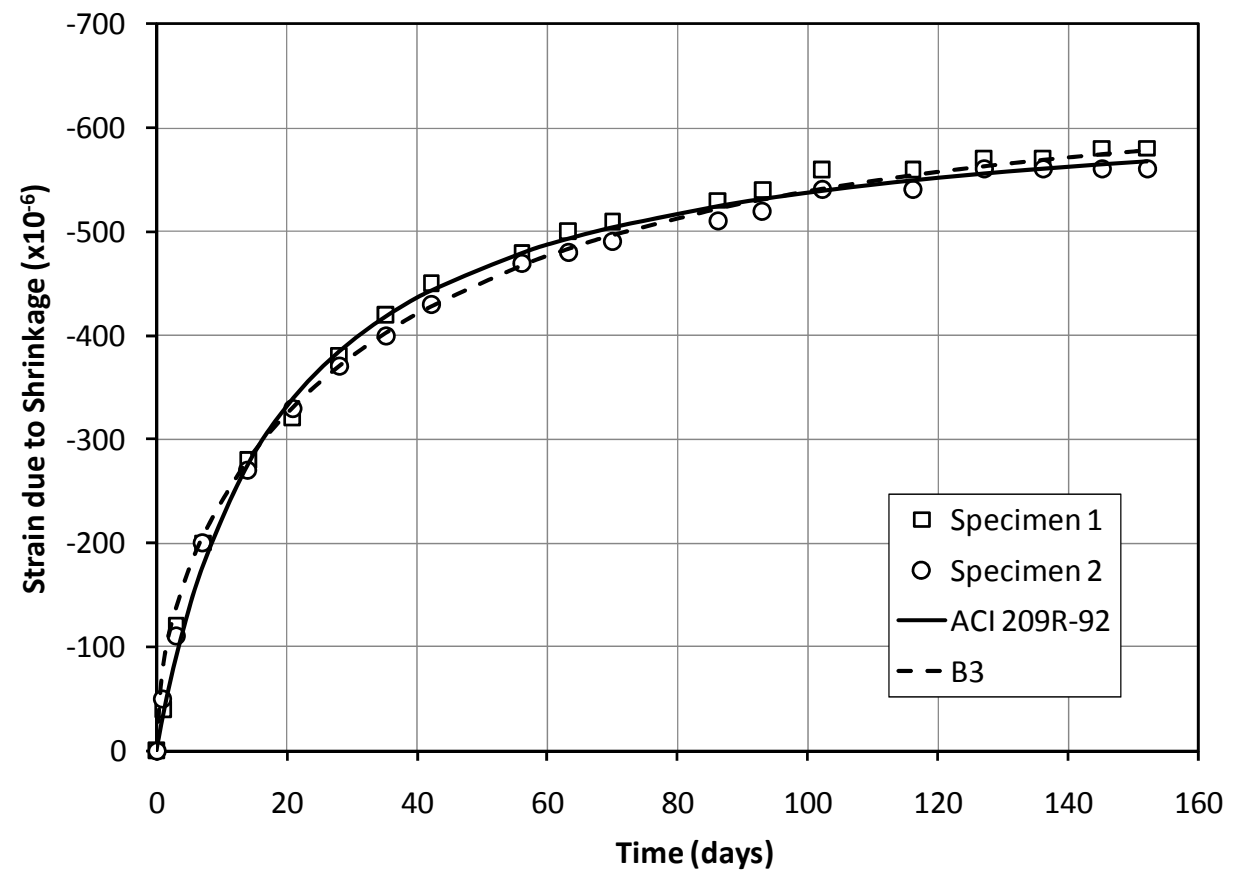

Figure C-2: Shrinkage Specimen Data w/ Prediction Curves (N45-B) 


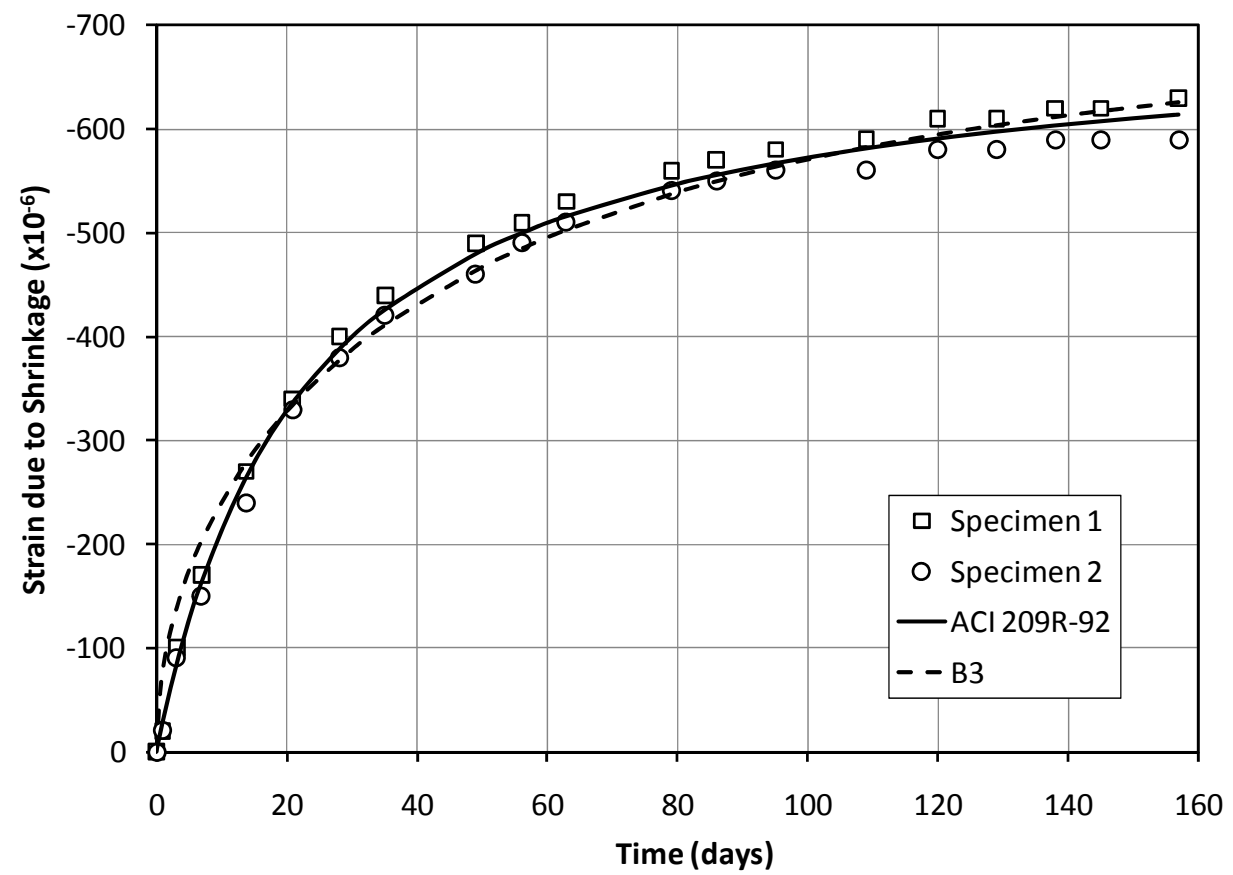

Figure C-3: Shrinkage Specimen Data w/ Prediction Curves (R45-25)

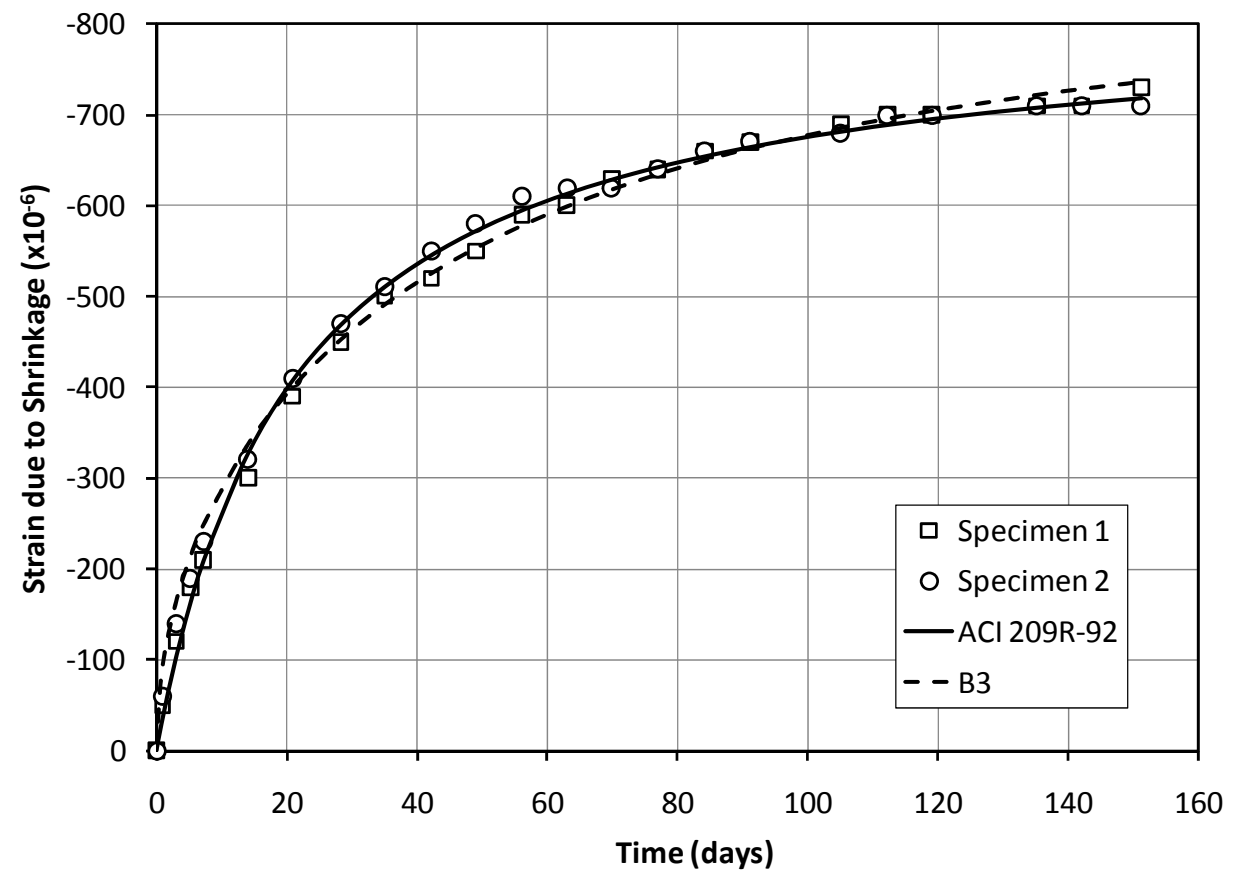

Figure C-4: Shrinkage Specimen Data w/ Prediction Curves (R45-50) 


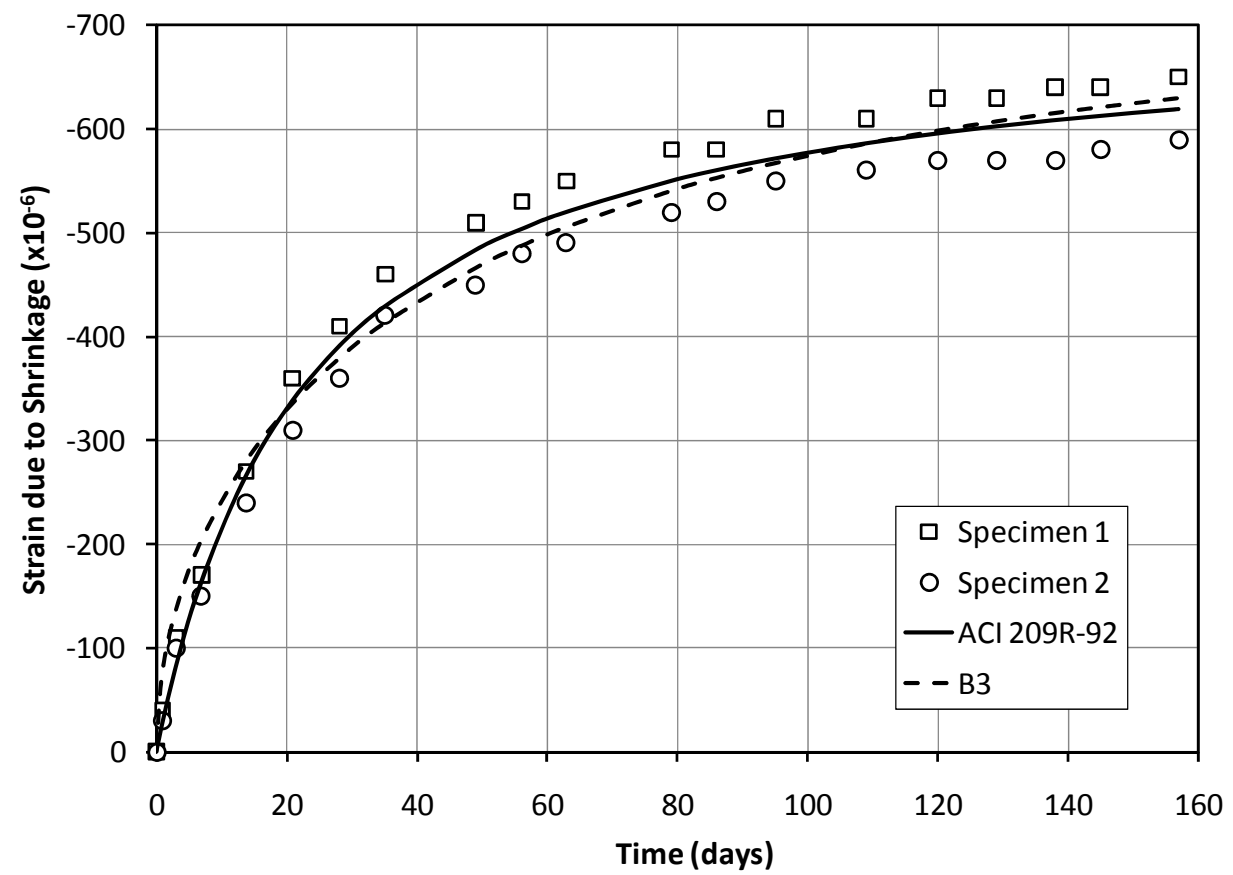

Figure C-5: Shrinkage Specimen Data w/ Prediction Curves (R45-75)

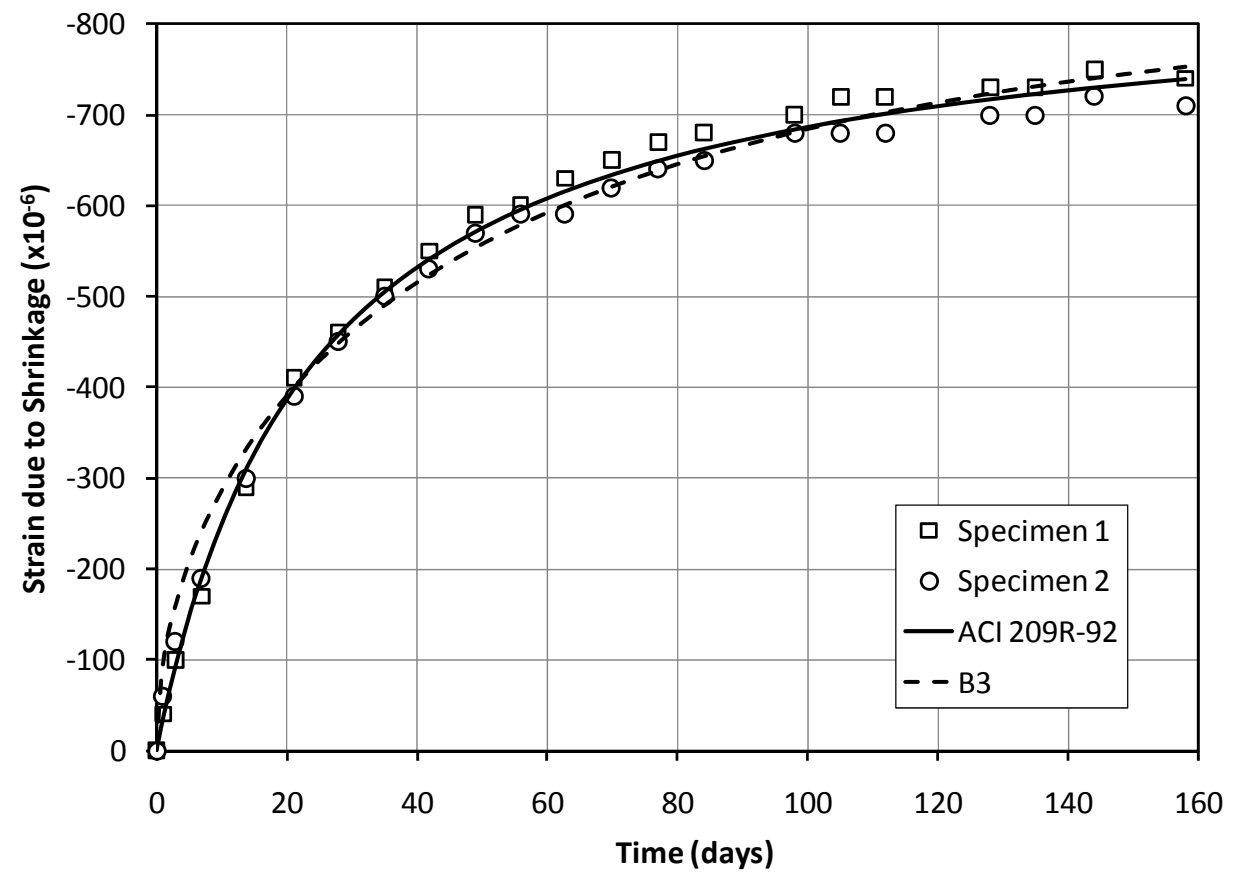

Figure C-6: Shrinkage Specimen Data w/ Prediction Curves (R45-100) 


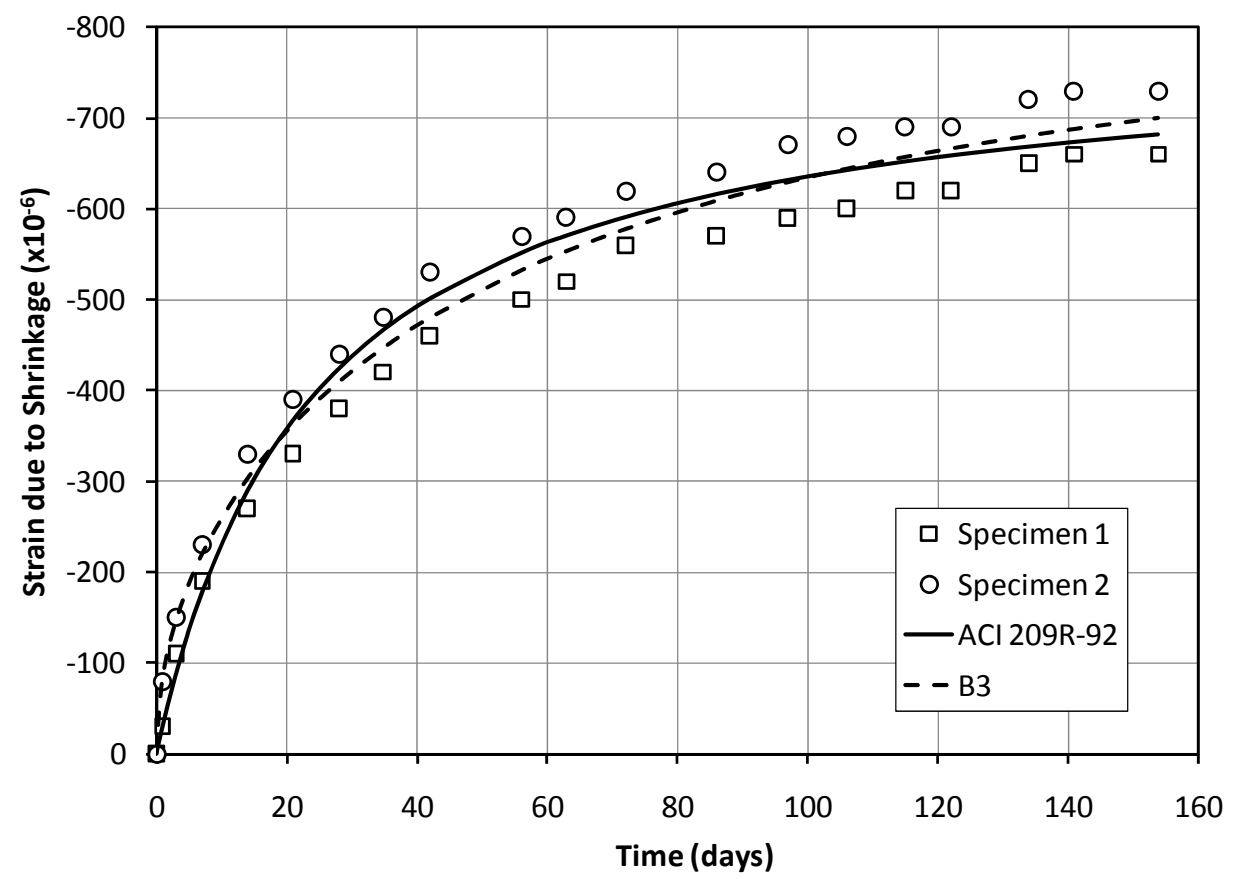

Figure C-7: Shrinkage Specimen Data w/ Prediction Curves (RS45-50)

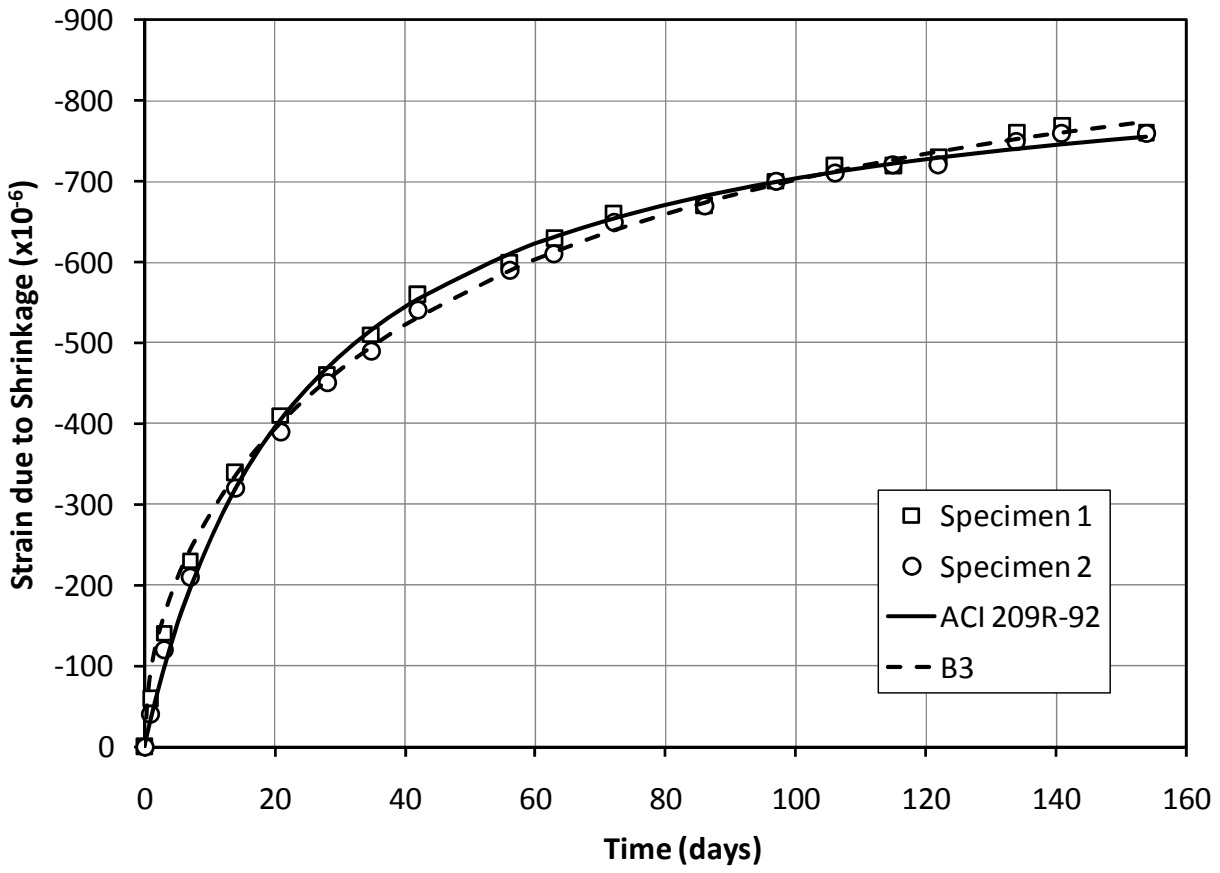

Figure C-8: Shrinkage Specimen Data w/ Prediction Curves (RS45-100) 


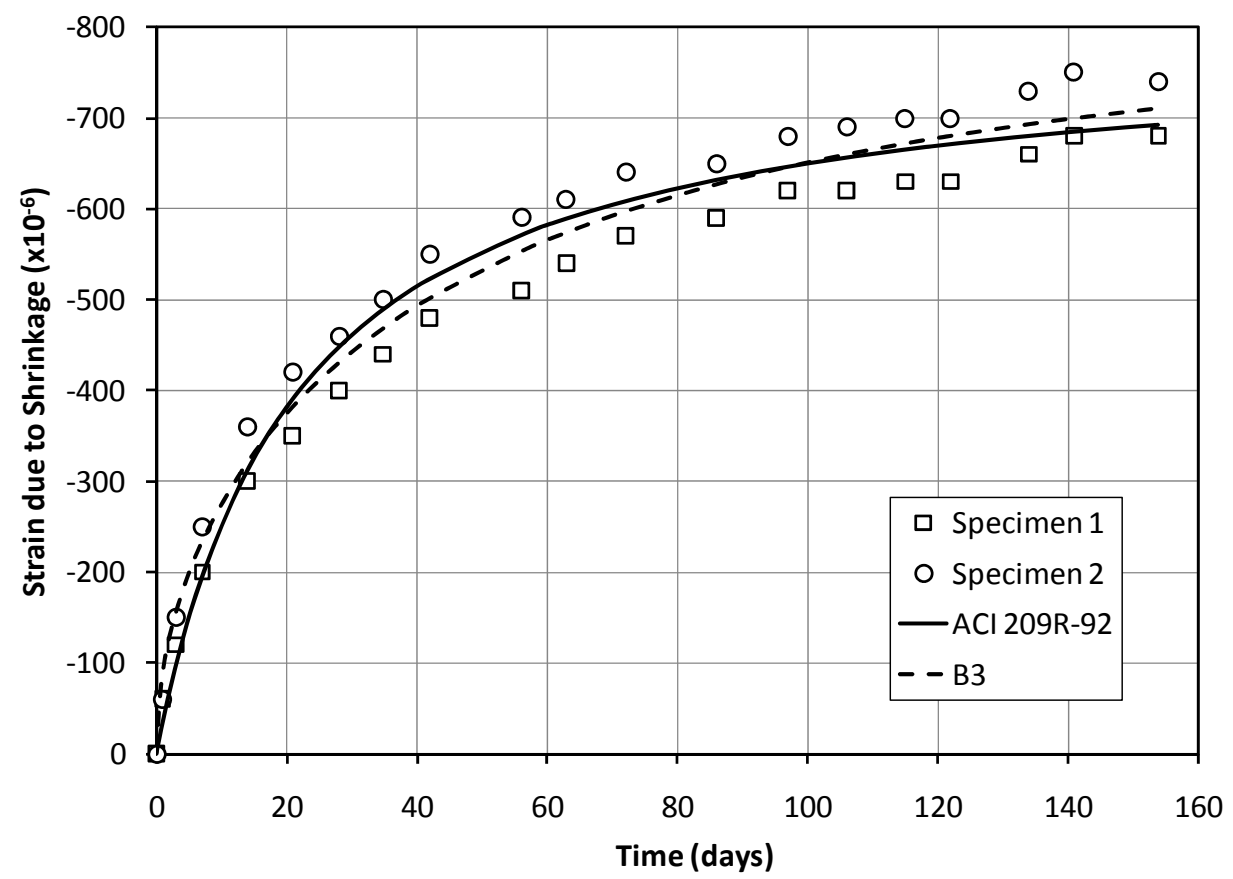

Figure C-9: Shrinkage Specimen Data w/ Prediction Curves (RD45-50)

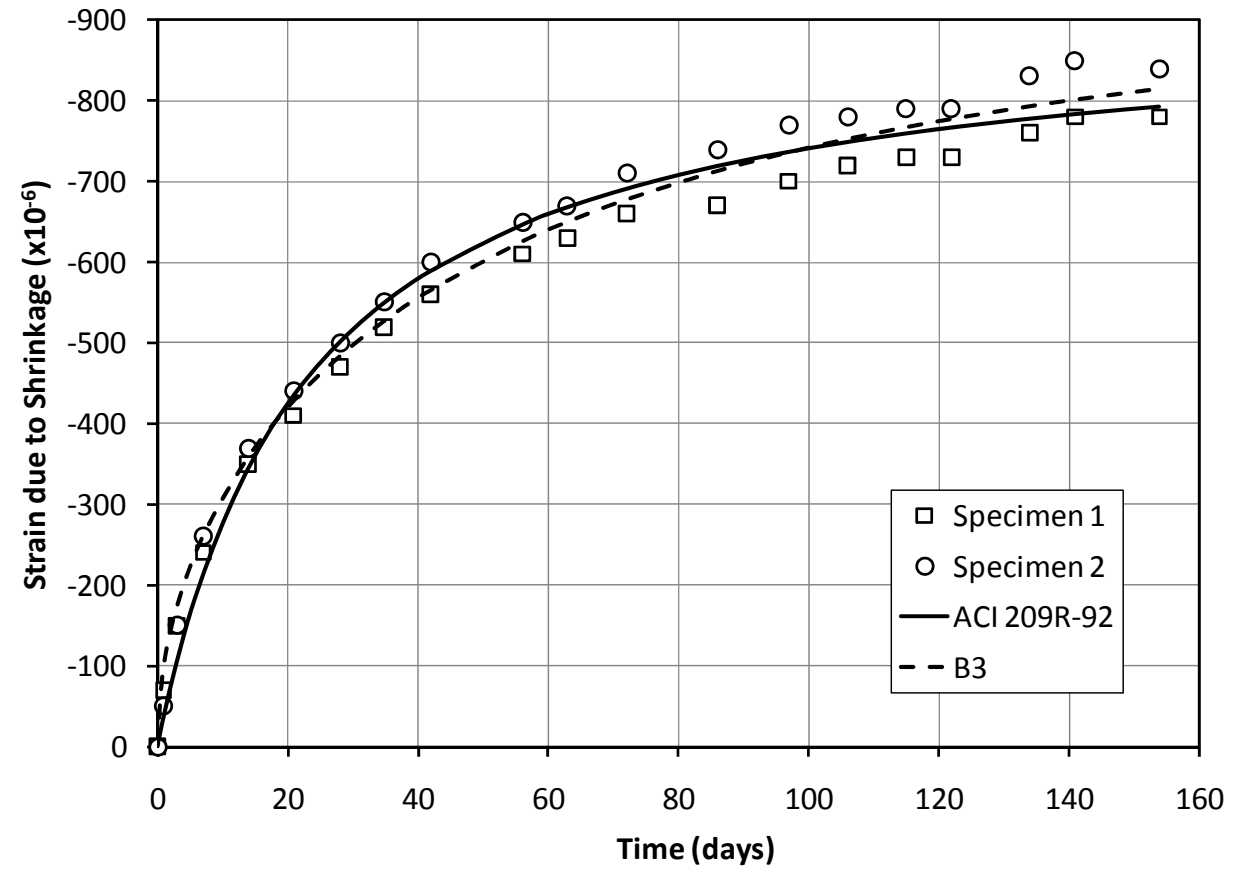

Figure C-10: Shrinkage Specimen Data w/ Prediction Curves (RD45-100) 


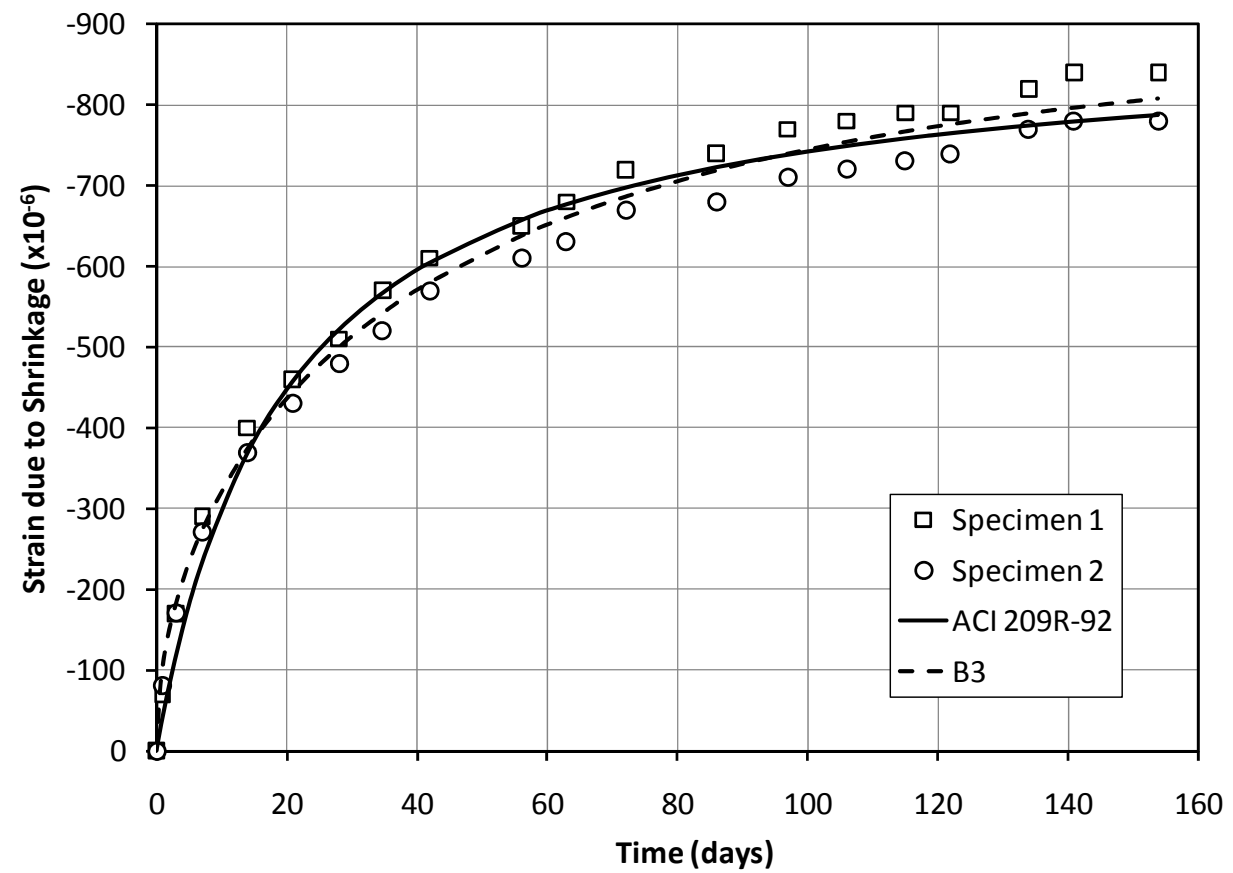

Figure C-11: Shrinkage Specimen Data w/ Prediction Curves (RLD45-50)

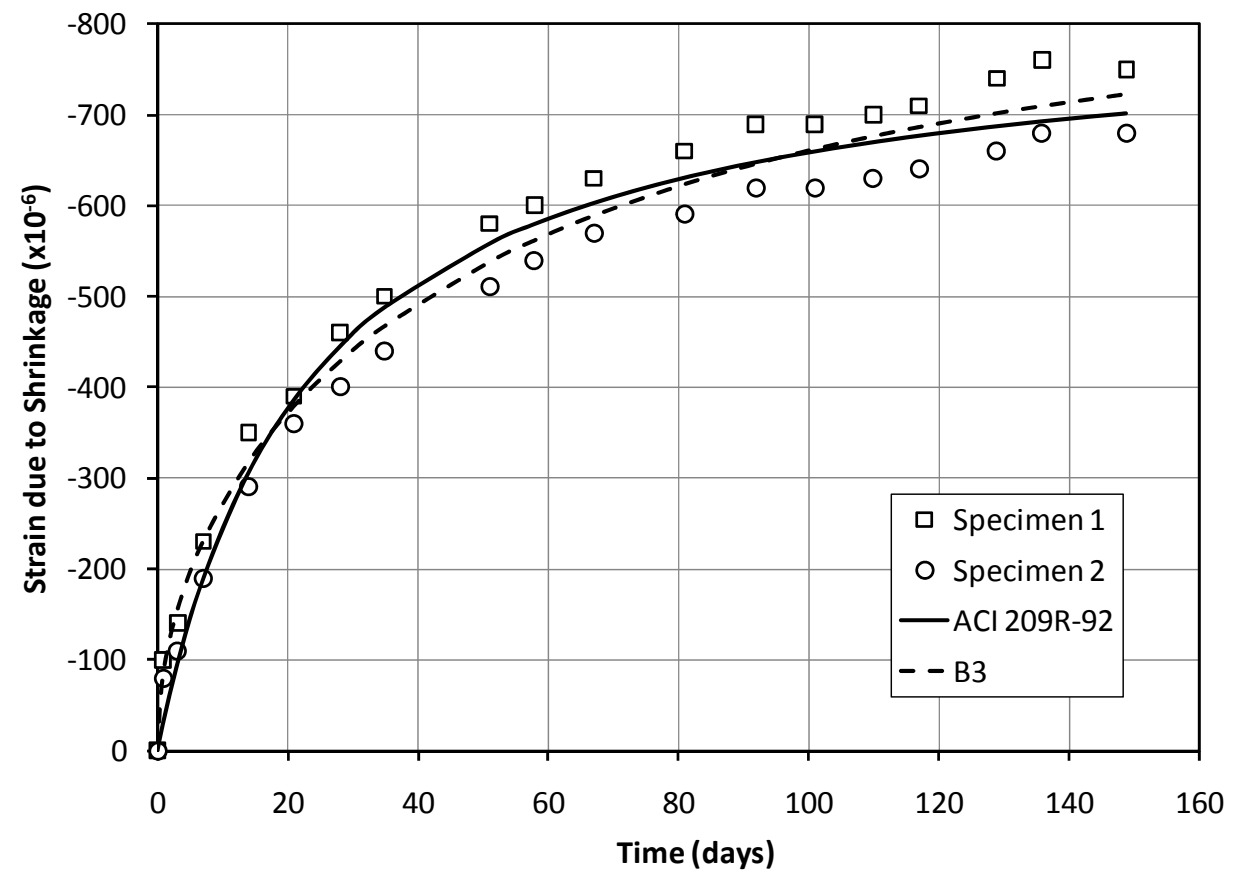

Figure C-12: Shrinkage Specimen Data w/ Prediction Curves (RHD45-100) 


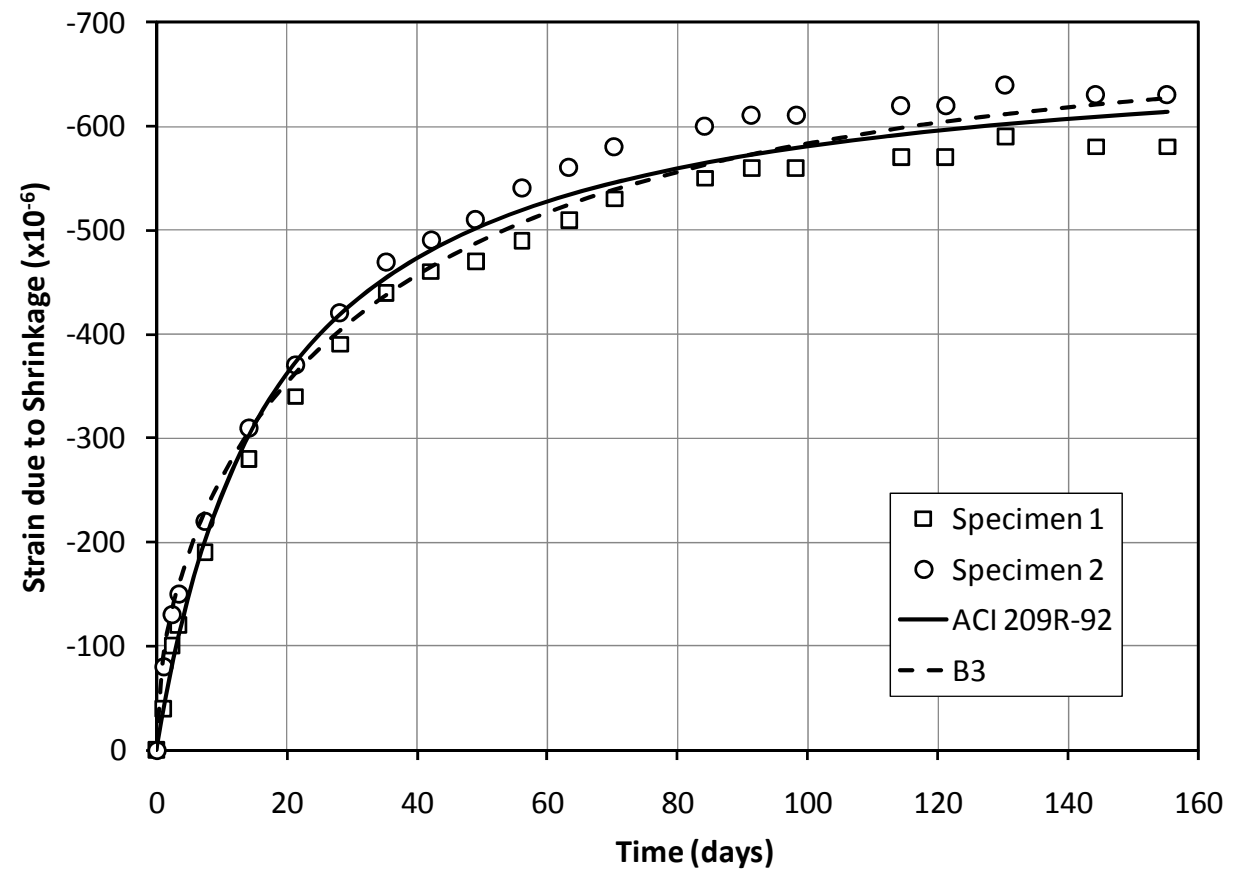

Figure C-13: Shrinkage Specimen Data w/ Prediction Curves (N60)

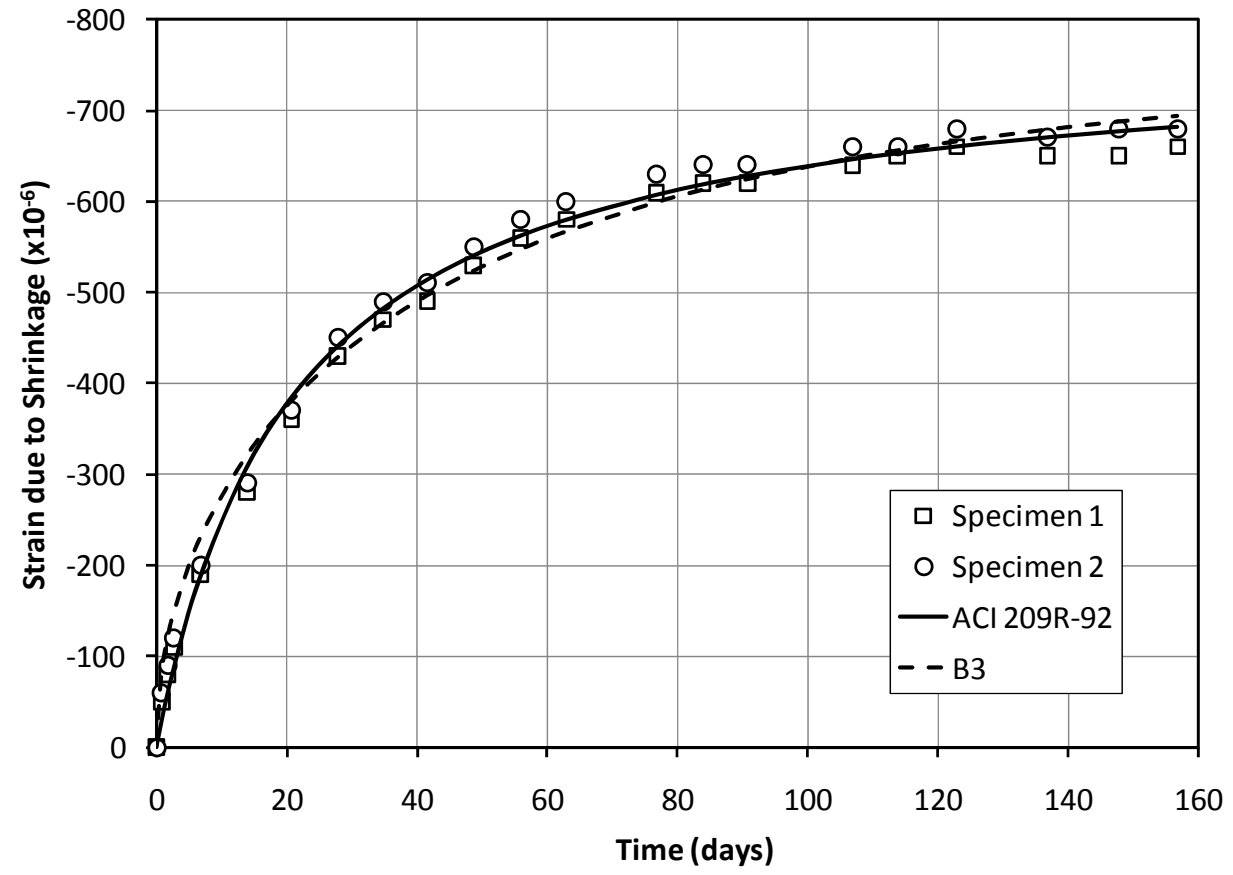

Figure C-14: Shrinkage Specimen Data w/ Prediction Curves (R60-100) 


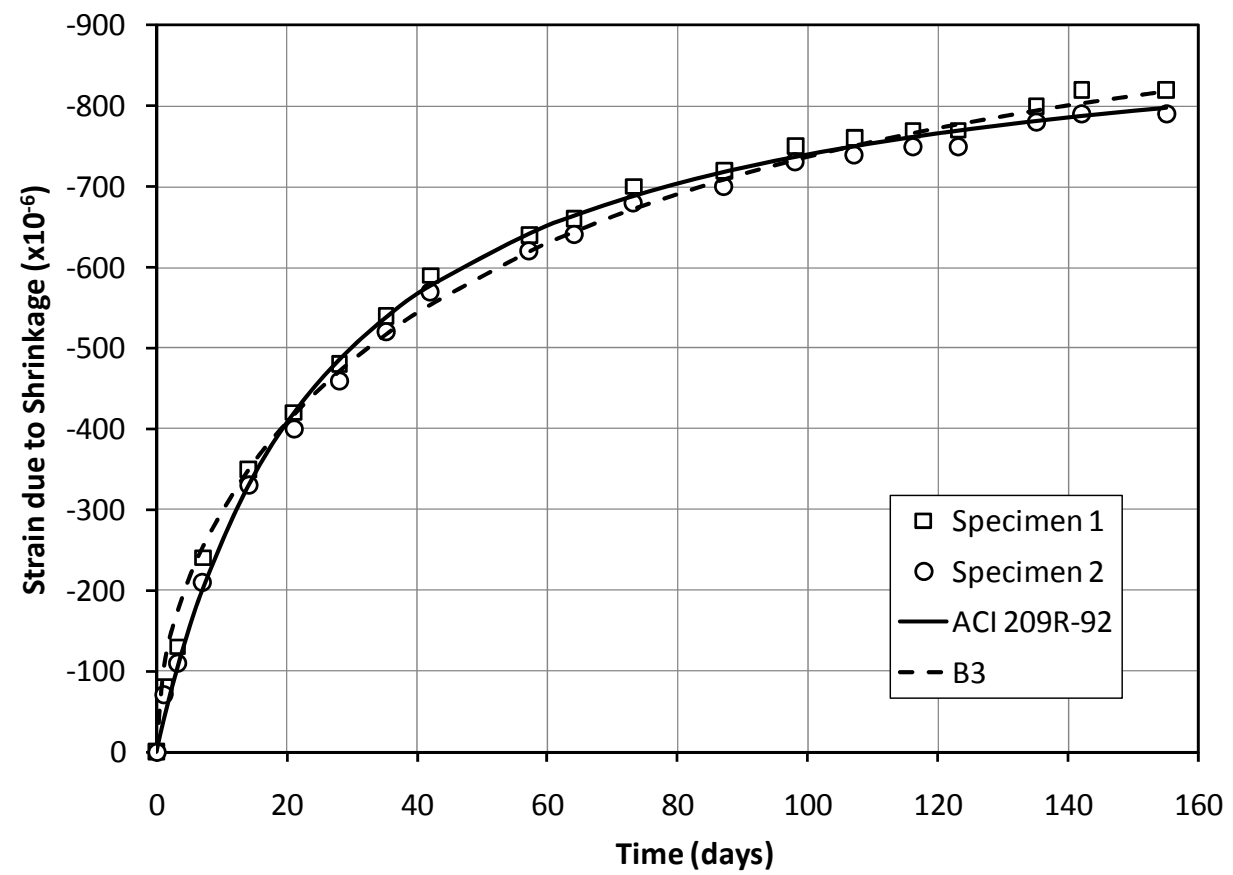

Figure C-15: Shrinkage Specimen Data w/ Prediction Curves (RS60-100)

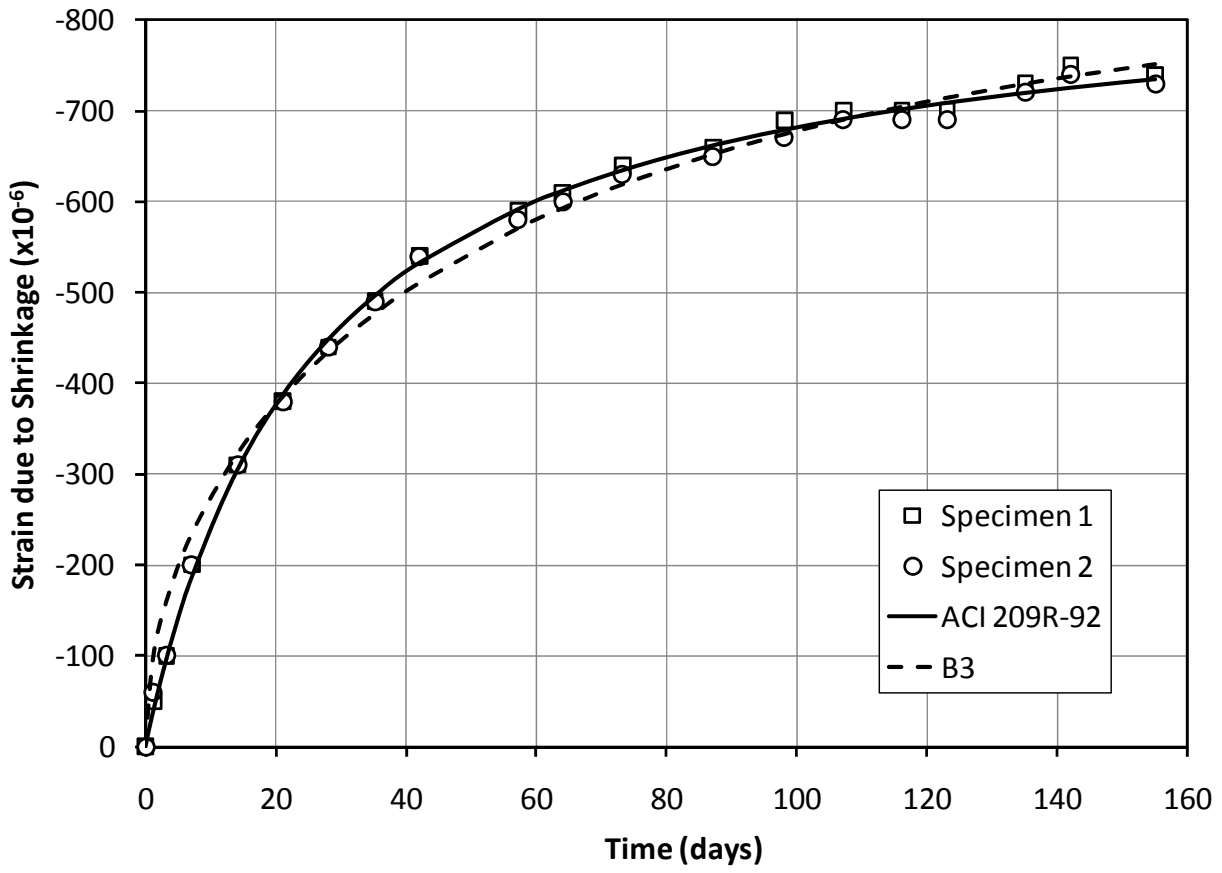

Figure C-16: Shrinkage Specimen Data w/ Prediction Curves (RD60-100) 


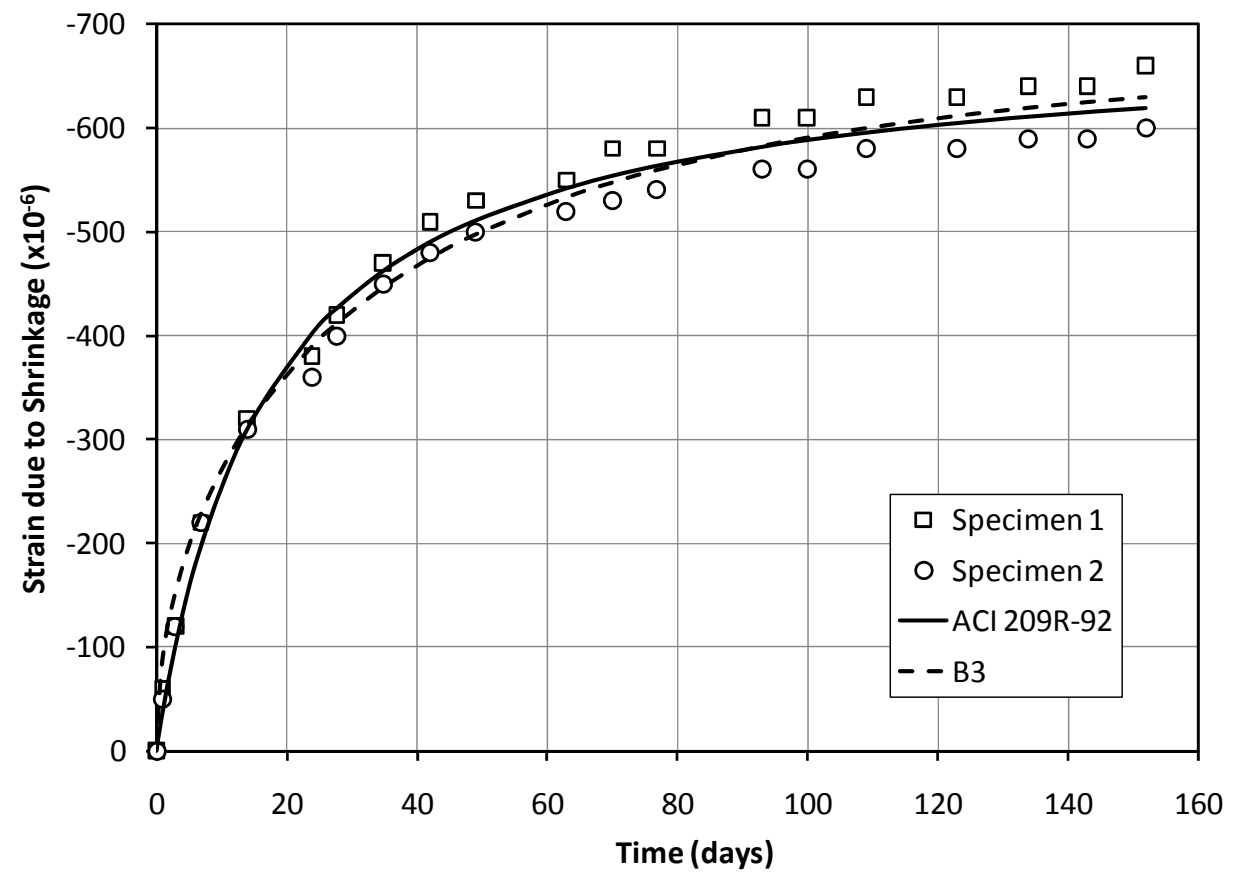

Figure C-17: Shrinkage Specimen Data w/ Prediction Curves (N30)

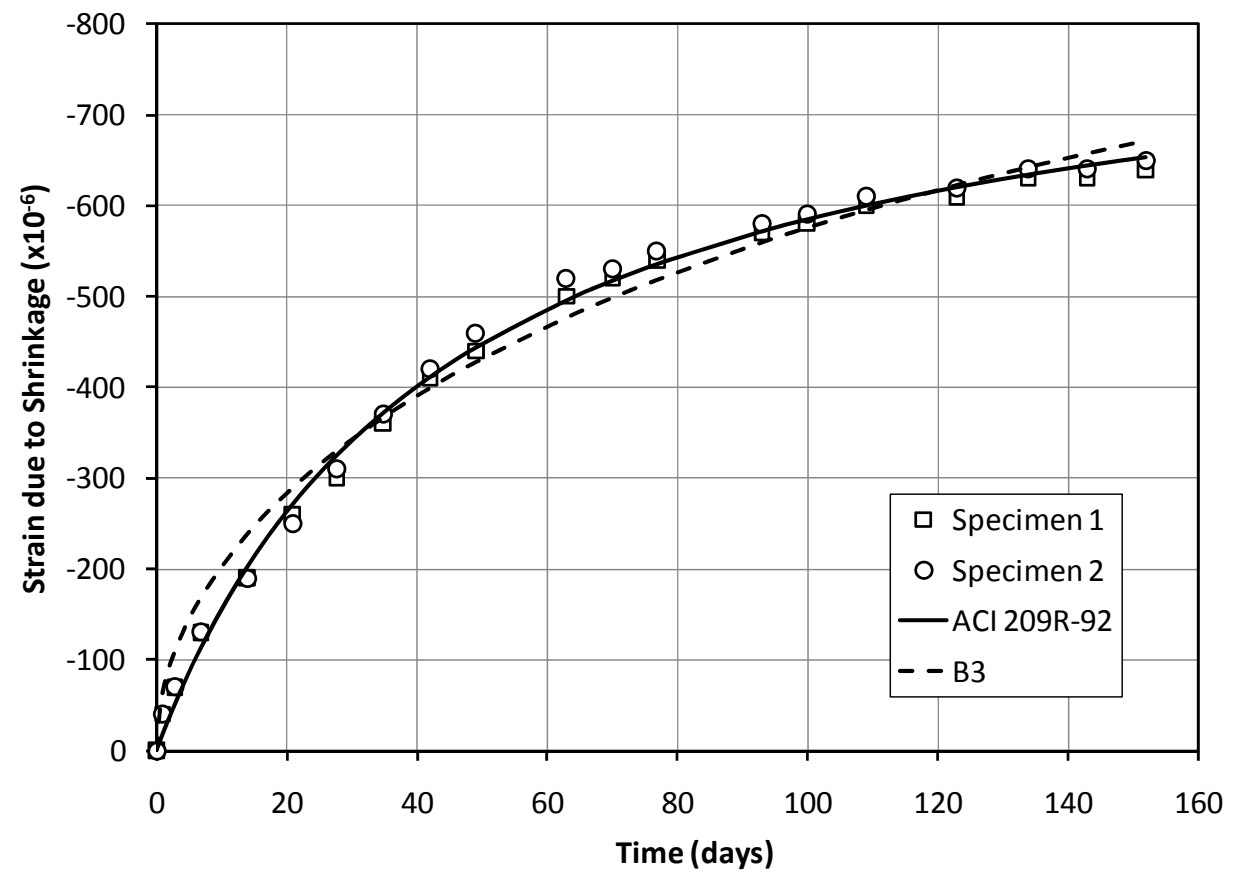

Figure C-18: Shrinkage Specimen Data w/ Prediction Curves (R30-100) 


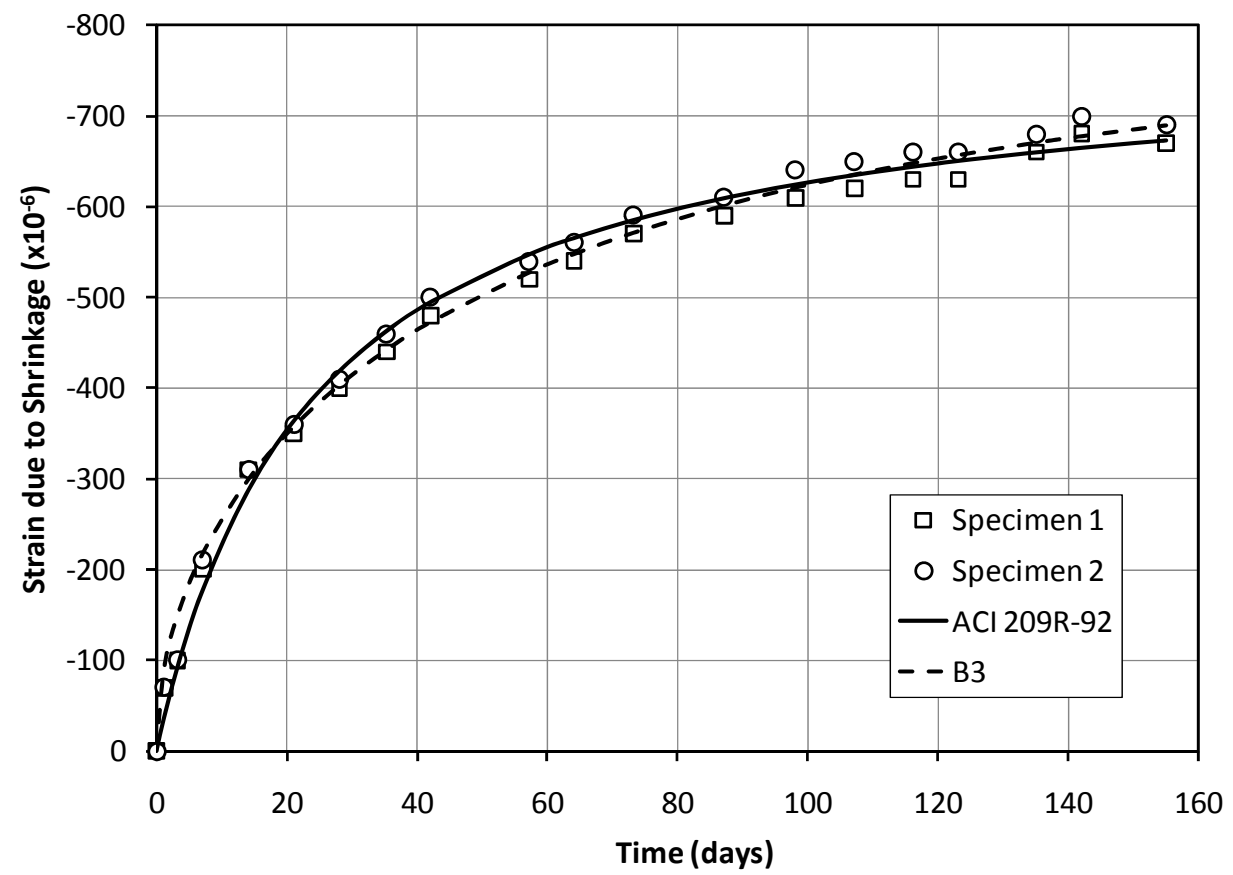

Figure C-19: Shrinkage Specimen Data w/ Prediction Curves (RS30-100)

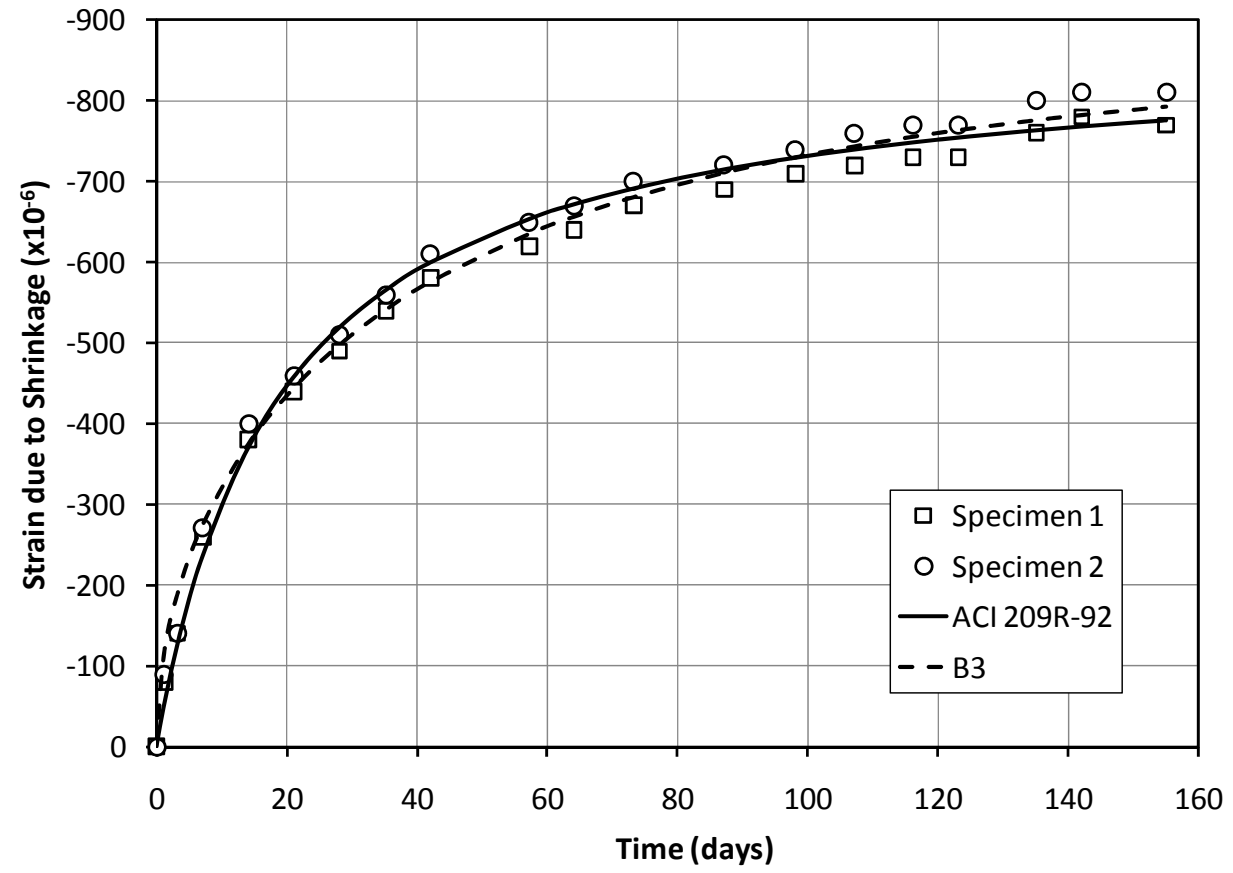

Figure C-20: Shrinkage Specimen Data w/ Prediction Curves (RD30-100) 